UNIVERSIDADE DE SÃO PAULO

FACULDADE DE FILOSOFIA, LETRAS E CIÊNCIAS HUMANAS

DEPARTAMENTO DE GEOGRAFIA

PROGRAMA DE PÓS-GRADUAÇÃO EM GEOGRAFIA HUMANA

\title{
Divisão do Trabalho e
}

\section{Circuitos da Economia Urbana em Londrina - PR.}

Tese apresentada ao Programa de PósGraduação em Geografia Humana do Departamento de Geografia da Faculdade de Filosofia Letras e Ciências Humanas da Universidade de São Paulo para obtenção do título de Doutor em Geografia.

Área de concentração: Geografia Humana.

Orientadora: Prof.a Dra. Maria Laura Silveira. 


\section{DEDICATÓRIA}

Meus pais, Luís e Maria Francisca, deram-me a vida e ensinaram-me que lutar por ela e desejá-la são tão essenciais quanto respirar. Minha companheira Lilian Deróbio me apoiou e incentivou a enfrentar os desafios e reveses e comemorou comigo a generosidade da vida. A eles dedico esse trabalho. 


\section{AGRADECIMENTOS}

À Prof.a Dra. Maria Laura Silveira, que, durante os anos de convivência, muito contribuiu para meu amadurecimento intelectual e profissional com a ética, paciência e generosidade que caracterizam sua conduta profissional.

Ao Departamento de Geociências da Universidade Estadual de Londrina pelo apoio material e acadêmico durante o período de elaboração da tese.

Ao Programa de Pós-Graduação do Departamento de Geografia da Universidade de São Paulo pela oportunidade de realizar o curso de Doutorado.

Ao Prof. Dr. Elvio Martins Rodrigues pelas discussões no Grupo "Geografias do Contemporâneo" e pelas sugestões e críticas que pautaram a elaboração da Tese.

Aos colegas do Grupo "Geografias do Contemporâneo" por compartilharem leituras e experiências de trabalho acadêmico.

À grande amiga, Prof.a Dra. Ângela Katuta, pelos longos diálogos e ricas sugestões que muito ajudaram na elaboração da Tese.

Aos alunos Pedro, Guilherme, Igor, Juliana, Raquel e Sílvia, do curso de Geografia da UEL, que me ajudaram em diferentes momentos do trabalho de campo. 
OLIVEIRA, Edilson Luis de. Divisão do trabalho e circuitos da economia urbana em Londrina - PR. 2009. 338 f. Tese (Doutorado) Faculdade de Filosofia, Letras e Ciências Humanas, Universidade de São Paulo, São Paulo, 2009.

\section{RESUMO}

O objetivo central desta tese é analisar as transformações da economia urbana londrinense, particularmente de seu circuito inferior, à luz das variáveis que caracterizam o período atual, o período da globalização. Para tanto, dividimos a presente tese em duas partes. Na primeira, analisamos as sucessivas modernizações efetivadas em Londrina e as transformações na divisão territorial do trabalho que redundaram em diferentes especializações produtivas a partir da década de 1930 . Na segunda parte, analisamos a organização e o funcionamento de três atividades do circuito inferior da economia urbana: o pequeno comércio estabelecido no Camelódromo de Londrina, o serviço de Mototáxi e o serviço de Entregas Urbanas realizado por motoboys.

As conclusões a que chegamos revelam que, no período atual, a dinâmica do meio construído é um dado fundamental da economia urbana. Os fluxos que se efetivam a partir das atividades investigadas envolvem a redefinição dos papéis de intermediação que caracterizam Londrina como uma cidade média da Região Concentrada.

O circuito inferior atual apresenta diferenças importantes em relação àquele que se formou em Londrina ao longo dos anos 1970, tais como: as trajetórias dos trabalhadores no mercado de trabalho, a importância dos processos migratórios do campo para a cidade, as escalas de ação de cada circuito, suas formas de integração, entre outras. Estas diferenças são conseqüências das modernizações na economia urbana inerentes à expansão e difusão espacial do meio técnico-científico-informacional.

Palavras-chave: Economia urbana. Londrina. Meio técnico-cientificoinformacional.Divisão Territorial do Trabalho. Circuito Inferior. 
OLIVEIRA, Edilson Luis de. Labor division and circuits of urban economy in Londrina - PR. 2009. 338 f. Tese (Doutorado) - Faculdade de Filosofia, Letras e Ciências Humanas, Universidade de São Paulo, São Paulo, 2009.

\begin{abstract}
The central objective of this thesis is to analyze the transformation of the urban economy Londrina, particularly to its lower circuit in the light of variables that characterize the current period, the period of globalization. To this end, we have divided this thesis into two parts. At first, we analyze the successive modernization that happened in Londrina and the changes in the territorial division of labor that resulted in different productive specializations from the 1930s. In the second part, we analyze the organization and operation of three activities of lower circuit of the urban economy: the small business set out in Camelódromo of Londrina, the Moto Táxi service and service performed by Urban Delivery couriers.

The conclusions reached show that in the current period, the dynamics of the built environment is a fundamental element of the urban economy.

The flows that happen based on the investigated activities involve the redefining of intermediation roles that featuring Londrina city as medium town in the Concentrated Region of Brasil

The contemporaneous lower circuit shows major differences when it compares with the lower circuit formed in Londrina in the 1970s, like these: the trajectories of workers in the labor market, the importance of migration from the countryside to the city, the scales of action of upper and lower circuits, its forms of integration, among others. These differences are consequences of modernizations in the urban economy. Besides, they're inherent at expansion and spatial diffusion of technicoscientific-informational milieu.
\end{abstract}

Keywords: Urban Economy. Londrina. Technico-scientific-informational Milieu. Lower Circuit. Territorial Labor's Division. Upper Circuit. Lower Circuit. 


\section{Lista de Gráficos}

Gráfico 1 - Londrina: evolução das populações urbana e rural, 1950 a 1970 53

Gráfico 2 - Londrina: evolução do n. ${ }^{\circ}$ de estabelecimentos da Indústria, Comércio e Serviços, 1950 a 1970. 54

Gráfico 3 - Londrina: PEA por setores de atividade, 1960 a 1970. 55

Gráfico 4 - Londrina: evolução da telefonia fixa, 1960 a 1990. 66

Gráfico 5 - Microrregião Homogênea de Londrina: evolução da área colhida das lavouras temporárias, 1970 a 1980. 70

Gráfico 6 - Londrina: evolução das populações urbana e rural, 1960 a 2000. 78

Gráfico 7 - Londrina: evolução da PEA por setores de atividade, 1960 a 2000 81

Gráfico 8 - Londrina: crescimento relativo da população urbana e da PEA em atividades urbanas, 1970 a 2000.

Gráfico 9 - Londrina: evolução dos estratos de renda, 1970 a 2000

Gráfico 10 - Londrina: n. ${ }^{\circ}$ de estabelecimentos da indústria de transformação, 1960 a 1985 96

Gráfico 11 - Londrina: pessoal ocupado na indústria de transformação, 1960 a 1985

Gráfico 12 - Londrina: atividades de serviço selecionadas, 1974 a 1993

Gráfico 13 - Brasil: índice médio de desemprego total em seis Regiões Metropolitanas, 1998 a 2008

Gráfico 14 - Brasil: percentual de municípios com presença do serviço de Moto Táxi por Macrorregião, 2005 e 2008

Gráfico 15 - Brasil: variação do rendimento médio real dos assalariados em seis Regiões Metropolitanas, 1998 a 2008.

Gráfico 16 - Brasil: pessoas em domicílios abaixo da linha da pobreza, 1977 a 2007

Gráfico 17 - Londrina: equipamento domiciliares nas residências dos trabalhadores do circuito inferior, 2008

Gráfico 18 - Londrina: rendimentos líquidos dos trabalhadores nas três atividades, 2008

Gráfico 19 - Grau de escolaridade dos trabalhadores do Camelódromo

Gráfico 20 - Grau de escolaridade dos proprietários dos mototaxistas

Gráfico 21 - Grau de escolaridade dos motoboys

Gráfico 22 - Londrina: mototaxistas segundo tipos de corridas 
Lista de Figuras

Figura 1 - Estrada Vicinal no Distrito da Warta, $1957 \quad$........................ 30

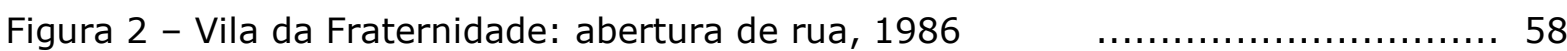

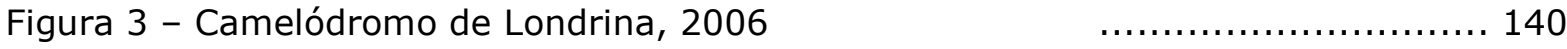

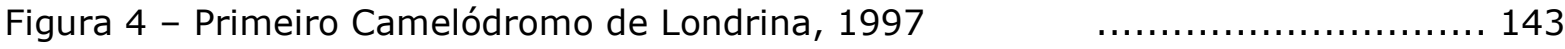

Figura 5 - Primeiro Camelódromo de Londrina, $1997 \quad$.......................... 143 


\section{Lista de Mapas}

Mapa 1 - Norte do Paraná: áreas de colonização dirigida e não dirigida 17

Mapa 2 - Paraná: situação dos terás adquiridas pela CTNP e sistema viário, 1957

Mapa 3 - Rede de estradas vicinais do entorno regional de Londrina, 1938 30

Mapa 4 - Londrina: croquis da planta inicial da cidade 36

Mapa 5 - Londrina: localização de algumas Vilas, 1957

Mapa 6 - Aglomeração urbana não-metropolitana de Londrina: evolução da população urbana, 1960 - 1991

Mapa 7 - Norte do Paraná: áreas com ganhos e perdas de população, 1970 a 1991

Mapa 8 - Londrina: distribuição das áreas industriais - CILOS 89

Mapa 9 - Brasil: distribuição do Serviço de Moto Táxi por Região, 2005/08

Mapa 10 - Londrina: distribuição das Centrais de Moto Táxi, 2008

Mapa 11 - Londrina: distribuição das Centrais de Moto Táxi e setores censitários com mais de $20 \%$ de responsáveis por domicílios com rendimentos de até 2 sal. mínimos, 2008.

Mapa 12 - Londrina: porte das centrais por n. ${ }^{\circ}$ de mototaxistas, 2008.

Mapa 13 - Londrina: distribuição dos trabalhadores do Camelódromo, 2008 205

Mapa 14 - Londrina: distribuição dos mototaxistas, 2008

Mapa 15 - Londrina: distribuição dos motoboys, 2008

Mapa 16 - Londrina: distribuição dos trabalhadores do circuito inferior e setores censitários com mais de $20 \%$ de responsáveis por domicílio com rendimento de até 2 salários mínimos, 2008.

Mapa 17 - Londrina distancia relativa das Centrais ao Centro Principal.

Mapa 18 - Fluxos de mercadorias vendidas no Camelódromo de Londrina, 2008

Mapa 19 - Paraná: municípios de procedência dos compradores de mercadorias do Camelódromo de Londrina, 2008.

Mapa 20 - Londrina: representação esquemática dos fluxos principais e secundários do Moto Táxi, 2008.

Mapa 21 - Londrina: representação esquemática dos fluxos principais das Entregas Urbanas, 2008.

Mapa 22 - Norte do Paraná: municípios que recebem corridas dos motoboys pelo menos uma vez por semana, 2008.

Mapa 23 - Norte do Paraná: municípios que recebem corridas dos mototaxistas pelo menos uma vez por semana, 2008. 


\section{Lista de Tabelas}

Tabela 1 - Principais Agroindústrias da região de Londrina, 2007.

Tabela 2 - Caracterização das três maiores empresas de Entregas Urbanas, 2008,

Tabela 3 - Trabalhadores (as) do circuito inferior em Londrina: caracterização quanto ao gênero, 2008.

Tabela 4 - Trabalhadores (as) do circuito inferior em Londrina: caracterização quanto as faixas etárias, 2008.

Tabela 5 - Migrantes, não-migrantes no circ. inferior - Londrina, 2008.

Tabela 6 - Participação dos trabalhadores autônomos no mercado formal de trabalho, 2008.

Tabela 7 - Tempo de trabalho na atividade por conta própria, 2008.

Tabela 8 - Mototaxistas: funções anteriores e escolaridade, 2008.

Tabela 9 - Proprietários do Camelódromo: funções anteriores e grau de Escolaridade, 2008.

Tabela 10 - Motoboys: funções anteriores e escolaridade, 2008.

Tabela 11 - Camelódromo: origem das mercadorias, 2008.

Tabela 12 - Tipos de empresas que solicitam o serviço de Mota Táxi, 2008.

Tabela 13 - Motoboys que realizam entregas em outros municíp., 2008.

Tabela 14 - Municípios que recebem entregas por Motoboys de Londrina, 2008.

Tabela 15 - Propriedade da motocicleta utilizada nas entregas Urbanas, 2008.

Tabela 16 - Valor da prestação dos financiamentos, 2008. 


\section{SUMÁRIO}

Introdução. 1

\section{PARTE I}

ECONOMIA URBANA E DIVISÃO DO TRABALHO CAPÍTULO 1

A formação de Londrina e o berço rural de sua economia urbana. 14

1.1 - A formação de Londrina e de seu entorno regional ............................. 16 1.1.1 - A importância do conhecimento prévio na escolha das áreas adquiridas pela Companhia de Terras 20 1.1.2 - Estratégias, seletividade e adequação às conjunturas na produção do arranjo espacial de Londrina e seu entorno regional .......................................... 25 1.1.3 - A produção da cidade e da situação de Londrina no contexto regional norte-

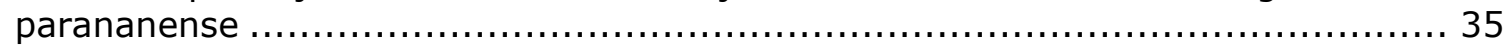

1.2 - A Cafeicultura e a economia urbana em Londrina ............................... 41

1.2.1 - A Cafeicultura e o contexto da formação do circuito superior embrionário . 43

1.2.2 - A Cafeicultura e o contexto da formação do circuito inferior embrionário... 53

1.2.3 - Os elementos dispersos de um circuito inferior embrionário 56

\section{CAPÍtULO 2}

As transformações da economia urbana de Londrina no período técnicocientífico.

2.1 - As condições para o pleno desenvolvimento dos circuitos da economia urbana 61 2.1.1 - A primeira fase de difusão do meio técnico-científico-informacional no Paraná e em Londrina............................................................... 62 2.1.2 - As novas especializações produtivas: a expansão das lavouras temporárias

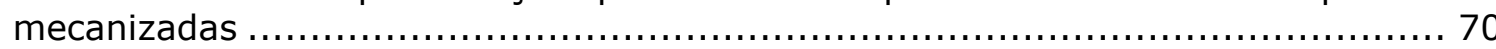

2.1.3 - As novas especializações produtivas: agroindústrias e cooperativas .......... 73

2.1.5 - A rápida expansão e a diversificação do meio construído...................... 85

2.2 - Os circuitos da economia urbana em Londrina no período técnico-científico..... 94

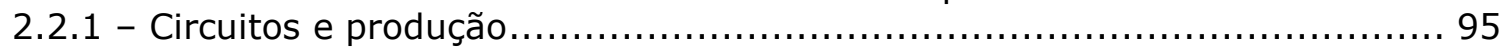

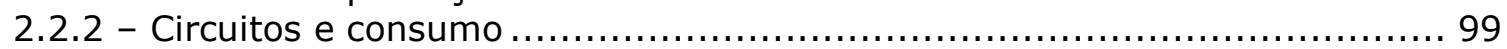

\section{CAPÍTULO 3}

O período atual e as transformações na dinâmica dos circuitos. 108

3.1 - Uma breve caracterização do período atual 108

3.2 - A expansão do meio técnico-científico-informacional e a contextualização de Londrina como cidade média

3.3 - As modernizações atuais e as repercussões sobre o circuito superior da economia urbana

3.4 - O período atual e o circuito inferior da economia urbana....

3.4.1 - Algumas considerações sobre o período atual: desemprego, pobreza e rupturas 


\section{PARTE II}

A REESTRUTURAÇÃO DOS CIRCUITOS

\section{CAPÍTULO 4}

A racionalidade do circuito inferior no período atual ............................ 130

4.1 - Racionalidade hegemônica e circuito inferior..................................... 130

4.2 - A caracterização do Camelódromo de Londrina .................................. 140

4.2.1 - A gênese do Camelódromo de Londrina ...................................... 143

4.3 - A gênese do Moto Táxi ....................................................... 158

4.3.1 - A localização, distribuição e caracterização das Centrais de Moto Táxi .....166

4.4 - Entregas Urbanas: empresas e motoboys...................................... 173

\section{CAPÍTULO 5}

Trabalho, pobreza e circuito inferior no período atual

5.1 - Transformações no mundo do trabalho e a dinâmica do empobrecimento relativo

5.2 - Formas de resistência e enfrentamento da pobreza no período atual: a

diversidade de abordagens

5.3 - A caracterização dos trabalhadores do circuito inferior da economia urbana em Londrina

5.3.1 - As características de gênero, faixas etárias e estado civil ...................203

5.3.2 - Localização, distribuição e caracterização dos domicílios ........................205

5.3 .3 - Renda mensal, jornadas e vínculos de trabalho................................213

5.4 - As razões da entrada e da permanência dos trabalhadores nas atividades do circuito inferior exercidas por conta própria ............................................. 217

5.5 - Trajetórias dos trabalhadores do circuito inferior no mercado de trabalho e escolaridade

\section{CAPÍTULO 6}

O circuito inferior na divisão do trabalho: aceleração contemporânea, horizontalidade e articulação de escalas .................................................. 229

6.1 - A aceleração contemporânea e a circulação de mercadorias e pessoas em

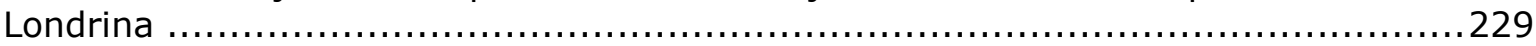

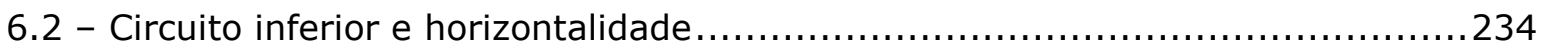

6.2.1 - O Camelódromo: complementaridade e cooperação ...........................236

6.2.2 - O Moto Táxi: fluxos intraurbanos, constrangimentos do meio construído e formas de cooperação ............................................................... 242

6.2.3 - Motoboys e entregas urbanas: complementaridade e fluxos intraurbanos 251

6.3 - As escalas da ação no circuito inferior...........................................256

6.3.1 - O Camelódromo e a articulação de diferentes escalas .........................257

6.3.2 - Mototaxistas e motoboys: horizontalidades e verticalidades na circulação de

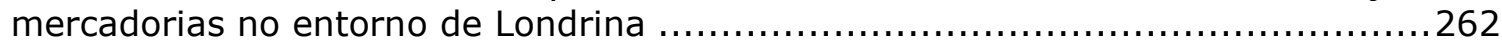




\section{Introdução}

O objetivo central dessa Tese é analisar as transformações da economia urbana londrinense, particularmente de seu circuito inferior, à luz das variáveis que caracterizam o período técnico-científicoinformacional.

Um período é um instrumento de análise para geografia. A periodização resulta da identificação de variáveis e eventos cujo significado e duração podem ser demarcados, interpretados e espacialmente contextualizados pelas relações entre processos, funções e formas diversas, incluindo as formas espaciais (SANTOS, 1992).

A integração entre variáveis, eventos, processos, funções e formas estabelece entre eles diversos graus de coerência e coesão que auxiliam na definição da periodização. A cada novo período a coerência e a coesão anteriores podem se desmanchar (SILVEIRA, 2004). Por outro lado, a situação atual depende de influências e condições herdadas dos períodos precedentes.

O período atual, período técnico-científico-informacional, é marcado por variáveis como a informação e suas várias manifestações (as consultorias, as cotações das bolsas, a propaganda, as possibilidades presentes nos lugares, entre outras), a crescente aproximação entre ciência e técnica, a constituição de redes de diversos tipos que influenciam as formas de sociabilidade e de articulação entre os lugares.

Essas variáveis combinam-se a eventos como inovações técnicas e organizacionais que, por sua vez, incidem sobre a qualidade e a quantidade dos empregos e ocupações, sobre o ritmo e as escalas da circulação, da produção e do consumo, enfim, sobre o modo de vida, particularmente, o modo de vida urbano.

As maneiras como esse conjunto de variáveis, eventos e processos se combinam nos lugares fazem com que o período atual também se caracterize pela coexistência entre novas e velhas formas de estabelecer a coerência e a subordinação entre os circuitos da economia 
urbana. Os circuitos se reestruturam, adquirem novas feições, ensejam a realização de novos processos e a perpetuação de outros, dão existência a novas formas e fazem reviver formas consideradas superadas.

A sucessão dos períodos promove a superposição de diferentes divisões do trabalho e, por meio delas, as influências e condicionamentos de períodos anteriores incidem sobre o período atual. Os circuitos são expressões da superposição das divisões do trabalho nos lugares.

A formação e a reestruturação dos circuitos se fazem em sintonia com as transformações na divisão territorial do trabalho. No Norte do Paraná a dinâmica e a sucessão da inserção regional na divisão do trabalho na escala nacional e na escala mundial foram decisivas para a formação e a transformação da economia urbana londrinense. Ao longo da pesquisa procuramos compreender o modo como as transformações da cidade e do território ligadas às diversas divisões do trabalho se combinaram para criar as condições para a formação e reestruturação dos circuitos e de seu entrelaçamento.

$\mathrm{Na}$ primeira parte do trabalho a divisão territorial do trabalho é uma categoria central para a organização da periodização adotada e para a análise da formação dos circuitos em Londrina. Na segunda parte a análise da coerência e das formas de entrelaçamento, competição e subordinação entre os circuitos é o objetivo que perseguimos.

Como manifestações da superposição de diferentes divisões do trabalho em Londrina, as quais são viabilizadas pela diversidade, fragmentação e articulação do meio construído, os circuitos se revelam, eles próprios, expressão fiel dos conflitos e contradições que marcam o cotidiano nas cidades médias da Região Concentrada.

O tema dos circuitos da economia urbana se reveste de especial importância nesse momento em que, as conseqüências do projeto neoliberal dos anos 1990 estão impressas na paisagem urbana com a multiplicação dos trabalhadores ditos "informais", com o recrudescimento 
das dívidas sociais e a produção de novas formas de empobrecimento e de instabilidade.

O debate sobre a segmentação da economia urbana em países subdesenvolvidos não é novo, mas nem por isso deixou de ser atual. Segundo Milton Santos (1979) a formação dos circuitos da economia urbana é inerente aos processos de modernização desencadeados nos países subdesenvolvidos após a Segunda Grande Guerra. As condições geográficas, econômicas e políticas próprias às formas da divisão de trabalho, social e territorial, nos países subdesenvolvidos foram transformadas de maneira específica pelos processos de modernização. Como conseqüência o processo de urbanização se acelera, reforçando a concentração de renda e gerando a segmentação da produção e do consumo, que está na base da existência dos circuitos. A presença dessa segmentação é estrutural e funcional ao desenvolvimento do próprio capitalismo nos países do Terceiro Mundo.

A existência dos circuitos da economia urbana está relacionada com a especificidade do espaço nos países subdesenvolvidos. Essa especificidade deriva do fato de que os elementos que constituem o espaço são os mesmos que estão presentes em outros países, mas o modo como se combinam nos países subdesenvolvidos é diferente (SANTOS, 1979, p.15). Para explicitar essa especificidade Milton Santos insiste em quatro pontos fundamentais.

O primeiro deles é que, os países subdesenvolvidos se "organizam e reorganizam em função de interesses distantes, e mais freqüentemente na escala mundial" (SANTOS, 1979, p.15). Essas forças de transformação emanadas do exterior atingiam o território em pontos específicos e não se difundiam pelo território com facilidade, permanecendo relativamente concentradas.

O segundo ponto é uma decorrência direta do primeiro, uma vez que a seletividade peculiar aos processos de modernização tinha como resultante o fato de que "as variáveis modernas não são acolhidas todas ao mesmo tempo nem têm a mesma direção" (SANTOS, 1979, p.15), o 
que tornava o espaço nos países subdesenvolvidos, instável e descontínuo, do ponto de vista da modernização. Produção moderna e consumos modernos, por exemplo, difundiram-se de forma desigual e combinada pelo território brasileiro afetando a formação do sistema urbano, especialmente a configuração de suas Metrópoles.

O terceiro ponto indica a complexidade que se forma nos lugares graças à multipolarização a que estão submetidos. Nas palavras do autor temos o seguinte: "o espaço dos países subdesenvolvidos é igualmente multipolarizado, ou seja, é submetido e pressionado por múltiplas influências e polarizações oriundas de diferentes níveis de decisão" (SANTOS, 1979, p.15).

O quarto ponto dizia respeito às enormes disparidades de renda e à sua expressão regional diferenciada, que nos países subdesenvolvidos tinha implicações fortes sobre o acesso dos indivíduos a um grande número de bens e serviços. Trazendo a discussão da concentração de renda para um plano geográfico Milton Santos apontava que "O nível de renda também é função da localização do indivíduo, o qual determina, por sua vez, a situação de cada um como produtor e consumidor". (SANTOS, 1979, p.15)

No contexto da teoria dos circuitos da economia urbana a afirmação da especificidade do espaço dos países subdesenvolvidos revela com clareza a necessidade de considerar as múltiplas escalas envolvidas na produção dos lugares, dialogando com as teorias sobre a dependência ${ }^{1}$, de maneira que o componente espacial, particularmente, o processo de urbanização, também fosse considerado.

\footnotetext{
${ }^{1}$ Há diferentes enfoques e argumentações sobre a questão da dependência na América Latina. Alguns autores discutiram o tema, compondo um amplo debate que se tornou emblemático nos anos 1960 e 1970 em relação às alternativas para o desenvolvimento econômico na região. Podemos citar a título de exemplo:

- CARDOSO, Fernando H. e FALETO, Enzo. Dependência e desenvolvimento na América Latina. Rio de Janeiro: Zahar, 1973.

- $\quad$ FURTAdO, Celso. O mito do desenvolvimento econômico. Rio de Janeiro: Paz e Terra, 1974.

- GUNDER FRANK, André. Acumulação dependente e subdesenvolvimento. São Paulo: Brasiliense, 1980.

- SANTOS, Theotonio dos. A Teoria da Dependência: balanço e perspectivas. Rio de Janeiro: Civilização Brasileira, 2000.
} 
A teoria dos circuitos também propõe uma crítica frontal ao dualismo, concepção muito difundida nos anos 1960 e 1970 acerca da economia, da sociedade e da urbanização dos países subdesenvolvidos.

Milton Santos afirmava que o principal problema da concepção dualista presente em diversas teorias da modernização ${ }^{2}$ era sua forma parcial e fragmentada de abordar a realidade. Privilegiando as formas modernas de produção, e tratando as atividades não-modernas como resíduos destinados a simplesmente desaparecer, essas teorias concebiam o processo de modernização de forma linear e análoga a processos naturais nos quais o amadurecimento varreria as formas tradicionais de produção e consumo da cena econômica. Tratava-se apenas de uma questão de tempo e de atraso histórico.

A idéia central das concepções dualistas, a de que entre atividades modernas e tradicionais haveria situações de conflito e de confronto, era explicitamente considerada pelo autor como equivocada, em face das condições históricas e geográficas dos anos 1970. De uma maneira taxativa, Santos (1979, p. 43) afirmou: "Assim não há dualismo: os dois circuitos têm a mesma origem, o mesmo conjunto de causas e são interligados".

É oportuno retomar esses aspectos atinentes à teoria dos circuitos tendo em vista que as concepções dualistas, apesar de seu anacronismo e equívocos teóricos, costumam reaparecer de forma subreptícia nos debates atuais sobre a formalização dos informais, sobre empreendedorismo e outros dessa natureza. Tidas como práticas de "boa governança" as formas de controle e fiscalização draconianas sobre as atividades classificadas como informais são requisitos para que esta ou aquela cidade possa se inserir em circuitos globais de acumulação de capital, habilitando-se assim a receber investimentos e outras concessões.

\footnotetext{
${ }^{2}$ Dentre os autores que defendiam esse ponto de vista temos: GERMANI, Gino. Política y Sociedad en una Época de Transición. Buenos Aires: Paidos, 1962 e HAGEN, Everett E. Theory of Social Change: how economic growth begins. Homewood (Illinois): Dorsey Press, 1962.
} 
Em resumo, as atividades informais são definidas e tratadas como signos do atraso que, como tais, devem ser modernizadas.

A teoria dos circuitos indica que a cidade em países subdesenvolvidos como o Brasil deve ser entendida como uma totalidade resultante da articulação de dois subsistemas: o circuito superior e o inferior, cuja existência e funcionamento estão diretamente relacionados com o modo particular de realização do consumo e da produção comandados pela grande indústria. Dessa forma, fica patente a contemporaneidade do fenômeno dos dois circuitos em relação ao período da modernização tecnológica ${ }^{3}$, que se caracteriza pelo peso e importância crescentes da ciência e da tecnologia cuja produção é comandada por gigantescas empresas multinacionais e pelo Estado, pela internacionalização mais profunda da economia e por uma característica que, para o autor, tem grande importância para a especificidade do ordenamento espacial dos países subdesenvolvidos: a difusão em escala mundial da informação e do consumo.

Esses argumentos deixam claro que não é possível falar em circuitos da economia urbana para explicar a urbanização brasileira, por exemplo, no século $\mathrm{XIX}$ ou no início do $\mathrm{XX}$, pois as relações próprias à disseminação do consumo e da informação, à integração do território nacional por meio de uma intensa circulação de pessoas, mercadorias e informações não se fazia presente.

Milton Santos (1979, p.67 a 94) caracteriza o circuito superior, identificando as atividades que o integram: o comércio e a indústria urbanos e modernos, o comércio de importação e exportação, a indústria de exportação, os bancos, atacadistas e transportadores. Identifica também os consumidores, ou o público, ligado a esse circuito.

\footnotetext{
3 "O período atual diferencia-se nitidamente dos precedentes por sua capacidade nova de revolucionarização. Pela primeira vez na história dos países subdesenvolvidos, duas variáveis elaboradas no centro do sistema encontram uma difusão generalizada nos países periféricos. Trata-se da informação e do consumo - a primeira estando a serviço do segundo - cuja generalização constitui um fator fundamental de transformação da economia, da sociedade e da organização do espaço"(SANTOS 1979, p. 28).
} 
Como nos diz o próprio autor, uma característica comum a todas essas atividades é que elas são "capital intensivas", ou seja, têm na tecnologia, na organização burocrática e no acesso ao crédito bancário sua base comum. Destacou ainda dois outros aspectos do circuito superior: a forte presença de oligopólios, a exemplo de algumas empresas multinacionais, e o favorecimento por parte do Estado, particularmente na oferta de infraestruturas, subsídios fiscais, reserva de mercados, etc. Tais aspectos são definidores da relação entre as atividades dos dois circuitos e de cada um dos circuitos com o território.

Por sua vez o circuito inferior é composto pelas atividades não-modernas, "intensivas em trabalho" e de pequeno porte, o que abrange um amplo leque: comércio varejista, artesãos, pequenas fabricações, serviços, especialmente o trabalho doméstico, transportes autônomos, entre outros (SANTOS, 1979, p. 147 a 203). Esse circuito se relaciona com as condições de vida da população pobre em meio à economia urbana moderna ${ }^{4}$

A urbanização e a modernização da economia produzem as condições que permitem que o circuito inferior se instale. O circuito superior é uma conseqüência direta da modernização tecnológica e o circuito inferior, uma conseqüência indireta (SANTOS, 1979, p. 29). A concentração de pessoas pobres nas grandes cidades será criadora de uma demanda que o circuito superior, com sua lógica própria, não atenderá. Essa demanda será tanto por bens e serviços como por ocupação, se possível por empregos, por habitação, transporte, lazer, etc.

O circuito inferior que não se restringe ao setor terciário, com o qual costuma ser confundido, inclui também formas artesanais de produção. Seu fundamento principal, no entanto, é a associação entre concentração de renda, consumos modernos e a ausência total ou parcial de sistemas de proteção social. Frente a essas formas de escassez que

\footnotetext{
4 "As condições de evolução da economia moderna e o enorme peso de uma população urbana com baixo nível de vida, que não para de aumentar com a chegada maciça de migrantes vindos do campo, acarretam a existência, ao lado do circuito moderno, de um circuito econômico não-moderno, que compreende a pequena produção manufatureira, freqüentemente artesanal, o pequeno comércio de uma multiplicidade de serviços de toda espécie.”(SANTOS, 1979, p. 155).
} 
penalizam os mais pobres o circuito inferior se constitui como uma forma de "perpetuar a pobreza" (SANTOS, 1979, p.203). Essa é a função que the cabe e que possibilita entender a racionalidade do circuito inferior nas cidades dos países do Terceiro Mundo.

A esses fundamentos soma-se o fato de que "o consumo crescente de produtos modernos por uma população pobre faz nascer uma série de novas atividades no circuito inferior." (SANTOS, 1979, p. 200).

Conclui-se, portanto, que a modernização do consumo se configura como uma força importante na definição e articulação entre os circuitos $^{5}$. Trazendo essa discussão para o presente Maria Laura Silveira (2004, 2009) considera que, dentre as variáveis que caracterizam o período atual ${ }^{6}$, estão: as finanças e a expansão do crédito e a intensificação do consumo que redundam em uma crescente exigência de fluidez territorial por parte dos atores hegemônicos, especialmente os que se organizam a partir da cidade e que repercutem sobre o cotidiano e o modo de vida urbano.

A intensificação do consumo e da circulação, em conjunção com outros processos inerentes ao período atual como o desemprego crônico e as formas renovadas de produção de pobreza urbana, incidem sobre a dinâmica dos circuitos, especialmente do circuito inferior. Essa é a base sobre a qual se multiplicam os trabalhadores com motocicletas, camelôs e camelódromos nas cidades brasileiras.

Em Londrina a recente recuperação do nível de emprego, ou seja, a modesta redução do desemprego no país, não parece ter sido suficiente para diminuir o contingente de trabalhadores submetidos a jornadas extenuantes de trabalho e que não contam com perspectivas

\footnotetext{
5 “O papel do consumo, à semelhança do terciário, não tem sido suficientemente considerado. P. Sweezy (1973, p.1) observa que n'O Capital Marx não analisou nem discutiu o papel do impacto tecnológico sobre o consumo e, através deste, sobre a acumulação e o desenvolvimento social. Há vinte anos do fim do século XIX, não podia Marx atribuir a essa variável o papel que ela assumiu com a revolução tecnológica e a rápida difusão de inovações. Por outro lado, a acumulação já não é exclusivamente dependente da produção, visto como o consumo se transformou num instrumento tão importante, que ele próprio acarreta um processo de produção que se torna posteriormente autônomo." (SANTOS, 1982, p.12)

${ }^{6} \mathrm{O}$ período atual é também um sinônimo para o processo de Globalização e/ou Mundialização da economia e da sociedade.
} 
futuras de participar de sistemas de previdência social. Esses trabalhadores atuam principalmente na esfera da circulação e do consumo e respondem pela ampliação do contingente de trabalhadores por conta própria e dos que estão inseridos em relações de trabalho enviesadas como os motoboys.

Observando a dinâmica dos circuitos da economia em Londrina notamos que a convergência entre a intensificação da circulação e do consumo, o desemprego e as baixas remunerações de muitos empregos formais aliados à fragmentação, os constrangimentos e a diversidade do meio construído propiciaram a reestruturação dos circuitos e a constituição de novas formas de entrelaçamento entre eles.

A relação entre a cidade e a divisão do trabalho concretizada nos circuitos, mediada pelas transformações no meio construído, foi uma escolha pertinente para a análise da economia urbana londrinense. A fragmentação e a diversidade do meio construído na cidade foram fundamentais para a compreensão da formação e funcionamento dos circuitos, particularmente do circuito inferior no período atual.

Para discutir essas questões realizamos o trabalho de campo a partir de 2007 e o concluímos em 2008. Como instrumento básico do levantamento de dados, elaboramos questionários que foram aplicados a diferentes categorias de trabalhadores envolvidos em atividades do circuito inferior e/ou circuito superior marginal:

a) proprietários e funcionários do Camelódromo de Londrina;

b) mototaxistas e centrais de Mototáxi;

c) empresas de entregas urbanas e motoboys.

A investigação pretendeu, sobretudo, caracterizar os trabalhadores e as atividades. A caracterização dos trabalhadores foi constituída por uma parte relativa aos dados pessoais, dados do domicílio do trabalhador e de sua relação com o mercado formal de trabalho em Londrina. Na parte referente às atividades, buscamos conhecer suas características básicas, tais como equipamentos utilizados, público 
atendido, faturamento, principais despesas, jornadas de trabalho, entre outras.

Quando a situação permitiu, os questionários foram acompanhados de conversas mais longas, na forma de entrevistas não estruturadas, as quais nos permitiram recolher muitas informações adicionais para caracterizar as atividades e os trabalhadores envolvidos.

Vale ressaltarmos que, particularmente no caso dos motoboys e mototaxistas, a realização das entrevistas e a aplicação dos questionários foram dificultadas pelo ritmo do trabalho dessas pessoas. Por vezes, os questionários foram interrompidos por chamadas e entregas e ficaram incompletos. Na medida do possível, retornávamos ao local para complementá-los e, quando isso não foi viável, substituímos o material inconcluso por novas conversas e novos questionários.

Ao todo, foram aplicados 207 questionários a trabalhadores das três atividades e mais 35 questionários às Centrais de Moto Táxi. Com alguns deles a aplicação do questionário se transformou em entrevista, na medida em que houve possibilidade de aprofundar a conversa e saber mais sobre o entrevistado. Entrevistamos também o presidente da ONG responsável pela gestão do Camelódromo em 2007, o Sr. Nilson Gonzáles e o Prefeito Nedson Micheleti, que esteve à frente do executivo municipal durante a constituição do Camelódromo e a regulamentação do serviço de Moto Táxi. Foram realizadas ainda três entrevistas específicas com proprietários das empresas Vai-Vem, Sol Motoboys e Terceiriza, as maiores empresas de entregas urbanas de Londrina em 2007/2008.

A definição do número de questionários obedeceu a critérios estatísticos e, para tanto, contamos com o auxílio do Departamento de Matemática Aplicada da Universidade Estadual de Londrina. O número mínimo de questionários para cada atividade, considerando uma margem de erro de $8 \%$, foi determinado da seguinte maneira: 80 questionários deveriam ser aplicados nos estabelecimentos do Camelódromo, 34 para as Centrais de Moto Táxi, 72 para os mototaxistas e 52 para os motoboys das empresas de entregas urbanas. 
Distribuímos os questionários aplicados aos mototaxistas e às Centrais de forma proporcional entre as zonas norte, sul, leste, oeste e central, o que resultou em um número maior de questionários e entrevistas na zona central da cidade. Procuramos também, fazer uma distribuição dos questionários aplicados no Camelódromo entre os dois pavimentos do edifício e, no caso dos motoboys, entre as três empresas que visitamos.

A partir dessas informações construímos um banco de dados que permitiu a elaboração das tabelas, mapas e argumentos que apresentamos ao longo do trabalho, sobretudo na segunda parte, onde analisamos o circuito inferior em Londrina no período atual. Por sua vez, a primeira parte trata da formação da economia urbana londrinense.

A primeira parte é composta de três capítulos. O capítulo 1 aborda a formação de Londrina e de seu entorno regional no contexto do empreendimento imobiliário efetivado pelo capital inglês no Norte do Paraná. Procuramos destacar a composição do arranjo espacial regional em função das conjunturas das décadas de 1930 e 1940, para discutirmos, em seguida, como a cafeicultura paranaense deu contornos específicos a esse arranjo e definiu a possibilidade de formação de uma economia urbana dinâmica em Londrina.

No capítulo 2, buscamos apresentar as transformações na divisão de trabalho na escala local a partir de meados dos anos 1960. Tais mudanças são decorrentes das modernizações que incidiram sobre a base urbana e regional construída pela cafeicultura no Norte do Paraná, as quais conformaram a emergência de novas especializações produtivas. Esse momento tem especial importância, pois se consolidaram as bases para o pleno desenvolvimento dos circuitos da economia urbana londrinense. Apresentamos o circuito superior e o circuito inferior a partir de atividades ligadas ao consumo e à produção que se desenvolveram na cidade em sintonia com as novas especializações produtivas e a dinâmica do meio construído. 
No capítulo 3, discutimos o período atual em Londrina e as transformações recentes na economia urbana londrinense associadas às consequências do advento do projeto neoliberal no Brasil nos anos 1990. O projeto neoliberal marcou a ruptura do padrão de integração social construído a partir da Segunda Guerra Mundial. Enfatizamos as consequências sobre o emprego e o empobrecimento relativo de grande parte dos trabalhadores, tema retomado na segunda parte do trabalho.

$\mathrm{Na}$ segunda parte do trabalho, nossas atenções se dirigem para análise do circuito inferior em Londrina a partir da caracterização de três atividades: o pequeno comércio estabelecido no Camelódromo de Londrina, o serviço de Mototáxi e o serviço de Entregas urbanas. No capítulo 4, discutimos os conflitos e as complementaridades entre a racionalidade hegemônica que se manifesta por meio do circuito superior e as contra-racionalidades (SANTOS, 2008) as quais se manifestam nas atividades do circuito inferior tomadas para investigação. Discutimos a formação das atividades, sua organização e funcionamento.

No capítulo 5, aproximamos mais a análise das questões da produção da pobreza no período atual e dos discursos sobre as formas de enfrentar as dificuldades que o período atual impõe à reprodução do modo de vida dos que vivem de seu trabalho. Procuramos caracterizar os trabalhadores e o trabalho nas atividades do circuito inferior em Londrina.

No capítulo 6, nossa atenção se volta para os fluxos e as escalas da ação nas atividades do circuito inferior. Buscamos desvendar as formas de cooperação e competição entre as atividades do próprio circuito inferior e entre o circuito inferior e o superior em Londrina. Identificar algumas relações entre Londrina e outras cidades que têm base nos fluxos e no funcionamento das atividades investigadas também foi um dos objetivos do capítulo. Em resumo procuramos analisar o circuito inferior em Londrina a partir de três atividades fortemente ligadas à expansão dos consumos e da circulação, processos que se ligam às modernizações características do período atual e que estão na base da reestruturação dos circuitos em Londrina, especialmente do circuito inferior. 


\section{PARTE I}

ECONOMIA URBANA E DIVISÃO DO TRABALHO 


\section{CAPÍTULO 1 \\ A formação de Londrina e o berço rural de sua economia urbana}

No Brasil a existência e o funcionamento dos circuitos da economia urbana são correlatos à constituição e a expansão do meio técnico - cientifico, processo complexo que preside a passagem do uso do território a partir dos diversos complexos agro-exportadores para o uso comandado por uma economia urbano-industrial. Essa transformação ampla na forma predominante do uso do território implicou, por exemplo, na transição da chamada urbanização pretérita para uma nova urbanização (SANTOS 1996).

Sobretudo no período pós-guerra, a nova urbanização acompanhou a crescente unificação e integração material do território e do mercado. Essa integração e a intensificação da divisão territorial do trabalho permitiram um formidável aumento dos intercâmbios e das articulações inter-regionais gerando uma verdadeira rede urbana nacional (CORREA, 2001, p. 101), cuja integração, interna e externa contribuiu e contribui pesadamente para a perpetuação e a produção de novas formas de desigualdade e escassez.

A nova urbanização, cuja expressão mais destacada é a formação dessa rede urbana nacional unificada, comandada pelas necessidades de reprodução do núcleo urbano-industrial paulista enseja o nascimento de novas especializações produtivas regionais e a redefinição do papel das já existentes, com forte impacto nos conjuntos urbanos mais antigos e também sobre o as redes urbanas regionais em formação.

Com a Revolução de 1930 a política de valorização do café favorável à cafeicultura paulista foi praticamente abolida. A ascensão do novo padrão de acumulação centrado na produção industrial e no trabalho assalariado urbano passou a exigir um novo papel para as exportações do café, que deveriam gerar divisas e sustentar a capacidade importadora necessária ao esforço de industrialização. Houve também a ampliação 
crescente do consumo de alimentos e de outros "bens de salário", alguns deles, a partir de então, produzidos industrialmente. Essas novas condições favoreceram o desenvolvimento da cafeicultura norteparanaense, que desde os anos 1920 estava se desenvolvendo no chamado Norte Pioneiro (BRAGUETO, 1996, p. 111, 112; PADIS, 1981, p.116 e 117).

A cafeicultura esteve diretamente ligada à origem dos circuitos da economia urbana em Londrina. Mas, as condições para o desenvolvimento da cafeicultura na região só estiveram plenamente ativas a partir de meados dos anos 1940, quando baixam os estoques de café no Brasil e o comércio mundial é paulatinamente retomado. Londrina, que nasce no contexto de um gigantesco empreendimento imobiliário, começa a ser construída no início dos anos 1930, em plena transição entre o meio técnico da circulação mecanizada e dos inícios da industrialização e o meio técnico científico (SANTOS e SILVEIRA, 2001) e antes que o cultivo do café pudesse voltar a oferecer rendas elevadas.

Os anos 1930, durante os quais Londrina e sua região começam a se estruturar, constituem um momento muito particular em que o Brasil está convulsionado pelas transformações políticas e pelos impactos da grande depressão, o que terá conseqüências para o arranjo espacial da região e, conseqüentemente, para os circuitos da economia urbana londrinense.

Torna-se necessário, portanto, fazer uma breve digressão sobre o contexto e as características da fase de montagem do arranjo espacial $^{7}$ de Londrina e de seu entorno regional. Dessa forma entendemos que é possível precisar as ligações entre o arranjo espacial e a forma e conteúdo dos circuitos em Londrina, no momento em que a cafeicultura se tornou a atividade hegemônica, momento que se estenderia até os anos 1960.

\footnotetext{
7 “A fase da montagem é a das primeiras localizações e do sistema de distribuição dessas localizações, que leva ao surgimento da extensão, reunindo num só ato três dos princípios lógicos - localização, distribuição e extensão - da ação geográfica, tudo orientado na prática da seletividade.” (MOREIRA, 2007, p. 82)
} 


\section{1 - A formação de Londrina e de seu entorno regional}

Construída a partir de 1929, a cidade de Londrina foi concebida no contexto de um gigantesco empreendimento imobiliário promovido por capitais ingleses ${ }^{8}$. Londrina tornou-se município autônomo em 1934 e após 75 anos, reúne uma população de 497.833 habitantes segundo as estimativas do IBGE para 2007. A cidade está situada na região Norte do Paraná, distante cerca de 380 km de Curitiba e 560 km de São Paulo.

Além do empreendimento imobiliário inglês que deu origem a Londrina, boa parte da região Norte do Paraná foi alvo de diversas experiências de colonização dirigida ${ }^{9}$. Contudo, o empreendimento imobiliário levado a cabo pelos capitais ingleses destacou-se frente às demais experiências de colonização dirigida. As razões para esse destaque são as dimensões das áreas adquiridas e as características do arranjo espacial efetivado pela Companhia de Terras. A localização e a posição de Londrina nada têm de aleatórias; resultam desse contexto histórico e tiveram forte influência sobre a formação da cidade e de sua economia urbana.

\footnotetext{
${ }^{8}$ A partir de meados dos anos 1920 a Companhia de Terras do Norte do Paraná (CTNP), subsidiária da Paraná Plantations, adquiriu do Governo do Paraná uma área total de 515 mil alqueires, contendo manchas de solo de alta fertilidade natural. Após a compra dessa vasta área de terras a oeste do Rio Tibgai, e antes mesmo de iniciar suas atividades na região, a Companhia de Terras tratou de adquirir também o trecho da "Estrada de Ferro São Paulo - Paraná", que interligava a localidade de Cambará - PR à ponta do ramal da Sorocabana em Ourinhos SP.

Ainda em 1929, em plena crise provocada pela quebra da bolsa de Nova Iorque, a Companhia de Terras deu inicio a construção de Londrina, que abrigaria sua sede no Brasil. Tratou de organizar os trabalhos de abertura de estradas, demarcação dos lotes rurais que seriam postos à venda e também dos primeiros núcleos urbanos. Iniciou também intensa propaganda voltada tanto a potenciais compradores estrangeiros quanto aos colonos de fazendas de café do interior paulista (CANCIAN, 1977).

9 Nadir Cancian (1977, p.132) explica que, no Paraná, a colonização dirigida foi praticada por diversas companhias nacionais e estrangeiras a partir do início do século XX. Esses gigantescos empreendimentos imobiliários geraram intensos negócios com a terra, os quais permitiram relativo enriquecimento ao Estado, lucros elevados aos grupos que investiram na especulação imobiliária e a possibilidade de antigos colonos de ascenderem à condição de proprietários, formando uma pequena burguesia. A prática da colonização dirigida dependia da demarcação prévia das terras pelo Estado, da construção de meios de comunicação e transporte, da venda de terras e de seu efetivo povoamento. Assim, no entorno das terras compradas pela companhia inglesa, havia outras iniciativas semelhantes, como as colônias de Primeiro de Maio e Sertanópolis, conduzidas por empresários nacionais e as colônias de Uraí e Assai, implantadas por empresas japonesas.
} 
Mapa 1

Norte do Paraná: Áreas de colonização dirigida e não dirigida

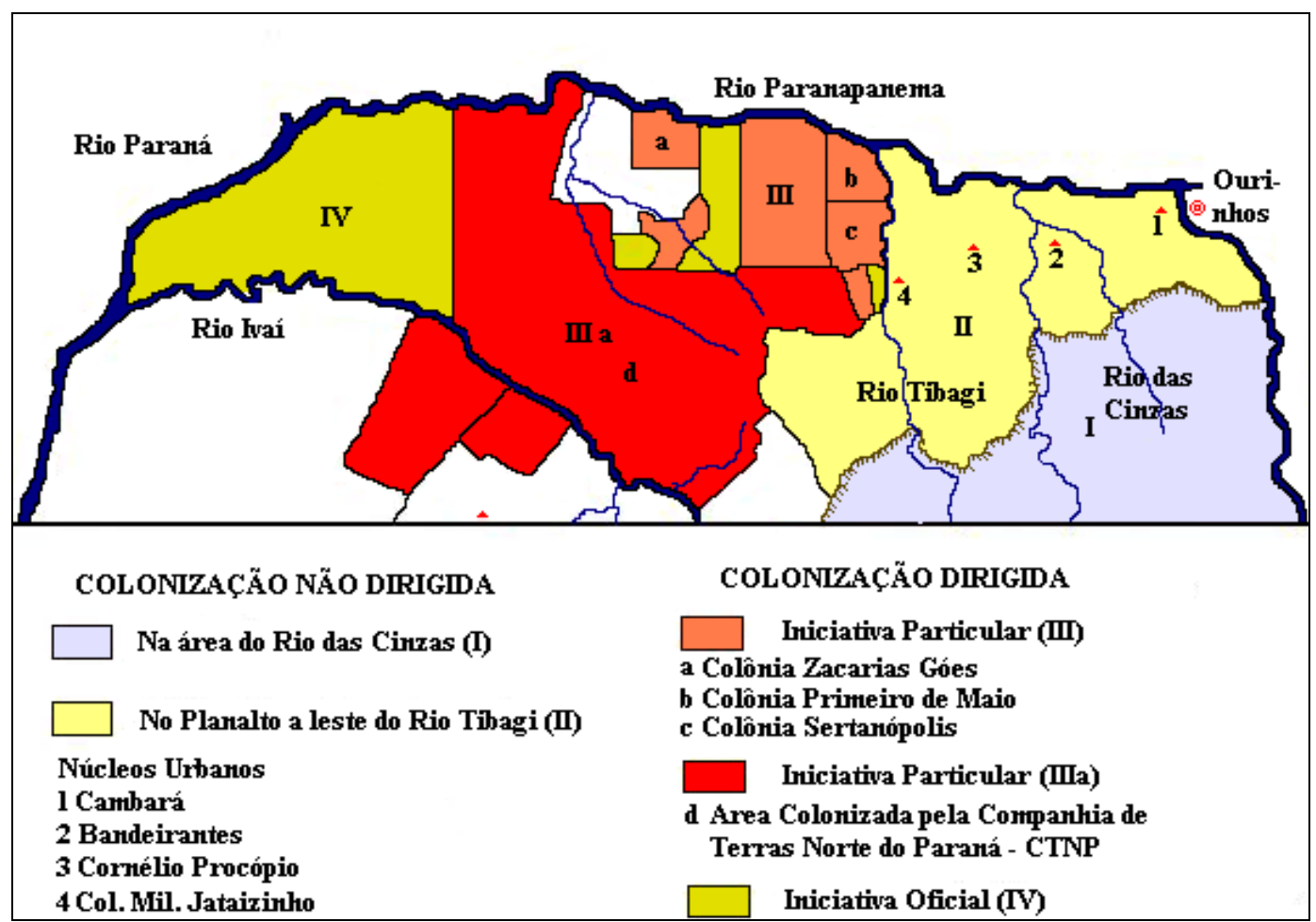

Fonte: Adaptado do mapa Colonização do Norte do Paraná, Nice Lecocq Müller (2007, p.33)

A forma e o conteúdo do arranjo espacial da região colonizada pela Companhia de Terras do Norte do Paraná $\left(\right.$ CTNP) ${ }^{10}$ tiveram significativa importância para o desenvolvimento posterior do Norte do Paraná e da cidade de Londrina.

A influência do arranjo espacial sobre a dinâmica do desenvolvimento regional se deve a uma combinação de fatores. $O$ primeiro deles foi a dimensão dos lotes rurais comercializados pela Companhia de Terras que resultou na expressiva presença de pequenas propriedades em uma área de solo fértil e clima úmido. O segundo foi a localização e distribuição de pequenos núcleos urbanos (os patrimônios) nas proximidades das pequenas propriedades rurais.

\footnotetext{
${ }^{10}$ As origens de Londrina no contexto da colonização dirigida das terras do Norte do Paraná foram analisadas por diversos artigos de geógrafos publicados entre os anos 1930 e 1950, como por exemplo: A zona pioneira do Norte-Paraná de Pierre Monbeig de 1935; O problema das frentes pioneiras no estado do Paraná de Lysia Bernardes em 1953; Aspectos da geografia urbana de Londrina de Neyde Prandini em 1954; Contribuição ao estudo do Norte do Paraná de Nice Lecocq Müller em 1956. Esses e outros artigos importantes sobre o Norte do Paraná foram recentemente resgatados na coletânea organizada por Márcia Siqueira de Carvalho e Tânia Maria Fresca, lançada em 2007 e intitulada “Geografia e Norte do Paraná: um resgate histórico”.
} 
Já o terceiro é a rede viária, que incluía estradas vicinais que estabeleciam a conexão entre as propriedades rurais e os patrimônios, a ferrovia e as rodovias principais ao longo das quais foram localizados os núcleos urbanos. Esse conjunto, além dos patrimônios, era composto também por cidades maiores como Londrina e, posteriormente, Maringá, Cianorte e Umuarama onde se concentraram as frações superiores dos circuitos de comercialização da produção rural e de abastecimento de toda população da região.

A rede viária, especialmente a ferrovia, juntamente com outros meios de comunicação, possibilitou uma forte articulação da região em formação aos centros dinâmicos da economia nacional e aos portos de Santos e Paranaguá.

\section{Mapa 2}

Paraná: situação das terras adquiridas pela CTNP e sistema viário - 1955

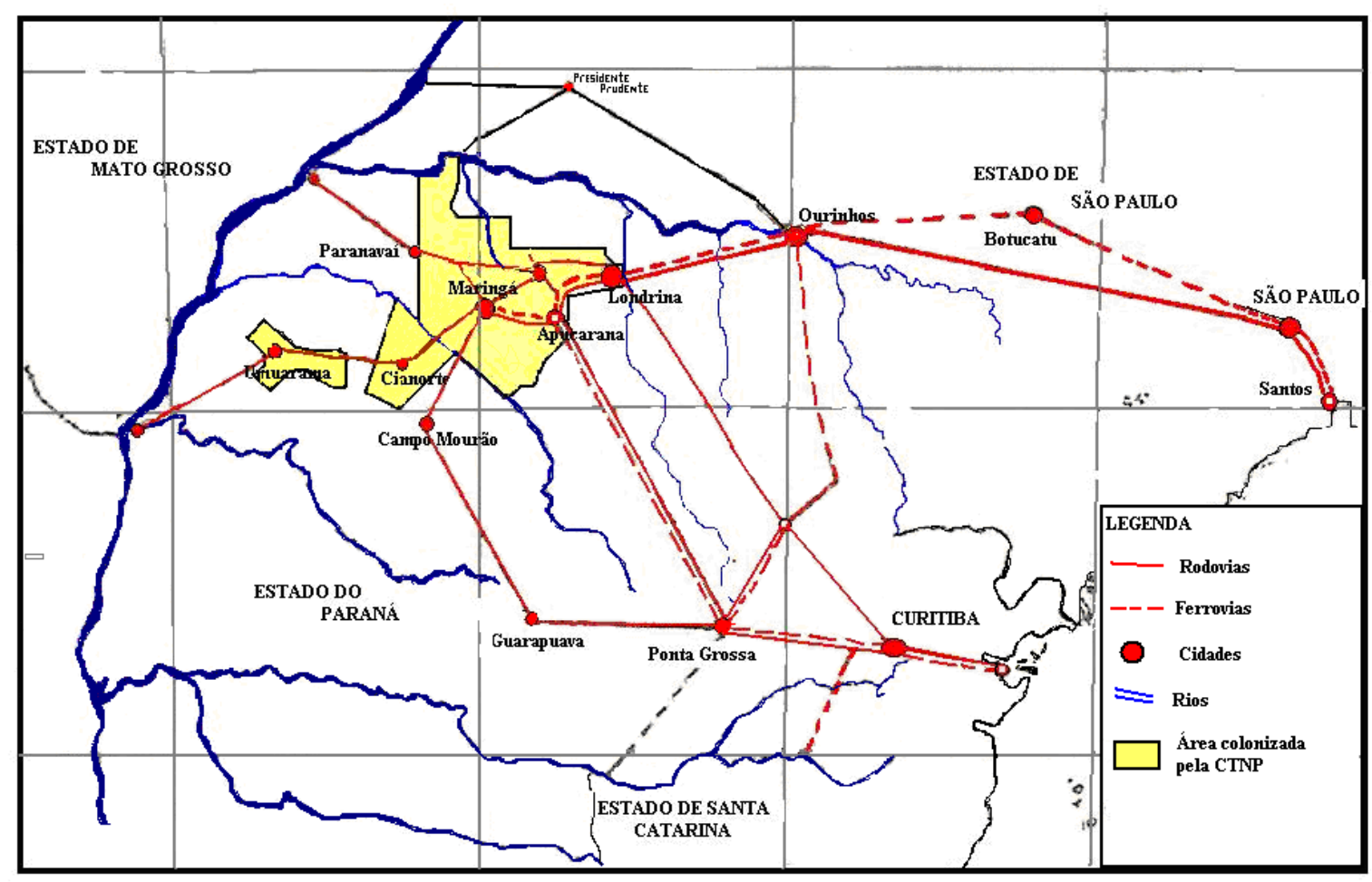

Fonte: Yamaki (2003, p.72)

A distribuição dos núcleos urbanos, a sua interligação por meios modernos de transporte e comunicação, a hierarquia de suas funções e as características do meio construído tiveram importância fundamental na formação da rede urbana regional (FRESCA, 2004). 
Essa combinação de fatores foi decisiva para a inserção do Norte do Paraná na divisão territorial do trabalho nas escalas nacional e internacional. Londrina, por ser um ponto privilegiado da articulação das três escalas, isto é, a escala local ou regional, nacional e internacional, que caracterizaram a inserção do Norte do Paraná na divisão territorial do trabalho, tornou-se o mais importante e dinâmico centro urbano de toda região (NAKAGAWARA, 1972). 


\subsection{1 - A importância do conhecimento prévio na escolha das áreas adquiridas pela Companhia de Terras}

O processo de montagem do arranjo espacial (MOREIRA, 2007) nas áreas adquiridas pela Companhia de Terras foi orientado por diversas informações sobre o potencial econômico da região. Entretanto, todo esse processo nada tem de idílico ${ }^{11}$. É preciso evitar a (con)fusão ideológica que, via de regra se faz, ao tomar o empreendimento imobiliário da Companhia de Terras como matriz do progresso e da transformação de toda região (TOMAZI, 1997). Esse tipo de fusão ideológica acaba por reduzir a complexidade e a diversidade das práticas espaciais subjacentes à configuração desse recorte territorial, tanto no plano objetivo como no plano subjetivo

A esse respeito destaca-se a argumentação de Tomazi (1997) que enfatiza a necessidade de desmitificar o que ele denomina "O discurso Norte do Paraná" e de caracterizar o processo que se intensifica nos anos 1920 como processo de (re)ocupação. A (re)ocupação implica destacar que no "Sertão do Tibagi", antes da implantação de colônias, havia presença de diversos grupos de ocupantes como: caboclos que praticavam agricultura itinerante, safristas, posseiros e grupos indígenas. Havia também terras griladas. O importante é ressaltarmos que o novo uso do território inerente à inserção da região na divisão territorial do trabalho no período técnico científico gerou inúmeros conflitos com esses grupos que foram espoliados e deslocados pelo avanço das frentes pioneiras.

Tratar esse momento da montagem do arranjo espacial como (re)ocupação é, portanto, encontrar o lugar específico das ações da Companhia de Terras no contexto complexo da produção social do espaço norte-paranaense e de sua integração ao meio técnico-cientifico que se

\footnotetext{
11 Há toda uma produção de teses historiográficas e sociológicas que fazem a crítica dos discursos apologéticos sobre a região Norte do Paraná e sobre Londrina. Essa produção, a título de exemplo, pode ser representada pelos trabalhos de José Joffily (1985), Sonia Adum (1991), Miguel Arias Neto (1993) e Nelson D.Tomazi (1997). Esses trabalhos descortinam a importância da dimensão simbólica ligada especialmente à ocultação das tensões, conflitos e a luta pela hegemonia na região.
} 
expandiu velozmente no Sul e Sudeste do Brasil a partir de meados da década de 1940 .

A respeito dos objetos e ações diretamente relacionados à Companhia de Terras salientamos os seguintes aspectos: o conhecimento prévio e estratégico do meio natural e das dinâmicas territorial e econômica brasileiras ${ }^{12}$, as práticas espaciais ensejadas e a necessidade estratégica de adequá-las às conjunturas, nacional e mundial, conferindo aos dirigentes da Companhia de Terras aquele "saber estratégico", em geral apanágio de minorias dirigentes de que fala Yves Lacoste (1988, p.41).

A aquisição dos direitos sobre a ferrovia que estabeleceria a ligação de Londrina e seu entorno regional com Santos e a Cidade de São Paulo exemplifica com clareza a importância do conhecimento prévio que orientou as escolhas dos dirigentes da Companhia de Terras, especialmente do Sr. Simon Fraser, também denominado Lord Lovat.

Em 1924, antes de adquirir as terras em que implantaria o empreendimento, Simon Fraser esteve no Norte do Paraná a convite de fazendeiros de origem paulista radicados na região e interessados na melhoria da posição de suas terras, por meio do acesso ao transporte ferroviário. Esses fazendeiros haviam iniciado uma ligação ferroviária Cambará-PR e Ourinhos-SP, ponto terminal da estada de ferro Sorocabana desde 1908. Havia, portanto, pleno conhecimento das reais possibilidades técnicas de produzir a localização das terras do norte do Paraná, a partir

\footnotetext{
12 Quanto ao conhecimento prévio e estratégico da dinâmica econômica e territorial nacional, Tomazi (1997, p.185,186) faz menção a uma viagem realizada por Thomas P. Bigg-Whitter relatada em um livro publicado em 1875 em Londres: "Pioneeiring in South Brazil", que em 1876 levaria seu autor a realizar uma conferencia na Real Sociedade Geográfica de Londres, falando sobre o vale do Rio Tibagi. Esse inglês teria sido o primeiro a propor uma ferrovia partindo da região de Ourinhos-SP, atravessaria o Paraná e chegaria ao Paraguai. O investimento em ferrovias que atravessassem zonas produtoras de matéria prima e gêneros agrícolas era, de fato, muito coerente com as projeções inglesas para a América do Sul, na condição de receptora de capitais ingleses e fornecedora de uma variada gama de produtos tropicais aos mercados europeus, gerando fluxos nos quais financiamentos, seguros e fretes eram controlados pelo capital financeiro inglês. Informações minuciosas sobre a topografia, potencialidade agrícola, quantidade de madeira e recursos hídricos estavam ao alcance de Simon Fraser, fundador da CTNP e seus sócios, por meio da documentação da "Paraná and Mato Grosso Survey Expedition".
} 
da construção de uma ferrovia que a interligaria às já existentes na região da Alta Sorocabana no Estado de São Paulo ${ }^{13}$.

Segundo Tomazi (1997) é bastante plausível supor que, de início, a ferrovia fosse o investimento mais atrativo para os ingleses. Nesse caso, o interesse dos ingleses pelo empreendimento imobiliário, de que resultou a construção de Londrina, de mais de 60 cidades no Norte do Paraná e de milhares de propriedades rurais, seria relativamente secundário.

O importante nessa questão é frisar que o uso do território no contexto do empreendimento inglês se pautou por um amplo conhecimento prévio das possibilidades oferecidas pela região. Isso trouxe conseqüências específicas para a produção do arranjo espacial como, por exemplo, associar a viabilidade da ferrovia com o abastecimento dos habitantes da região e com o escoamento da produção rural, inclusive a intensa extração de madeira decorrente da progressiva ocupação da área em que viria a atuar.

Por último, mas não menos importante, há a estreita ligação entre o governo provincial do Paraná e os latifundiários já instalados na região e interessados na elevação da renda da terra que a moderna acessibilidade proporcionada pela ferrovia Ihes traria (PAYES, 1984). Segundo Florestan Fernandes (1987), o aparelhamento do país no contexto da montagem de uma economia nacional capitalista e dependente sob o controle de elites políticas diretamente relacionadas ao complexo agrário exportador, reforçou o imperialismo e a inserção subordinada na divisão internacional do trabalho. À medida que se efetivava a integração brasileira ao mercado internacional, também

\footnotetext{
${ }^{13}$ Em seu livro José Joffily (1985) argumenta que durante os anos 1920, no período do Governo Arthur Bernardes, o Estado brasileiro solicitou empréstimos volumosos à casa bancária Rotschild. Para avalizar um desses empréstimos, que acabou não se efetivando, os Rotschild solicitaram um extenso e detalhado relatório sobre as condições econômicas do país e suas potencialidades. Os encarregados de produzir esse relatório deveriam ter amplo acesso a todos os documentos e informações que solicitassem. A equipe foi batizada com o nome de Missão Montagu. O Sr. Simon Fraser, o Lord Lovat, que mais tarde articularia a criação da Paraná Plantations e da CTNP fazia parte dessa equipe como técnico em agricultura e reflorestamento.
} 
cresciam internamente as pressões para a eliminação de fatores que encareciam a produção agrícola ${ }^{14}$.

No Paraná, a construção do aparelho burocrático do Estado local e da capacidade de ação sobre sua parcela do território exigia recursos financeiros muito além daqueles gerados pela pecuária, pelo tropeirismo e pela atividade ervateria, concentradas no sul do Paraná e nos Campos Gerais. Decorre daí a política de concessão de terras para a colonização empreendida por empresas particulares que gerava renda para o estado sem qualquer ônus (CANCIAN, 1977, p.116) e a possibilidade real da Companhia de Terras adquirir um grande volume de terras a baixo custo e em condições de pagamento muito favoráveis ${ }^{15}$.

Tomazi (1997, p. 190) revela que pouco antes de a Companhia finalizar a aquisição das terras no "sertão do Tibagi", ou seja, em maio de 1926, o governo provincial paranaense recebera um empréstimo e bancos ingleses no valor de sete milhões e duzentos mil dólares para fazer frente a divida acumulada do Estado e para investir no porto de Paranaguá, também alvo do interesse inglês.

Outro episódio emblemático da relação estreita entre o Estado e a Companhia de Terras se deu quando da proibição de plantio de novos cafeeiros em todo território nacional por meio do decreto federal n. ${ }^{0} 19.688$ de fevereiro de 1931. Logo após esse evento os diretores da Companhia de Terras reuniram-se em Cambará com o interventor Mario Tourinho e aí discutiram a possibilidade de que esse decreto não atingisse o Paraná, intento que rapidamente lograram conseguir (TOMAZI, 1997,

\footnotetext{
${ }^{14}$ No caso de São Paulo vale lembrar a política de imigração subvencionada pelo governo provincial associada à expansão das ferrovias no contexto do que Santos e Silveira (2001) denominaram "mecanização do território" que contribuíram para aceleração da "produção de fazendas de café" no oeste paulista, como negócio altamente lucrativo e que induziu a superprodução e as crises na comercialização do produto (MARTINS, 1979). No Paraná a fragilidade financeira do governo provincial e o peso das elites radicadas nas produções do sul do estado faziam recair sobre os fazendeiros paulistas instalados no chamado Norte Pioneiro as pressões da incorporação dessa área ao mercado internacional. O principal obstáculo era a ausência de transporte moderno capaz de realizar a renda diferencial propiciada pela maior fertilidade natural dos solos do Norte do Paraná.

${ }^{15}$ Há em diversos trabalhos sobre a região e sobre a Londrina a descrição da seqüencia das compras e o mapa das terras adquiridas pela CTNP: Bragueto (1996); Padis (1984) apenas como exemplos e em mais uma infinidade de artigos, álbuns comemorativos, sites sobre Londrina, etc. Os famosos 515.017 alqueires ou 1.246.341 ha adquiridos entre 1925 e 1927 devem ser acrescidos de mais 250.000 alqueires ou 605.000 ha recebidos como subsídio oficial por conta da construção da ferrovia, sobre cujo destino pouco se sabe.
} 
p.210). Dessa forma a companhia criava condições para que a cafeicultura se tornasse uma possibilidade concreta de viabilização de seu empreendimento, sobretudo da ferrovia. 


\section{1 .2 - Estratégias, seletividade e adequação às conjunturas na produção do arranjo espacial de Londrina e seu entorno regional}

Uma vez definida a localização das áreas sob o controle da Companhia de Terras por meio da aquisição e demarcação das mesmas e pela efetivação do projeto de expansão da ferrovia, cabe ressaltarmos o aspecto da distribuição das cidades e propriedades rurais na área colonizada.

A Companhia de Terras promoveu uma repartição das terras sob seu domínio em milhares de pequenas propriedades rurais cujo tamanho aumentava a partir das vizinhanças com os núcleos urbanos. Além disso, determinou a criação de núcleos urbanos com diferentes tamanhos ao longo das principais vias de penetração nas suas terras.

Essas vias eram a ferrovia e uma rodovia principal que the era paralela. A construção dessas vias levou em consideração as dificuldades impostas à circulação pela alta pluviosidade típica do clima subtropical da região. Por isso, foram construídas na parte mais elevada do relevo, no caso, o espigão que divide as bacias dos rios Ivaí e Paranapanema.

Se por um lado esses aspectos apontam para a existência de um planejamento anterior para o processo de (re)ocupação das áreas sob domínio da Companhia de Terras, a definição do tamanho dos lotes rurais que seriam comercializados deveu-se muito mais à conjuntura adversa dos anos 1930.

O empreendimento visava à produção dos lotes urbanos e rurais como mercadorias. O caráter "planejado" da definição dos tamanhos e da distribuição das parcelas de terra de uso rural é objeto de discussão ${ }^{16}$. Pierre Monbeig ao comentar a preponderância da pequena

\footnotetext{
${ }^{16}$ Nelson D. Tomazi (1997) chega a conjecturar que os trabalhos de Pierre Mombeig sobre as frentes pioneiras no Paraná, teriam sido a origem da idéia de que o planejamento seria a marca distintiva do empreendimento da CTNP e que somente a posteriori isso teria se tornado argumento recorrente no contexto do que Tomazi denomina "O discurso Norte do Paraná". No entanto, desde o inicio da objetivação do empreendimento, que foi primeiro definido em um mapa detalhado, a escolha do eixo de penetração principal ao longo do qual foram situados núcleos urbanos, estava definida. O que se discute portanto, é a funcionalidade que esse arranjo adquiriu
} 
propriedade e, com ela, da policultura, aponta que isso não se devia a fatores como as condições de solo ou influências étnicas, relativas à grande presença de imigrantes no início dos anos 1930, posto que nenhum desses fatores impediria a formação de grandes propriedades. $O$ autor enfatizava que, no caso de Londrina, se tratava de uma organização nova, um grande empreendimento capitalista, e assim indagava:

É ainda necessário não esquecer que se trata de uma organização nova da colonização como um financiamento de typo novo: o grande emprehedimento de typo capitalista; e sendo assim, não acha elle levado por sua estructura, pelas suas múltiplas ligações, pela somma de seus interesses a favorecer o retalhamento do solo entre um grande número de possuidores? (sic) (MONBEIG, 2007, p.9).

Em outra obra o mesmo autor é ainda mais enfático acerca de como as companhias de colonização tiveram de se adaptar à conjuntura recessiva dos anos 1930, em função daqueles que poderiam se interessar por sua mercadoria:

[...] Faz-se o loteamento quando um comerciante procura tirar proveito, vendendo o melhor possível a mercadoria que possui e que, no presente caso, é a terra. Como sempre, o negociante procura simplificar seu trabalho e oferecer aos seus clientes eventuais algo que possa atraí-los, satisfazê-los. As grandes companhias que fazem o loteamento das glebas são levadas então, antes de tudo, a considerar as necessidades e possibilidades da clientela; é na mediada que tomam conhecimento destas possibilidades e satisfazem estas necessidades que elas realizam um verdadeiro trabalho de colonização. A clientela é composta de chefes de família de recursos modestos. O antigo assalariado de uma fazenda, o colono, só pode fazer umas parcas economias; o imigrante que acabou de desembarcar, não conta com um pecúlio muito grande[...] Em conseqüência, as terras que esses pioneiros podem comprar e cultivar, devem ter dimensões limitadas (MONBEIG, 1957, p.116).

As dificuldades econômicas trazidas pela grande depressão parecem ter levado a Companhia de Terras a considerar mais detalhadamente quem poderia se constituir como demanda solvável para essa mercadoria, bem como as condições de sua rápida realização. Conforme Tomazi (1997, p.219), até meados dos anos 1940, mais de

\footnotetext{
a partir da Segunda Guerra e que decorre das táticas de realização da renda fundiária inerente à valorização dos
} lotes urbanos e rurais e que, em parte, escaparam as possibilidades de controle da CTNP. 
$90 \%$ das 10.061 propriedades vendidas foram pagas a vista, indicando que os compradores possuíam algum recurso financeiro. A venda de pequenas propriedades também estaria associada à viabilização da ferrovia ${ }^{17}$.

Outro argumento, ligado ao tipo de trabalho requerido para a montagem do arranjo espacial da região é apresentado por Payes (1984, p.74)

Antes da crise de 1929, o capital inglês compreendeu que o triunfo do seu negócio imobiliário (que começou em 1930) devia realizarse com base em pequenos lotes agrícolas, a serem vendidos a pequenos a futuros produtores de mercadorias, $[\ldots]$

Todavia isso, não significa que candidatos capitalistas por áreas relativamente grandes, não pudessem adquirir terras da CTNP. A intenção explícita era favorecer e apoiar o pequeno proprietário, sem, porém, afastar o de maiores recursos. Significava sim, que os pretendentes a produtores simples de mercadorias se submeteriam, com menores pressões e no ritmo esperado e necessário ao investimento total; ás condições de acesso e exploração da terra. Lembremos que nos referimos a uma zona de fronteira agrícola, que requeria um grande dispêndio de trabalho, onde os futuros compradores realizariam manualmente tarefas altamente rudes e desgastantes, como o desbravamento, por exemplo, sustentados apenas em pequenos recursos monetários e na própria força de trabalho familiar.

A Companhia de Terras realizava esforços consideráveis para atrair imigrantes de toda Europa ao seu empreendimento. Nadir Cancian (1977, p.147) que estudou os fichários da Companhia nos quais havia indicações detalhadas sobre cada comprador, constatou que, entre 1930 e 1938, preponderavam os compradores estrangeiros, sobre os nacionais, e, no geral, a quase totalidade dos compradores eram lavradores.

A seletividade (MOREIRA, 2007), ou em outros termos, a intencionalidade possível na definição dos objetos geográficos que comporiam o arranjo espacial, recaiu, portanto, sobre as pequenas

\footnotetext{
${ }^{17}$ Arias Neto (1993, p. 24) indica que um engenheiro alemão de sobrenome Nixdorf, chegou a Londrina por volta de 1932, convidado pelo ministro alemão para estudar a criação de uma colônia alemã nas terras da CTNP. Esse engenheiro teria aconselhado um vice-presidente da Paraná Plantations em visita ao empreendimento, a considerar a venda das terras a pequenos lavradores de modo a criar para a ferrovia uma maior quantidade de fretes e de passageiros a partir de povoados e cidades vizinhas.
} 
propriedades $^{18}$ e sobre potenciais compradores que ansiavam ter seu próprio pedaço de terra, a ponto de enfrentar as duras condições dessa empreitada.

A partir de 1939, com o início da guerra, o fluxo de imigrantes se reduz drasticamente e entre os compradores de lotes da Companhia agora figuravam colonos do Norte Pioneiro e do interior paulista. A conjuntura que desde 1937 havia reduzido as exportações brasileiras de café de 18 milhões de libras esterlinas para pouco menos de 15 milhões em 1939 (CANCIAN, 1977, p.162), gerou uma crise profunda que ameaçava o setor cafeeiro, afastando os bancos e até mesmo especuladores e intermediários do comércio do café. Tal situação afetou duramente as grandes propriedades, inclusive as já instaladas no Paraná, nas quais os investimentos na formação de cafezais e em todo equipamento, edificações e pessoal necessários à etapa beneficiamento, exigiam retornos monetários maiores ${ }^{19}$.

Outro aspecto apontado por Antonio Mungüia Payes (1984) é que, com a entrada em operação dos novos trechos da Ferrovia ParanáSão Paulo construídos pela Companhia inglesa a partir de 1928 e a liberação de colonos das fazendas paulistas e do Norte Pioneiro, teve início o que ele denomina de "rush" populacional em direção às terras do Norte Novo.

Em 1930 havia apenas uma ou duas dezenas de pessoas ligadas à Companhia de Terras na área do patrimônio Três Bocas, gleba onde seria iniciada a construção de Londrina, além de posseiros e caboclos radicados há muito nas áreas ao sul adjacentes às terras da Companhia. Apenas dez anos depois, por ocasião do Censo de 1940, havia por volta de

\footnotetext{
${ }^{18}$ Nadir Cancian (1977, p.158) transcreve um depoimento de Mister Thomas, ex-diretor da CTNP residente em Londrina, que, sobre o período de meados dos anos 1930, afirmou: O tipo de gente de quem se podia esperar a compra de terras não possuía dinheiro - ou se dispunha de um pouco, não encontrava razão para confiar nas circunstâncias dos tempos". A isso some-se a intensa propaganda promovida pela companhia no exterior indicando que se pretendia promover a re-ocupação da região com imigrantes, estratégia que foi inviabilizada pela Segunda Guerra.

${ }^{19}$ Cancian (op.cit, p.272) oferece uma rica e interessante comparação quanto aos investimentos em edificações, equipamentos e pessoal nas microrregiões do Norte Pioneiro e do Norte Novo de Londrina. No chamado Norte Pioneiro o cultivo do café se concentrava em grandes propriedades, nas quais os investimentos em maquinário e pessoal indicam que as etapas de beneficiamento e classificação do produto eram internas as fazendas.
} 
75 mil pessoas no então município de Londrina, dentre os quais 10.531 pessoas na sede do município: a cidade de Londrina.

A ferrovia, elemento fundamental desse deslocamento, relativo à prática da tecnificação (MOREIRA, 2007, p.84) ensejada pela Companhia de Terras, foi, segundo Payes (1984, p.66), não apenas o meio mais utilizado para chegar à região, mas, em certas épocas, a das chuvas, o único possível, pois as estradas ficavam intransitáveis. Logo, ao redefinir a localização e a acessibilidade de suas terras, a Companhia de Terras viabilizava sua efetiva ocupação.

O crescimento da população do Norte do Paraná como um todo chamou a atenção dos geógrafos da época. Entre os censos de 1920 e 1940 o Estado absorveu meio milhão de novos habitantes (550.565 hab.) sobre uma população 685.711 hab., um crescimento de $80,2 \%$, a taxa de crescimento mais elevada do país inteiro à época (BERNARDES, 2007, p.63).

As regiões do Paraná em que se verificou o maior crescimento foram justamente o norte e o oeste do Estado, em que o crescimento regional foi de $100 \%$.

Para evitar a dispersão e o isolamento do habitat rural que produzia a Companhia de Terras projetou e iniciou a construção de uma densa rede de estradas vicinais. A importância dessa rede de estradas estava justamente em seu poder de aumentar a densidade da população regional. A esse respeito Marx (1998, p.407) assegurava que:

Constitui condição material para a divisão de trabalho na manufatura o emprego ao mesmo tempo de certo número de trabalhadores. De maneira análoga, a divisão do trabalho na sociedade depende da magnitude e da densidade da população, que corresponde à aglomeração de operários numa oficina. Mas essa densidade é algo relativo. Um país relativamente pouco povoado, com meios de transporte desenvolvidos, possui uma população mais densa do que um país mais povoado com escassos meios de transporte $[\ldots]^{\prime \prime}$ 
Mapa 3

Rede de estradas do entorno regional de Londrina, 1938

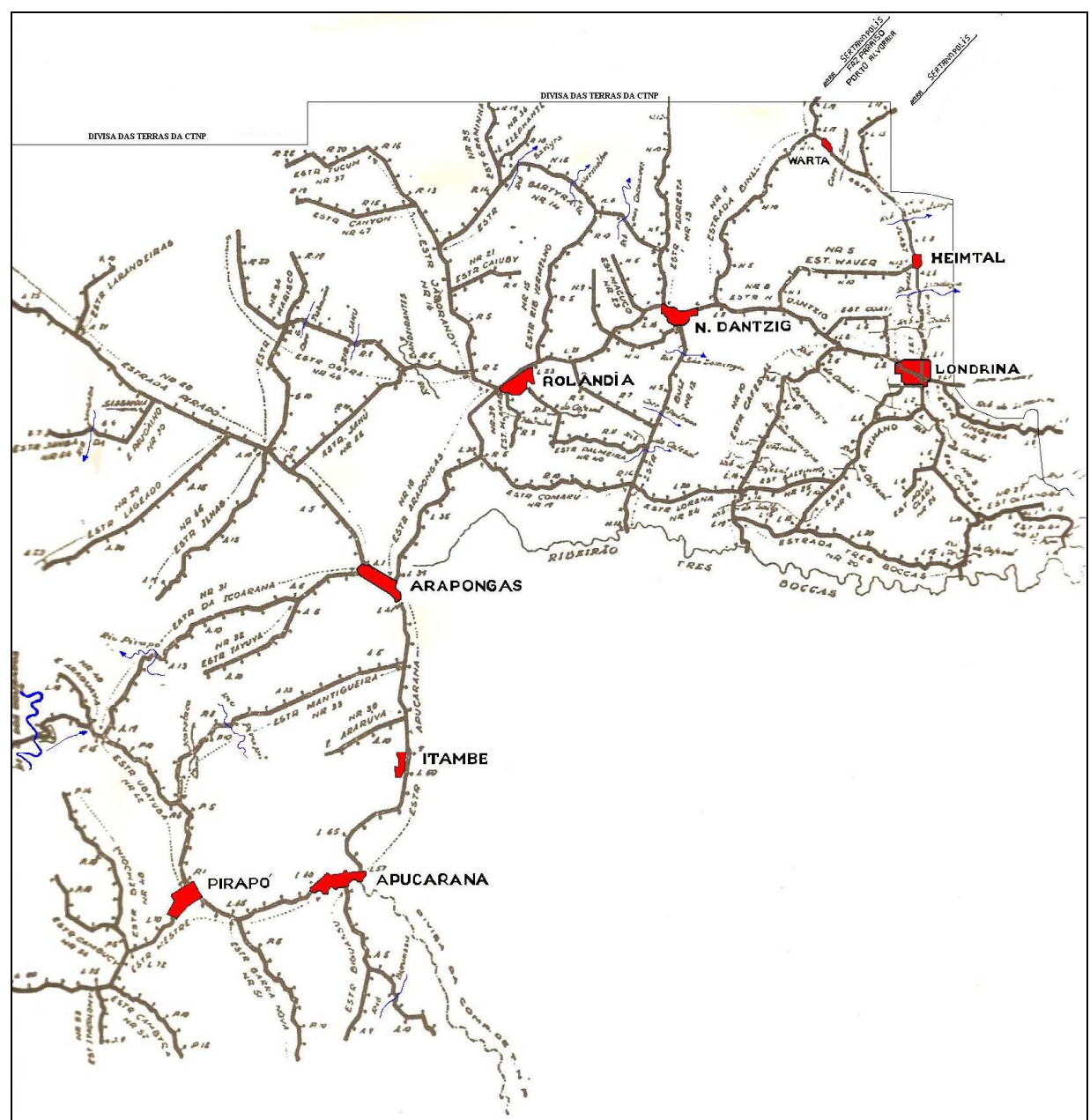

Fonte: Yamaki (2003, p.62,63).

Figura 1

Estrada Vicinal no Distrito da Warta - 1957

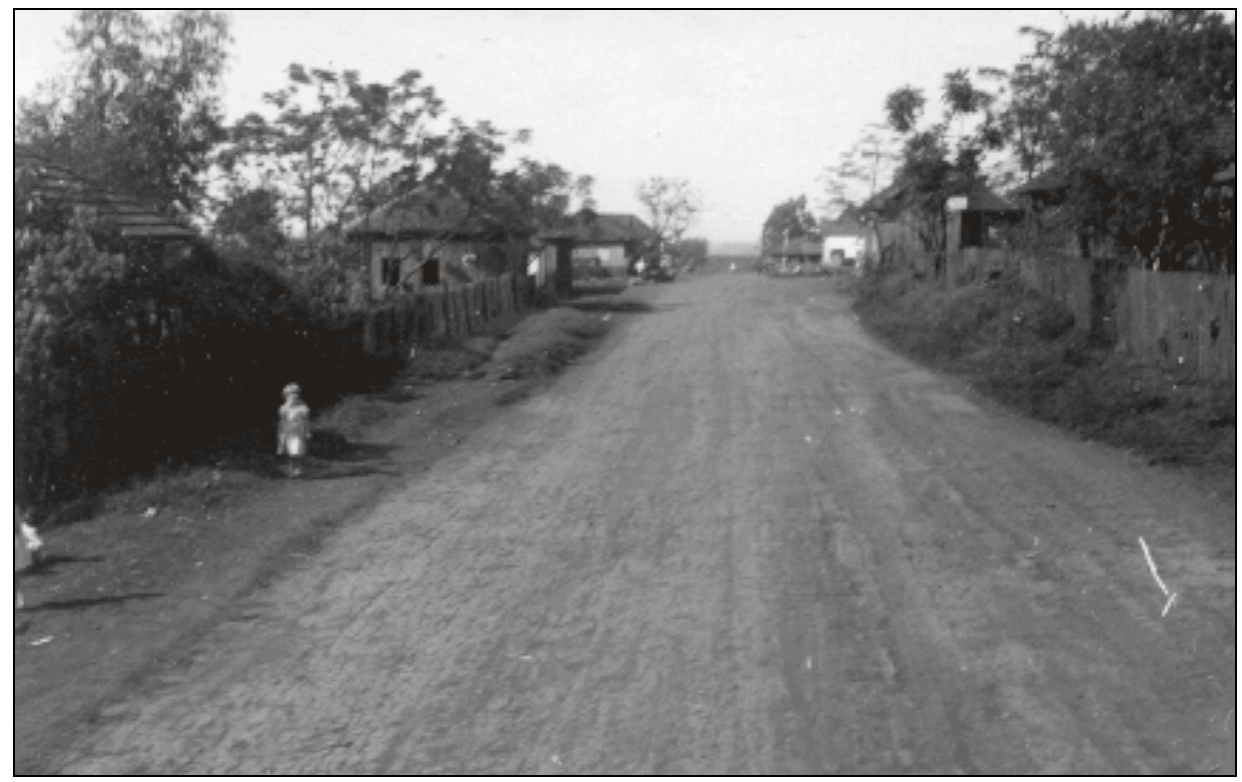

Fonte: Arquivo do Museu Histórico de Londrina Autor: Oswaldo Leite 
De acordo com Nice Lecoq. Müller (2007, p.69) entre 1929 e 1935 estavam abertas $3.615 \mathrm{Km}$ de estradas. Durante a chamada fase inglesa da Companhia, entre 1925 e 1944, foram abertos seis núcleos urbanos: Londrina (1929/30), Cambé (1930), Arapongas (1935), Rolândia (1935), Mandaguari (1937) e Apucarana (1938). Esses núcleos foram conectados inicialmente pela estrada principal.

A rodovia precedeu a ferrovia como técnica incorporada ao território e com ela multiplicaram-se carroças e caminhões. Em 1937 havia, só em Londrina, 148 caminhões e camionetas e 474 carroças (ASSOCIAÇÃO COMERCIAL e INDUSTRIAL de LONDRINA, 2007, p.6). A ferrovia Chegou a Londrina e a Cambé em 1935, a Rolândia em 1939, a Apucarana em 1943, a Maringá em 1954 e a Cianorte em 1973 (BRAGUETO, 2007, p.35)

A densidade do arranjo espacial crescia à medida que se estendia a infraestrutura e, com ela, a valorização. Em 1930/31, quando iniciou suas vendas e a intensa propaganda, o preço do alqueire era de 400 mil réis. Em pouco mais de dez anos havia dobrado, atingindo o valor de 800 mil réis 1941/43, ao longo de uma conjuntura fortemente recessiva. Durante esse período a Companhia vendeu mais 100 mil alqueires, pouco mais de $20 \%$ da área sob seu controle.

Com a constituição da municipalidade em Londrina em 1934, a conservação das estradas abertas no município, que antes cabia à Companhia de Terras, passou a ser incumbência da nova Prefeitura. $O$ novo município teve então que, ao longo do tempo, equipar-se para as novas tarefas, criando inclusive normatização específica para esse fim, como as contribuições de melhoria ${ }^{20}$. O ônus da manutenção do arranjo espacial, no entanto, não foi pago apenas por meio de impostos; houve também a participação direta em turmas de trabalho para a conservação das estradas.

\footnotetext{
${ }^{20}$ A Lei n. ${ }^{\circ} 15$ de 24 de julho de 1936 definia em seu artigo segundo a criação da referida taxa, que era de 3 mil réis por alqueire destinados a construção, reconstrução e conservação de estradas de rodagens e vicinais (LINARDI, 1995. p. 124).
} 
A conservação das estradas rurais tornava-se um problema realmente sério para toda área a ser colonizada, em virtude da destruição das estradas ou "picadas", nas estações chuvosas. Enquanto o poder local não organiza sua "patrulha mecanizada" a prática da conservação das estradas rurais e construção eventual de pontes era resolvida através de mutirão, envolvendo a Cia de Terras, o poder local e os proprietários rurais (RAZENTE, 1984, p.219)

Uma vez constituído o arranjo espacial definido pela Companhia de Terras passou a exigir mais e mais trabalho para que a artificialidade das formas necessárias às funções esperadas pudesse manter-se e suportar os novos usos: o da terra roxa como objeto de trabalho e dos lotes urbanos e rurais como mercadorias. Quando o ônus dessa manutenção começou a se tornar pesado, a Companhia de Terras transferiu os encargos exigidos pelas novas formas espaciais ao poder público sem, contudo, perder o controle, isto é, o poder de decidir ${ }^{21}$. Assim a companhia tinha sob seu controle toda a área do município que se estendia até as barrancas do Rio Paraná a oeste, e do Rio Paranapanema a norte e a noroeste. Os primeiros desmembramentos nessa área só ocorreram a partir de 1943, quando a Companhia de Terras estava transferindo suas propriedades a grupos financeiros nacionais ${ }^{22}$.

O controle monopólico pode ser avaliado pelo conjunto de empresas e serviços administrados por membros da Companhia de Terras ou que estavam sob se domínio direto.

Além disto, estão sob seu controle direto ou indireto através das
propriedades da CTNP, da Companhia Ferroviária São Paulo -
Paraná (como vimos, empresa do mesmo grupo), da Prefeitura
Municipal (dirigida por Davids dos escritórios da CTNP) e mesmo
de empresas particulares pertencentes a membros de seu "staff
diretor", o serviço de transportes (ferrovias, carroças, charretes,
jardineiras), o abastecimento de água e luz, as comunicações
telefônicas e telegráficas (implantados em vários povoados do
município nos escritórios da própria CTNP ou nas casas comerciais

\footnotetext{
${ }^{21}$ Segundo Miguel Arias Neto (1993) entre 1935 e 1940 a CTNP assegurou o controle monopólico sobre sua área de concessão porque conseguiu que o Sr. Willie Davids que era diretor da CTNP se tornasse, simultaneamente, Prefeito de Londrina, evitando assim possíveis conflitos de interesse com a nova municipalidade

${ }_{22}$ Os representantes desses grupos eram conhecidos capitalistas paulistas como: Gastão Vidigal, Gastão Mesquita Filho, Arthur Bernardes Filho e Irmão Soares Sampaio. Uma série de transações posteriores absorveu as parcelas acionárias pertencentes a Bernardes e aos Irmãos Sampaio que passaram às mãos dos grupos Matarazzo e Sulamérica, culminando com o controle acionário por parte dos Vidigal do grupo Mercantil de São Paulo e dos Mesquita, proprietários do jornal O Estado de São Paulo. (BRAGUETO, 1996)
} 
de seus agentes e representantes), além é claro, do veículo de comunicação escrita mais importantes da época, o Paraná Norte, formador da opinião pública local. (ARIAS NETO, 1993, p.64).

A descrição de Miguel Arias Neto também indica a densidade da infraestrutura presente no conjunto do empreendimento. Os núcleos urbanos e principalmente Londrina foram dotados de abastecimento de água, energia elétrica, telefonia e telégrafo aumentando a densidade técnica (SANTOS, 2004) de todo arranjo espacial, fazendo avançar o meio técnico-científico e viabilizando a estruturação da economia urbana.

O capital investido pela Companhia de Terras na modernização da ferrovia, na construção das vias principais - rodovia e ferrovia - e das estradas vicinais, nas redes locais de telégrafo e telefone, foi remunerado pela efetiva valorização dos lotes ou datas, rurais e urbanas e pelo volume de vendas realizado. Esse processo de acumulação permitiu aos ingleses e seus sucessores nacionais uma ampla, vantajosa e lucrativa recuperação desses investimentos ${ }^{23}$. A Companhia, ao direcionar o processo de produção do arranjo espacial nas terras sob seu controle, soube manobrar de modo a obter vantagens econômicas significativas ampliadas pelo conjunto do trabalho social implicado na produção do espaço.

Pierre George (1969, p.92) nos lembra que, para o geógrafo, o trabalho é primordialmente o "criador de paisagem e do movimento cotidiano que caracteriza geograficamente uma região, uma cidade, um porto, um eixo de circulação" e que esta ação criadora guarda especificidades conforme se analisa sua duração:

Em escala secular ou pelo menos nos limites de tempo de uma geração, o trabalho cria uma paisagem. Em escala cotidiana, impõe o que se denominou um 'estilo de vida' que é ao mesmo tempo uma realidade geográfica, etnológica e sociológica. (GEORGE, 1969, p.93)

\footnotetext{
23 Durante a fase inglesa da CTNP, segundo Nadir Cancian (1977) a companhia obteve, apenas com a venda de lotes rurais, uma receita total de 75 mil contos de réis. A esse montante somam-se mais os 52 mil contos de lucro relativos à operação da ferrovia lançados em seu balanço de 1944 (TOMAZI, 1997, p.220) e ainda os milhares de "datas"(lotes) urbanas espalhadas no conjunto das cidades criadas nessa fase, cujo valor total não foi possível verificar.
} 
À medida que avançavam as infraestruturas redefinia-se a localização das áreas já estruturadas, conferindo-lhes centralidade, especialmente para a nascente cidade de Londrina, que paulatinamente expressava em sua paisagem o rápido desenvolvimento da divisão social do trabalho. Esse desenvolvimento foi profundamente influenciado pela configuração específica do habitat rural e pelas relações intensas entre meio rural e núcleos da rede urbana norte-paranaense em formação (FRESCA, 2004, p.49). 


\title{
1.1.3 - A produção da cidade e da situação de Londrina no contexto regional norte-parananense
}

A posição de Londrina na parte mais oriental das terras adquiridas pela Companhia de Terras foi definidora de sua função primeira: a de sediar os escritórios de vendas e o comando do processo de produção do arranjo espacial de toda área pertencente à Companhia ${ }^{24}$.

O sitio escolhido atendeu as características da topografia e da drenagem locais, proporcionando abundância de água.

\begin{abstract}
Essa localização do sítio de Londrina está ligada não somente à topografia, mas principalmente ao problema da água e à drenagem local. De fato, quando pela primeira vez se penetrou na região, estabeleceu-se o local da construção da cidade um pouco a leste do atual sítio, nas proximidades das nascentes do Córrego das Pedras. Feito depois o reconhecimento da região, verificou-se que mais no alto do espigão nasciam vários córregos, resolvendose, então, localizar a cidade nesse local, uma vez que, quer a topografia quer a presença abundante da água tornavam o sítio mais favorável. (PRANDINI, 2007, p.89)
\end{abstract}

A cidade foi, então, construída sobre o espigão que a atravessa na direção sudeste-noroeste e apresenta uma altitude média de $600 \mathrm{~m}$. Foi justamente nessa parte mais elevada da cidade que se reservaram lugares para a Igreja, a Prefeitura, o Fórum, o comércio e as residências dos funcionários mais importantes da Companhia de Terras, definindo assim o Centro Principal e algumas áreas residenciais.

O plano urbano original de Londrina é um clássico tabuleiro de xadrez, para o qual se previa o assentamento de aproximadamente 20 mil pessoas (ASARI e TUMA, 1978, p.65).

\footnotetext{
24 “Assim graças a dois fatores conjugados: - o fator geográfico, isto é: a posição geográfica privilegiada - no coração dessa riquíssima região agrícola; e ao fator histórico, isto é: o fato de ter sido o marco inicial e a sede de onde se dirigiria a colonização dessa região, Londrina já estava de antemão destinada a ter um rápido desenvolvimento e uma importância ímpar na região.” (PRANDINI, 2007,p.88)
} 


\section{Londrina: croquis da planta inicial da cidade}

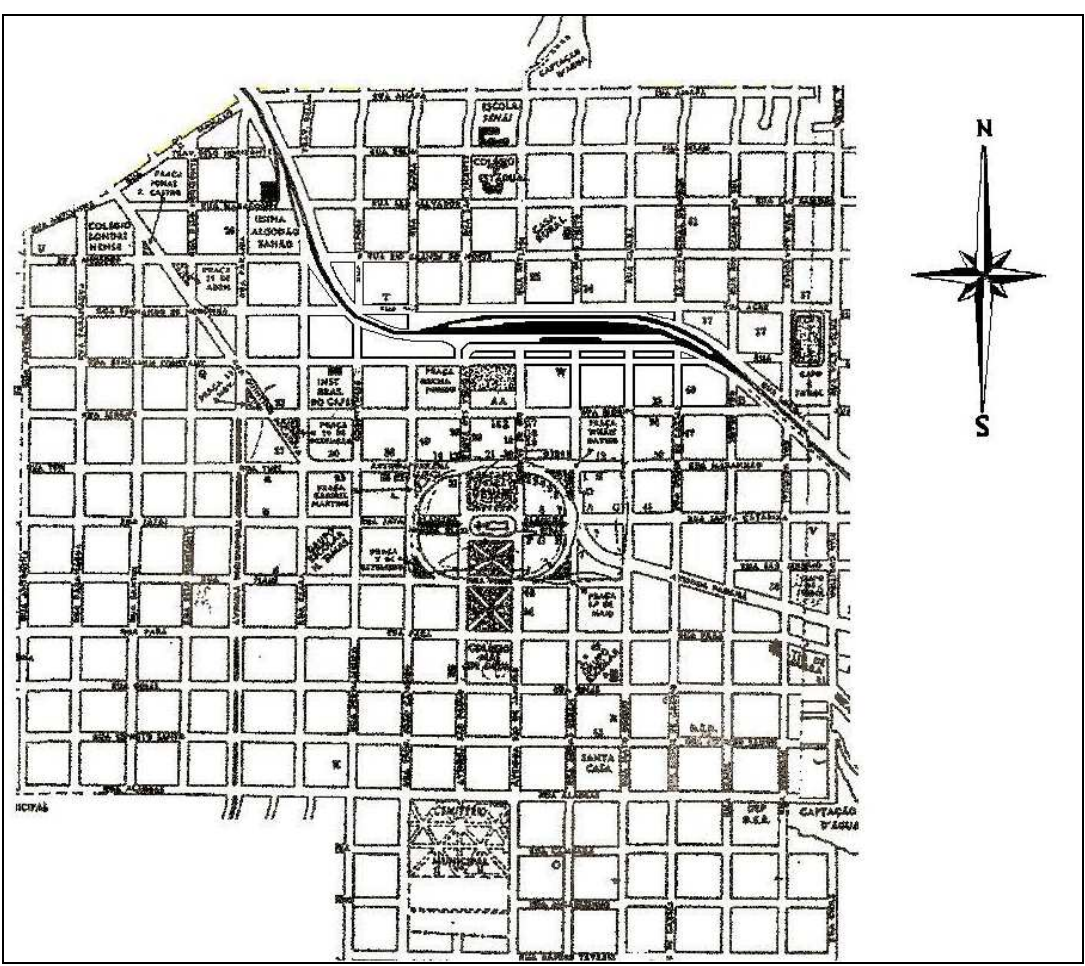

Fonte Yamaki (2003, p.43)

A forma escolhida, a despeito de sua aparente simplicidade, respondia à necessidade de articulação de todo o conjunto em escala regional.

O tabuleiro de xadrez obedecia a uma padronização de quarteirões e vias de acesso aos lotes individuais com 12 metros de largura. As quadras tinham 110 metros de comprimento, divididas em 20 ou 24 lotes urbanos. A forma da cidade é marcada, principalmente, pela penetração das vias de acesso regionais. A rodovia e a ferrovia são os componentes principais do sistema viário, devendo a primeira desenvolver-se pelo espigão central, hoje Av. Paraná (ADUM, 1991, p.110).

Ao sul da ferrovia, se desenvolveram o Centro Principal e os bairros com melhores condições urbanas, que abrigaram as elites locais. Ao norte surgiram as Vilas, ou melhor, uma boa parte delas. As Vilas se multiplicaram após 1937, ano em que teve inicio o loteamento da Vila Casoni, um dos primeiros transbordamentos do meio construído em relação ao quadrilátero original projetado pela Companhia. A partir do momento em que a conexão ferroviária se completou e que, 
simultaneamente, ocorreram as primeiras colheitas de café, a construção da cidade ganhou impulso considerável ${ }^{25}$.

O controle que a Companhia de Terras exercia sobre o espaço regional se repetia em relação ao meio urbano. O comprador de lotes urbanos tinha que obedecer a um simulacro de código de posturas definido no contrato de compra e venda, ou escrituras de compra e venda (ADUM, 1991, p.111). Proibia-se, por exemplo, a permanência de ranchos de palmito por mais de um ano, obrigando o proprietário a construir edificações de madeira ou alvenaria a partir daí. Outro item era a obrigatoriedade de permitir a execução de serviços, como canalização de água, esgoto e luz nas condições estabelecidas pelas concessionárias determinadas pelos poderes estaduais e municipais.

Em resumo, a associação entre Prefeitura e Companhia, expressa na figura do Diretor Prefeito, desenvolveu diversas ações visando à rápida consolidação do meio construído. Essa consolidação atendia aos interesses da Companhia de Terras, sobretudo em razão da valorização dos lotes urbanos e do efeito positivo que o desenvolvimento da cidade trazia para os negócios com os lotes rurais. Londrina era a "porta de entrada" e uma espécie de "cartão de visitas" da Companhia para os viajantes e potenciais compradores dos lotes à venda.

Em meados dos anos 1940 todos os lotes do quadrilátero previsto pelo plano urbano estavam vendidos e a cidade contava com 3708 edifícios $^{26}$. A população urbana segundo o Censo de 1940 era de 33.707 habitantes e já representava $50 \%$ da população total do município ${ }^{27}$. Em 1950, já eram mais de 6.000 edificações, incluindo

\footnotetext{
${ }^{25}$ Os números sobre as edificações variam conforme a fonte, mas giram em torno de 700 a 800 edificações em 1935 e 2224 prédios segundo o Censo de 1940.

${ }^{26}$ Ao que tudo indica esse número não incluiu as construções na área suburbana onde estavam incluídas as Vilas. As Vilas se multiplicaram simultaneamente a essa consolidação e valorização dos lotes situados no quadrilátero e, em 1947, já existiam 53 Vilas em Londrina.

${ }^{27}$ Segundo dados do IBGE - Censos de 1940 e 1950 - a população urbana triplicou passando de pouco mais de 10 mil pessoas em 1940 para mais de 30 mil em 1950, fazendo com que, em menos de 20 anos Londrina passasse a ser a terceira maior cidade do estado, superada apenas por Ponta Grossa e Curitiba. O município de Londrina, porém sofrera redução em seu contingente passando de 75296 hab. em 1940 para 66581 em 1950 devido aos desmembramentos de Mandaguari e Apucarana, ambos com mais de 50 mil habitantes Isso evidencia a velocidade e a intensidade da ocupação do meio rural do Norte do Paraná com base na pequena e média propriedades ao longo da década de 40 e, consequientemente, a formação de mercado consumidor importante.
} 
edifícios de vários andares. Os números indicam o rápido desenvolvimento da construção civil na cidade. Considerando o crescimento do número de edificações em alvenaria, em torno de $42 \%$ na área urbana, a existência de 96 edifícios de 2 andares e de 3 edifícios de 8 andares em construção (PRANDINI, 2007, p.95), podemos dizer que essa atividade iniciava seu processo de industrialização. Simultaneamente, persistiam atividades artesanais de construção, a exemplo das casas de madeira erguidas rapidamente nas Vilas ${ }^{28}$.

No início dos anos 1950, a Companhia de Terras, então sob a administração de representantes de grandes grupos econômicos nacionais, já não exercia um rígido controle sobre a expansão do meio construído. A cidade crescia rapidamente. Tentativas de disciplinar e manter sob controle a expansão urbana foram realizadas pela Prefeitura por meio da elaboração de legislação, ${ }^{29}$ que incidiu principalmente sobre a atividade dos loteadores e especuladores imobiliários em geral.

Entre as maiores preocupações, estava a necessidade de recursos para expandir os serviços e equipamentos urbanos. Serviços como o de abastecimento de água, saúde e limpeza urbana, menos dinâmicos em sua expansão, de manutenção custosa e operação delicada, foram iniciados pela Companhia e, até o final dos anos 1940, transferidos ao poder público municipal (LINARDI, 1995, p. 123).

Por outro lado serviços como os de transporte rodoviário intermunicipal e energia elétrica tiveram tratamentos diversos. Os serviços de transporte rodoviário intermunicipal de cargas e passageiros foram transferidos para empresários locais, que prosperaram a ponto de

\footnotetext{
${ }^{28}$ Domingos Casoni que iniciou o loteamento que deu origem à Vila Casoni e que construiu várias casas de madeira em Londrina, define o perfil dos moradores: "Não eram pessoas exigentes quanto a conforto, provavelmente acostumadas a um cotidiano de pouco conforto e muito esforço. $\mathrm{O}$ individuo comprava a data e queria um lugar para ele morar. Não havia tantas exigências. [...] Fazia uma casa de 6 por 6 (metros) e dividia em cruz, quatro cômodos. Abria-se uma porta aqui e outra lá, uma cozinha, uma sala e dois quartos. E só. No nosso caso era uma sala, um quarto e uma cozinha. Assim chamava de bico-de-pato, um puxadinho, uma meiaágua." ((IPAC-PML, 1987, p.23)

${ }^{29}$ Um exemplo foi a promulgação da Lei 133de 1951, cuja elaboração foi solicitada ao escritório do ex-prefeito paulistano o engenheiro Prestes Maia.
} 
se transformarem em uma das maiores empresas desse ramo em termos nacionais ${ }^{30}$.

O abastecimento de energia elétrica, cuja concessão, foi obtida do governo estadual em 1933, foi repassado em 1936 a dois diretores da Companhia de Terras: Gastão Mesquita Filho e Rolan Davis. A produção de energia elétrica fora iniciada a partir de equipamentos movidos a diesel. Com o acentuado aumento da demanda ao longo dos anos 1940, teve inicio a construção de usinas hidrelétricas próximas à cidade: Usina Três Bocas em 1941 e a Usina Apucaraninha em 1948. Paralelamente houve a contínua expansão dos equipamentos a diesel. A produção e a distribuição da energia elétrica em Londrina permaneceram no âmbito da iniciativa privada até meados dos anos 1970, quando esses serviços foram estatizados (RAZENTE, 1984, p.233).

A Companhia também cedeu diversas áreas para construção de hospitais, aeroporto, escolas e para a instalação de outros órgãos das administrações municipal, estadual e federal. O aeroporto, que nos anos 1950 contava com 40 vôos diários, foi importante elemento na ligação com Curitiba, São Paulo e Rio de Janeiro. Ao longo dos anos 1950 e 1960 os fluxos de passageiros e o número de pousos e decolagens do aeroporto colocavam-no entre os de maior movimento no país (NAKAGAWARA, 1972).

A telefonia, presente na cidade desde 1932, expandiu-se a partir de 1945, com a formação da Companhia Telefônica Paranaense ${ }^{31}$. Essa empresa ampliou os equipamentos e a capacidade das linhas, permitindo o crescimento do número de telefones na cidade a partir de 1947. Entretanto, a expansão da oferta de linhas telefônicas em Londrina não acompanhou a demanda (KROETZ, 1982, p.52). Essa carência de telefones ensejou a criação de uma empresa municipal: a SERCOMTEL,

\footnotetext{
${ }^{30}$ É o caso da Viação Garcia, empresa com sede em Londrina que, atualmente, está entre as 10 maiores contribuintes na arrecadação do Imposto Sobre Serviços (ISS) no município.

${ }^{31}$ Segundo Linardi (1995, p.158) o contrato foi assinado com a ITT - International Telephone and Telegraph que atuava no setor de telefonia Brasil por meio de sua subsidiária a Radional e que havia realizado a implantação do serviço de chamadas interurbanas entre Curitiba, São Paulo e Rio de Janeiro. É possível que a Companhia Telefônica Paranaense fosse de fato mais um braço da ITT no Paraná.
} 
que assumiu a operação das linhas já instaladas e expandiu o número de linhas e telefones na cidade a partir de 1968. Sob o controle da SERCOMTEL, a rede telefônica em Londrina cresceu de forma acelerada ${ }^{32}$.

A expansão das infraestruturas, particularmente das redes, equipamentos e serviços urbanos foram fatores importantes para 0 processo de centralização que permitiu a Londrina exercer papel de comando e de intermediação entre a rede urbana regional e centro industrial e financeiro do país, São Paulo.

Com expressão desse processo de centralização, Londrina adquiriu, ao longo de suas primeiras décadas de existência, uma "situação geográfica favorável" (SPÓSITO, 2001, p.627), redefinida em função das novas conjunturas, mas, sobretudo, mantida e reforçada. As novas formas de inserção de Londrina na dinâmica territorial nacional, construídas a partir dessa situação geográfica favorável, foram particularmente influenciadas pela formação de um diversificado circuito superior da economia urbana.

\footnotetext{
32 O número de telefones em operação mais do que dobrou em apenas um ano, saltando de 2.900 em 1968 para 7.130 em 1969 (LONDRINA, 1987, p. 26).
} 


\section{2 - A Cafeicultura e a economia urbana em Londrina}

A cafeicultura paranaense se consolidou ao longo da década de 1940, quando os preços internacionais do café se elevaram significativamente, a industrialização nacional atingiu patamares mais elevados de integração setorial e um novo cenário internacional começou a se formar. Claudio R. Bragueto (1996) sintetiza a ligação entre o desenvolvimento da cafeicultura na região de Londrina e as novas condições do período e da urbanização brasileira:

É neste contexto, marcado pelo deslocamento do eixo econômico
para o setor industrial, porém, com o setor cafeeiro representando
papel fundamental na geração de divisas para o país, logo,
demandando e recebendo um tratamento diferenciado no que se
refere às políticas econômicas, que a Microrregião Geográfica de
Londrina vai ser incorporada como uma frente pioneira da
expansão cafeeira, se integrando organicamente a São Paulo, e se
constituindo também em fornecedor de produtos alimentares e
produtos industrializáveis àquele pólo nacional, assim como se
convertendo em um importante mercado para os seus produtos
manufaturados. (BRAGUETO, 1996, p. 116)

A inserção de Londrina na divisão de trabalho se manteve em seus traços básicos definidos, em boa mediada, pelo arranjo espacial produzido no contexto do processo de colonização dirigida. No entanto, essa inserção ganhou outra dimensão, outra espessura. Essa nova dimensão se expressou nos novos fluxos e fixos ligados à cafeicultura, a qual, como forma concreta da especialização regional que caracterizou o Norte do Paraná entre meados dos anos 1940 e meados dos anos 1960, foi determinante para a constituição dos embriões dos circuitos da economia urbana em Londrina.

É importante frisarmos que, localmente, por conta da fertilidade natural do solo, da estrutura agrária e das relações de produção vigentes, a cafeicultura significava um conjunto de práticas no âmbito da pequena produção mercantil: em especial o uso do solo agrícola e técnicas de cultivo intensivas em mão-de-obra e a comercialização de parcelas expressivas dessa produção. Ao longo de quase três décadas, houve estreita associação entre o cultivo do café e o de milho, feijão, 
arroz, e outros gêneros agrícolas, geralmente denominados "culturas intercalares". O conjunto da produção regional era realizado em pequenas propriedades que contavam com pouco ou nenhum recurso técnico.

As pequenas explorações, conseqüentemente as pequenas e
médias propriedades, dado o pouco capital de que seus
proprietários dispunham não conseguiam realizar o suficiente para
a montagem de quaisquer aparelhamentos ou máquinas de
beneficiamento (CANCIAN, 1977, p. 270, 271).

O baixo grau de tecnificação associado à pequena propriedade foi um dos fatores responsáveis pela densidade de relações entre pequenos produtores mercantis e uma verdadeira rede de intermediários urbanos que, a partir dos anos 1950, estabeleceu vínculos com grandes firmas exportadoras e grupos industriais instalados em Londrina (PAYES, 1984). Essa divisão de trabalho na escala local, interna à cafeicultura norte-paranaense, produziu efeitos consideráveis sobre a estruturação do circuito superior da economia londrinense. 


\subsection{1 - A Cafeicultura e o contexto da formação do circuito superior embrionário}

Do ponto de vista da circulação do excedente econômico gerado pela produção agrícola, as cidades, em especial Londrina, abrigavam várias ações inerentes ao processo de valorização do café e assim realizavam a captura urbana da renda agrícola. Nakagawara (1972, p.88) que analisou os papéis de Londrina como centro regional no período de maior expansão da cafeicultura, explicita esse processo:

O produtor de café entrega, geralmente, seu produto em 'coco' ao 'maquinista' ou a uma cooperativa - que o beneficia, padroniza, e entrega às firmas exportadoras. Dependendo de certas contingências do mercado, o café é entregue, depois de beneficiado e padronizado ao IBC. De acordo com os estímulos de preços ou solicitação do mercado, o café, após ser beneficiado, passa muitas vezes por processos de "liga", padronização e seleção com o emprego de balões de liga e máquinas seletoras eletrônicas, num processo complexo que envolve grande número de operações comerciais que se constituem em fator de grande dinamismo da fase de comercialização desse produto.

Também Linardi (1995,p.105) insiste que na região havia uma intensa participação urbana no processo de comercialização da produção agrícola. A autora destaca a relação entre pequenos produtores e maquinistas e também as relações dos primeiros com comércio e serviços locais:

O acesso ao centro comercial era necessidade vital do pequeno produtor desta região, pois contrariamente ao grande produtor de grandes safras, que as comercializava em grandes centros, como São Paulo e Santos, esses pequenos agricultores levavam suas safras para as cidades, onde as vendiam para os intermediários no caso, os maquinistas - que por sua vez as vendiam nas cidades maiores, para representantes de casas exportadoras. Em geral o pequeno produtor também gastava suas economias naqueles mesmos centros urbanos, comprando o necessário para completar os itens básicos de sua subsistência.

A mesma situação é descrita por outro autor, Payes:

Uma vez colhido e seco, o café era armazenado nas tulhas, quando então o produtor simples, juntamente com o parceiro dirigiam-se às várias empresas que realizavam o beneficiamento, chamadas comumente de maquinistas que se instalaram desde a segunda metade dos anos 30 no Norte do Paraná. Referimo-nos ao pequeno maquinista local, que radicou nos patrimônios e pequenas cidades por excelência e que representou o primeiro intermediário na 
cadeia de comercialização do café, embora nas décadas de 30 e 40, também adquirí-se o excedente de mantimentos. Com efeito, a produção agrícola era inicialmente canalizada por estes maquinistas que negociavam com milhares de produtores simples, parceiros, empreiteiros, colonos, etc. espalhados pelo Norte do Paraná, notadamente no Norte Novo e Norte Novíssimo (PAYES, 1984, p.113).

\section{O café passava por vários intermediários até ser exportado} o que fazia subir seu preço. Os pequenos produtores se viram enredados numa trama de intermediações urbanas, a qual Ihes drenava parte significativa dos excedentes gerados em suas pequenas propriedades ${ }^{33}$. Sujeitos aos imprevistos provocados pelas geadas e tendo que arcar com as parcelas de pagamento de sua propriedade ou as da compra de uma nova data ${ }^{34}$, os pequenos produtores não contavam com acesso a crédito nos bancos. Os que pretendiam realizar alguma benfeitoria em sua casa, nas edificações de seu sítio ou que fossem atingidos por algum imprevisto recorriam aos maquinistas que exerciam também a função de fornecedores de empréstimos ou intermediários no contato com os bancos $^{35}$. Como contrapartida dessa intermediação o lavrador ficava comprometido com o maquinista por meio de notas promissórias. Quando ia negociar sua colheita, o lavrador se via submetido a um determinado maquinista que fazia uso de sua posição vantajosa na hora de combinar os preços ${ }^{36}$.

\footnotetext{
${ }^{33}$ A descrição de alguns procedimentos das primeiras etapas de comercialização das safras pode esclarecer um pouco essas relações. Para efetivar a compra o maquinista recebia uma amostra do café que passava por duas provas: peso ou a "renda" e a classificação da bebida. A primeira prova correspondia a operação de estabelecer quanto uma saca de café em coco renderia em termos de café beneficiado. Retirava-se uma amostra de $100 \mathrm{~g}$ que passava pelas operações de beneficiamento (descascar e limpar o grão) e que ao final era novamente pesada. Em média uma saca de $40 \mathrm{Kg}$ de café em coco rendia de 18 a $22 \mathrm{Kg}$ de café beneficiado (PAYES, op. cit., p. 114). A segunda prova consistia em torrar alguns grãos e produzir um pouco de bebida para verificar o sabor e a ocorrência ou não de algum problema. A partir daí havia a negociação sobre o preço do lote de café, sobre o qual incidia o imposto sobre vendas e consignações e também o "carreto", ambos por conta do produtor. Os problemas apareciam quando havia discordância quanto ao preço, especialmente em relação a questão da renda, pois essas informações eram facilmente manipuladas pelos maquinistas. Mas para os pequenos produtores não havia muitas opções. Poderiam até procurar outros maquinistas, mas, muitas vezes essa opção não existia. Havia outros vínculos entre maquinistas e produtores que impediam esse grau de liberdade, a exemplo dos adiantamentos e o aval à empréstimos que atrelavam os produtores a determinados compradores.

${ }^{34}$ Nome local dado a lotes de terra de pequenas dimensões.

35 "Os maquinistas realizavam adiantamentos e, principalmente, se apresentavam como avalistas nos pedidos de empréstimo encaminhados por eles junto aos bancos particulares" (PAYES, 1984, 115).

${ }^{36}$ Outra estratégia usada pelos maquinistas era fixar os preços de compra da safra antecipadamente, no momento da tomada do empréstimo. Assim poderiam embolsar quantias razoáveis em função das eventuais altas de preços do café no momento de venda de seus próprios estoques para atacadistas.
} 
Por sua vez, os pequenos maquinistas que estabeleciam relações de subordinação com os pequenos produtores, também passavam por dificuldades ao negociar com as grandes empresas atacadistas situadas em Londrina ou Maringá, ou até mesmo com o Instituto Brasileiros do Café (IBC). Apenas as grandes empresas tinham possibilidades de acesso às infraestruturas de exportação (locais de armazenagem nos portos, acesso a vagões de carga nas composições ferroviárias, etc.). Também mantinham certo controle sobre os equipamentos e estruturas de classificação dos cafés. Uma classificação mais detalhada permitia ganhos maiores na comercialização, ao separar o produto de melhor qualidade. Vender o produto de melhor qualidade no momento certo e nas quantidades exigidas pelos compradores internacionais era fonte de lucros adicionais paras as grandes empresas.

Com os preços em alta e a reestruturação da economia mundial, diversas firmas de grande porte ligadas ao comércio de produtos agrícolas se instalaram em Londrina de onde comandaram a comercialização e o transporte desses produtos.

Londrina é hoje importante centro de comércio, sendo que suas
relações comerciais são feitas quase exclusivamente com São
Paulo. Há em Londrina, importantes firmas comerciais e
representantes de firmas de São Paulo que compram café, arroz,
feijão, milho, algodão, mamona, etc. e, depois de beneficiá-los,
vendem-nos a grandes firmas de São Paulo. (BERNARDES, 1945,
p. 28 apud PAYES, 1984, p.107)

Ao longo dos anos 1950 empresas como a American Coffee and Tobaco, Anderson Clayton, SANBRA, Almeida Prado, Neumann Gepp, Braswey S/A entre outras, instalaram-se em Londrina onde concentravam os grandes negócios em torno da produção regional. Segundo Nakagawara (1972) Londrina era então o maior centro de comercialização de produtos agrícolas do Paraná e o Norte do estado era a região responsável pela maior parte da produção agrícola: café, algodão, menta, rami, etc. O principal produto, porém, era o café. 
Estão instaladas em Londrina grandes compradores e exportadores desse produto. O maior volume de negócios é feito pelas empresas exportadoras radicadas em Londrina, com matriz em Santos, São Paulo, Rio de Janeiro e Vitória, muitas vezes, empresas de estrutura comercial internacional, comercializando vários produtos em diversos países do mundo. (NAKAGAWARA, 1972, p.87)

No final dos anos 1960 a cidade contava com 25 filiais de grandes empresas exportadoras. A presença dessas empresas, associada à importância dos fluxos inerentes à cafeicultura, suscitou a constituição de novas infraestruturas, a expansão das já existentes e ampliação das atividades econômicas de um modo geral. Um bom exemplo foi a implantação de terminais do sistema Telex na cidade, já no final dos anos 1960. Em virtude da dependência do conhecimento das cotações na bolsa de Nova Iorque para a comercialização do café, as empresas exportadoras empregavam o sistema telex de comunicação, para efetivar seus negócios (NAKAGAWARA, 1972, p.123).

Além das empresas estrangeiras havia mais de 15 maquinistas $^{37}$ que compravam e vendiam café e mais 150 corretores inscritos no sindicato de corretores ${ }^{38}$ de café, dos quais 100 residiam na cidade. A renda gerada pelo café passou a permitir um fluxo monetário mais intenso na região. Diversos bancos vieram se instalar em Londrina desde 1937, quando a Caixa Federal inaugurou sua filial e foi logo seguida pelo Banco Noroeste. No inicio dos anos 1950 o Norte do Paraná reunia mais de 60\% das 157 agências bancárias do Estado e Londrina, com 11 agências, era a cidade norte-paranaense com maior concentração desses estabelecimentos $^{39}$. Nos anos 1970, o número de agencias bancárias na cidade subira para 26, fazendo com que Londrina permanecesse como a

\footnotetext{
${ }^{37}$ Segundo Zucker (1989, p.40) 16 maquinistas estavam instalados em Londrina nos anos 1950. Alguns deles eram nomes conhecidos na cidade por atuarem em outros negócios também tais como bancos, industrias, hotéis, construção de edifícios, etc. Alguns exemplos seguidos do ano de instalação na cidade: José Bonifacio e Cia 1937; Barros e Filho - 1941; A. Maluf - 1945; Simões e Martins e Cia - 1946; Mariucci e Fernandes - 1947; Neman Sahão - 1948; Felix Ralto - 1950.

${ }^{38}$ Segundo Nakagawara (1972) os corretores se reuniam na "pedra" local situado na esquina das avenidas Paraná e Rio de Janeiro no Centro de Londrina, onde ocorriam especulações em torno do café e também do preço das terras.

${ }^{39}$ No final dos anos 1940 estavam presentes na cidade bancos de atuação nacional e internacional como: Banco do Brasil, Banco Brasileiro de Descontos, Banco de São Paulo, Banco do Comércio e Indústria de São Paulo, e o Banco Brasileiro para a América do Sul.
} 
segunda cidade do Estado com mais agências, superada apenas por Curitiba.

Além do número expressivo de agências os fluxos bancários eram volumosos. No início dos anos 1950, a filial da Caixa Federal na cidade era responsável por $57 \%$ dos depósitos e aplicações de todo Paraná. O departamento de crédito da agência do Banco do Brasil estava entre os mais ativos do país, sendo superado apenas por São Paulo, Santos e Porto Alegre (LINARDI, 1995, p. 145).

Os maiores financiamentos destinavam-se à comercialização do café. A safra de café, comercializada nos meses de julho e agosto, trazia para cidade recursos consideráveis e as exportadoras requeriam empréstimos para comprá-la. A movimentação bancária crescia nesses períodos e os maiores negócios no comércio e na cidade em geral eram também feitos nessa época. Em menor escala, isso também ocorria com a safra de algodão e trigo. Segundo Nakagawara (1972, p.133) "em termos globais, cerca de $55 \%$ dos empréstimos se destinaram para à atividade agrícola, sendo o restante distribuído entre comercio, indústria e outras atividades."

No final dos anos 1960, a cidade havia se tornado um importante centro de decisões bancárias abrigando inspetorias regionais. As inspetorias regionais exerciam funções de orientação das agencias quanto a funcionários, operações de crédito, suprimento de caixa, constituindo uma descentralização relativa da autoridade da matriz (NAKAGAWARA, 1972, p.129).

O rápido crescimento da cidade passou a exigir serviços mais complexos tanto àqueles ligados as atividades rurais, a exemplo da agência e depósitos do IBC, a sede regional da Central de Classificação de Algodão e diversos classificadores de cereais, como também de serviços de informação, radiodifusão, médico-hospitalares, clínicas, escolas e universidades.

A trajetória do jornal Folha de Londrina que se transformou em um "verdadeiro representante da indústria da comunicação através da 
contratação de jornalistas profissionais e adquirir equipamentos de última geração" (ARIAS NETO, 1993, p.201) indica as possibilidades inerentes ao dinamismo da economia e do modo de vida urbanos.

O jornal e as nove emissoras de rádio, bem como a emissora de televisão instaladas na cidade até meados dos anos 1960, viabilizaram-se economicamente, em boa medida porque souberam explorar as possibilidades de divulgação e propaganda decorrentes da diversidade de atividades que constituíam a economia urbana de Londrina e também da região (ARIAS NETO, 1993).

Os serviços de saúde também ganharam projeção com a multiplicação de hospitais e clínicas particulares com profissionais especializados. No final dos anos 1960 havia em Londrina 8 hospitais com 906 leitos, ou seja, 3 leitos para cada 1.000 habitantes. Quanto aos médicos havia cerca de 200, das mais diversas especialidades (NAKAGAWARA, 1972, p.237). As clínicas especializadas eram responsáveis pela atração de pessoas em volume superior ao dos hospitais. Havia 4 laboratórios, sendo que um deles, o instituto de patologia do Norte do Paraná, possuía equipamentos de ultima geração, só encontráveis em algumas capitais brasileiras (NAKAGAWARA, 1972, p.239). Esse laboratório analisava material recolhido de Cornélio Procópio à Apucarana, ou seja, em um raio de $70 \mathrm{~km}$ ao redor de Londrina.

A elevação do padrão médico e do crescimento da influência de Londrina estava ligada à criação do curso de medicina na Universidade Estadual de Londrina (UEL) em 1967.

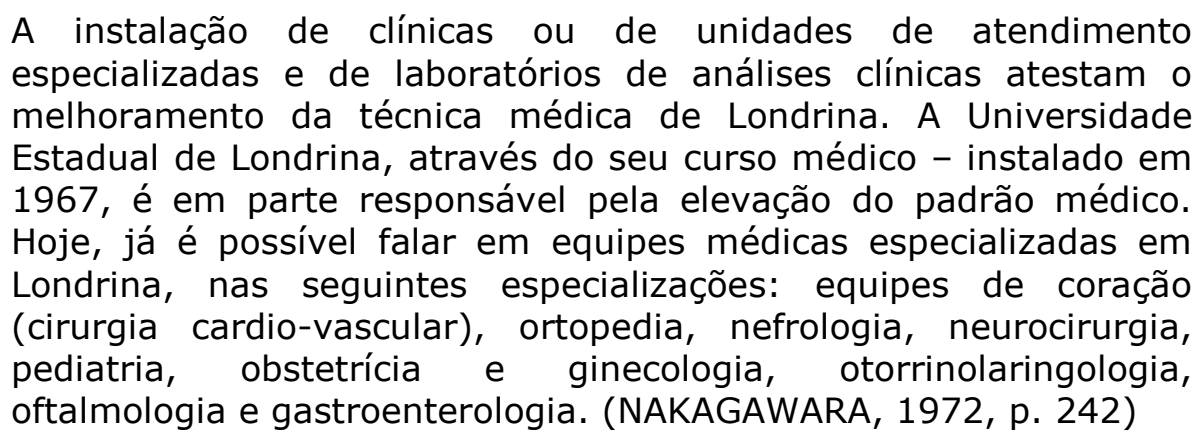


Como podemos ver, a cidade ampliou sua centralidade derivada, inicialmente, de todo conjunto de atividades que constituíam os circuitos de produção, beneficiamento, classificação, estocagem, transporte e comercialização do café. Ao longo do tempo o processo de concentração de infraestruturas, a exemplo da ferrovia, das estradas asfaltadas, da telefonia, telégrafo, telex que materializavam as conexões com o centro dinâmico da economia brasileira e com mundo, reforçaram a polarização que Londrina exercia sobre um vasto espaço regional. Essa polarização incrementou os fluxos de pessoas, mercadorias e dinheiro que se dirigiam para Londrina e fez com que outros serviços e atividades crescessem e ganhassem importância.

Um exemplo claro é o do desenvolvimento de forte aparato comercial e de serviços ligado aos fluxos de viajantes. Segundo Prandini (2007, p.108) havia 70 estabelecimentos do tipo pensões, hotéis e restaurantes de todas as categorias com um movimento extraordinário, justificado pelas mais de 5.000 pessoas em transito diários pelas ruas da cidade. As casas atacadistas "com filiais em diversas cidades a oeste de Londrina" (PRANDINI, 2007, p.107) também revelavam a importância da cidade em termos regionais.

Algumas firmas comerciais de Londrina, principalmente as
pequenas e localizadas nas áreas suburbanas ou rurais são bons
clientes. Os compradores que residem fora de Londrina são
geralmente pequenos comerciantes, estabelecidos em vilas,
povoados ou cidades. Em caso de emergências as grandes firmas
de Londrina também se abastecem nesses atacadistas[...]
O auge do comércio atacadista de Londrina foi durante a década
de 50 até o início de 60 . Tem havido uma regressão relativa em
termos de volume de vendas, coincidindo esse fato com o
melhoramento ou a pavimentação das estradas que servem as
cidades mais populosas que se alinham em torno do espigão de
penetração por São Paulo. Com o melhoramento das estradas e
linhas de ônibus mais freqüentes para a capital paulista, houve
também uma entrada gradativa e crescente dos viajantes das
firmas paulistas, oferecendo os produtos a menor preço e
diretamente da fonte produtora. (NAKAGAWARA, 1972, p.68)

Segundo Nakagawara (1972) os maiores atacadistas em Londrina eram empresas provenientes de São Paulo e outros estados, tais como: J. Alves Veríssimo, Dias Pastorinho, Dias Martins, Importadora São 
Marcos e Importadora São Remo. O impulso dado à economia urbana londrinense pela produção de café atraiu novos empreendimentos comerciais varejistas para Londrina ${ }^{40}$. É o caso da família Fuganti que, vinda de Rio Grande do Sul, havia acumulado experiência no comércio em cidades que, a exemplo de Londrina, mantinham intenso relacionamento comercial com São Paulo. Em 1946, a empresa da família foi reorganizada, abrigando filhos e netos do fundador e diversificando seus empreendimentos.

Ao suceder o pai, o comendador Julio Fuganti deslocou 90\% dos
bens e lojas da sociedade para o Norte do Paraná. A firma
progrediu extraordinariamente e chegou a constituir os seguintes
estabelecimentos: Plenogás Fuganti (usina de engarrafamento e
entrega de gás), Plenolar Fuganti (móveis e utilidades
domésticas), Supermercado Fuganti, S. A. Mercantil,
Administradora e Imobiliária, Cia Agrícola Pecuária Irmãos Fuganti,
Transportes Rodobrás S. A. (transporte de gás entre Santos e
Londrina), e Rotec S. A. - concessionária FNM e DKW (adquirida
em 1970); distribuídas por diversos municípios do Paraná, como:
Londrina, Apucarana, Arapongas, Rolândia, Maringá e Curitiba. A
firma foi chamada de "símbolo do comércio londrinense" com a
abertura da Distribuidora de Gás Plenogás em 1955 e a Imobiliária
Fuganti em 1959, além de outros empreendimentos (BLUM, 2006,
p.71).

A diversificação do campo de ação do capital dessa família é indicativa das possibilidades e do dinamismo econômico gerado tanto pela nova conjuntura do país no pós-guerra como pelos efeitos combinados da cafeicultura e do arranjo espacial na região de Londrina. No caso da família Fuganti, o capital comercial originário do varejo, expandiu-se para o fornecimento de gás, transporte, produção agropecuária, especulação imobiliária com lotes rurais e urbanos, ampliando a divisão social do trabalho na cidade e na região e os nexos entre cidade e campo e entre cidades na conformação da rede urbana regional.

A intermediação na distribuição de bens e serviços exercida por Londrina em relação ao conjunto de cidades da região deixa evidente

\footnotetext{
${ }^{40}$ O Comércio varejista em Londrina se desenvolveu de forma acentuada desde meados dos anos 1930. Nesse período a cidade já contava com grandes estabelecimentos comerciais como: a loja da família Dequech, as Casas Pernambucanas, a Casa Combate entre outras que vendiam uma grande variedade de itens. Nesse período o comércio varejista atendia, sobretudo, a demanda local dos pequenos proprietários que iam se instalando, assim como as necessidades dos primeiros moradores da cidade.
} 
a centralização dos fluxos econômicos na cidade (NAKAGAWARA, 1972). Essa centralização e as necessidades de consumo de um número crescente de comerciantes, profissionais liberais, funcionários públicos, funcionários mais graduados da Companhia de Terras sustentavam a sofisticação do terciário instalado na cidade. O salão de chá ${ }^{41}$ instalado no edifício da casa Fuganti é um exemplo da sofisticação permitida pela dinâmica da economia urbana:

A Casa de Chá estava instalada em um amplo salão de cores claras, móveis finíssimos, luminárias de cristal, com fundo musical clássico. Bebia-se sucos, refrescos, refrigerantes, uísque (menos cerveja), chá da Índia, chá mate e café. As tortas e bolos eram preparados por uma senhora alemã e os sorvetes eram preparados por um sorveteiro recém chegado da Itália. No período vespertino o salão era freqüentado por senhoras da sociedade e a noite, por gerentes de banco, médicos e homens de negócio. A revista $O$ Globo de Porto Alegre chegou a publicar uma reportagem dizendo que "no meio da sujeira e do pó tinha um salão de chá a altura de uma capital" (IPAC, 1995, p. 236,237).

A Casa Fuganti tinha feições de loja de departamentos relativamente precoce. Nos seus três pavimentos estavam distribuídos setores diversos que reuniam produtos como: roupas masculina e feminina, perfumes, tecidos, armarinho, móveis, prataria e eletrodomésticos (fogões, geladeiras, máquinas de lavar), além de mercearia e da venda de gás liquefeito (BLUM, 2006, p.73). O conjunto de dados que a descrição desse estabelecimento permite reunir, mostra a complexidade da nascente economia urbana de Londrina.

Analisada do observatório particular da estruturação dos circuitos da economia urbana, fica patente que Londrina viabilizou a reunião e a combinação de diferentes tipos de trabalho e de trabalhadores: da sofisticação da doceira alemã e do sorveteiro italiano à simplicidade dos entregadores com carroça, dos ajudantes de cozinha e de limpeza, dos vendedores e vendedoras, entre outras. Todas essas formas de trabalho foram diretamente subordinadas à reprodução de capitais, nesse caso de tipo mercantil, que encontraram na cidade e na região oportunidades de valorizarem-se.

\footnotetext{
${ }^{41}$ A implantação de um salão de chá parece indicar certa influência da cultura britânica na cidade.
} 
A função comercial de Londrina se destaca não só pelo seu equipamento, como principalmente pela variedade e qualidade dos produtos a venda. Verifica-se dia a dia, maior especialização do comércio londrinense, desde produtos das primeiras necessidades até aos mais sofisticados (NAKAGAWARA, 1972, p.54).

Consoante Nakagawara (1972), a maioria dos 4.500 varejistas existentes em 1970, havia se instalado na cidade nos anos 1950, ou seja, no período de maior dinamismo da cafeicultura. 


\subsection{2 - A Cafeicultura e o contexto da formação do circuito inferior embrionário}

A rigor durante o período da cafeicultura, é muito difícil e até mesmo impróprio apontarmos a existência de um circuito inferior orgânica e sistematicamente entrosado na economia urbana em Londrina. É possível apenas fazer referência a alguns elementos dispersos, verdadeiros embriões, que ainda não tinham condições plenas de desenvolvimento.

Um dado fundamental para essa argumentação é a proporção da população rural que até os anos 1960 abarca mais de $40 \%$ da população de Londrina. Essa proporção começa a se modificar de forma mais acentuada entre os anos 1960 e 1970, quando a cafeicultura deixa paulatinamente de ser a principal atividade da região.

Gráfico 1

Londrina: evolução das populações rural e urbana, 1950 a 1970

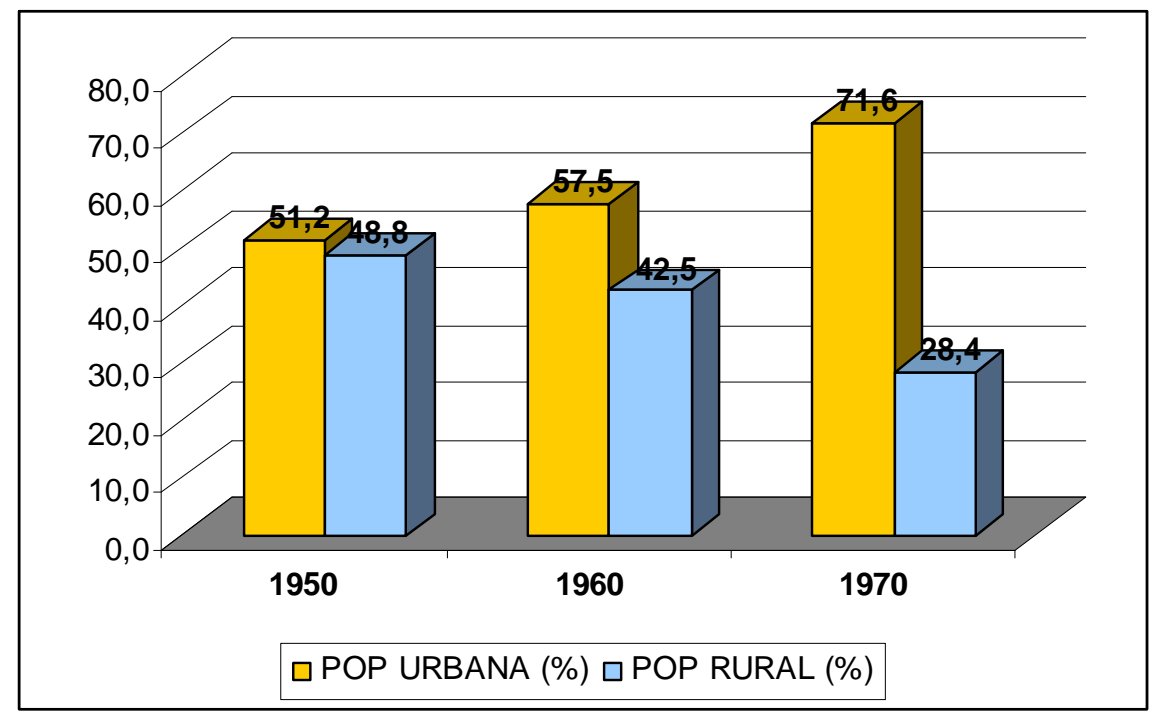

Fonte: IBGE, Censos Demográficos.

Durante o período da cafeicultura a economia urbana londrinense se desenvolveu a partir de uma base rural, composta por pequenos produtores, colonos, parceiros e toda gama de relações de produção implicadas no cultivo do café e de outros produtos associados. Essa base rural era complementada por uma intrincada teia de relações entre pequenos maquinistas, grandes exportadores, fazendeiros envolvidos em diversas etapas do processo de comercialização e 
valorização do café (beneficiamento, classificação, armazenagem, etc.), que constituíam a parcela urbana da divisão do trabalho local. Mantendo relações diretas e indiretas com essa parcela urbana da cafeicultura estavam os bancos, o comércio, a especulação imobiliária, os serviços e as demais atividades urbanas.

A indústria começou a crescer em Londrina partir dos anos 1960, período em que "ocorre o maior número de implantações de indústrias na região, voltadas não somente para um mercado regional, mas também para o mercado nacional e externo" (CESÁRIO, 1978, p.41). Até então a cidade contava apenas com as máquinas de beneficiar cereais, algumas oficinas de conserto de caminhões e automóveis e pequenas produções artesanais de instrumentos agrícolas e de materiais de construção.

\section{Gráfico 2}

Londrina: evolução do número de estabelecimentos

da indústria, comércio e serviços, 1950 a 1970

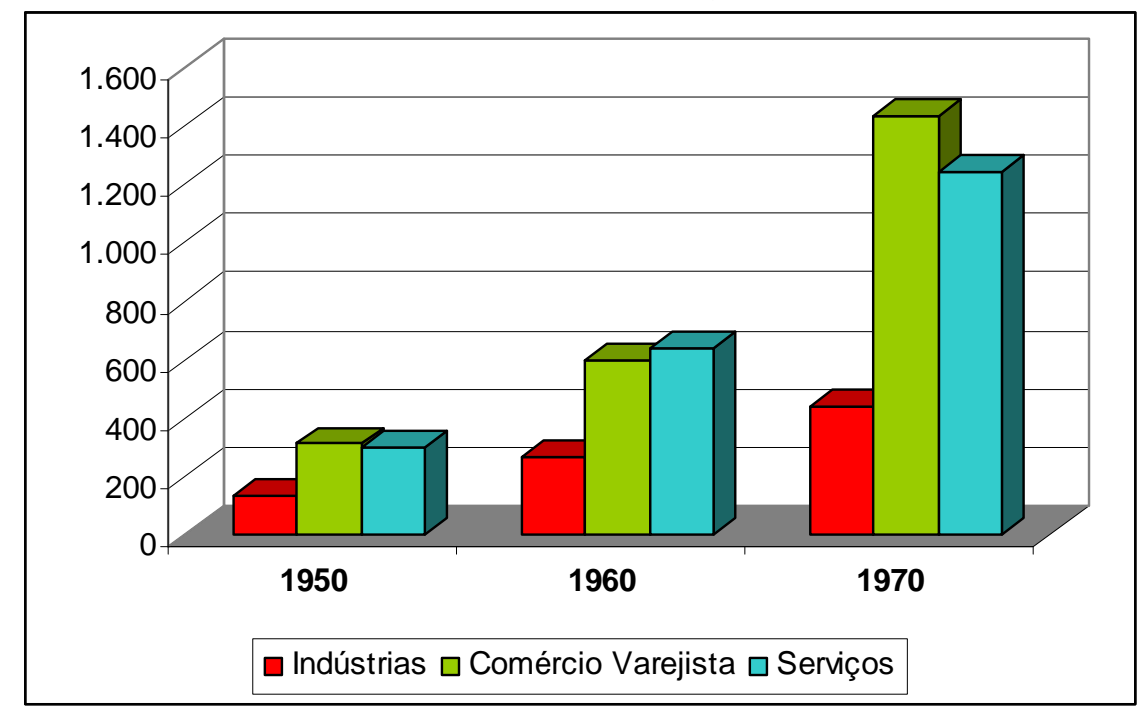

Fonte: IBGE, Censos Econômicos.

Além de um pequeno número de estabelecimentos, a participação das atividades industriais, associada à grande participação da agropecuária e extrativismo na composição da população economicamente ativa indica que, até o inicio dos anos 1970, a dinâmica da reprodução social ainda estava muito ligada ao meio rural. Essa situação começou a mudar com a modernização da agricultura e a intensificação das migrações rural-urbanas, no final dos anos 1960. 


\section{Gráfico 3 \\ Londrina: população economicamente ativa por setores de atividade $^{42}, 1960$ e 1970}

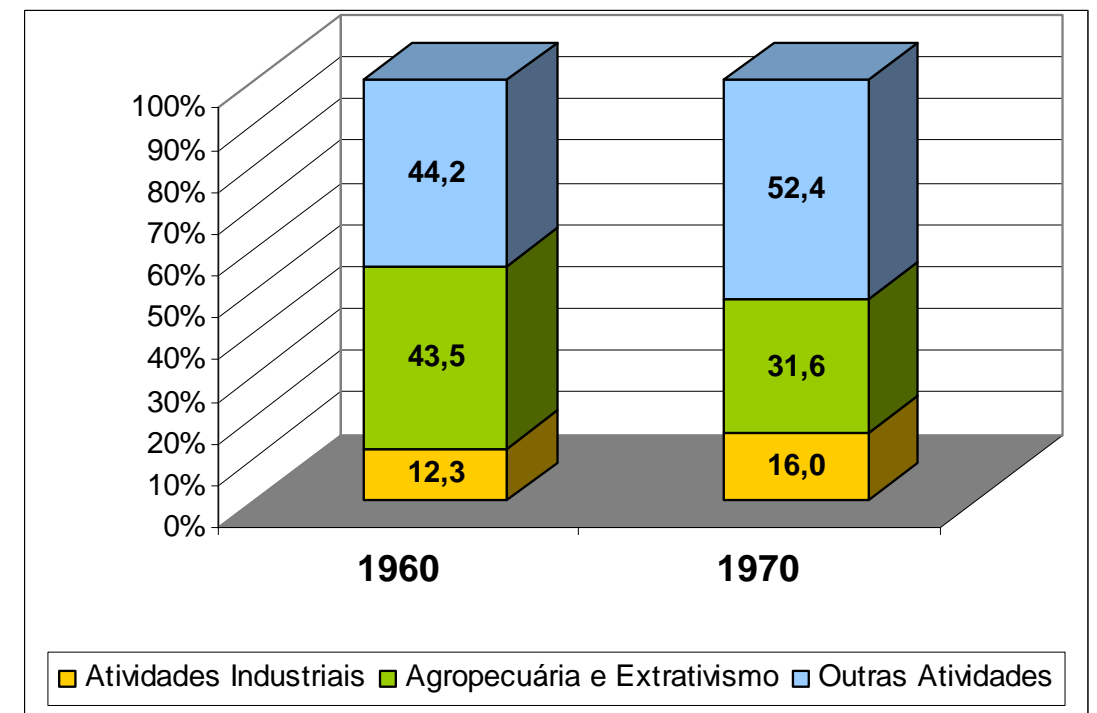

Fonte: IBGE, Censos Demográficos

A formação do circuito inferior depende das demandas não atendidas de uma numerosa população pobre com rendimentos insuficientes e/ou intermitentes concentrada nas cidades, combinada à difusão de relações salariais e à formação de classes médias.

Em Londrina, até o final dos anos 1960, quase metade da população economicamente ativa estava concentrada no meio rural, mesmo considerando que o terciário representasse uma parcela importante das oportunidades de trabalho o dinamismo econômico da região ainda era proveniente do meio rural ${ }^{43}$. A hipótese de que as condições para a formação do circuito inferior em Londrina ainda não estavam plenamente atuantes até os anos 1960 pode ser fundamentada não pela ausência de pessoas com carecimentos, mas pela dispersão a que estavam submetidos os pobres, que ainda não eram marcadamente urbanos $^{44}$.

\footnotetext{
${ }^{42} \mathrm{O}$ item atividades industriais inclui construção civil, serviços industriais de utilidade pública e a indústria de transformação. O item outras atividades inclui atividades terciárias privadas e públicas

${ }^{43}$ Esse argumento pode ser verificado indiretamente pelo enorme impacto que a introdução da soja, do trigo e da mecanização e a expansão da pecuária produziram sobre a população rural, provocando sua drástica redução e desmantelando relações de trabalho rurais como o colonato e a parceira.

${ }^{44}$ Segundo Quícoli (1984, p.26) que estudou a formação da Vila Nova situada na porção norte do Centro Principal de Londrina, essa Vila era o local de residência de operários da Companhia de Terras e de diversos carroceiros. Inicialmente os terrenos onde a Vila Nova se formou eram destinados às chácaras que forneceriam hortifrutigranjeiros para os moradores da cidade. Na prática boa parte desses terrenos foi alugada como pasto
} 


\subsection{3 - Os elementos dispersos de um circuito inferior embrionário}

A concentração de riqueza em Londrina trazida pela cafeicultura se fez acompanhar da intensificação do processo de urbanização. A partir dos anos 1950, a população urbana superou ligeiramente a população rural. Essa diferença foi ainda maior no início dos anos $1960^{45}$. Na medida em que a concentração da população na cidade crescia, aumentavam também as expressões da pobreza e da miséria no meio urbano.

O movimento da cidade era fervilhante, e o espetáculo da modernidade era registrado de maneira incansável pelos jornais, livros comemorativos, discursos, etc. Um censo seguia o outro sempre marcando o crescimento dos números do progresso; edificações, números de passageiros, movimento da rodoviária, do aeroporto, da produção de café, etc., salientando sempre o crescimento e a riqueza da "cidade menina"...

Todo esse movimento do "moderno" e do "progresso" mostrava um dos lados da questão. A seu lado caminhava a "barbárie". Junto dos prédios modernistas, uma profusão de novos bairros periféricos, sem nenhuma infraestrutura, bem como a proliferação de espaços decaídos da cidade, causavam um "mal-estar na civilização". A contrapartida dos marcos arquitetônicos modernos era, portanto, a grande quantidade de homens que chegava e se alojava em espaços periféricos, ou se amontoava em espaços "decaídos".

Os números que se contavam, no caso, eram os a "barbárie" de mendigos por metro quadrado, vadios, prostitutas, prostíbulos, pocilgas, pobreza, etc. (ADUM, 1991, p.158-162).

Outra expressão da pobreza em Londrina eram as Vilas. Segundo Neide Prandini (2007, p.94) em 1947 havia 53 Vilas em Londrina que eram um "problema urbanístico para a cidade". Essas extensões irregulares do meio construído não possuíam as mesmas condições da parte da cidade construída pela Companhia de Terras. O traçado era irregular e faltavam a infraestrutura e os equipamentos urbanos: redes de água, luz, esgoto, escolas, postos de saúde. Mas, as datas (lotes)

para animais de trabalho da Companhia. Assim conviviam numa mesma parte da cidade a Vila, os terrenos destinados ao pasto dos animais e algumas chácaras. Os carroceiros da Vila Nova aproveitavam os pastos alugados pela Companhia para tratar de seus animais e parte dos terrenos das chácaras para tratar dos animais que puxavam suas carroças (QUICOLI, 1984, p.33). Com esses animais realizavam transportes de todo tipo e fazia até mudanças, transportavam principalmente pessoas e mercadorias que chegavam à estação de trem.

${ }^{45}$ Conforme nos mostra o gráfico 1 . 
localizadas nas Vilas eram mais baratas e, portanto, mais acessíveis do que aquelas situadas em outros loteamentos da cidade.

Em meados dos anos 1950 havia 88 vilas espalhadas pela periferia de Londrina, especialmente nas zonas norte e oeste (LINARDI, 1995, p.186). No final dos anos 1960, além das Vilas ocorre a multiplicação de favelas, como a da Vila Fraternidade, Vila do Grilo e do Pito Aceso que indicavam o agravamento progressivo da questão da pobreza na cidade.

\section{Mapa 5}

Londrina: localização de algumas Vilas, 1958



Fonte Yamaki (2003, p.43) 
Figura 2

Vila da Fraternidade: abertura de rua - 1968

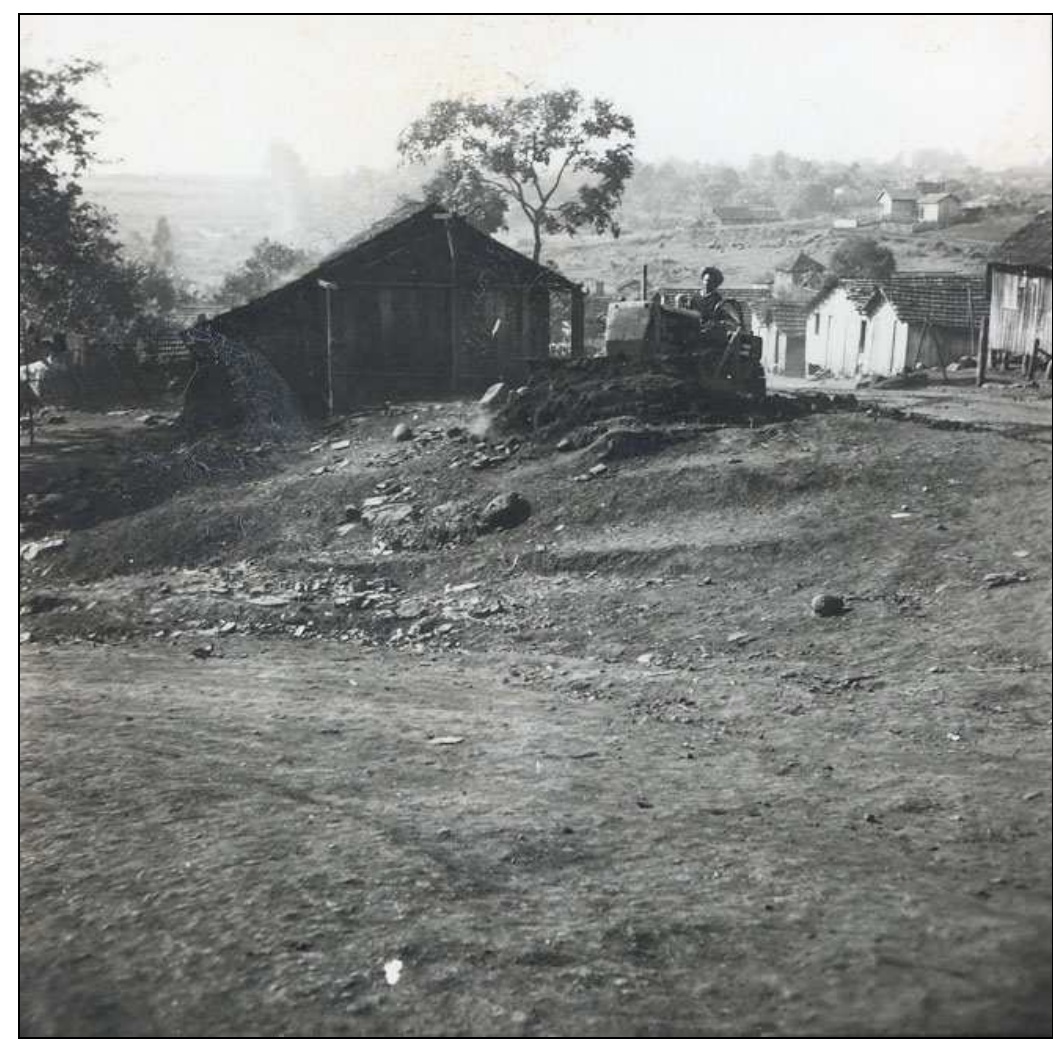

Fonte: Acervo do Museu Histórico de Londrina.

Autor Oswaldo Leite

Os embriões do circuito inferior aparecem nas formas pelas quais os moradores das Vilas e Favelas de Londrina enfrentavam o desafio de sobreviver na cidade. Os estudos sobre a Vila Casoni são mais detalhados e oferecem mais informações sobre o modo como seus moradores se inseriram na economia urbana nascente de Londrina. Em alguns depoimentos temos os seguintes relatos:

Antigamente não existia caminhão, tudo era carroça [...] Os antigos falavam: 'Vai na Vila dos carroceiros' (era a Vila Casoni e arredores) Depoimento do Sr S. R.

Eu vim para cidade, [...] eu fui trabalhar numa copa de hotel, Aí fui ajudante de cozinha, fui cozinheiro, depois garçom, depois arrumei serviço no banco. Era solteiro. Aí fui procurar outro serviço. Entrei como pintor da Viação Garcia, pintando parede. Depois fui violeiro. La no predinho da Sta Catarina inauguramos um dupla, era Louro Prata e Pingo D'água. P. 39 Depoimento do Sr. P. M

"[...] eu fui o primeiro garapeiro de Londrina. O primeiro carrinho de garapa quem teve fui eu. Eu já vendi pastel em Londrina, eu já vendi pipoca, eu já fui engraxate, já fui carregador de mala, já fui agenciador de pensão.[...] Nós ganhávamos naquela época 2 mil 
réis por cada freguês que nós conseguíamos para o hotel" Depoimento do Sr. M. P. R.

Eu acho que tinha quinze anos já costurava pra fora no corte (costura). Quando eu fui aprender no corte eu já ia pegando roupas de colegas, roupinhas de crianças.[...] Depois de casada eu continuei costurando muito. Tenho muita freguesia. Levanto muito cedo, as cinco da manhã, faço o serviço de casa depois pego a costura." Depoimento da Sra. M. R. S. (IPAC, 1987, p. 33 a 40)

As próprias Vilas passaram a oferecer algumas oportunidades para que aparecessem atividades econômicas voltadas para a população pobre. As Vilas mais próximas do centro ganharam, com certa rapidez, alguma estrutura, dando origem a pequenos núcleos comerciais, onde alguns estabelecimentos do tipo bares, empórios ou mercearias se instalaram. Formavam-se, assim, pequenos empreendimentos comerciais, movidos pelo trabalho familiar, que floresciam com o aumento da população dos bairros e sua estruturação ${ }^{46}$.

O principal jornal da cidade também registrava a expansão do comércio ambulante, atividade típica do circuito inferior, e diretamente ligada às dificuldades da população pobre.

Nossa cidade foi invadida por uma onda de mascates, entrados no país como imigrantes destinados à lavoura. O fisco permite que exerçam a atividade de mascates, já que deles recebem taxas e impostos, dando-Ihes os respectivos alvarás. O próprio fisco auxilia tais elementos a burlarem a legislação da imigração. Vieram como lavradores e agora são mascates e o fisco endossa a burla. A quem apelar? (apud ARIAS NETO, 1993, p. 163).

A estação rodoviária e seu entorno eram locais preferenciais para a atuação desses trabalhadores, ligados ao comércio ambulante. Sua presença incomodou as autoridades municipais que em meados dos anos 1950 restringiram sua atuação naquele local (ARIAS NETO, 1993).

Ao longo das décadas de 1950 e 1960 os contrastes entre a concentração da riqueza e pobreza em Londrina foram se acentuando e tornando mais complexa e contraditória a formação da economia urbana. Ao lado da paulatina formação de um dinâmico circuito superior movido

\footnotetext{
${ }^{46}$ A pavimentação da Vila Agari, local de madeireiras, por exemplo, se daria no final dos anos 1960, minimizando problemas como a poeira e o barro na época das chuvas. O primeiro posto de saúde somente em 1977 (NANTES, 2003)
} 
pela cafeicultura, foram se constituindo formas embrionárias e dispersas de enfrentamento das situações de pobreza e insegurança a que estavam submetidos aqueles que não estavam diretamente inseridos nas atividades econômicas que compunham a inserção de Londrina na divisão territorial e social do trabalho. 


\section{CAPÍTULO 2}

\section{As transformações da economia urbana de Londrina no período técnico-científico}

\section{1 - As condições para o pleno desenvolvimento dos circuitos da economia urbana}

Os anos 1970 representam o início de um novo período para a economia urbana londrinense. Ao longo da década a dinâmica econômica da cidade sintetizou as complexas transformações decorrentes do processo de difusão do meio técnico-científico-informacional incluindo a modernização da agricultura, a industrialização e a intensificação da urbanização.

Como resultado dessas transformações tanto o circuito superior como o circuito inferior passaram a se sustentar em determinações internas ao meio urbano, reduzindo progressivamente a dependência das dinâmicas do meio rural. As condições para estruturação e desenvolvimento dos circuitos da economia urbana tornaram-se plenas e maduras, na medida em que, como conseqüência dos processos elencados, a população, o trabalho e os trabalhadores tornaram-se predominantemente urbanos e $o$ meio construído e as principais atividades econômicas ganharam novos conteúdos.

Analisar a economia urbana londrinense, levando em conta as repercussões dessas modernizações requer que se considere sua imbricação com outras escalas, pois, como nos lembra Maria Laura Silveira (2004, p.61): "A dinâmica da cidade somente pode ser compreendida à luz da dinâmica do território". Com base nessa premissa analisaremos as alterações na inserção de Londrina e do Paraná na divisão territorial do trabalho que resultaram da expansão do meio técnicocientífico, da modernização da agricultura, da industrialização e urbanização em Londrina e no Norte do Paraná. 


\subsection{1 - A primeira fase de difusão do meio técnico- científico-informacional no Paraná e em Londrina}

$\mathrm{Na}$ escala do território nacional, os anos 1970 foram marcados pela primeira fase de construção e difusão do meio técnicocientífico-informacional. Descrevendo os períodos por meio dos quais se propõem a explicar a sucessão de usos do território brasileiro, Milton Santos e Maria Laura Silveira nos dizem que:

O terceiro grande período é a construção e a difusão do meio técnico-científico-informacional. Cabe, todavia, diferenciar uma primeira fase, um período técnico-científico que, no Brasil dos anos 70, caracterizou-se, entre outros aspectos, por uma revolução das telecomunicações. É sobretudo nesse momento que, ultrapassando o seu estágio de pontos e manchas, o meio técnico realmente se difunde. Mas o novo meio geográfico (técnico-científicoinformacional) permanece circunscrito a algumas áreas. (SANTOS e SILVEIRA, 2001, p.28)

Londrina e seu entorno regional são participantes importantes dessa primeira fase de difusão do meio técnico-científico a partir dos anos 1970. Representam também pontos importantes no processo de interiorização da urbanização. A construção de rodovias conectando o Sul e o Sudeste do país, assim como os aeroportos, usinas elétricas, rede telefônica com capacidade para realizar interurbanos são exemplos de eventos que aproximaram Londrina e o núcleo industrial paulista desde os anos 1950, fazendo com que o Norte do Paraná passasse a integrar a Região Concentrada (SANTOS e Silveira, 2001, p.42).

Uma das diferenças que marcam o início de um novo momento no Paraná é que, a partir dos anos 1970, se fizeram sentir as conseqüências do projeto paranaense de desenvolvimento.

O projeto paranaense, também chamado de "modelo paranaense", centrava forças no papel do Estado como promotor do desenvolvimento. Em outras palavras, enquanto em nível nacional - Estado assumiu a tarefa de conduzir a economia após 1930 e reforçou tal tarefa nas décadas subseqüentes, fazendo investimentos que criavam condições para a produção e reprodução do capital pelo caminho da industrialização; no Paraná, o estado só assumiu de maneira mais efetiva essas funções nos anos 1960 (FRESCA, 2004, p.170) 
A intenção das novas elites que haviam chegado ao poder nos anos $1960^{47}$ era industrializar o Paraná como forma de modificar sua inserção subordinada na divisão territorial do trabalho como fornecedor de gêneros agrícolas e evitar as perdas que o Estado sofria com essa condição (FRESCA, 2004, p.169). Na prática essa intenção se traduziu na criação de uma série de empresas estatais que coordenaram vultosos investimentos realizados na integração do território paranaense e na expansão de diversas redes técnicas: rodovias, produção e distribuição de energia elétrica, telefonia e saneamento básico.

Nessa perspectiva, podemos dizer que a produção do meio técnico-científico e o aumento de sua densidade técnica são formas pelas quais o Estado contribuiu diretamente para a formação e o desenvolvimento do circuito superior da economia urbana em Londrina, especialmente a implantação de indústrias modernas.

A criação de infraestrutura é uma maneira de financiar indiretamente (e às vezes diretamente, em função do nível de corrupção dos planificadores e dos funcionários) a implantação de indústrias modernas. Sem dúvida, é necessário distinguir as infraestruturas indispensáveis à modernização de um Estado daquelas que são criadas com o objetivo deliberado de atrair investimentos. Mas, nos dois casos, os resultados são mais ou menos os mesmos. (SANTOS, 1979, p.130)

O projeto paranaense de desenvolvimento, alardeado inicialmente como uma forma de fazer avançar o desenvolvimento no Estado, sofreu os constrangimentos da época, tendo que se adequar aos objetivos das políticas federais de desenvolvimento dos governos

\footnotetext{
47 “A condução de Ney Braga à chefia do Poder Executivo, em 1961, personificando o Paranismo, irá significar a revisão do papel do Poder Executivo estadual visando estabelecer um processo de mudança na forma de acumulação, de rural para industrial-urbano. [...] Com Ney Braga a intervenção estatal visa, sobretudo, criar e expandir as condições gerais de produção o que implicava na revisão da estrutura governamental e na ênfase da atividade planejadora dentro dos corpos da administração publica. Nesse sentido, os municípios paranaenses passam a contar com órgãos de promoção do desenvolvimento urbano (SANEPAR, FAMEPAR e COHAPAR) e o desenvolvimento industrial com uma poderosa instituição de financiamento: a CODEPAR (1962). O principal instrumento de ação é o Fundo de Desenvolvimento Econômico (FDE) instituído com recursos tomados de poupança interna ao Paraná na forma compulsória sobre o Imposto de Vendas e Consignação (IVC), com recursos contabilizados fora do Orçamento do Estado, o que dava à CODEPAR uma grande autonomia e flexibilidade de decisões. A aplicação de recursos do Fundo recaiu prioritariamente sobre a criação de infraestruturas para o desenvolvimento econômico, o que vale dizer, produção de energia elétrica, telecomunicações e transportes" (RAZENTE, 2003, p.43).
} 
autoritários pós-1964. Tânia M. Fresca (2004, p.172) explica as conseqüências das adequações sofridas pelo projeto de desenvolvimento paranaense.

Por essas adequações o projeto foi direcionado para o grande capital de qualquer origem, em detrimento do pequeno e médio capital local e se deslocou da substituição de importações para a tese da complementaridade (AUGUSTO, 1978, p.222) na ótica da divisão territorial do trabalho em nível nacional

O caso da energia elétrica é emblemático nas transformações que os investimentos estatais proporcionaram. A fragmentação do sistema de produção e distribuição de energia provocava freqüentes racionamentos e interrupções do serviço ${ }^{48}$. Com a criação da Companhia Paranaense de Energia Elétrica (COPEL) em 1954 e o aporte de recursos estaduais e federais provenientes das taxas de eletrificação, do Banco Nacional de Desenvolvimento Econômico (BNDE) e da Eletrobrás teve início uma fase de vultosos investimentos na construção do sistema elétrico estadual (COPEL-UFPR, 1994).

Os primeiros alvos das ações da COPEL foram os sistemas de produção de energia, com a construção de hidrelétricas e termoelétricas, e as linhas de transmissão, que foram ampliadas ou construídas $^{49}$. A ampliação da capacidade de geração ${ }^{50}$ e a racionalização e integração territorial da rede de transmissão, conectada com a de outras unidades da federação, praticamente eliminaram os racionamentos e as constantes interrupções do fornecimento de energia no Estado.

A disponibilidade de insumos como a energia elétrica mostrou-se fundamental tanto para a industrialização, como para a intensificação da urbanização no Paraná.

\footnotetext{
${ }^{48}$ Até meados dos anos 1960 o Paraná não possuía um sistema estadual integrado e era abastecido por diferentes empresas privadas e formas de produção e distribuição: empresas autoprodutoras, geradores a diesel comprados pelas prefeituras, empresas de energia elétrica com áreas de atuação restritas, a exemplo da Empresa de Energia Elétrica de Londrina pertencente a sócios da CMNP e da Cia de Força e Luz do Paraná, pertencente a um grupo financeiro norte-americano (COPEL-UFPR, 1994, p.95)

49 Além de usinas como a termelétrica de Figueira, próxima à Londrina, também foram construídas linhas de transmissão e estações de distribuição que garantiram o abastecimento regular de todo Norte do Paraná (COPEL - UFPR, 1994)

${ }^{50}$ A potência instalada sob controle da Companhia de Energia Elétrica do Paraná (COPEL) mais do que dobrou entre 1960 e 1970, passando de 147.714 kW em 1960, para 354.000 kW em 1970 (COPEL-UFPR, 1994, p.110)
} 
De fato, se existe alguma relação entre eletrificação e fomento à indústria, ela parece ser clara apenas no período seguinte quando aí, sim, em função da abundância de energia, um número considerável de empresas irá se transferir e/ou ampliar suas atividades no Paraná (COPEL - UFPR, 1994, p114)

Outra rede técnica de fundamental importância na redefinição da inserção paranaense na divisão territorial do trabalho foi a de telecomunicações. No Paraná, até meados dos anos 1960, havia um mosaico de redes, sistemas e empresas de telefonia. A criação da Companhia de Telecomunicações do Paraná (TELEPAR) em 1963 deu início a profundas transformações na rede de telecomunicações paranaense.

A partir de 1968, a TELEPAR começou a construir uma rede de centrais de telefonia para a realização de ligações interurbanas com base em novas tecnologias ${ }^{51}$. Essas centrais foram interligadas à rede nacional implantada pela Empresa Brasileira de Telecomunicações (EMBRATEL) na montagem do sistema de discagem direta à distância DDD. A construção da rede paranaense se deu progressivamente a partir de diversas rotas de interligação. As centrais da rota norte-sul foram as primeiras a serem construídas, interligando cidades como Paranaguá, Curitiba, Ponta Grossa, Londrina e Maringá, e começaram a operar em 1970 (LAUDES, [1971?], p. 94).

A situação da telefonia em Londrina é bastante particular. 0 serviço fora municipalizado em 1964 com a criação da Companhia Municipal de Telecomunicações de Londrina (SERCOMTEL) e, com isso, a telefonia se desenvolveu de forma acelerada em Londrina e municípios vizinhos. O desenvolvimento da telefonia e, como veremos a seguir, também dos sistemas de saneamento básico proporcionaram condições relativamente favoráveis para o desenvolvimento urbano de Londrina, se comparadas com outras regiões do país. Tais redes atendiam aos reclamos dos atores principais da economia urbana, mas também favoreceram uma parcela considerável da população urbana.

\footnotetext{
${ }^{51}$ Tratava-se do sistema de microondas que permitiu a formação do sistema DDD no Brasil. Curitiba, após a entrada em funcionamento das estações da EMBRATEL foi a primeira cidade do Paraná a se integrar ao novo sistema. A interiorização das centrais de microondas ficou a cargo da TELEPAR. (LAUDES, 1971)
} 
Gráfico 4

Londrina: evolução da telefonia fixa, 1960 - 1990

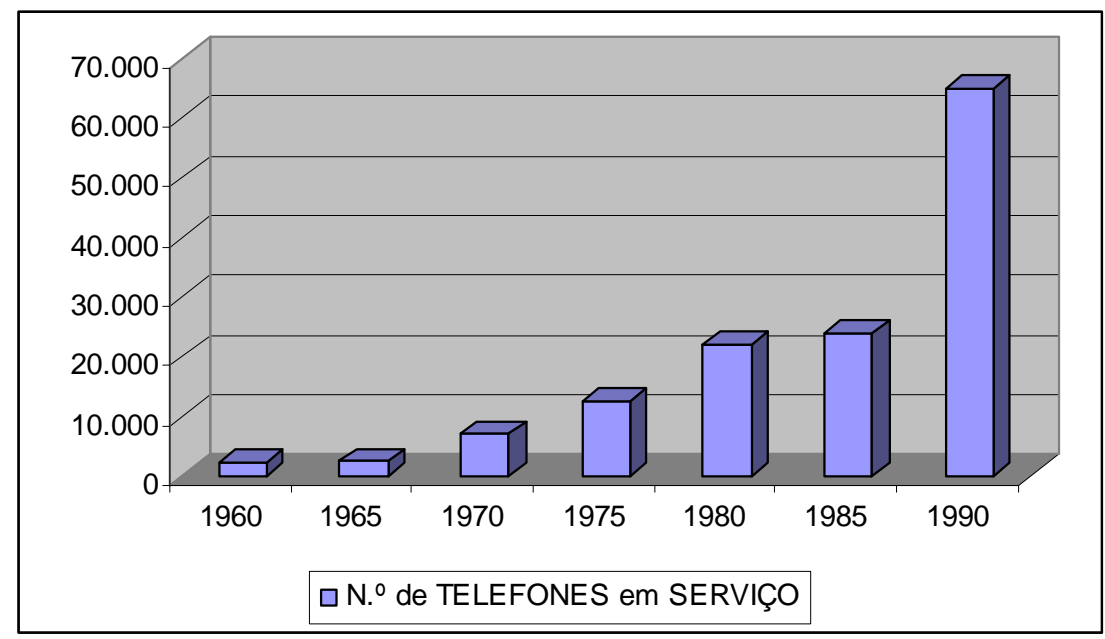

Fonte: Perfil Londrina, 1986 e 1993

Além das conexões estaduais, a central da rede de microondas, construída pela TELEPAR em 1970, permitiu que Londrina fosse a quarta cidade brasileira a integrar o sistema DDD (KROETZ, 1982, p.72). Assim como ocorrera com a energia elétrica, após a formação do sistema estadual, o serviço de telefonia fixa em Londrina apresentou expansão da oferta superior a da demanda. A regularidade dos serviços e a disponibilidade de telefonia e energia elétrica tiveram papel decisivo para as transformações da economia urbana londrinense.

No tocante ao saneamento básico, desde a década de 1930, com a promulgação do Código das Águas (Decreto n. ${ }^{2} 24.643$, de julho de 1934), os serviços privados nesse setor foram paulatinamente absorvidos pelo Estado, que passou a ter poder de fixar as tarifas. De maneira geral, os serviços de saneamento básico ficaram a cargo das prefeituras ou governos estaduais, que criaram seus departamentos de água e esgoto. No Paraná, no contexto da efetivação do "projeto paranaense", foi criada uma empresa de economia mista para cuidar do saneamento básico: a Companhia de Saneamento do Paraná (SANEPAR).

O objetivo era reduzir os déficits de atendimento em todo Estado. O grau de precariedade dos sistemas de saneamento pode ser avaliado pelo trecho a seguir, retirado da mensagem do poder executivo enviada à Assembléia Legislativa, por ocasião da criação da empresa. 
A situação do Paraná no concernente à água e esgoto é bastante precária. Apenas $8,3 \%$ da população é servida por rede de abastecimento de água, e apenas $4,1 \%$ é servida de rede de esgotos. Das 221 sedes municipais, 13 possuem ambos os serviços, e 37 somente o de água. Das 20 cidades mais populosas do Estado (segundo o censo de 1950), apenas 11 possuem serviços de água satisfatórios. (SCHUSTER, 1994, p.144)

No plano federal, a política de financiamento da infraestrutura de saneamento básico contou com recursos do Banco Nacional da Habitação (BNH) na composição do Plano Nacional de Saneamento - PLANASA ${ }^{52}$ a partir de 1971 (IPEA, 1995).

Não cabe aqui aprofundar a discussão sobre a política centralizadora do regime militar e sua conhecida leniência para com as necessidades de infraestrutura ligadas à reprodução da maioria da população. O que queremos enfatizar é a distribuição dos recursos federais alocados no Plano Nacional de Saneamento, os quais foram direcionados prioritariamente à sustentação financeira das Companhias Estaduais de Saneamento Básico (CESB), promovendo assim, a centralização administrativa no setor (IPEA, 1995, p. 105). No Paraná os recursos federais foram repassados à SANEPAR, a quem coube executar as ações previstas pelo planejamento federal (SCHUSTER, 1994).

Com essa política, a qual limitava o acesso das prefeituras aos recursos federais, muitos departamentos municipais ficaram inviabilizados, visto que os recursos gerados pelas tarifas pagas pelos usuários não eram suficientes para fazer frente às necessidades de expansão dos sistemas na velocidade imposta pela urbanização.

Em Londrina, o forte crescimento urbano impunha a necessidade de investimentos nos sistemas conexos de tratamento, adução e distribuição da água e também de coleta e tratamento de

\footnotetext{
${ }^{52}$ Durante a ditadura militar a elaboração das políticas federais que incidiram sobre temas diretamente ligados à reprodução da sociedade como um todo e, especialmente dos trabalhadores, baseou-se em formas de financiamento com recursos obtidos do Fundo de Garantia por Tempo de Serviço (FGTS). O FGTS, principal fonte dos recursos do antigo Sistema Financeiro da Habitação (SFH) é uma forma de poupança forçada retirada compulsoriamente dos salários e, em menor proporção e de forma mais branda, também dos empresários. Vale ressaltar, portanto, que particularmente, o financiamento da expansão da habitação e do saneamento básico ao longo dos anos 1970 e início dos anos 1980 se fez à custa do fundo público construído com a poupança forçada imposta aos trabalhadores. (IPEA, 1995)
} 
esgoto. Essa necessidade levou o município a assinar contrato de concessão desses serviços com a SANEPAR em 1973.

Com a adesão ao Plano Nacional de Saneamento a SANEPAR obteve acesso a linhas de financiamento que sustentaram a expansão da empresa até o início dos anos 1980 (SCHUSTER, 1994, p.156). A SANEPAR que, em 1972, atendia apenas 16 municípios, passou a atuar em 264 municípios em 1985, incluindo Londrina. Com essa expansão cresceu também o aporte de recursos financeiros provenientes das tarifas pagas pelos usuários.

O problema do abastecimento de água em Londrina foi relativamente solucionado pela SANEPAR a partir de 1977 com a construção do "Sistema Tibagi" 53 . Atualmente, segundo a Prefeitura de Londrina $^{54}, 98 \%$ da população do município têm acesso ao abastecimento de água por rede geral e $75 \%$ conta com ligações ao sistema de esgoto. Assim como no caso da energia elétrica, as redes de saneamento básico atuais foram implantadas pelo Estado e foram fundamentais para a estruturação das cidades e a vida cotidiana que elas suportam.

O setor de transportes também foi alvo da atuação do poder público no contexto do projeto paranaense. Nesse caso, o objetivo era promover a integração territorial do Paraná e melhorar as condições de circulação em todo o Estado. Os investimentos possibilitaram a melhoria das principais rodovias do Norte do Paraná: a BR 369, que liga a região a São Paulo, e a BR 376, que vai de Apucarana a Ponta Grossa. Essas rodovias estavam totalmente concluídas e asfaltadas no início dos anos 1970 (FRESCA, 2004, p. 173).

A partir de então Londrina e seu entorno regional passaram a ter melhores possibilidades de ligação não apenas com Ponta Grossa e Curitiba, por meio da "Rodovia do Café" (BR - 376), mas também com Cascavel, no sudoeste do Paraná e outras regiões do Estado. A circulação

\footnotetext{
${ }^{53}$ O Sistema Tibagi é formado pelo conjunto de estações de tratamento, redes de adução e distribuição de água que capta água para o abastecimento de Londrina no Rio Tibagi que atravessa parte do munípio de Londrina. ${ }_{54}$ Para essas informações utilizamos a publicação da Prefeitura de Londrina denominada "Perfil Londrina, 2007".
} 
interna e a integração territorial paranaenses melhoraram substancialmente.

A disponibilidade de energia elétrica, serviços de telecomunicações, saneamento básico e de rede rodoviária contribuíram para o desenvolvimento de novas especializações produtivas que alteraram a inserção do Estado e da cidade na divisão territorial do trabalho. A nova inserção se configurou por meio da formação de agroindústrias e da expansão das lavouras mecanizadas de soja e trigo. As novas especializações do trabalho na escala regional visavam o fornecimento de matérias primas para indústria química (óleos vegetais brutos), de produtos alimentares (óleos vegetais refinados e trigo para os moinhos) e o consumo produtivo de insumos industriais, máquinas e equipamentos agrícolas. 


\subsection{2 - As novas especializações produtivas: a expansão das lavouras temporárias mecanizadas}

Segundo Cláudio R. Bragueto (1996) a nova inserção da microrregião homogênea de Londrina na divisão territorial do trabalho, promovida pela modernização da agricultura, se realiza a partir de dois movimentos distintos e conexos, ocorridos a partir dos anos 1960.

O primeiro desses movimentos é a reestruturação da cafeicultura paranaense, por meio da introdução de novas exigências técnicas e de produtividade, como, por exemplo, o adensamento dos cafezais, o plantio em curvas de nível e o uso de insumos industriais. Por conta dessas exigências técnicas, feitas pelos órgãos de fomento ${ }^{55}$, houve fortes impactos nas bases sobre as quais se estabeleciam as relações de produção na cafeicultura, afetando especialmente a manutenção das culturas intercalares constituídas por lavouras temporárias como: arroz, feijão e milho. O segundo movimento é a expansão de novas lavouras temporárias, como a soja e o trigo, ao longo dos anos 1970.

\section{Gráfico 5}

Microrregião Homogênea de Londrina: evolução da área colhida das lavouras temporárias, 1970 a $1980(\%)$.

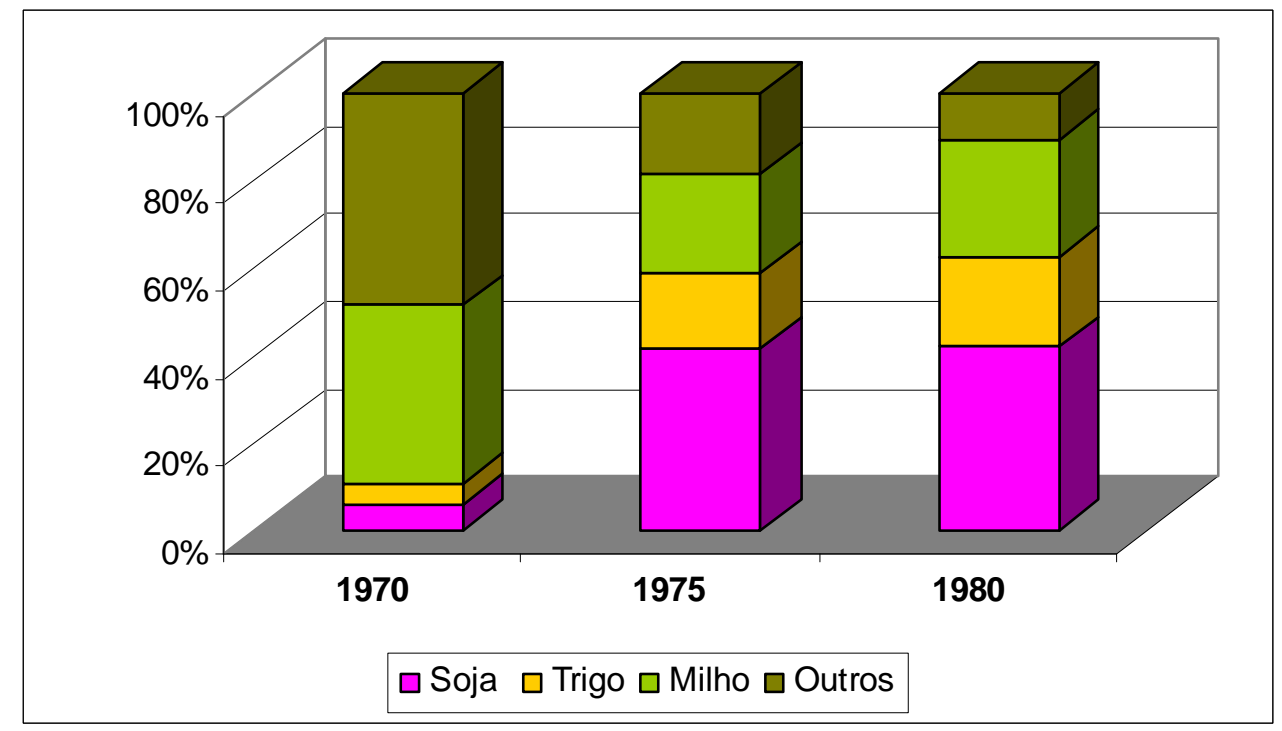

Fonte: Bragueto (1996, p.185)

\footnotetext{
55 Bragueto (1996, p.183) explica que com a criação do Sistema Nacional de Crédito Rural em 1965 essas exigências passaram a condicionar o acesso aos financiamentos.
} 
A expansão da soja, que paulatinamente, substituiria ${ }^{56}$ os cafezais e assumiria a condição de nova especialização produtiva regional ao lado das agroindústrias, se fez em consonância com a difusão de uma nova base técnica para a produção rural.

Entre 1970 e 1975 ocorreu um aumento de 47\% no número de estabelecimentos que utilizam adubos químicos na região de Londrina. $\mathrm{O}$ uso de defensivos também cresceu significativamente e atingiu em 1985 a $79 \%$ dos estabelecimentos.

Em 1970 ainda era grande número de produtores que utilizavam em seu estabelecimento apenas força humana. Apenas $51 \%$ utilizava força animal ou mecânica em seus estabelecimentos, sendo que havia predomínio da força animal, pois somente $14 \%$ declararam utilizar força mecânica. A partir da década de 80 a situação se inverte. Em 1985, mais de $76 \%$ dos estabelecimentos utilizavam algum tipo de força nos trabalhos agrários que não a humana, e em especial ocorre o predomínio da força mecânica em $64 \%$ dos estabelecimentos. Ou seja, sem dúvida a Microrregião Geográfica de Londrina é uma das regiões do Brasil onde o processo de generalização da tecnificação do campo se deu de forma mais intensa e a rapidez, intensidade e tipo de tecnologia implementada, via política agrícola, foi a principal responsável pelas profundas transformações na estrutura fundiária e nas relações de trabalho ocorridas na região a partir de 1970 (BRAGUETO, 1996, p. 229).

Essas reestruturações trouxeram o aumento da área média dos estabelecimentos, a redução do número de parceiros e colonos e o aumento do número de assalariados (bóias frias) e intensificaram as migrações rural-urbanas ${ }^{57}$. Também houve mudanças no perfil dos produtores rurais.

No período 1970-80, formou-se no Paraná, e isso vale também para a microrregião de Londrina, uma camada de médios produtores tecnificados formada em sua maioria de proprietários fundiários (BRAGUETO, 1996, p.231).

Essa última mudança tem interesse especial para a discussão sobre a economia urbana, por sua ligação com novos tipos de consumo produtivo e com a formação de agroindústrias na região. Isso porque, com o advento das agroindústrias, foram alterados os papéis

\footnotetext{
56 “Ou seja, há fundamentalmente a substituição das lavouras permanentes pelas lavouras temporárias, lavouras estas que foram altamente incentivadas via crédito e quase que totalmente mecanizáveis em todas as etapas do processo produtivo, assim como pela ampliação das pastagens plantadas, de maior produtividade, em detrimento das pastagens naturais" (BRAGUETO, 1996, p. 221).

57 Ao longo dos anos 1970, em todo Paraná, mais de 1 milhão de pessoas deixaram a zona rural. O Norte do Paraná contribuiu com nada menos que 90\% desse contingente. (IPARDES, 1983, p.12)
} 
urbanos e, com eles, também a forma da divisão local de trabalho em relação ao período da cafeicultura.

Os produtores que passaram a operar sobre a nova base técnica promoveram a ampliação da escala de produção e o aumento da produtividade do trabalho nas propriedades rurais. Nessas novas condições os esquemas de comercialização próprios a cafeicultura se tornaram inadequados. As cadeias de comercialização se estreitaram eliminando vários elos, levando ao desaparecimento gradativo dos diversos agentes envolvidos no processo. Isso afetou as pequenas cidades que abrigavam maquinistas, corretores de café, caminhoneiros que reuniam diversos lotes de café dos pequenos produtores e os transportavam para as cidades e que também transportavam esses produtos das cidades menores paras as maiores ${ }^{58}$. As indústrias processadoras e as cooperativas passaram a desempenhar esses papéis no caso da soja e do trigo, comprando a produção e se encarregando do transporte.

Os personagens da trama que se desenvolve com a nova especialização produtiva, ou seja, a produção de soja, trigo e o crescimento das agroindústrias e cooperativas, são, portanto, cada vez mais urbanos. Dentre os novos personagens urbanos destacamos a massa de migrantes rurais que acorreu para cidades como Londrina ou Maringá, intensificando nelas as atividades do circuito inferior. Destacamos também as agroindústrias processadoras de soja, trigo e outros cereais produzidos no Norte do Paraná e também as cooperativas de produtores rurais, personagens que apontavam para uma nova configuração do circuito superior da economia urbana.

\footnotetext{
${ }^{58} \mathrm{Um}$ aspecto desses efeitos pode ser apreciado pela redistribuição da população na região entre 1970 e 1991 , representada no "Mapa 7. áreas com ganhos e perdas de população", neste mesmo capítulo.
} 


\subsection{3 - As novas especializações produtivas: agroindústrias e cooperativas}

Uma das principais alterações na inserção do Paraná e, particularmente de Londrina, na divisão territorial do trabalho no período técnico-científico foi a industrialização viabilizada pelas infraestruturas produzidas, ampliadas e reorganizadas pela ação do Estado, além de outros incentivos. Conforme já apontamos, houve discrepâncias entre os objetivos e as pretensões anunciadas pelos planejadores e a configuração concreta da industrialização no Paraná, no âmbito do projeto paranaense de desenvolvimento.

Embora em nível estadual a dimensão política do projeto fosse
alterar o seu papel de agrícola para industrial, o que se assistiu foi
o encaminhamento de maior integração à economia brasileira, não
pela industrialização, como fora pensada, mas por uma
agroindustrialização extremamente articulada às demandas do país
e do mercado internacional. Foram processos principiados nos
anos 1960 , efetivados nos anos 1970 , quando a modernização da
agropecuária foi concretizada no Paraná (FRESCA, 2004, p.173).

A industrialização do Paraná, que fora pensada inicialmente como substituição das importações de produtos industriais de São Paulo, transformou-se em uma economia complementar de tipo industrial, com forte acento na modernização da agricultura e em sua integração vertical com a agroindústria. Essa mudança de rota pode ser explicada tanto pela interferência do regime militar quanto pela conivência das elites locais. (AUGUSTO, 1978; RAZENTE, 2003)

No Brasil, a partir de 1967, instaura-se de forma mais evidente a estratégia de diversificação das exportações, as quais passam a incluir, de forma crescente, produtos manufaturados, redefinindo assim a inserção do país na divisão internacional do trabalho. Essa nova inserção atendia os interesses do Estado autoritário pós-1964, sobretudo em relação à aceleração do processo de industrialização e ao enfrentamento de seus pontos de estrangulamento. Propiciava também a contínua abertura de oportunidades de investimento para o capital estrangeiro, que 
reduziu sua capacidade ociosa ao participar da exportação de manufaturados (FURTADO, 1972, p.39).

A política de diversificação das exportações possibilitou o incremento da agroindústria ${ }^{59}$ e a expansão das lavouras mecanizadas de soja e trigo no Norte do Paraná, fragmentando a região ${ }^{60}$ por meio da constituição dessas novas especializações produtivas.

A presença de matérias primas como a soja e o leite ligados à expansão de pastagens e de lavouras temporárias que substituirão o café em determinadas áreas do Norte do Paraná possibilitaram a implantação de uma série de agroindústrias. Essas empresas, as quais, em geral, eram de grande porte, concentraram-se no chamado "eixo Londrina-Maringá" que nada mais é do que o conjunto de municípios situado ao longo das vias de penetração principais (ferrovia e rodovia) projetadas pela Companhia de Terras. As empresas processadoras, sobretudo as que lidavam com esmagamento da soja e derivados do leite, localizaram-se preferencialmente nas cidades médias do interior do Estado de maneira a combinar as vantagens de localização oferecidas por essas cidades com a proximidade com áreas fornecedoras de matérias primas.

Tabela 1

Principais Agroindústrias no entorno regional de Londrina, 2007.

\begin{tabular}{|l|c|}
\hline \multicolumn{1}{|c|}{ AGROINDÚSTRIAS } & LOCALIZAÇÃO \\
\hline Braswey S/A Indústria e Comércio. & Cambé \\
\hline Comércio e Indústrias Brasileiras Coinbra S/A. & Londrina \\
\hline Cooperativa Central Agro-Industrial Ltda. & Londrina \\
\hline Big Frango Indústria e Comércio de Alimentos Ltda. & Rolândia \\
\hline
\end{tabular}

Fonte: TABELA..., 2007

\footnotetext{
${ }^{59}$ As agroindústrias são aquelas que processam a matéria prima de origem agropecuária e florestal e também as que fornecem máquinas, equipamentos e insumos utilizados nas atividades rurais. Em Londrina nos anos 1970 havia uma série de agroindústrias tais como: Fábrica de óleos da CAC; unidade de esmagamento de grãos da Anderson Clayton; Braswey; Ultrafértil, Adubos Copas; Fertiplan; Cia Cacique; Café Marrisol, entre outras (NAKAGAWARA, 1972)

${ }^{60}$ A cafeicultura havia conferido certa homogeneidade à região. A soja e o trigo se desenvolveram nas áreas em que as condições ecológicas, tais como solo e relevo compatível com mecanização, permitam alta produtividade. Assim áreas de solos arenosos ou de relevo acidentado foram dominadas pela pecuária e por outros cultivos.
} 
Conforme indicamos no início do capítulo, no período técnico-científico, as principais transformações na economia urbana de Londrina estiveram relacionadas à industrialização e à modernização da agricultura. Em conseqüência desses processos as agroindústrias e cooperativas de produtores rurais representam uma parte dos novos conteúdos do circuito superior londrinense, evidenciando a sintonia desse circuito com a divisão territorial do trabalho em suas diversas escalas.

Vale lembrar que, segundo Milton Santos (1979) o circuito superior se define como um conjunto de atividades econômicas diversas que são intensivas em capital, isto é, atividades em que o capital é o elemento preponderante e determinante e que, além disso, possuem: organização burocrática, acesso a crédito e à propaganda, grande volume de negócios e, na maioria dos casos, íntima relação com o comércio exterior. Essas características se aplicam as agroindústrias e cooperativas de produtores rurais que se desenvolveram no Paraná nesse período. Tais empresas contaram com forte apoio financeiro e técnico dos governos militares $^{61}$.

Para redefinir e racionalizar a ação das cooperativas, evitando seu enfraquecimento por meio da concorrência, o governo federal criou normas ${ }^{62}$ para definir suas formas de organização e funcionamento, adequando-as às necessidades inerentes ao processo de modernização da agricultura. Essa forma de organização estabeleceu o controle social e político sobre o movimento cooperativista no Brasil, à semelhança de outras experiências na América Latina, e estabeleceu um padrão empresarial de gestão das cooperativas, visando: a sua rentabilidade, à profissionalização de seus gestores e à viabilização de

\footnotetext{
${ }^{61}$ Nos anos 1960 havia diversas cooperativas de produtores de café, que no Norte do Paraná eram geralmente comandadas por grandes produtores e lhes serviam de apoio para realizar exportações sem utilizar a infraestrutura do IBC ou das empresas estrangeiras (CARVALHO, 1991). A maioria dessas cooperativas não resistiu a reforma bancária de 1965 e as posteriores mudanças de moeda.

62 O principal instrumento normativo desse período foi a Lei n. ${ }^{\circ} 5.764$, de 16 de dezembro de 1971, que exigia um número mínimo de 20 sócios para a constituição de uma cooperativa e sua filiação a uma entidade estadual, a Organização Estadual de Cooperativas (OCE) e outra federal, a Organização das Cooperativas Brasileiras (OCB).
} 
todo projeto de modernização da agricultura paranaense (PAULINO, 2003, p.165). Dessa maneira, surgiu a Organização das Cooperativas do Paraná (OCEPAR), que passou a atuar como fomentadora da relação entre cooperativas e produtores direcionando essas relações no sentido da montagem de complexos agroindustriais, especialmente os complexos relacionados à soja e ao trigo.

As cooperativas agropecuárias passaram a atuar como empresas orientadas pelos imperativos do mercado distanciando-se dos princípios da ajuda mútua e gestão compartilhada. Sua principal vantagem em termos de mercado é permitir aos cooperados, sobretudo aos produtores rurais mais capitalizados e organizados em padrões empresariais, uma redução do número de intermediários tanto em relação ao seu consumo produtivo, quanto ao que se refere ao armazenamento e comercialização da produção.

A força dessas organizações se multiplicou nos anos 1970 por conta de sua atuação como intermediárias na concessão dos créditos distribuídos pelo Sistema Nacional de Crédito Rural (SNCR) à agricultura voltada à exportação ${ }^{63}$. No Norte do Paraná, a presença de pequenos e médios produtores de aves, leite, milho e principalmente de soja e trigo se mostrou "solo fértil" para constituição de grandes cooperativas agropecuárias $^{64}$. Essas empresas tornaram-se responsáveis por receber, armazenar, transportar e vender a produção dos cooperados, além de viabilizar a compra dos insumos.

\footnotetext{
${ }^{63}$ Segundo Pereira e Lugnani (1991) o volume de crédito destinado às atividades agrícolas do Paraná, abarcou $20 \%$ do total nacional. Analisando o período de 1973 a 1985 os autores demonstraram que o montante de crédito concedido girou em torno de $70 \%$ do valor da produção agrícola do Paraná e em alguns anos o valor do crédito ultrapassou os $70 \%$, chegando a ser igual (100\%) ao valor da produção. Concentrou-se o maior volume de crédito em produtos ligados à balança comercial: soja e trigo, e que sustentavam a demanda de insumos industriais e máquinas, intensificando os conteúdos de ciência e tecnologia no meio rural como é próprio do processo de modernização.

${ }^{64}$ Segundo Souza et.alli (2007) o Paraná possui hoje: 1 Confederação, 7 Centrais Agropecuárias, 2 Federações, 1 Central de Crédito Rural e 203 cooperativas. Quatro ramos de atividades dominam o setor. Em primeiro lugar está a Cooperativa Agropecuária, com 60 cooperativas e 92.796 associados; em segundo, a Cooperativa de Crédito Rural, com 30 cooperativas e 50.707 associados. As cooperativas respondem em média por $50 \%$ do Valor Bruto da Produção Agropecuária (VBP) no estado e 15\% do PIB estadual e reúnem mais de 90 mil cooperados a maioria proprietários de até 50 há de terra.
} 
A partir de meados dos anos 1980, e principalmente nos anos $1990^{65}$, algumas cooperativas se transformaram em grandes agroindústrias produtoras de óleo de soja, farelo, rações, sucos industrializados e derivados do leite.

\footnotetext{
${ }^{65}$ Segundo Lugnani e Marandola (2001) em 1998 cerca de 40 cooperativas paranaenses obtiveram recursos do Programa de Revitalização de Cooperativas de produção Agropecuária - RECOOP, que disponibilizou créditos para custear a modernização dos parques industriais das cooperativas.
} 


\subsection{4 - A intensificação do processo de urbanização}

Conforme nos mostra o gráfico a seguir, em Londrina, a partir de 1970, o processo de urbanização se acelera.

\section{Gráfico 6}

Londrina: evolução das populações urbana e rural, 1960 a 2000 (n.0 de pessoas)

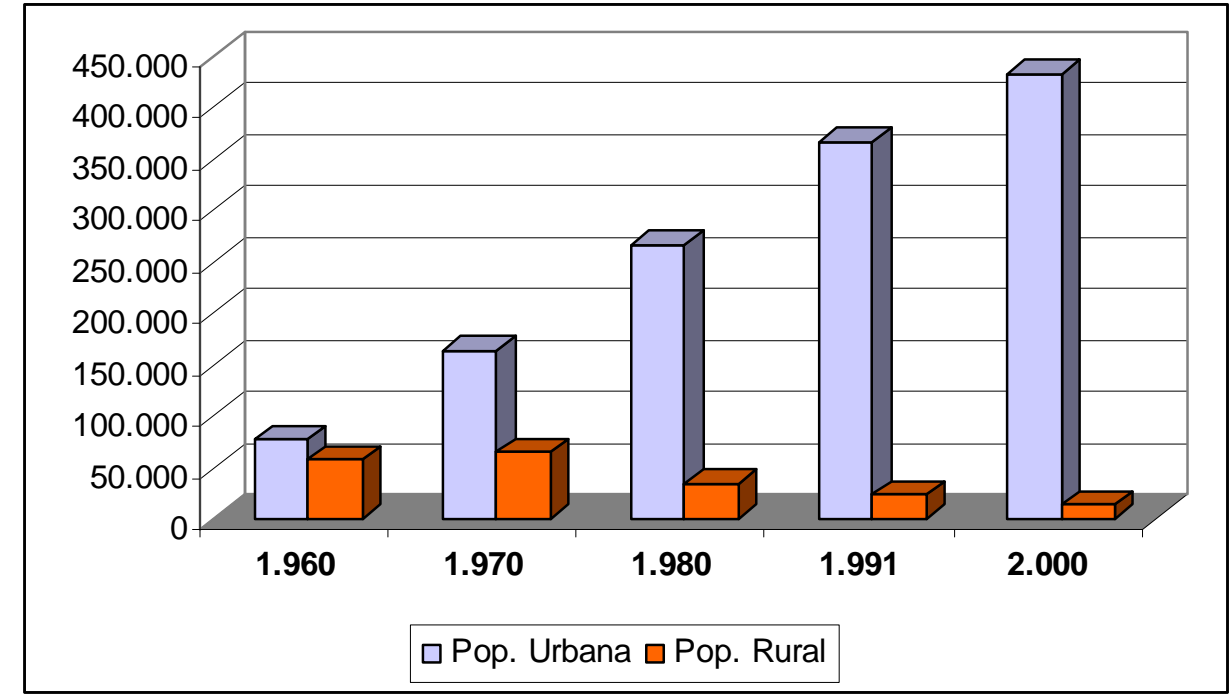

Fonte: IBGE, Censos Demográficos.

O processo de substituição da cafeicultura por lavouras temporárias mecanizadas reduziu a proporção de mão de obra rural em toda a região. A combinação entre novas formas de cultivar o café, o aumento do uso de insumos industriais e a redução da prática das culturas intercalares afetaram as relações de produção na cafeicultura. Em virtude da desestruturação das relações de produção na cafeicultura, da redução da área plantada com café e da expansão das lavouras temporárias mecanizadas, formou-se uma numerosa população excedente que, desalojada dos sítios e fazendas, migrou para os centros urbanos e para outras áreas de fronteira agrícola.

Parte do contingente de trabalhadores expulsos do meio rural pelo processo de modernização dirigiu-se às cidades onde havia maior concentração das forças produtivas no contexto do Norte do Paraná. 
de uma parcela da força de trabalho recém-imigrada. São as indústrias de transformação, principalmente de produtos agrícolas, a construção civil, o comércio diversificado, os bancos, o setor publico em geral, escolas e serviços de saúde que se constituíram em fontes de trabalho para esses migrantes (ALVES, 1991, p.63).

A concentração do capital de fato precedeu a concentração da população66. As cidades próximas a Londrina, guardadas as devidas proporções, passaram por um processo semelhante; também tiveram sua população urbana aumentada. Por outro lado, no mesmo período, grande parte dos municípios do Norte do Paraná apresentou baixo crescimento demográfico ou até mesmo perdas de população, principalmente no meio rural.

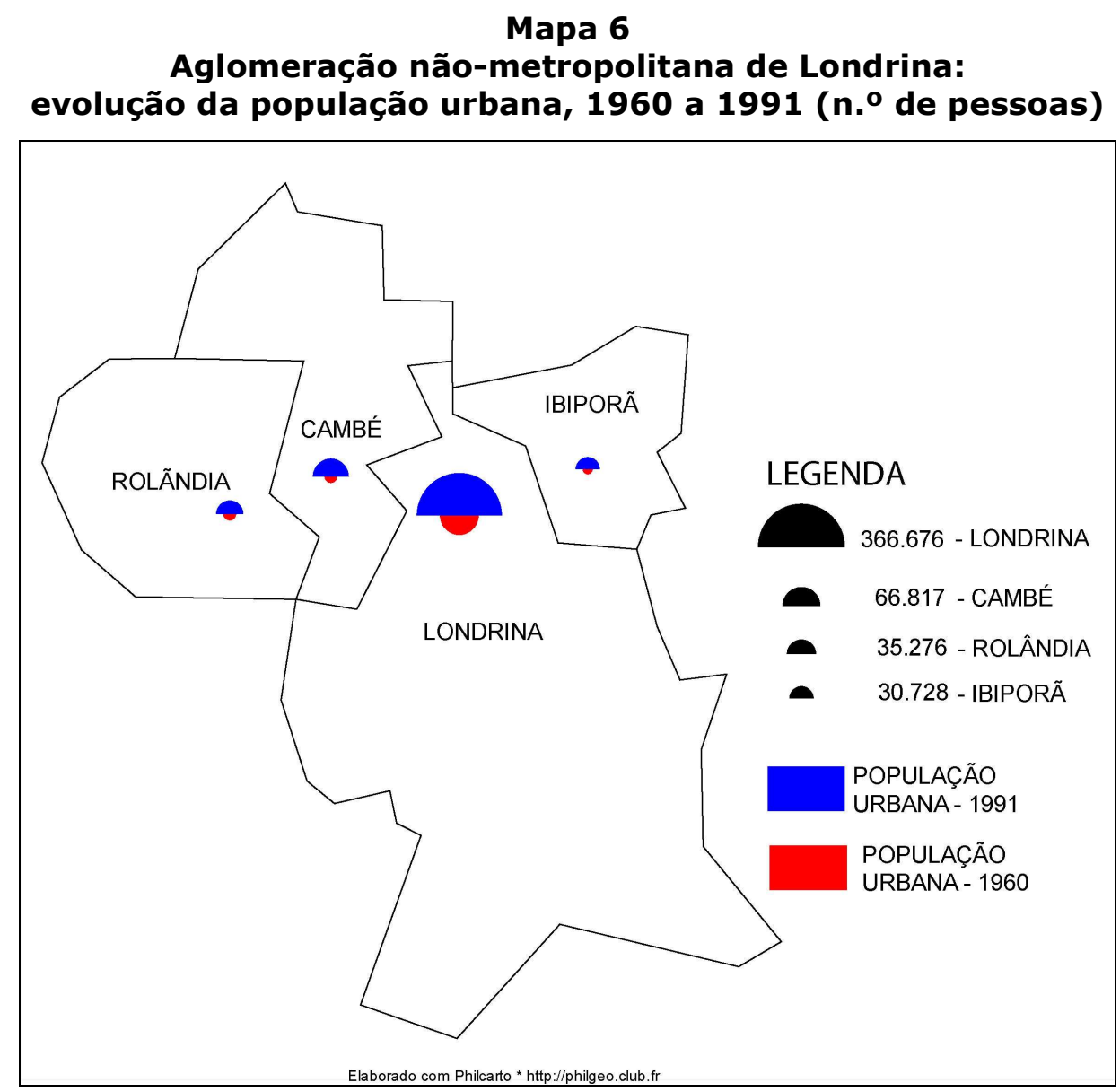

Fonte: IBGE, Censos Demográficos

\footnotetext{
${ }^{66}$ Para Jean Paul Gaudemar (1977) a mobilidade do trabalho designa uma disponibilidade crescente que faz parte de um processo abrangente no qual os homens se tornam mais e mais disponíveis para utilização compulsória de sua força de trabalho nos moldes capitalistas e o deslocamento espacial é uma face desse processo.
} 


\section{Mapa 7 \\ Norte do Paraná: áreas com ganhos e perdas de população, 1970 a 1991} (n. ${ }^{\circ}$ de pessoas)

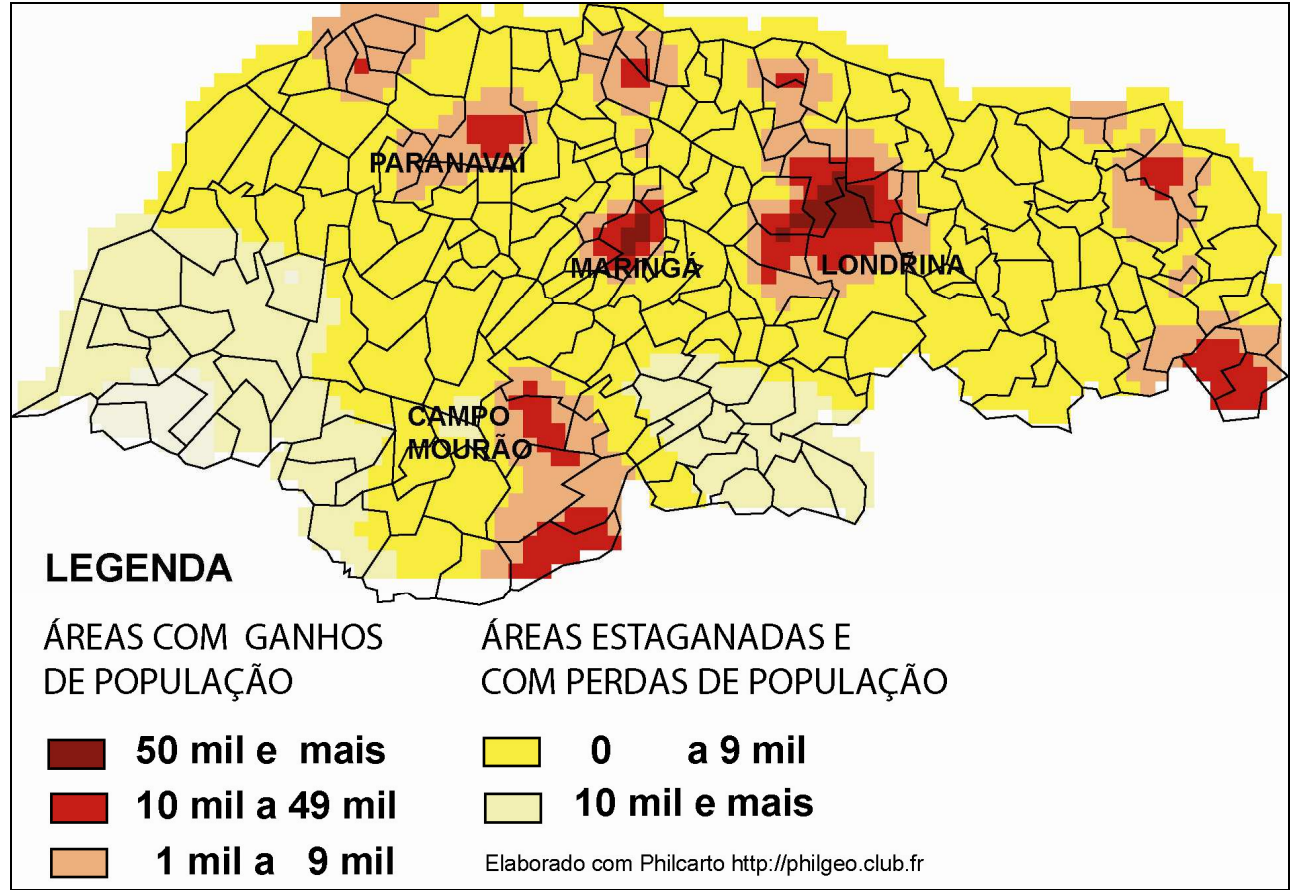

Fonte: IBGE, Censos Demográficos

Como nos mostra o Mapa 7, cidades médias do Norte do

Paraná como Londrina e Maringá tiveram os maiores ganhos de população no período. Centenas de pequenos municípios perderam população ou ficaram estagnados ${ }^{67}$.

Com a redistribuição da população forma-se uma nova configuração regional na qual a polarização exercida por Londrina e Maringá é reforçada com o crescimento demográfico acelerado. A urbanização não apenas se intensificou, mas também se concentrou nas cidades médias, que ampliaram o seu porte, diferenciando-se mais profundamente dos outros municípios da região.

O aumento da população urbana foi acompanhado pela predominância do trabalho em atividades urbanas e da contínua redução da mão de obra empregada no campo.

\footnotetext{
67 "Os pequenos núcleos urbanos cujas atividades, especialmente as comerciais, visavam atender a numerosa população rural presente no espaço regional antes da modernização da agricultura, tiveram um declínio econômico e populacional desde então. Por outro lado, núcleos urbanos considerados centros ou capitais regionais passaram a concentrar novas atividades e a receber parte da população vinda daqueles pequenos núcleos urbanos.” (ENDLICH, 1999, p.901)
} 
Gráfico 7

Londrina: evolução da PEA por setores de atividade, 1960 a 2000 (\%).

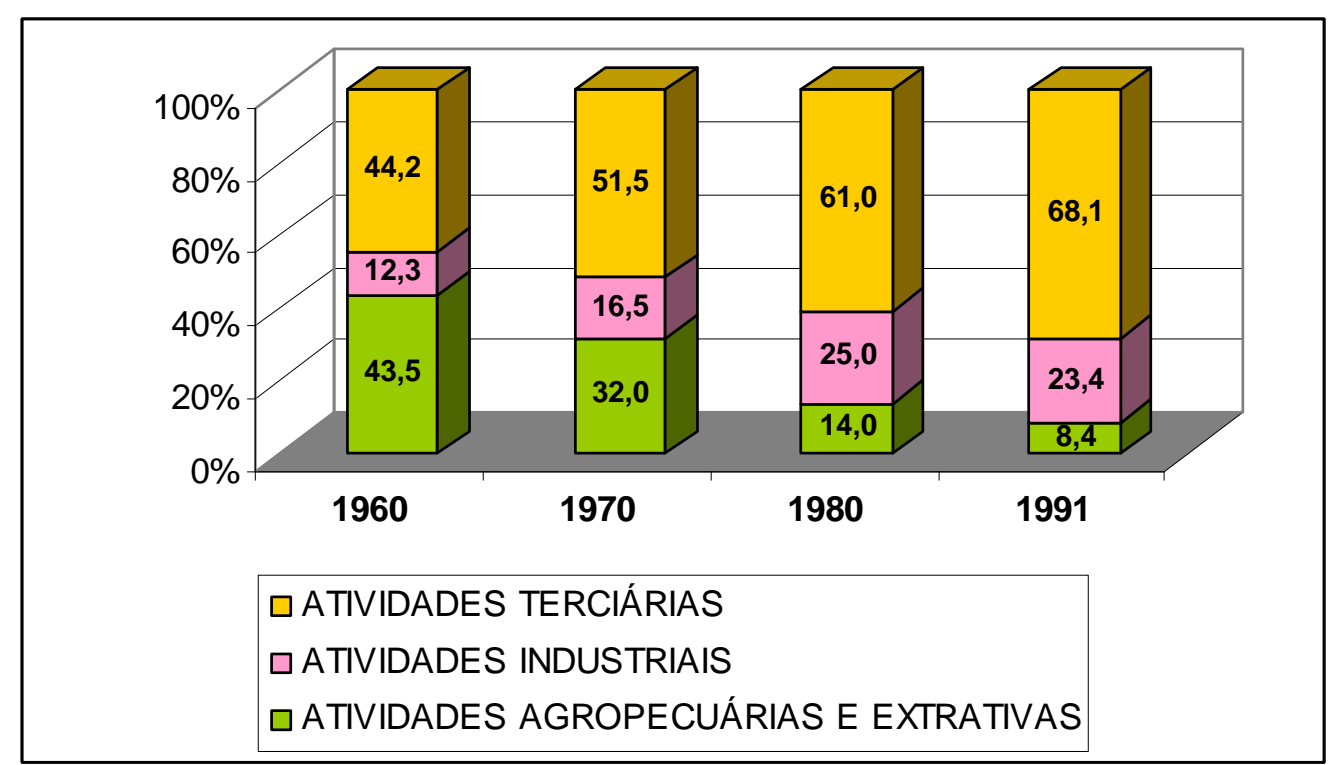

Fonte: IBGE, Censos Demográficos.

Comparando os valores no período entre 1960 e 1980 observa-se que o percentual de trabalhadores na agropecuária em 1980 se reduziu a um terço do valor de 1960 , enquanto o percentual da PEA nas atividades industriais ${ }^{68}$ dobrou no mesmo período. Esse período corresponde ao momento de maior expansão das lavouras temporárias mecanizadas. As atividades terciárias que absorviam em 1960 praticamente o mesmo percentual de trabalhadores que a agropecuária passaram a representar mais da metade dos trabalhadores do município em 1980. As tendências de aumento do percentual de trabalhadores em atividades terciárias e de redução dos trabalhadores em atividades extrativas e agropecuárias se mantiveram entre 1980 e 1991. A diferença ficou por conta das atividades industriais mais duramente afetadas pelas crises dos anos 1980, a chamada "década perdida".

\footnotetext{
${ }^{68}$ Devido às diferenças na metodologia dos Censos Demográficos de 1960, 1970, 1980 e 1991 fizemos os seguintes ajustes:

- No conjunto "ATIVIDADES TERCIÁRIAS" estão incluídas as seguintes atividades: o comércio de mercadorias, prestação de serviços, transporte e comunicações, atividades sociais, administração pública e outras atividades.

- No conjunto "ATIVIDADES INDUSTRIAIS" estão incluídas as seguintes atividades: indústria de transformação, construção civil e serviços industriais de utilidade pública ou outras atividades industriais conforme a denominação de cada Censo.
} 
Esses dados revelam que uma das bases para o pleno desenvolvimento dos circuitos da economia urbana se consolidou: o trabalho e os trabalhadores em Londrina tornam-se predominantemente urbanos.

O crescimento relativo da população economicamente ativa ligada às atividades urbanas, isto é, o aumento percentual do número de pessoas trabalhando em atividades urbanas, se manteve sempre superior ao crescimento relativo (aumento percentual) da população urbana no município, em todo o período entre 1970 e 2000. A década de 1970 se destaca como momento em que a PEA urbana teve seu maior crescimento, quase que dobrando de tamanho em relação aos valores de 1970.

\section{Gráfico 8}

Londrina: crescimento relativo da população urbana e da PEA em atividades urbanas, 1970 a $2000(\%)$.

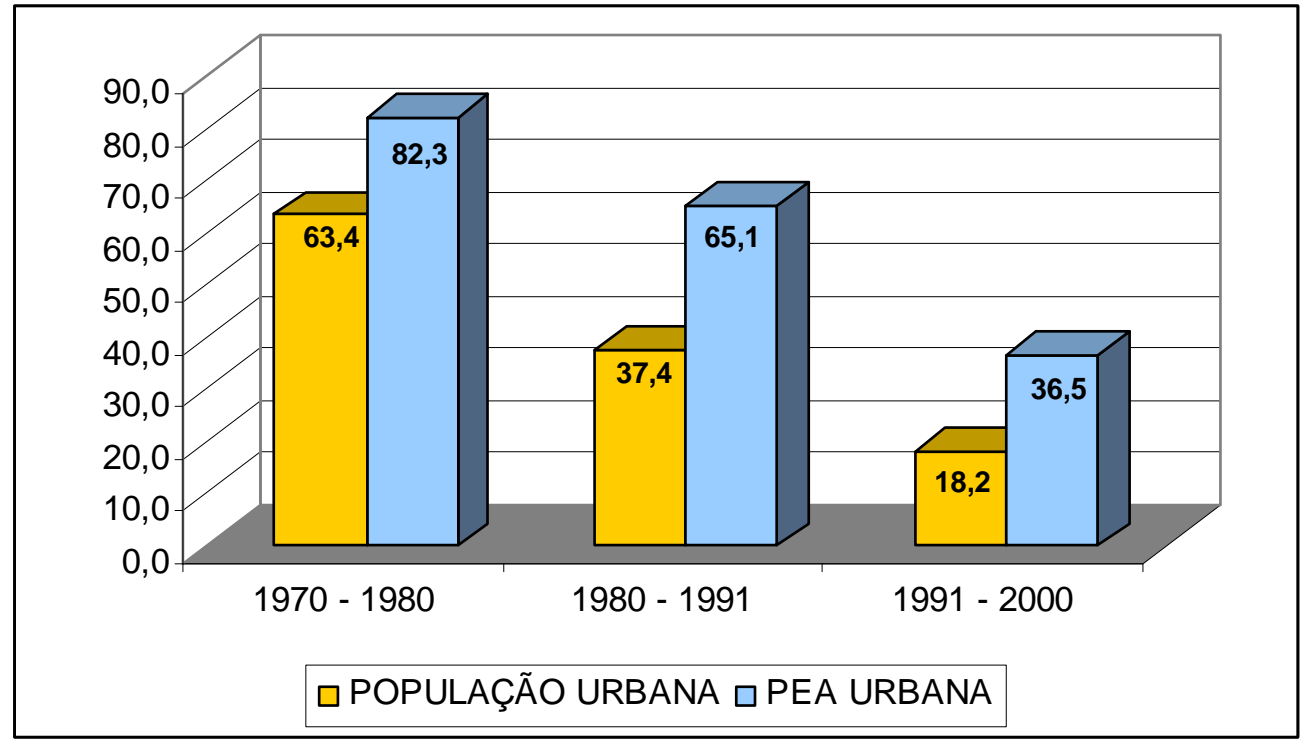

Fonte: IBGE, Censos Demográficos.

A velocidade de expansão das ocupações urbanas reflete tanto o grande crescimento da população urbana, quanto a nova inserção de Londrina na divisão territorial do trabalho, que desmantelou a divisão local de trabalho constituída no período da cafeicultura. A cidade passa a ser o lócus de uma produção industrial diversificada e, simultaneamente, assume funções de intermediação mais amplas, em relação ao período da cafeicultura, como nó espacial do consumo produtivo rural e do consumo 
final da população urbana da própria cidade e municípios vizinhos. Londrina reafirmou, assim, sua condição de cidade média no contexto da Região Concentrada.

É preciso termos em conta não apenas o caráter relativo desse crescimento, mas também os números absolutos, pois estes envolvem dezenas de milhares de pessoas e trazem a efetiva ampliação das necessidades próprias ao modo de vida urbano. Ao longo de um período de trinta anos, entre 1970 e 2000, a PEA urbana de Londrina se multiplicou por 4, passando de 54 mil para 224 mil pessoas. Segundo Baudrillard (2007, p.65) "Assim como a concentração industrial origina o aumento constante de bens, também a concentração urbana suscita a eclosão ilimitada das necessidades". Além de seu crescimento quantitativo a população urbana se diferenciou em termos de estratos de renda.

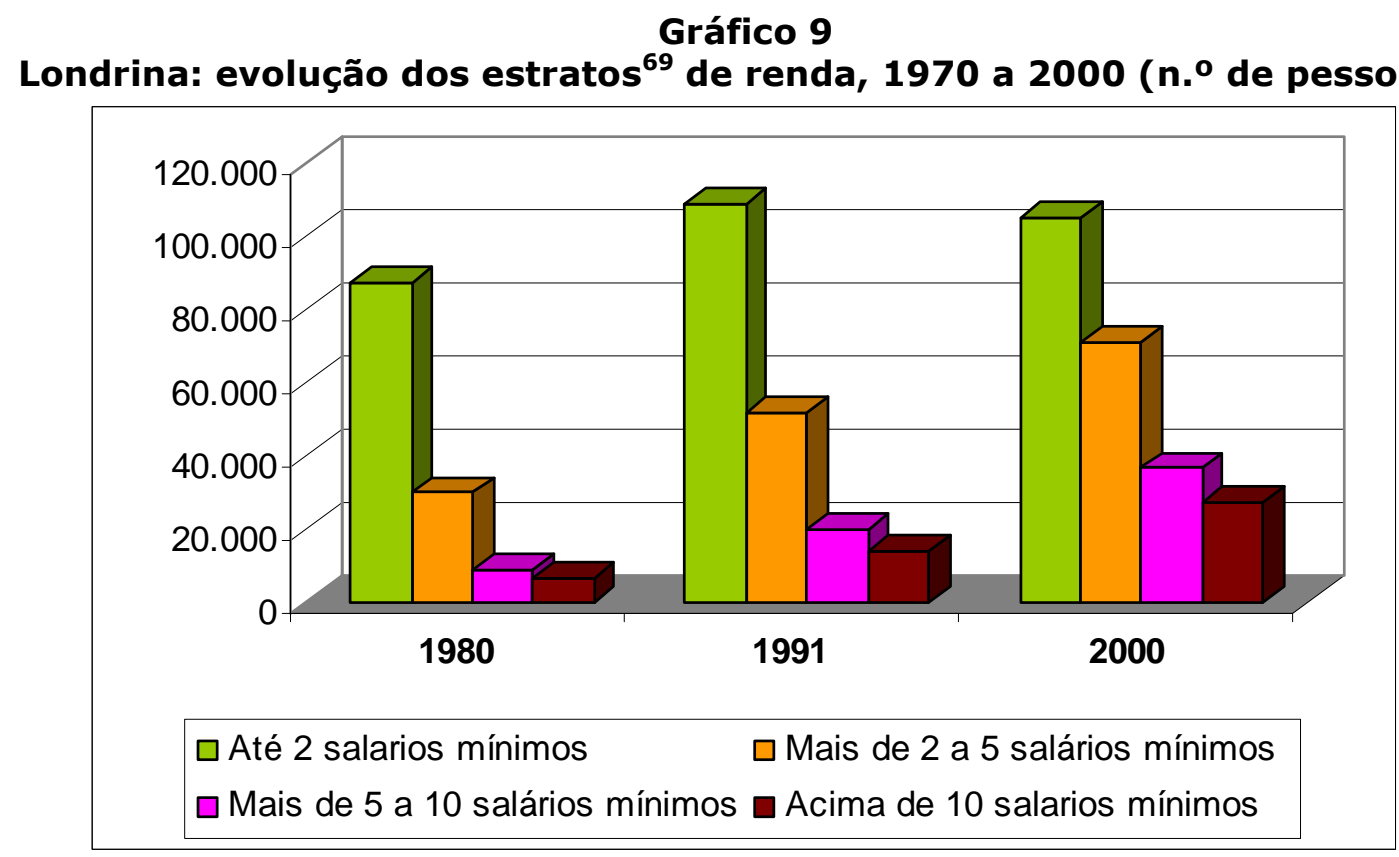

Fonte: IBGE, Censos Demográficos.

O gráfico evidencia o crescimento contínuo dos estratos de renda a partir de dois salários mínimos. Evidencia também a formação de um contingente de pessoas com rendimentos entre dois e cinco salários mínimos que cresceu de maneira acelerada. É importante registrarmos também o crescimento contínuo dos que ganhavam acima de cinco

\footnotetext{
${ }^{69}$ Trata-se do rendimento médio dos responsáveis por domicílios particulares permanentes
} 
salários, o que corresponde, grosso modo, ao crescimento da classe média.

A distribuição dos estratos no ano 2000 indicava uma cidade em que o conjunto de pessoas com rendimentos acima de dois salários cresceu mais do que o de pessoas que auferiam ganhos inferiores a dois salários; estrato que declinou ligeiramente nos anos 1990, mas seguiu sendo o mais numeroso.

O tamanho do grupo que aufere rendimentos de até dois salários mínimos se aproxima de um contingente de 100 mil pessoas. Por sua magnitude, esse dado pode ser considerado fundamental para a existência dos circuitos, particularmente do circuito inferior.

De fato, nos países subdesenvolvidos, a magnitude do crescimento
demográfico urbano tem um papel relevante sobre o mercado. Se
os pobres, pela precariedade de suas rendas, têm uma demanda
menos freqüente, o seu número sempre crescente, traz consigo
um efeito de compensação. Se estivessem espalhados pelo
território ou, mesmo, subdivididos em pequenas aglomerações, os
custos de distribuição da produção do que consomem seriam muito
mais elevados. As maiores cidades reduzem esses custos para
todas as firmas e esse fato é mais relevante para as empresas
não-hegemônicas. (SANTOS, 1994, p. 103)

A coexistência de diferentes estratos de renda merece destaque porque aponta a existência de outro elemento importante na estruturação dos circuitos: a formação de segmentos que, em função de seu poder aquisitivo, demandarão as atividades do circuito superior, os que demandarão as atividades do circuito inferior e de uma classe média que transitará entre eles.

Outro processo importante do período técnico-científico pós1970 em Londrina foi a expansão e diversificação do meio construído. O meio construído reflete as desigualdades e a diferenciação entre as classes sociais e a complexidade da economia urbana; discutiremos essa questão a seguir. 


\title{
2.1.5 - A rápida expansão e a diversificação do meio construído
}

Considerando os dados censitários, entre 1970 e 2000, a população urbana cresceu a uma razão de aproximadamente 9.000 novos habitantes por ano, saltando de 163.528 hab. em 1970 para 433.369 hab. em 2000. As conseqüências na área construída da cidade não demoraram a se fazer sentir. A área urbana construída, que era de $34,6 \mathrm{Km}^{2}$ em 1970, se amplia e em 1999 atinge a marca de $114,53 \mathrm{~km}^{70}$, possibilitando um forte desenvolvimento da construção civil e das atividades do mercado de imóveis, e de todos os problemas inerentes à urbanização acelerada (OLIVEIRA e FRESCA, 2005, p.60).

A expansão do meio construído, sua fragmentação e diversidade são fatores importantes para o pleno desenvolvimento dos circuitos da economia urbana. Uma concepção de meio construído adequada à discussão dos circuitos deve levar em conta a determinação social desse elemento urbano, particularmente a complexidade de seus valores de uso e de troca e as conseqüências disso para a economia urbana.

\begin{abstract}
Marx insiste en que no debemos confundir el capital fijo con el capital inamovible (los barcos y las locomotoras son capital fijo aunque se mueven, mientras que algunos elementos del capital circulante, como la energía hidráulica, tienen que usarse in situ). Sin embargo, tenemos que considerar la "función especial" que desempeña el capital fijo bajo el capitalismo en general y en la economía de las naciones en particular. Una porción del fondo de consumo (viviendas, parques, etc.)

Esto nos leva a la concepción de un ambiente construido que funciona como un vasto sistema de recursos creado por los seres humanos, que comprende valores de uso cristalizados en el paisaje físico, que se pueden utilizar para la producción, el intercambio y el consumo. Desde el punto de vista de la producción, estos valores de uso pueden considerarse como precondiciones generales de la producción y como fuerzas directas dentro de ellas. (HARVEY, 1990, p.258)
\end{abstract}

\footnotetext{
${ }^{70}$ Os dados sobre a área urbana construída foram obtidos da pesquisa do grupo IMAP/UEL - Evolução da área urbana construída de Londrina, 1987 a 1993.
} 
Segundo Harvey (1990) sob o modo capitalista de produção os diversos elementos que compõe o meio construído se convertem em mercadorias, só que dotadas de propriedades muito específicas.

Considerados puramente como mercancías, los elementos del ambiente construido exhiben ciertas características peculiares. La inmovilidad en el espacio significa que una mercancía no puede moverse sin que se destruya el valor cristalizado en ella. Los elementos del ambiente construido tienen la posición o ubicación espacial como un atributo fundamental, en vez de incidental [...] Además, la utilidad de determinados elementos depende de su ubicación en relación con otros, las tiendas, casas, escuelas, y fábricas deben estar razonablemente próximas entre sí. Toda la cuestión del orden espacial del ambiente construido tiene que ser considerado entonces; la decisión de dónde poner un elemento no se puede divorciar de donde están los otros.

Entonces, el ambiente construido tiene que ser considerado como una mercancía mixta, completa y geográficamente ordenada (HARVEY, 1990, p.238).

Os interesses dos diversos mercados e atividades econômicas que se formam a partir do meio construído podem entrar em rotas de colisão ou compor alianças para benefício mútuo. O mercado imobiliário e a construção civil, interessados no valor de troca do meio construído, podem confrontar-se com os interesses individuais e coletivos voltados para o seu valor de uso.

As prerrogativas dos proprietários de grandes áreas urbanas podem colidir com o capital industrial que requer essas áreas para implantar suas unidades de produção na cidade. Esse foi um dos fatores que moveu a Prefeitura de Londrina a criar as áreas industriais (CILOS), como parte da política de incentivo à industrialização.

No tocante às alianças, o mais comum é que capitais de diferentes procedências se interessem pelos ganhos que a produção do meio construído Ihes possibilita. Em virtude de o ambiente construído, ou meio construído como preferimos chamar, ser em parte um bem público e, em parte, um bem particular, as ações em torno do meio construído requerem a participação efetiva e/ou a intermediação do Estado.

No capitalismo, via de regra, cabe ao Estado fazer a coordenação dos diversos interesses, atuando na mediação dos conflitos e minimizando os efeitos das contradições que sejam potencialmente 
perigosas para a estabilidade do modo de produção. A ação do Estado também possibilita processos de valorização e desvalorização das parcelas do meio construído. As atribuições das prefeituras, tais como estabelecer zoneamentos, regulamentar as construções e autorizar a abertura de loteamentos têm a capacidade de definir, por exemplo, as áreas da cidade em que a verticalização pode ocorrer, ou a construção de um Shopping Center, de um conjunto habitacional ou de um parque. As ações do poder publico municipal podem alterar, portanto a composição de uma dada área da cidade e com isso confirmar, estabelecer ou frear as tendências de valorização e desvalorização.

A dinâmica da economia urbana londrinense, redefinida pela urbanização acelerada e concentrada, pela industrialização e pelas transformações na divisão territorial do trabalho, passou a requerer ajustes em relação ao meio construído. A industrialização, principalmente, teve grande impacto na expansão físico-territorial de Londrina por meio da criação de áreas especificamente destinadas a essa atividade. A primeira área industrial criada na cidade foi o Parque das Indústrias Leves (CILO I), aprovado pela Prefeitura em 1969. Foram deslocadas para essa área muitas indústrias antes localizadas na zona leste da cidade as quais, com a expansão da área central, tornaram-se vizinhos indesejáveis.

No inicio dos anos 1980, o CILO I havia incorporado 63 empresas, que empregavam 1840 pessoas (RAZENTE, 1984, p.290 a 293). Essa área industrial e posteriormente a implantação de uma central de abastecimento, o CEASA, produziram alguns efeitos na expansão de Londrina na direção leste, aproximando-a cada vez mais de uma efetiva conurbação com Ibiporã. Alguns conjuntos habitacionais, a exemplo do conjunto Lindóia e do Mister Thomaz, acompanharam a tendência gerada pela implantação do CILO I e estenderam a periferia da cidade na direção leste.

O CILO II, com 242 mil m², foi implantado a partir de 1973 e deu prosseguimento à política de transferência de empresas de outras partes da cidade. Situado na zona oeste da cidade, na saída para o 
município de Cambe, essa área industrial reforçou a tendência estabelecida por algumas grandes empresas de se implantarem junto a BR 369, e proporcionou o incremento do processo de conurbação entre Londrina e Cambe. A implantação do CILO II favoreceu o incremento da ocupação de vários loteamentos próximos, dando origem a bairros populosos, como Jardim Bandeirantes e o Jardim Leonor.

Essa mesma parte da cidade, a zona oeste, receberia ainda - CILO III, onde se localiza a empresa Cacique de café Solúvel, intensificando ainda mais expansão da cidade na direção de Cambé. No início dos anos 1980, os CILOS II e III, abrigavam respectivamente, 15 e 22 empresas em funcionamento.

Ao sul da cidade, o CILO V, assim como as outras áreas industriais, atuou com um extensor urbano consolidando a expansão da cidade nessa direção juntamente com o conjunto habitacional denominado Cafezal e vários bairros derivados de loteamentos populares: Jardim Franciscato, Perobal, Parque das Indústrias, etc. A ocupação intensiva da zona sul é mais recente (anos 1990) do que a expansão para as zonas norte e oeste.

No início dos anos 2000 os quatro CILOS reuniam $80 \%$ das 269 indústrias que usufruíram das benesses da política de incentivo a industrialização, a qual destinou mais de 2 milhões de $\mathrm{m}^{2}$ de área urbana para uso industrial (RAZENTE, 1984, p.299). 
Mapa 8

Londrina: distribuição das áreas industriais - CILOS, 2008

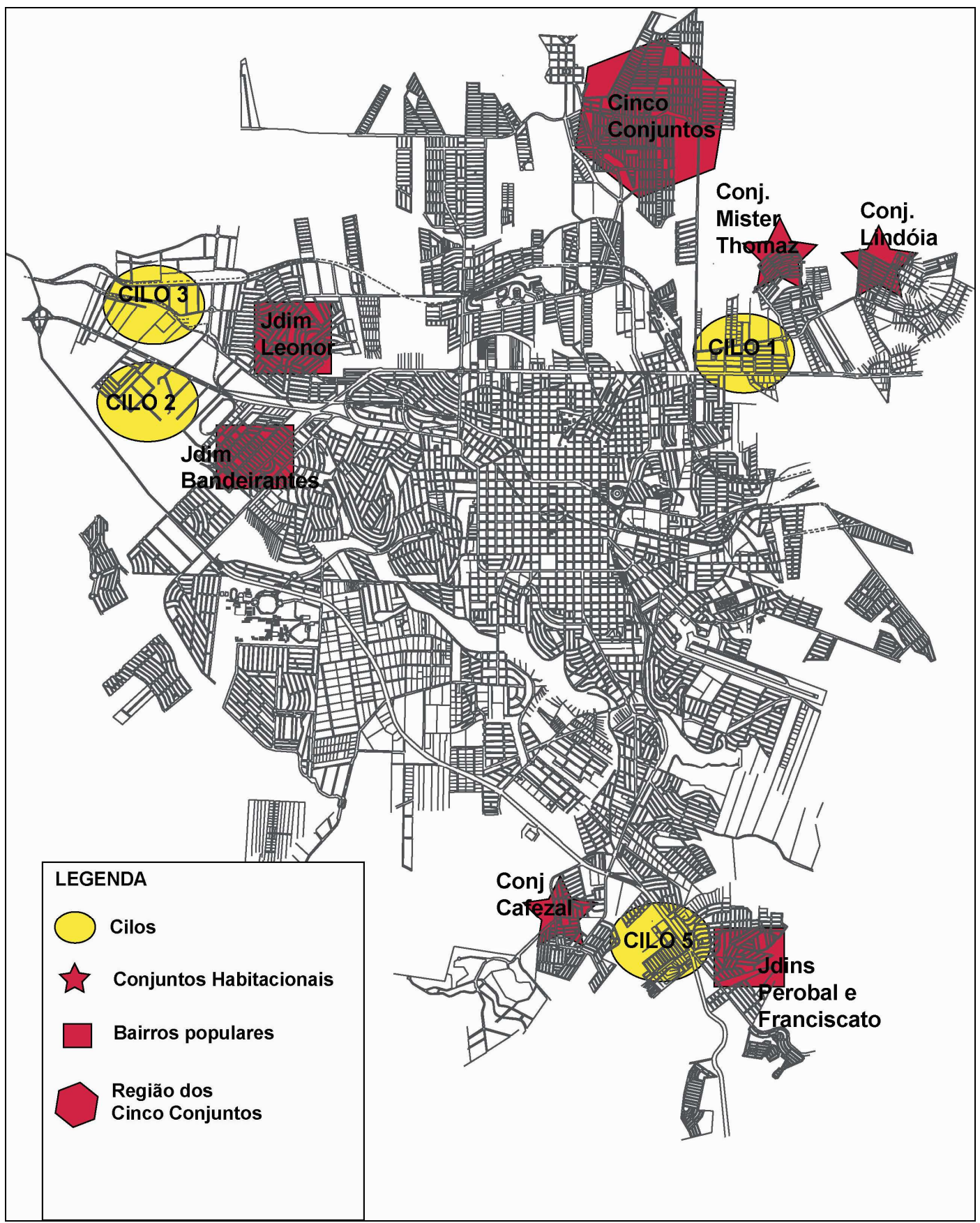

Fonte: Prefeitura de Londrina.

Observação: o CILO IV foi construído em área que atualmente pertence ao município de Tamarana e por isso não consta do mapa. 
A distribuição dessas áreas na cidade foi um fator de intensificação da segregação socioespacial, na medida em que, sua localização em áreas periféricas reforçou a tendência de afastamento dos segmentos de baixa renda do Centro Principal. No entorno dos CILOS, formaram-se bairros derivados, principalmente, de loteamentos populares e de conjuntos habitacionais. Lentamente essas áreas foram adquirindo estrutura e se consolidando por meio de equipamentos de consumo coletivo e, assim, nucleando futuras expansões que seguiriam o padrão de ocupação definido pela associação entre os CILOS - loteamentos populares - conjuntos habitacionais.

Se as zonas leste, oeste e sul tiveram sua paisagem caracterizada pela presença dessas áreas de concentração industrial associadas a loteamentos populares e conjuntos habitacionais, a estruturação da zona norte da cidade foi marcada pela reunião de diversos conjuntos habitacionais que, ao longo do tempo, adquiriam identidade própria - a região dos cinco conjuntos ${ }^{71}$.

A formação da zona norte foi profundamente influenciada pela política habitacional do início dos anos 1970 que, com recursos federais do Banco Nacional da Habitação (BNH), possibilitou à COHAB de Londrina construir 32 conjuntos habitacionais e 11.600 unidades residenciais entre 1970 e 1980, a maior parte deles na zona norte (OLIVEIRA e FRESCA, 2005, p. 107). Surgiu, desse modo, uma nova referência urbana na periferia da cidade, um novo vetor de crescimento permitindo que a cidade absorvesse parte significativa da massa de migrantes que acorreu a Londrina. Apenas a título de exemplo, segundo o Censo demográfico de 1980 , nada menos que $60 \%$ da população de Londrina (183.227 hab.) era de migrantes.

Além dos conjuntos habitacionais a expansão horizontal de Londrina foi alimentada pela produção de loteamentos lançados no mercado pela iniciativa privada tanto para as classes médias quanto para

\footnotetext{
${ }^{71}$ O novo setor da cidade construído a partir do ano de 1977 foi assim denominado por ser constituído de cinco conjuntos habitacionais que são os seguintes: Ruy Virmont Carnascialli, Milton Gavetti, Parigot de Souza I e II, João Paz e Semiramis B. Braga contendo milhares de unidades habitacionais.
} 
as pessoas com menores rendimentos. Na década de 1970, foram aprovados 96 loteamentos, boa parte deles lançados no mercado a partir de 1975, coincidindo com a modernização da agricultura e o período de intensa migração. (OLIVEIRA E FRESCA, 2005, P.62). As loteadoras e as construtoras que se multiplicaram na cidade nesse período são parte importante do circuito superior de Londrina ${ }^{72}$.

A partir dos anos 1980, Londrina conheceu também uma rápida expansão vertical. Na conjuntura recessiva da década de 1980, a construção de edifícios se revelou um grande negócio. O processo de verticalização parece ter se difundido pelas cidades médias do interior do país nos anos 1980 .

\begin{abstract}
A evolução do crescimento da produção imobiliária vertical nos anos de 1980, ampliando no interior do Estado de São Paulo (Sposito, 1991a) uma forma de habitat urbano tipicamente metropolitano, pode ser considerado o primeiro movimento significativo na direção da realização dos interesses fundiários e imobiliários nas cidades médias, em termos de mercado e de mudanças das práticas socioespaciais. Do ponto de vista das relações centro periferia, a "onda" da verticalização só fez reforçar o paradigma que orientou a expansão territorial e a estruturação urbana das cidades médias, pois esse produto imobiliário -o apartamento- foi vendido associado a uma localização central, entendida aqui em seu sentido mais amplo, qual seja o das áreas que mais próximas ao centro de comércio e serviços são as melhor equipadas com infraestrutura, equipamentos e serviços urbanos. (SPÓSITO, 2004, p. 131)
\end{abstract}

As características do processo de verticalização no interior paulista descritas por Maria Encarnação B. Spósito (2004) se aplicam à Londrina. A massa de altos edifícios construídos na cidade está concentrada nas proximidades do Centro Principal. Essas áreas valorizadas desfrutam de todos os equipamentos, serviços e infraestruturas que compõem o valor de uso e de troca do meio construído.

Mark Gottdiener (1993, p.245) afirma que a "atividade imobiliária reflete o papel do espaço tanto como fonte de criação quanto de realização de mais-valia", argumentando que os interesses em torno

\footnotetext{
${ }^{72}$ Uma das construtoras formada a partir de capitais locais, a Plaenge, atualmente realiza operações no mercado imobiliário de outras unidades da federação e até no exterior, construindo edifícios no Chile.
} 
do meio construído crescem e se diferenciam na medida em que a produção do espaço se constitui em possibilidade de criar riqueza nova, e não apenas se apropriar da riqueza em circulação. Dessa forma seria útil distinguir grandes empreendedores e incorporadores imobiliários de construtores eventuais ou especuladores que atuam no mercado fundiário urbano.

A abordagem de Gottdiener (1993) contribui para a interpretação da formação de grandes grupos de investidores que realizam grandes operações imobiliárias atuando sobre o valor de uso complexo das parcelas do meio construído, tendência que se verifica em Londrina.

A força dos capitais reunidos em grandes fundos de investimento imobiliário possibilita que áreas desvalorizadas da cidade, mas que são dotadas de "boa localização", guarnecidas com infraestruturas e equipamentos urbanos possam, em curto período de tempo, passar a abrigar novos usos e objetos como edifícios residências de alto padrão associados a shopping centers, escritórios entre outros. ${ }^{73}$

A construção e incorporação de edifícios são, portanto, negócios lucrativos a ponto de atrair vultosos capitais. Isso é fato também para cidades médias como Londrina. A inflação acelerada e os sucessivos planos de estabilização dos anos $1980^{74}$ e seus congelamentos de preços de salários tiveram para a construção civil um impacto diferente daquele que se verificou em outros ramos.

Mas a presença de elevadas taxas de inflação na primeira metade
dos anos 1980 criou até certo ponto, condições favoráveis para a
construção civil. Como? Tendo em vista que mês a mês alteravam-
se preços dos insumos necessários à construção do prédio, podia-
se realizar as compras antecipadamente cujos preços seriam
mantidos, mas os valores das mensalidades/prestações pagas
pelos consumidores eram corrigidos. Acrescente-se ainda a
possibilidade de aplicações no mercado financeiro - o overnight -
que permitia a correção do dinheiro/capital em níveis elevados.

\footnotetext{
${ }^{73}$ Uma operação desse tipo vem sendo anunciada em Londrina no âmbito do chamado Projeto Marco Zero, que irá valorizar toda um setor muito próximo ao Centro Principal que abrigava indústrias e moradias de pessoas pobres.

${ }^{74}$ Apenas a título de exemplo, vale lembrar que nos anos 1980 foram criados os Plano Cruzado, Plano Bresser e plano Verão, todos voltados para o controle da inflação.
} 
Criava-se um volume de dinheiro/capital que, até certo ponto, dava às construtoras condições favoráveis para fazer os investimentos (OLIVEIRA e FRESCA 2005, p. 136).

Em Londrina o resultado dessa conjuntura favorável à construção civil foi a intensa verticalização. Entre 1971 e 1996, 1334 edifícios foram construídos na cidade. Mais da metade deles (51\%) era de edifícios de apenas 4 pavimentos. Os edifícios entre 5 e 14 pavimentos abarcaram 39\% do total. O uso residencial predominou - 55\% dos edifícios. O uso misto (comercial e residencial) abarcou $27 \%$ dos edifícios construídos no período (OLIVEIRA e FRESCA, 2005 p.129 a 140).

Nos anos 1990, o processo de expansão da cidade ganhou novos conteúdos, refletindo a complexidade da estrutura social da cidade. Dentre esses conteúdos, estão os loteamentos fechados também chamados de condomínios fechados. Esses empreendimentos residenciais que se concentraram na região sudoeste da cidade, são voltados principalmente para segmentos da população que detém alto poder aquisitivo e para classe média alta.

Os conteúdos sociais e econômicos da periferia urbana das cidades
médias começam a se redesenhar, em meados de 1980 , com as
primeiras iniciativas de implantação de loteamentos fechados
nessas cidades, mas, de fato, só vão se instaurar, de forma mais
plena, no decorrer dos anos de 1990 , quando aumenta o número
desses loteamentos e o de pessoas que passam a viver neles, já
que essa se torna a nova forma de habitat, sucedendo a "onda" da
verticalização e se constituindo num fenômeno associado aos
segmentos de alto e médio poder aquisitivo, a exemplo do que já
havia se iniciado, em diferentes cidades latino-americanas, a partir
dos anos de 1960 (SPÓSITO, 2004, p. 131).

Como pudemos ver, a partir dos anos 1970, Londrina passa por um contínuo processo de expansão físico-territorial no qual se combinaram a intensa verticalização e a expansão horizontal, os quais, por sua vez, realimentaram o processo de ampliação da área urbana. 


\section{2 - Os circuitos da economia urbana em Londrina no período técnico-científico.}

A premissa básica da teoria dos circuitos da economia urbana é que estes são produto de sucessivos processos de modernização (SANTOS, 1979, p.25). As manifestações das modernizações não são as mesmas em todos os lugares. A cidade de Londrina e parte da região Norte do Paraná foram constituídas no contexto de um amplo e complexo processo de modernização que produziu um arranjo espacial regional e uma divisão de trabalho muito particulares (como vimos no capítulo 1 ).

A cafeicultura paranaense, inserida na dinâmica da industrialização tardia em um país subdesenvolvido, propiciou uma intensa acumulação e concentração de riquezas e recursos em Londrina. No contexto dessa primeira modernização o berço da economia urbana era o meio rural.

A partir dos anos 1970, sobre as modernizações anteriores incidem outras modernizações e formas de repartir o trabalho, com suas técnicas e necessidades próprias. Constituídas no período da cafeicultura, entre as décadas de 1940 e 1960, a cidade e sua economia urbana incorporaram, a partir dos anos 1970, novas bases e novos conteúdos. Até esta parte do trabalho procuramos discutir a constituição dessas bases a partir das modernizações que se sucederam em Londrina.

Cabe agora analisar os conteúdos, isto é, os circuitos propriamente ditos. Para tanto, analisaremos a estruturação dos circuitos em relação a duas variáveis: a produção e o consumo em Londrina. 


\subsection{1 - Circuitos e produção}

As modernizações do período técnico-científico pós-1970 redefiniram a produção em Londrina e no seu entorno regional. Como discutimos, as novas especializações produtivas trouxeram para economia urbana londrinense as agroindústrias, as cooperativas e outras manifestações da divisão de trabalho hegemônica ${ }^{75}$. A nova divisão do trabalho, associada às transformações no meio construído e à urbanização intensa e concentrada, criaram as bases para o desenvolvimento dos circuitos em Londrina, especialmente de um robusto circuito superior que passou a ser composto também pelas agroindústrias e cooperativas.

Analisando a industrialização de Londrina e municípios vizinhos a partir da composição do valor adicionado, Cláudio R. Bragueto (2007) identifica os ramos mais importantes nos anos 1970.

Os ramos mais importantes são aqueles que se vinculam ao setor
agropecuário, em que a modernização da agricultura propiciou a
instalação na região de grandes grupos agroindustriais. Dessa
forma, a indústria de produtos alimentares, têxtil e química, que
em 1975 já geravam $77,8 \%$ do valor adicionado da indústria do
Aglomerado Urbano-Industrial de Londrina, em 1985 ampliaram a
participação para $84 \%$ (BRAGUETO, 2007, p.98)

No contexto das atividades industriais, além das agroindústrias, as principais manifestações da produção no interior da trama dos circuitos da economia urbana de Londrina foram as indústrias produtoras de bens de consumo não duráveis (alimentos e vestuário) e a construção civil. Nesses ramos, existem diferentes divisões do trabalho.

Com as transformações da cafeicultura a partir de meados dos anos 1960 vários capitais aplicados naquela atividade foram deslocados para outras atividades como a especulação imobiliária, a construção civil, o comércio e a indústria. O número e a diversidade desses capitais se expressa nos gêneros industriais que foram se configurando e expandindo em Londrina.

\footnotetext{
75 A título de ilustração vale lembrar a criação de duas instituições de pesquisa em Londrina: o Instituto Agronômico de Paraná (IAPAR) em 1972 e a Empresa Brasileira de Pesquisas Agropecuárias especializada na pesquisa da soja (EMBRAPA_soja) em 1976.
} 
Gráfico 10

Londrina: número de estabelecimentos da indústria de transformação, 1960 a 1985

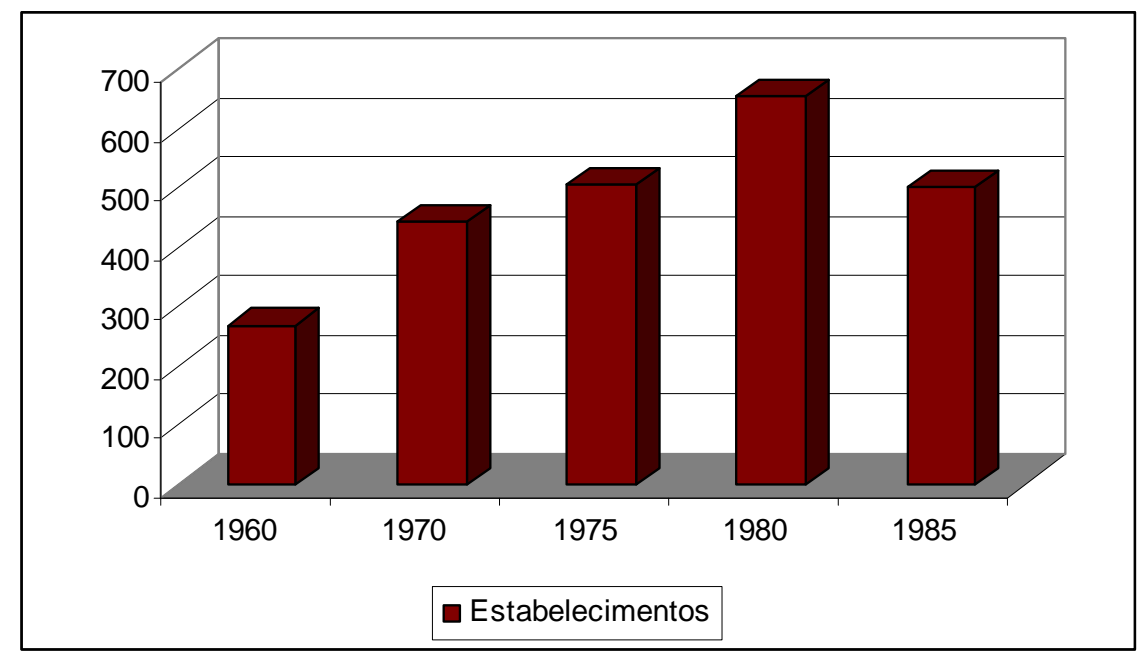

Fonte: IBGE, Censos Econômicos.

\section{Gráfico 11}

Londrina: pessoal ocupado na indústria de transformação, 1960 a 1985 ( $n .^{\circ}$ de pessoas)

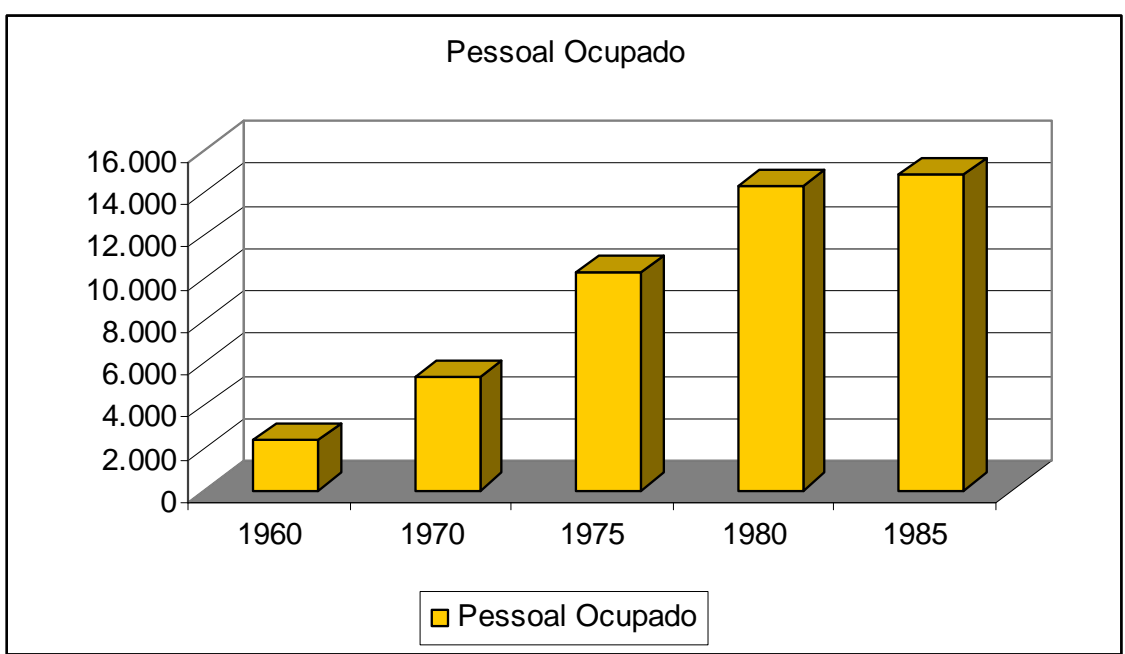

Fonte: IBGE, Censos Econômicos.

Os novos estabelecimentos, alguns de grande porte, redefinem o uso do solo e a distribuição dos fluxos no interior da cidade. Novas formas de intermediação ${ }^{76}$ ligadas á produção industrial reforçam a centralidade adquirida por Londrina no período da cafeicultura. Com o

\footnotetext{
${ }^{76}$ Um exemplo é a compra de maquinário e insumos em São Paulo e a ampliação de mercado que as indústrias em Londrina realizam ao vender produtos paras regiões de avanço da fronteira agrícola como o Mato Grosso do Sul e também o oeste do Paraná a partir dos anos 1970 (NAKAGAWARA, 1972)
} 
aumento do pessoal ocupado na indústria as relações de trabalho assentadas no assalariamento foram se tornando predominantes.

Nakagawara (1972, p.107) analisando a expansão das indústrias em Londrina, afirma que, a partir dos anos 1960, verificou-se a presença de grandes indústrias cujos produtos alcançavam o mercado nacional e internacional, como a Companhia Cacique ${ }^{77}$ de Café Solúvel, a Londrifarma do ramo farmacêutico, a Herbitécnica e a Fertiplan que produziam insumos agropecuários, e a cofres Barão. Nos anos 1970 e 1980, outras empresas locais também prosperaram como Indúsfrio que fabrica equipamentos de refrigeração e a Indrel que fabrica equipamentos para laboratórios e hospitais. No entanto, essa não é a única manifestação da divisão de trabalho na industrialização de Londrina.

Outra pesquisadora que se interessou pela expansão da atividade industrial em Londrina é Ana Maria Chiarotti Almeida (1980, p.43). A autora mostra, em termos quantitativos, a predominância das empresas de pequeno porte na indústria de transformação. Mais da metade das empresas existentes no início dos anos 1970, isto é, 56\% delas, empregavam até 10 pessoas. Outros 30\% empregavam de 10 a 50 pessoas, dessa forma, $86 \%$ das indústrias eram micro ou pequenas empresa (ALMEIDA, 1980, p. 44).

Ana Cleide C. Cesário (1978) que estudou as indústrias implantadas no CILO 1 (Parque das Indústrias Leves), confirma a predominância das micro e pequenas empresas naquela área industrial. Sobre a organização interna dessas empresas, esclarece:

\footnotetext{
77 A Cia cacique foi fundada no final do ano de 1959 por Horacio Sabino Coimbra e outros sócios. O Sr. Coimbra era também sócio do Banco Nacional do Paraná e Santa Catarina juntamente com Aderbal Ramos da Silva, deputado federal e político muito influente em Santa Catarina e presidente da Casa Bancária Hoepcke. Segundo o professor Evaldo Pauli "A firma Hoepcke já fora representante de diversos bancos de outras praças, mesmo estrangeiras, desde os tempos da Província. Tais eram Banco Alemão Transatlântico (Rio de Janeiro), Banco Germânico; Bank of London and South America Ltd (Rio de Janeiro). Criada a Casa Bancária Hoepcke Ltda., esta transformou-se, em 1952, no Banco Nacional do Paraná e Santa Catarina, sede em Londrina (PR), com a participação também de outros grupos financeiros, e capital de 200 milhões de cruzeiros." Vale ressaltar a precoce presença de capital financeiro de origem regional, formado pela aliança com capital bancário estrangeiro no período em que as economias regionais mantinham vínculos fortes com as economias de capitalismo maduro por meio das exportações de gêneros agrícolas e matérias primas.
} 
Como vimos o, pequeno empresário se movimenta dentro de um quadro do qual já temos algumas características. Dirige empresas com baixo índice de burocratização, com características familiares, com número reduzido de empregados numa estrutura hierárquica notadamente simples (CESÁRIO, 1978, p.84).

As empresas analisadas por Cesário (1978) vendiam seus produtos no mercado regional, realizavam poucas inovações e, apenas algumas empresas maiores, faziam algum tipo de propaganda de suas atividades. Essas características estariam em sintonia com as formas de participação das empresas no mercado.

Pelo fato de as empresas pertencerem a um processo industrial novo - o londrinense - voltadas paras áreas menos dinâmicas da produção industrial, cobrindo setores de consumo não atendidos pela indústria mais desenvolvida, parece-nos ser este tipo de organização consentâneo em relação ao processo como um todo (CESÀRIO, 1978, p.79).

Essas análises revelam o circuito inferior e o circuito superior marginal no contexto da industrialização de Londrina. As empresas instaladas no Parque das Indústrias Leves - CILO 1 apresentam praticamente todas as características de empresas do circuito inferior, até mesmo a mão de obra empregada era composta predominantemente de migrantes recém chegados da zona rural, com pouca ou nenhuma qualificação (CESARIO, 1978, p. 82). Em síntese a modernização da economia urbana de Londrina pela via da industrialização criou as condições para o desenvolvimento e a articulação dos circuitos em Londrina. 


\subsection{2 - Circuitos e consumo}

No que tange aos circuitos da economia urbana, vale ressaltarmos que o consumo e a circulação, considerando a importância que guardam para a reprodução ampliada do capital e da sociedade como um todo, respondem por parte significativa das atividades e do trabalho urbano.

O tema do consumo remete, via de regra, às discussões sobre a formação da sociedade de consumo de massa nos países do Primeiro Mundo como um dos pontos nevrálgicos da reestruturação capitalista após a grande crise de 1929. Em seus aspectos básicos, a constituição das sociedades de consumo é parte do advento do Capitalismo Monopolista ${ }^{78}$. Também a urbanização intensiva tem papel decisivo nesse processo. No período pós-guerra, a disseminação do consumo de massa nos países desenvolvidos se fez de forma entrelaçada ao planejamento estatal e à internacionalização da economia capitalista por meio da expansão da empresas multinacionais.

Uma vez consolidada, a sociedade de consumo, irmã siamesa do consumo de massa, impôs novos comportamentos em relação à posse e ao uso dos bens. Na "sociedade dos produtores" a durabilidade e as possibilidades de recuperação eram propriedades valorizadas dos bens de consumo (BAUMAN, 2008, p.44). Numa sociedade em que 0 consumo se encontra ligado à noção do efêmero a lógica própria à sociedade dos produtores foi subvertida. As famílias que, em meio à massificação do consumo, tornaram-se unidades de consumo passaram a ser submetidas à exposição permanente de técnicas de persuasão social como a propaganda ${ }^{79}$.

\footnotetext{
${ }^{78} \mathrm{O}$ advento do consumo de massa não seria possível sem as tecnologias oriundas da Segunda Revolução industrial e as transformações que provocaram nos transportes e nas comunicações.

${ }^{79}$ Esse é o sentido principal do conceito de indústria cultural segundo Theodor Adorno e Max Horkheimer:

"O cinema, o rádio e as revistas constituem um sistema. Cada setor é coerente em si mesmo e todos o são em conjunto. [...] Os interessados inclinam-se a dar uma explicação tecnológica da indústria cultural. O fato de que milhões de pessoas participam dessa indústria imporia métodos de reprodução que, por sua vez, tornam inevitável a disseminação de bens padronizados para a satisfação de necessidades iguais. O contraste técnico entre poucos centros de produção e uma recepção dispersa condicionaria a organização e o planejamento pela direção. Os padrões teriam resultado originalmente das necessidades dos consumidores: eis por que são aceitos
} 
A difusão da sociedade de consumo de massa para os países do Terceiro Mundo se fez por meio de processos de modernização incompletos (SANTOS, 2005). Essa difusão desencadeou ciclos de intenso crescimento econômico e transformação de hábitos e valores cotidianos, mas não internalizou nos países subdesenvolvidos a correspondente melhora e universalização nas formas de atendimento as necessidades de saúde, educação, habitação, transporte coletivo, entre outras. Mas, principalmente, não trouxe para a maioria dos trabalhadores ganhos salariais compatíveis com os novos patamares de produtividade alcançados pelo trabalho.

No Brasil a forte concentração da renda e a difusão limitada do consumo às classes médias são aspectos característicos da modernização incompleta por meio da qual se implantaram no país certos elementos de uma sociedade de consumo de massa nos anos 1970.

A modernização dos consumos se manifestou em Londrina através de uma intensa sofisticação dos serviços e das atividades comerciais, incluindo as empresas que vendem máquinas e equipamentos para as novas especializações produtivas de Londrina e região. Essa sofisticação reflete uma primeira fase de intensificação do consumo que fica mais ou menos restrita às classes médias.

As transformações da base produtiva regional e do arranjo espacial com a urbanização concentrada trouxeram à tona as necessidades inerentes às novas formas de consumo produtivo. As estratégias das empresas comerciais frente às novas necessidades reforçaram a tendência de concentração nas maiores cidades do Paraná, dos ramos comerciais que vendiam máquinas, aparelhos e equipamentos

sem resistência. De fato, o que o explica é o círculo de manipulação e da necessidade retroativa, no qual a unidade do sistema se torna cada vez mais coesa. O que não se diz é que o terreno no qual a técnica conquista seu poder sobre a sociedade é o poder que os economicamente mais fortes exercem sobre a sociedade. A racionalidade técnica é hoje a racionalidade da própria dominação. Ela é o caráter compulsivo da sociedade alienada de si mesma. Os automóveis, as bombas e o cinema mantêm coeso o todo e chega o momento em que seu elemento nivelador mostra na própria injustiça à qual servia. Por enquanto, a técnica da indústria cultural levou apenas à padronização e á produção em série, sacrificando o que fazia a diferença entre a lógica da obra e a do sistema social. Isso, porém, não deve ser atribuído a nenhuma lei evolutiva da técnica enquanto tal, mas á sua função na economia atual" (ADORNO, HORKHEIMER, 1985, p. 114) 
agrícolas, industriais, comerciais e de uso técnico e profissional. Nos anos 1980, as cidades com mais de 100 mil hab. reuniam mais de $40 \%$ estabelecimentos varejistas e $83 \%$ dos estabelecimentos atacadistas desses ramos comerciais (IPARDES, 1983).

Em Londrina a presença de empresas que comercializam máquinas e equipamentos agrícolas pode ser notada a partir de meados dos anos 1970 acompanhando a expansão da soja e do trigo na região. Há pelo menos oito empresas diferentes que vendem tratores, máquinas e implementos agrícolas que atuam na cidade desde os anos $1980^{80}$.

Do ponto de vista das empresas que atendem ao consumo cotidiano dos habitantes, as transformações são marcantes. Diversas redes comerciais vêem juntar-se às Casas Pernambucanas, instalando-se na cidade no período pós-1970 ${ }^{81}$ : Casas Buri, Lojas Americanas, Hermes Macedo, Riachuelo, Lojas Arapuã, Armarinhos Paulista, A Exposição. Lojas "tradicionais" de Londrina como as casas Fuganti e Viscardi, passaram a se organizar como supermercados, forma moderna de organização do comércio varejista que se multiplicou na cidade. A rede Peg Pag, uma das pioneiras no sistema de autoserviço no Brasil, implantou-se no Shopping Com-Tour, inaugurado em 1973 (PINTAUDI, 1987, p.44).

O próprio Shopping Com-Tour que tinha como lojas mais importantes o supermercado Peg $\mathrm{Pag}^{82}$ e as Lojas Brasileiras, era uma inovação importante no circuito superior da cidade. Constituía um empreendimento imobiliário capaz de influir na estruturação urbana, definindo o conteúdo de vetores de ocupação e/ou de edificação do meio construído. Pintaudi (1987, p.32) indica que, até o final dos anos 1970, os shopping centers do país estavam concentrados em apenas cinco cidades: São Paulo, Salvador, Belo Horizonte, Brasília e Londrina. Como se pode

\footnotetext{
${ }^{80}$ Com base na pesquisa de Ronqui (1990, p.46) sobre a comercialização de máquinas agrícolas em Londrina verificamos pela lista telefônica e internet quais empresas elencadas pela autora ainda comercializam esses equipamentos na cidade atualmente. Encontramos oito empresas, são elas: Nortrac - Bavária; Transparaná, Mayrink Goes; Paranámotor, Cacol, Giamack, Agril e Máquinas Pereira.

${ }^{81}$ Conforme a publicação da Prefeitura de Londrina "Dados estatísticos de Londrina, 1974. Londrina: Secretaria de Planejamento, 1974. (31 p.)

${ }^{82}$ O supermercado Peg Pag vindo de São Paulo seria adquirido pelo Grupo Pão de Açúcar no final dos anos 1970 e passaria se chamar supermercado Jumbo.
} 
notar, Londrina era a única cidade em que havia um shopping e que não era uma capital.

A tendência do comportamento espacial de supermercados e shopping centers de convergirem para um mesmo local se reforçou nos últimos anos. As questões de status, a possibilidade de encontrar diversos produtos e lojas em um só lugar, o estacionamento e outras facilidades contribuíram para a junção espacial dos empreendimentos, reduzindo custos e reforçando a atratividade.

A importância atual dos supermercados é assinalada por Santos e Silveira (2001, p.150) no trecho que segue:

Os supermercados são, hoje, elos fundamentais nas cadeias de distribuição e produção, pois participam das diversas instâncias, criando marcas, agindo como oligopsônios em algumas produções, modificando calendários de pagamentos e comandando assim uma importante parcela do comércio varejista. O número de supermercados cresceu 7,8 vezes entre 1966 e 1976 (997 lojas e 7.800 lojas, respectivamente). Em 1998 eram 51.500 supermercados mostrando em 22 anos um crescimento de 6,8 vezes. Hoje eles respondem por $85 \%$ do abastecimento nacional de produtos de grande consumo e por 655 mil empregos.

O número de supermercados em Londrina, entre 1974 e 1993, cresceu mais de $300 \%$, passando de 15 para 65 estabelecimentos ${ }^{83}$ (LINARDI, 1995, p.66). Esse crescimento resultou da incorporação à economia urbana de diversos pequenos supermercados, evidenciando assim a convivência de capitais mercantis de diferentes expressões também nas atividades ligadas ao consumo. Concomitantemente, também foram implantados alguns hipermercados em Londrina, acentuando a segmentação da economia urbana. É o caso dos hipermercados do Grupo Muffato, de Cascavel, em 1975, e da rede Condor, no início dos anos 1980 (SILVA, 2006, p.91 e BLUM, 2006, p.78).

Nos anos 1990, na esteira dos supermercados locais e das redes nacionais, ocorreu a implantação de um estabelecimento da rede multinacional francesa Carrefour dentro do recém-inaugurado Shopping

\footnotetext{
${ }^{83}$ Os dados apresentados por Maria Cecília Nogueira Linardi (1995) referem-se a tabela 4 de sua tese de doutorado e foram obtidos em levantamento feito pela autora com base nas listas telefônicas do município.
} 
Catuaí. Mais uma vez, hipermercados e shopping center convergiram para uma mesma localização na cidade, especializando funcionalmente certos pontos do meio construído.

William Ribeiro da Silva (2006) que estudou a centralidade e a estruturação urbana em Londrina e Maringá afirma que em Londrina:

Considerando as duas lógicas urbanas analisadas, just in time e sobrevivência, são absolutamente imbricadas numa relação que compõe a totalidade, pois, temos, no aumento da complexidade da estruturação urbana, uma ampliação significativa das contradições do modo de produção, acirrando as diferenças que passam a se expressarem por meio de novas centralidades. (SILVA, 2006, p.239)

Identificamos o que Ribeiro da Silva (2006) denomina como lógica do just in time e lógica da sobrevivência com os circuitos superior e o inferior respectivamente. O sistemas de ação do circuito superior obedecem aos imperativos do just in time, sinônimo de fluidez territorial e de tempos rápidos, próprios ao processo de globalização (SANTOS, 2004). No circuito inferior predominam os tempos lentos, as formas de ação baseadas nos recursos locais, especialmente o meio construído e a presença numerosa dos pobres. Contudo, é o entrelaçamento dos circuitos que faz com que a totalidade do meio construído, isto é, toda a cidade, seja espaço da economia urbana. Esse argumento é decisivo, pois dessa forma, o meio construído, em sua diversidade, torna-se capaz de revelar os circuitos, particularmente o circuito inferior ${ }^{84}$.

De forma semelhante ao que ocorrera no comércio, houve a ampliação quantitativa e qualitativa de diversos serviços, com destaque para os setores de saúde e educação. José Arthur Rios (1980) pesquisador do IBGE que auxiliou a elaboração do planejamento urbano na cidade nos anos 1980, observou a sofisticação dos serviços que acompanharam os bairros onde residiam segmentos da classe média e outros ainda mais abastados.

Outro fator importante foi a diversificação do comércio e o aparecimento de atividades terciárias destinadas a servir à classe

${ }^{84}$ Essa discussão também se aproxima daquela elaborada por Roberto Lobato Correa (1995) acerca da articulação e fragmentação que caracterizam o espaço urbano. 
média emergente: institutos de beleza, ginástica, terapia de várias naturezas, escritórios, clínicas, boutiques, ao lado de mansões. Essa invasão terciária é nítida na Avenida Higienópolis[...] (RIOS, 1980, p. 10).

Em meados dos anos 1980, a publicação Perfil do Município, da Secretaria Municipal de Planejamento de Londrina, descrevia os serviços de saúde e educação do município da seguinte forma:

Londrina é um pólo regional de bens e serviços, destacando-se por seu atendimento médico (12 hospitais com 1508 leitos 1986), educacional (282 escolas, incluindo 6 de $3 .{ }^{\circ}$ grau com 87.958 alunos na educação regular - 1987), sistema de transportes, comunicações e infraestrutura. (LONDRINA, 1986, p.17)

Maria Cecília N. Linardi (1995, p.67) e José Humberto Tavares $(2001,147)$ que estudaram aspectos gerais da atividade de serviços em Londrina, ressaltam a importância dos autônomos e sua divisão entre os que possuíam formação superior, os que apresentavam qualificação de nível médio e os que detinham pouca ou nenhuma qualificação. Mais uma vez a segmentação é registrada. O último grupo, mais numeroso, abrangia $74 \%$ dos 25 mil autônomos registrados na prefeitura em 1998, segundo Tavares (2001). Os de nível médio representavam $14 \%$ e os que detinham formação superior, somavam $11 \%$ do total. Para Linardi (1995), os números relativos ao pessoal com formação de nível médio e superior, refletiam a necessidade de mão-deobra com certo grau de especialização.

Linardi (1995) apontou o crescimento das atividades de serviços ligadas às finanças e às necessidades técnicas e burocráticas das empresas $^{85}$.

\footnotetext{
${ }^{85}$ O gráfico 12 revela a crescente participação das atividades de serviços na economia urbana londrinense a partir dos anos 1980, indicando inclusive o inicio do processo de difusão das novas técnicas inerentes ao meio técnico científico informacional, como as empresas de processamento de dados e lojas para artigos de informática.
} 
Gráfico 12

Londrina: atividades de serviços selecionadas, 1974 a 1993

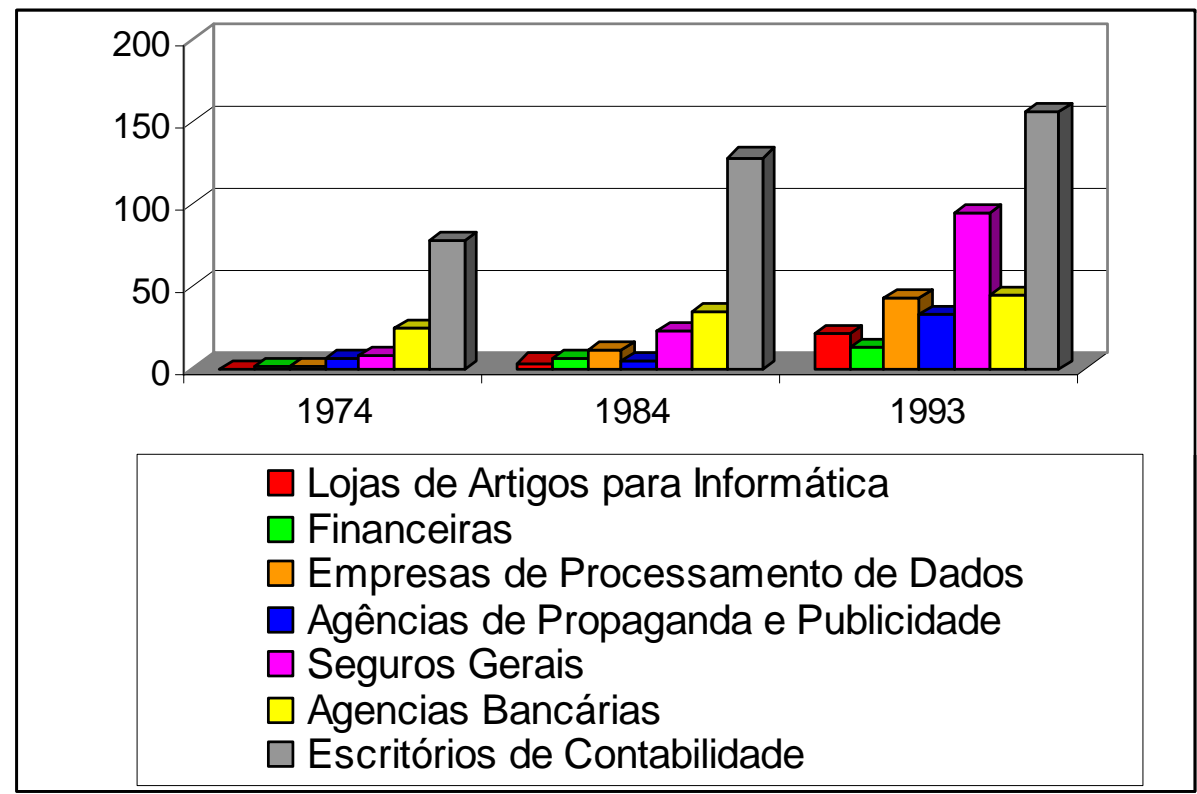

Fonte: Maria Cecília Linardi (1995, p.69)

Em paralelo à ampliação e sofisticação das atividades ligadas ao consumo ocorreu a contínua ampliação do meio construído, que, nas áreas periféricas abrigava o pequeno comércio, os serviços pessoais, enfim o terciário banal. Essas atividades dispersas pela cidade, presentes também na área central, são muito mais difíceis de analisar, de revelar suas minúcias e desvelar seus processos e, como demonstrou William Ribeiro da Silva (2006), também produzem centralidade e participam do processo de estruturação e reestruturação da cidade ${ }^{86}$ (SPÓSITO, 2007).

A expansão do meio construído é simultaneamente a possibilidade de segmentação das atividades de consumo. À diversidade do meio construído acaba por corresponder à diversidade que caracteriza as atividades de consumo dos circuitos. Em Londrina, no período técnico-

\footnotetext{
${ }^{86}$ Segundo Maria E. Beltrão Spósito (2007) é preciso atentar para a diferença entre reestruturação urbana e reestruturação da cidade:

"Tenho chamado de estruturação ou reestruturação urbana as dinâmicas e processos atinentes aos espaços regionais elou ocorridos no âmbito das redes urbanas; como estruturação ou reestruturação da cidade, compreendo dinâmicas e processos que ocorrem na escala intra-urbana. Assim, procuro articular duas escalas geográficas, distinguindo-as, mas objetivando considerar as múltiplas determinações que entre elas se estabelecem."
} 
científico pós-1970, a formação de centros de bairros é o registro mais fiel da segmentação das atividades de consumo no contexto da economia urbana. Descrevendo a zona norte de Londrina, William R. da Silva (2002, p. 122) diz o seguinte:

De inicio, por se tratar de uma área popular, portanto, de
moradores que possuem uma menor mobilidade devido as
dificuldades de transporte, os estabelecimentos comerciais e
prestadores de serviços que foram se instalando, eram de
propriedade dos moradores locais, que os abriam nas frentes de
suas casas, buscando abastecer a população com produtos de
primeira necessidade, principalmente, alimentos.

Ao longo do período, principalmente a Avenida Saul Elkind, tornou-se o núcleo a partir do qual se formou o primeiro subcentro de Londrina (SILVA, 2002). As dinâmicas do meio construído e dos circuitos se misturam. A formação do subcentro na zona norte, que se iniciou com atividades do circuito inferior ligado ao consumo, foi paulatinamente alterada pela valorização que o próprio circuito inferior, juntamente com a melhoria dos equipamentos públicos e infraestruturas, ajudou a consolidar: "Porém, na medida que houve a implantação de infraestrutura, a área foi sendo valorizada, e houve a instalação de filiais dos estabelecimentos do Centro Principal de Londrina" (SILVA, 2002, p122).

O desenvolvimento da zona norte de Londrina é emblemático das relações entre a estruturação da cidade e a dinâmica do período técnico-cientifico pós-1970, no qual a intervenção do Estado nas questões fundamentais da habitação, do transporte e da urbanização em geral, associada à expansão do emprego e de relações salariais, foram essenciais para a integração ao modo de vida urbana, de milhares de migrantes rurais expulsos pela modernização do campo.

O circuito inferior e o circuito superior se aproximaram na zona norte de Londrina compondo o subcentro nucleado na Avenida Saul Elkind. Coexistem naquela parte da cidade atualmente um camelódromo, um hipermercado do Grupo Mufatto, lojas de redes comerciais instaladas no Centro Principal da cidade e nos shopping centers, agências bancárias 
e uma grande variedade de estabelecimentos comerciais e de serviços populares.

Aos domingos uma enorme feira invade essa que é a principal Avenida da zona norte. Nessa feira, misturam-se a venda de gêneros alimentícios pelos próprios produtores rurais, feirantes tradicionais que adquirem suas mercadorias no Ceasa e uma infinidade de barracas que vendem produtos eletrônicos, DVD de filmes e Shows, artesanato e diversas outras coisas.

Os circuitos da economia urbana convivem e se reforçam entrelaçados pela contigüidade que o meio construído lhes impõe. Isso ocorre com intensidade na zona norte. Dificilmente esse nível de interação seria possível em outra parte de Londrina. Os conjuntos habitacionais, a difusão das infraestruturas, a presença de uma numerosa população pobre, definem os contornos dessa convivência. Essa situação particular resultou da dinâmica própria da primeira fase de expansão do meio técnico-cientifico em Londrina, mas atualmente o quadro é outro.

Nos anos 1990 a ruptura provocada pelas crises, pelo projeto neoliberal e pela intensificação do processo de globalização trouxe importantes transformações para a dinâmica da economia urbana londrinense. Os circuitos superior, inferior e superior marginal serão redefinidos e reestruturados com o advento do período atual. 


\section{CAPÍTULO 3 \\ O período atual e as transformações na dinâmica dos circuitos}

\section{1 - Uma breve caracterização do período atual}

O período atual se caracteriza pela expansão do meiotécnico científico-informacional e pelas transformações na divisão social e territorial do trabalho em suas diversas escalas. As variáveis que contribuem para completar essa caracterização são, entre outras, as seguintes: a relação estreita entre ciência e técnica, a informação, as finanças, a diversificação e intensificação dos consumos, o entrelaçamento das redes em termos organizacionais e técnicos, o desemprego crônico, uma nova forma de produzir a pobreza e o empobrecimento relativo, as formas da cooperação/competição entre empresas, as relações entre mercado e Estado ${ }^{87}$.

Nos anos 1990, uma segunda fase de difusão do meio técnico científico-informacional aumentou a densidade técnica do meio construído em Londrina (SANTOS, 2004). Como resultado dessa expansão a economia urbana londrinense incorporou-se às correntes da globalização.

A ciência, a tecnologia e a informação estão na base mesma de todas as formas de utilização e funcionamento do espaço, da mesma forma que participam da criação de novos processos vitais e da produção de novas espécies (animais e vegetais). É, também, a informatização, ou antes, a informacionalização do espaço. A informação tanto está presente nas coisas como é necessária à ação realizada sobre essas coisas. Os espaços assim requalificados atendem sobretudo aos interesses dos atores hegemônicos da economia e da sociedade, e assim são incorporados plenamente as correntes da globalização (SANTOS,2005, p.148)

\footnotetext{
${ }^{87}$ Segundo Silveira $(2005$, p.192) “As bases normativas da moderna divisão do trabalho renovam as relações entre Estado e mercado, aproximando o pêndulo mais de uma cooperação e menos de uma disputa. Desenhamse pontos e áreas propícios à ação de uma firma global que, agindo de forma independente ou amiúde em parceria com oligopólios nacionais, metamorfoseia os imperativos da sua micro economia em políticas macroeconômicas da nação [...]”"
} 
Para analisar as transformações da economia urbana no período atual, é preciso, mais uma vez, levar em conta a dinâmica do território e a caracterização de Londrina como uma importante cidade média da Região Concentrada.

Os novos papéis de intermediação que as cidades acolhem com o processo de globalização ${ }^{88}$ e com a expansão do meio técnicocientífico-informacional são de fundamental importância para a estruturação e reestruturação dos circuitos.

Em Londrina, os diferentes tipos de fluxos, como, por exemplo, os fluxos que têm como suporte redes de alta tecnologia e os fluxos de pessoas e mercadorias que se realizam a partir de trabalho extenuante de trabalhadores com moto, remetem a diferentes atores, diferentes possibilidades de ação e a divisões de trabalho que se encontram e se sobrepõem.

As combinações entre esses fluxos distintos atuam como modernizações que estruturam e reestruturam os circuitos da economia urbana, criando novas atividades modernas e atividades novas, mas que não são modernas. Tais atividades se entrelaçam no cotidiano da cidade. Um motoboy contratado como terceirizado junto a uma empresa de entregas urbanas complementa o trabalho e aumenta a produtividade de uma empresa que produz softwares para clientes no exterior.

Empregamos o termo reestruturação no sentido da criação de novas atividades e/ou a extinção de alguma atividade, redefinindo assim os contornos de cada circuito, o que resulta em ampliação das atividades que integram cada circuito. Também as mudanças de conteúdo com a incorporação de novos objetos e ações às atividades que já existiam, podem ser consideradas no contexto da reestruturação dos circuitos da economia urbana.

\footnotetext{
${ }^{88}$ Segundo Spósito et..alli (2007a, p.40) “Assim, é provável que, paralelamente à manutenção dos papéis regionais das cidades médias,de elos entre as cidades maiores e menores, a partir de fluxos de natureza hierárquica, tenham se estabelecido novos papéis, desenhados por fluxos de outros tipos, orientados por dinâmicas de complementaridade ou de concorrência entre cidades da mesma rede ou de redes urbanas diferentes."
} 
A proposição dessas noções remete às formulações de Edward Soja (1993).

A reestruturação, em seu sentido mais amplo, transmite a noção de uma "freada", senão de uma ruptura nas tendências seculares, e de uma mudança em direção a uma ordem e uma configuração significativamente diferentes da vida social, econômica e política. Evoca, pois, uma combinação seqüencial de desmoronamento e reconstrução, de desconstrução e tentativa de reconstituição, provenientes de algumas deficiências e perturbações nos sistemas de pensamento e de ação aceitos. A antiga ordem está suficientemente esgarçada para impedir os remendos adaptativos e convencionais e exigir, em vez deles, uma expressiva mudança estrutural (SOJA, 1993, p.193 e 194)

A concepção de Edward Soja (1993) refere-se a uma escala que abarca sociedade como um todo e a períodos históricos mais longos. O que pretendemos, nesse caso, é apenas fazer uma aproximação entre a concepção de reestruturação proposta por Edward Soja (1993) com a noção de reestruturação dos circuitos, adequando as escalas à reflexão sobre o fenômeno dos dois circuitos na contemporaneidade.

Interessam-nos, particularmente, as indicações de Edward Soja (1993) quanto ao sentido de "mudança em direção a uma ordem e uma configuração significativamente diferentes da vida social" como conteúdos dos processos seqüenciais de desmoronamento e reconstrução decorrentes de perturbações na ordem vigente que estão implícitos no conceito de reestruturação. Interessam-nos menos o sentido de freada e ruptura a que o autor parece condicionar os processos de mudança social.

A intenção é refletir sobre as conexões e relações concretas entre as reestruturações na divisão do trabalho e na rede urbana com as reestruturações nos circuitos. O ponto de onde parte o olhar que constrói a análise é o interior da cidade, é o meio urbano. 


\section{2 - A expansão do meio técnico-científico- informacional e a contextualização de Londrina como cidade média}

O aumento da fluidez territorial criou as bases para que novos usos do território se instalassem e se difundissem para além das grandes metrópoles, produzindo transformações importantes nas cidades médias brasileiras. Silveira (2004a, p.3) afirma que:

[...] la intensa urbanización, la reorganización del Estado y de la economía, la monetarización de la economía y de la sociedad que se va completando, los agregados de ciencia y técnica e información a la vida social y al territorio, y la diversificación y profundización de los consumos son datos nuevos del período, que alteran la naturaleza del espacio em que los circuitos de la economia urbana se desarollan. Hoy, las metrópolis surgen como la sede de comandos vinculados a actividades modernas, pero al mismo tiempo como el principal escenario de actividades de aglomeración - menos capaces de movilidad espacial, o más capaces de florecimiento local - asociadas al circuito superior marginal y al circuito inferior de la economía urbana.

El importante aumento de las ciudades millonarias y de las grandes ciudades medias (alrededor de medio millón de habitantes) permite la diversificación y la densificación de la división del trabajo. Cuanto mayores y más populosas las ciudades, mas capaces son de abrigar una extensa gama de actividades y de contener una lista mayor de profesiones (Santos y Silveira, 2001), autorizando una mayor complejidad de los circuitos de la economía urbana en el período actual.

As novas condições do período permitiram que houvesse uma relativa desconcentração da atividade industrial, que as migrações se tornassem mais difusas no território, que redes de diversos tipos redefinissem fluxos materiais e imateriais, modernos e não modernos, contribuindo para o desenvolvimento de novas especializações produtivas que se somam às anteriores, produzindo superposição de divisões de trabalho (SANTOS, 2004, p.135).

Tais eventos geram novas autorizações, novas possibilidades para a ação, que se tornam mais evidentes quando se compara o período atual com meados dos anos 1970, quando Milton Santos publicou seu trabalho sobre os circuitos da economia urbana. 
Àquela altura, o autor indicava que, com exceção dos casos em que o Estado atuava diretamente, promovendo a industrialização, havia dificuldades para que investimentos geradores de modernas indústrias produtoras de bens de consumo, redes comerciais ou prestadores de serviços modernos fossem atraídos para as chamadas cidades intermediárias ${ }^{89}$.

As cidades médias, por sua vez, eram atingidas em sua capacidade de comando da vida de relações com seu entorno regional pela progressiva integração do território por meio de redes de transporte e pela concentração da atividade industrial nas grandes metrópoles, redundando na invasão dos mercados das cidades médias por produtos fabricados alhures.

Milton Santos (1979, p.244) enfatizava que as cidades que ele denominava como intermediárias, eram fortemente afetadas pela difusão do consumo, tolhidas em suas possibilidades de desenvolvimento pela exacerbada concentração econômica e demográfica nas metrópoles nacionais e sofriam a ausência de atividades fabris do circuito superior e uma limitada presença de atividades comerciais e de serviços modernos. Essa descrição não é mais possível nos dias atuais, pois suas bases foram claramente alteradas pelas sucessivas modernizações que se verificaram nas últimas décadas.

No período atual, cresce o número de cidades médias as quais abrigam empresas multinacionais e importantes concentrações de modernas atividades industriais, comerciais e/ou de serviços. A modernização do campo, a partir de meados dos anos 1960, permitiu que concentrações de agroindústrias e indústrias de produtoras de insumos se constituíssem no interior do país, redefinindo a distribuição regional da produção agrícola e industrial. O próprio Milton Santos (1996) ao discutir a urbanização brasileira nos alerta para essas mudanças profundas do

\footnotetext{
${ }^{89}$ Em meados dos anos 1970, a respeito das cidades intermediárias, Milton Santos (1979, p. 243), afirmava que: "Com efeito, no atual período tecnológico, a cidade regional, chamada ainda de cidade "média", torna-se cidade intermediária. Seu poder de comando e sua influência sobre a região diminuem e ela se torna, cada vez mais, um relé da metrópole.".
} 
território. Tecendo algumas considerações sobre as cidades médias no período atual, Milton Santos e Maria Laura Silveira nos dizem que elas são:

[...] pontos de interseção e superposição de verticalidades e horizontalidades. Elas oferecem os meios para o consumo final das famílias e administrações e o consumo intermediário das empresas. Assim, elas funcionam como entrepostos e fábricas, isto é, como depositárias e como produtoras de bens e de serviços exigidos por elas próprias e por seu entorno. (SANTOS e SILVEIRA, 2001, p. 280)

O novo contexto do desenvolvimento das cidades médias vem sendo alvo de um amplo debate. Uma parte desse debate está voltada para a discussão do conceito de cidades médias. Spósito (2001) indica a necessidade de incrementar o debate sobre as cidades médias no contexto contemporâneo da urbanização brasileira. A autora aponta para a trajetória da noção de cidades médias, fortemente calcada em critérios demográficos, úteis, é bem verdade, como parâmetros para identificar esses "novos objetos", porém insuficientes para aprofundar o debate. A autora propõe, então, algumas indicações para que se possa passar da noção a um conceito mais profícuo, em torno do qual a discussão possa se aprofundar.

Para Sanfeliu e Torné (2004) o conceito de cidades médias está paulatinamente sendo substituído pelo de "ciudades intermedias".

El adjetivo intermedio/intermediario, cuyo empleo se inició en los medios académicos a mediados de los ochenta, dilata el significado de la denominación a la que sustituye: ciudad media (GAULT, M, 1989; BOLAY, J.C., et alt., 2003). La dimensión, la talla demográfica y la extensión física eran las variables que contribuían, mayormente, en la delimitación/definición de ciudad media, variables que actualmente se consideran demasiado rígidas y estáticas. Por el contrario, intermedio/intermediario introducen tres nuevas dimensiones:

- añaden la idea de que el potencial e importancia de la ciudad no dependen tanto de su talla demográfica como del modo en que esta se articula con el resto de elementos del sistema: la capacidad de crear relaciones y tejer una red, así como las características de las mismas.

- dan valor e introducen aspectos más dinámicos y estratégicos que incorporan nuevas posibilidades para la autoafirmación, el reforzamiento de la ciudad-región y la apertura/consolidación a otros niveles: regional, nacional e, incluso, internacional. 
- suponen la sustitución del sentido estático y notablemente jerarquizado que otorgaban las teorías más clásicas al concepto de sistema urbano por una nueva idea más abierta, dinámica e interactiva[...]

No Brasil o debate sobre as cidades médias apontou caminhos semelhantes, especialmente no que concerne à inserção dessas cidades na divisão do trabalho em suas várias escalas. Também acrescentou a necessidade de se discutirmos como essa inserção repercute sobre os processos de estruturação e reestruturação da cidade, ou seja, sua incidência na escala intra-urbana (SPÓSITO, 2007).

Analisando as cidades médias no Estado de São Paulo, Maria E. Beltrão Spósito (2004) sugere critérios para definir melhor o conceito de cidades médias:

[...] o que se compreende como cidades médias só pode ser considerado no plano conceitual e a partir de uma análise que contemple a situação geográfica da aglomeração ou centro urbano que a constitui, seus papéis econômicos regionais, suas relações intermediárias entre cidades pequenas e metrópoles, bem como seus papéis político-administrativos (SPÓSITO, 2004, P.127).

Acompanhando os critérios propostos podemos identificar Londrina como uma cidade média. Essa identificação é possível em função de sua situação geográfica, tanto no que se refere à distância física das Regiões Metropolitanas de Curitiba e São Paulo, quanto por seus papéis na divisão territorial do trabalho, que, como vimos, desde o período da cafeicultura, conferiram à cidade um poder de polarização sobre seu entorno regional que se reforçou ao longo do tempo.

A segunda fase de expansão do meio técnico-científicoinformacional, a partir dos anos 1990, e o alargamento da região concentrada por meio dos mais diversos tipos de redes, da urbanização intensa e da desconcentração da industrialização, que atinge de forma seletiva algumas áreas do território, vêm permitindo uma redefinição e uma ampliação do número e das características das cidades médias. O conceito de cidade média não deve, portanto, ser tomado de maneira estática. 
Nesse amplo contexto de determinações, não se trata de classificar as cidades médias como se pode classificar as de porte médio por seu tamanho demográfico, mas de avaliar continuamente seus papéis numa divisão regional do trabalho que se encontra em período de rápidas transformações, redefinindo continuamente o próprio conceito de cidade média. Assim sendo, a aplicação do conceito de cidade média a uma cidade ou aglomeração urbana é sempre relativa no tempo e no espaço (SPÓSITO, 2004, P.127).

No caso de Londrina, a atualização de sua condição como cidade média, reflete os novos papéis de intermediação que a cidade adquiriu com a implantação de novas atividades produtivas e de consumo na última década. A imbricação entre as atividades desenvolvidas no período anterior, anos 1970 e 1980, com as novas atividades permite falar na presença de divisões de trabalho sobrepostas que se articulam no território a partir de diversas combinações entre verticalidades e horizontalidades (SANTOS, 2004).

A complexidade da economia urbana aumenta na proporção em que essas combinações se multiplicam. Esse dado do período atual redefine as formas de subordinação, complementaridade e competição entre os circuitos da economia urbana. 


\section{3 - As modernizações atuais e as repercussões sobre o circuito superior da economia urbana}

A partir de meados dos anos 1990, novas modernizações incidiram sobre Londrina e, com elas, vieram novas especializações produtivas. Essas transformações não se fizeram no vazio; elas se realizaram a partir das condições herdadas do período anterior, os anos 1970 e 1980.

As infraestruturas para o fornecimento de energia, saneamento básico e telefonia não estavam saturadas e apresentavam boa disponibilidade até o início dos anos 1990. O número de telefones fixos, por exemplo, cresceu continuamente. Em 1988 havia mais de 50 mil telefones fixos instalados e em 2002 atingiam a cifra de 160 mil telefones. Os novos sistemas técnicos agregaram-se aos anteriores aumentando o conteúdo de ciência e tecnologia incorporado ao meio construído.

A telefonia móvel está presente na cidade desde 1991 graças à empresa pública local (SERCOMTEL). Em 1995 havia em Londrina 20 mil aparelhos celulares que, desde então, cresceram continuamente, atingindo em 2003, a marca de 70 mil celulares operados pela empresa local (BRAGUETO, 2007, p.72).

A modernização que a Companhia Paranaense de Energia elétrica (COPEL) fez em seus sistemas internos de controle e administração da geração e distribuição da energia elétrica deu origem a uma extensa rede de fibras óticas que interligou as principais cidades do estado à Curitba. Essa rede, combinada com a rede de fibras óticas instalada pela TELEPAR (FRESCA, 2004, p.236), permitiu uma nova escala para a circulação de informações, imagens, ordens, dados de diversas empresas constituídas em rede, cuja topologia pôde ser mais facilmente ampliada em todo Paraná graças às disponibilidades e facilidades criadas pelas redes de fibras óticas ${ }^{90}$.

\footnotetext{
${ }^{90}$ Segundo informa a própria COPEL em seu sitio na Internet estão entre os usuários conectados a sua rede as seguintes empresas: Sercomtel, Claro, Vivo, GVT, Brasil Telecom, Embratel, TIM, Impsat, Oi, Intelig, Nextel, Geodex entre outras.
} 
As novas tecnologias de comunicação e informação, a exemplo da convergência entre computadores, softwares, telefonia, transmissão de imagens e pacotes de dados permitiram que novas redes técnicas fossem criadas e, com elas, também novos serviços como, por exemplo, os que atendem a grandes empresas e bancos, o Renpac e o Transdata. Conforme José H. Tavares (2001, p.196) esse serviços já estavam em operação em Londrina em meados dos anos 1990.

Um dos dados novos do período é a privatização da produção das infraestruturas. Diversos serviços, como a telefonia, a energia elétrica e a operação de rodovias e ferrovias, passaram ao controle da iniciativa privada. Empresas globais que atuam no setor escolheram cidades médias para instalar seus centros de comando. É o caso da Global Telecom em Londrina (FRESCA, 2004). Também a multiplicação dos pedágios alterou as condições de circulação encarecendo pequenas viagens, reforçando algumas dificuldades para a economia de cidades pequenas e repercutindo nas relações e fluxos entre essas cidades e cidades médias como Londrina. A forma como os pedágios distribuem-se no Paraná, penalizando as pequenas cidades, dá-nos uma indicação de como, no período atual, por conta do projeto neoliberal, o papel do Estado foi redefinido para abrir caminho ao mercado e as preocupações com o território como um todo passaram para segundo plano.

Os novos sistemas técnicos criaram condições para que diversas empresas dos setores de comunicação e informática se instalassem ou se desenvolvessem em Londrina, formando um Arranjo Produtivo Local (APL) de Tecnologia da Informação a partir de $2006^{91}$.

Entre as empresas de tecnologia da informação de Londrina predominam empresas que empregam menos de 10 trabalhadores $^{92}$, o que não significa que não sejam empresas dinâmicas do ponto de vista do

\footnotetext{
${ }^{91}$ Segundo informações do sítio do APL de Ti de Londrina (www.apltilondrina.com.br), havia na cidade, em 2004, 149 empresas do setor de informática das quais 83 no ramo de processamento de dados. A maioria era de microempresas. Fogem a essa caracterização duas empresas criadas no período anterior, ou seja, antes de meados dos anos 1990, que são a Mabtec e a Exactus, que empregam respectivamente, 35 e 87 pessoas e sua atuação abrange o mercado nacional. Outras empresas menores também têm se revelado dinâmicas como a LINT criada pro empresários locais que atende sobretudo empresas Transnacionais.

${ }^{92}$ Segundo informações do sitio do APL Ti de Londrina.
} 
seu faturamento. Além de empregar poucas pessoas o novo setor é bastante seletivo no que se refere às qualificações exigidas para contratação da força de trabalho. Os conhecimentos em informática e eletrônica são fundamentais para o candidato que disputa uma dessas vagas.

Outro aspecto importante de algumas empresas desse setor são suas conexões verticais com a cidade e a região. Uma grande empresa indiana, a Satyam, se instalou na cidade em 2008. A empresa emprega 30 profissionais e trabalha com o desenvolvimento de softwares e suporte aos produtos que comercializa. A empresa pretende dobrar o faturamento atual de U\$ 15 milhões por ano e seus clientes são principalmente empresas norte-americanas ${ }^{93}$.

A empresa indiana, ao que parece, manterá poucas relações com as outras atividades da economia urbana de Londrina. Apoiada nas novas redes técnicas suas conexões principais serão com os EUA e a Índia. Essa parece ser uma característica do circuito superior que as novas especializações produtivas que estão se configurando na cidade estão reforçando e aprofundando: a verticalidade (SANTOS, 2004).

Além das empresas também as universidades têm papel importante no desenvolvimento desse setor. A Universidade Estadual de Londrina tem o curso de Ciências da Computação, e a Universidade Federal Tecnológica do Paraná, criada recentemente também forma profissionais na área de Tecnologia da Informação, compondo assim círculos de cooperação (SANTOS e SILVEIRA, 2001). Tais círculos reforçam a presença desse novo ramo da produção na cidade.

Ao longo dos anos 1990, o circuito superior da cidade incorporou novos componentes como resultado da política de atração de investimentos praticada pela Prefeitura. O trecho a seguir identifica algumas das novas empresas presentes na cidade.

\footnotetext{
${ }^{93}$ Informações disponíveis em <<http://portal.rpc.com.br/jl/geral/conteudo.〉> acesso em julho de 2009.
} 
Empresas instaladas em outras regiões transferiram suas sedes para o município, aproveitando as oportunidades existentes, a exemplo da Dixie Toga, Itap-Bêmis, Atlas, entre outras.

Além disso, empresas como a Milênia Agro Ciências, Allvet Química, Lavanderia Clarear, Hussmann Thermoking já instaladas no município, ampliaram suas instalações e atividades, gerando empregos, riqueza e desenvolvimento local, criando oportunidades para outras empresas menores, como clientes, fornecedores ou terceirizados. Em 2003, a cidade ganhou outra multinacional, a Ingersoll-Rand, maior fabricante de compressores de ar para uso industrial no mundo, trocando o Rio de Janeiro por Londrina. A instalação da Ingersoll-Rand representou investimentos de R\$10 milhões e gerou 35 empregos diretos. Desde outubro, a unidade exporta para a Colômbia e espera, até 2005, abastecer também os mercados do Chile, Argentina e Uruguai. Para isso, a multinacional pretende dobrar o tamanho da estrutura implantada na cidade, nos próximos cinco anos. A região de Londrina também está recebendo, especificamente em Cambé $(13 \mathrm{~km}$ a oeste de Londrina), a Hexal, que é a segunda maior fabricante de medicamentos genéricos da Alemanha. Está presente em 42 países e será a primeira do setor a funcionar no Paraná. (LONDRINA/CODEL, 2004, p.22)

A presença de multinacionais do setor de embalagens como a Dixie-Toga indica o aumento da complexidade da economia urbana londrinense por meio de algumas das complementaridades que se estabelecem entre as empresas do circuito superior. Exemplo disso é que o principal cliente da Dixie-Toga em Londrina são as lojas da cadeia de lanchonetes MacDonald's instaladas na cidade.

Os ramos de embalagens e plásticos vêm crescendo nos últimos anos e podem ser considerados indicadores da diversificação e consolidação do processo de industrialização da cidade. A presença desses ramos redefiniu a estrutura do circuito superior ligado à produção em Londrina com a incorporação de ramos industriais mais intensivos em tecnologia (BRAGUETO, 2007)

Pelo lado das atividades ligadas ao consumo a construção do Shopping Catuaí se apresenta como um evento significativo. A constituição de mega-empreendimentos, aqueles que superam a casa dos 50 mil $\mathrm{m}^{2}$ e exigem fortes disponibilidades de infraestrutura, de área e em geral são capitaneados por fundos que reúnem diversos tipos de capital (OLIVEIRA, 1996) está em sintonia com a dinâmica do período atual. A construção do Shopping Catuaí, inaugurado em 1990, envolveu 
investimentos da ordem de 55 milhões de dólares e reuniu desde capitais locais, oriundos da construção civil, a bancos e fundos de investimento (SILVA, 2006, p.120). Além disso, mobilizou o poder público, que reestruturou o sistema viário no entorno do Shopping, ampliando a acessibilidade à área de concentração dos loteamentos e condomínios fechados de alto padrão.

Desde sua inauguração o Shopping Catuaí passou por duas ampliações indicando a lucratividade desse tipo de estratégia de incorporação imobiliária em Londrina. Além do Catuaí há o Shopping Royal Plaza construído no Centro Principal da cidade e inaugurado em 1999. Apesar de contar com uma área construída menor e um número menor de lojas, também produziu impactos significativos na área em que foi implantado. Os arredores do Royal Plaza também passaram por um processo de valorização, ainda que muito mais modesto do que o verificado nos arredores do Catuaí.

A construção de mega-empreendimentos na cidade não se restringe aos shopping centers. Estão previstos investimentos do Grupo Sonae em mais um Shopping a ser construído no Centro Principal. O novo centro comercial, cuja inauguração está prevista para 2011, faz parte de um novo mega-empreendimento denominado "projeto marco zero" que deverá incluir também edifícios residenciais e comerciais.

Os novos elementos da economia urbana, tanto aqueles ligados ao consumo como os ligados à produção, revelam um maior grau de internacionalização do circuito superior em Londrina. Essa tendência está em sintonia com o processo de globalização. O circuito superior que repercute fielmente as transformações na divisão hegemônica do trabalho se torna mais complexo e menos integrado às divisões de trabalho locais. 


\section{4 - O período atual e o circuito inferior da economia urbana}

O circuito inferior em Londrina, a partir dos anos 1990, passou por um processo de reestruturação com a incorporação de novas atividades intimamente vinculadas as dinâmicas do período e à configuração do meio construído. Na raiz das novas atividades estão o desemprego e a nova configuração da pobreza no período atual.

O desemprego crônico é uma das variáveis do período atual que tem implicações importantes na dinâmica do circuito inferior londrinense. Para muitos trabalhadores o desemprego se transforma em condição quase permanente, especialmente quando a função que exerceram por longos períodos deixa de existir. Para enfrentar a desocupação e o nivelamento por baixo das remunerações oferecidas nos postos de trabalho formais, parte significativa desse contingente vai se abrigar nas atividades do circuito inferior. A partir dos anos 1990, multiplica-se na cidade o número de pessoas que trabalham como camelôs, autônomos em geral, motoboys, cabelereiros, manicures e mototaxistas ${ }^{94}$.

Embora não existam dados para indicar quantitativamente a expansão do circuito inferior, é possível claramente afirmar que houve reestruturação desse circuito em Londrina, com a incorporação de novas atividades. A reestruturação do circuito inferior em Londrina é resultante das novas configurações assumidas pelo circuito superior na cidade no período atual. A desvalorização de formas tradicionais de comércio e serviços, o rebaixamento do valor do trabalho e os novos perfis das atividades modernas em relação à quantidade e à qualificação dos trabalhadores que empregam, são produtoras de reestruturação e expansão do circuito inferior. A discussão sobre a dinâmica atual do circuito inferior londrinense é o objetivo da segunda parte do trabalho.

\footnotetext{
${ }^{94}$ Os dados dos Censos Demográficos de 1991 e 2000 mostram que, comparando o item posição na ocupação, o número de pessoas ocupadas não remuneradas cresceu 59\%, o número de pessoas que trabalhavam por conta própria cresceu $23 \%$ e número de empregados cresceu $13 \%$.
} 


\subsection{1 - Algumas considerações sobre o período atual: desemprego, pobreza e rupturas}

As condições da economia urbana no período atual favorecem a constituição de relações de produção nas quais a exploração do trabalho se intensificou em grande medida. Assim, situações como jornadas de trabalho de 12 horas diárias durante 6 dias por semana, as quais pareciam superadas ou tornadas residuais pela expansão da sociedade salarial e pelo advento do Estado do Bem Estar Social ${ }^{95}$, voltam a ocorrer com certa freqüência.

Marcio Pochmann (1999, p.15) afirma que a partir de meados dos anos 1980 houve uma quebra do "padrão sistêmico de integração social", que se difundira pelo planeta no período pós-guerra. Essa percepção vem acompanhada de argumentos que indicam claramente um sentido de perda, principalmente a perda da estabilidade e de direitos sociais. O conceito de precarização sintetiza a leitura do contexto histórico que está subjacente aos argumentos de Marcio Pochmann.

O contexto histórico da difusão do padrão sistêmico de integração social no período pós-guerra também corresponde à consolidação do Capitalismo Monopolista e à sociedade de consumo. Esse período foi analisado por muitos autores, particularmente pelos críticos da sociedade industrial, como os diversos autores da chamada "Escola de Frankfurt".

Herbert Marcuse (1979, p. 31 e 32) construiu o conceito de "homem unidimensional", para criticar justamente as conseqüências da integração do individuo às sociedades de consumo de massa. Para Marcuse (1979) o sujeito integrado à sociedade de consumo perde liberdade potencial que as condições técnicas poderiam Ihe proporcionar

\footnotetext{
${ }^{95}$ Segundo Sonia Draibe (1990, p 3) O Estado do Bem Estar Social (Welfare State) se expressa na "organização e produção de bens e serviços coletivos, na montagem de esquemas de transferências sociais; na interferência pública sobre a estrutura de oportunidades de acesso a bens e serviços públicos e privados e, finalmente, na regulação da produção e distribuição de bens e serviços sociais privados."
} 
para obter em troca uma pseudossegurança, mais próxima da morte do que a vida. A contrapartida do consumo era o conformismo.

No Brasil o padrão sistêmico de integração social (POCHMANN, 1999), assim como outras modernizações, foi importado e implantado de forma incompleta e conservadora, aprofundando as coerções do capital sobre o trabalho ${ }^{96}$, disciplinando-o por meio da formação de um gigantesco exército industrial de reserva. No Terceiro Mundo a produção do conformismo se apoiou mais na violência do que nas promessas do consumismo. Talvez essa trajetória ajude a explicar a ênfase dada ao que se perdeu, àquilo que, mesmo sem ter se completado, foi interrompido pelo projeto neoliberal dos anos 1990.

Apesar das considerações que necessariamente relativizam as eventuais qualidades e positividades do tal padrão sistêmico de integração social no contexto brasileiro, é oportuno assinalar que, durante o período de sua vigência, houve sinais de redução nos níveis de pobreza e miséria ${ }^{97}$. Essa redução resultou da combinação entre expansão do trabalho assalariado, especialmente na indústria, acelerado crescimento econômico e algumas ações elementares no âmbito do Estado do Bem Estar Social, ainda que sob o regime ditatorial.

Os limites dessa discussão são evidentes; trata-se da relação entre sobrevivência, emprego e consumo como parâmetros do conceito de pobreza urbana. Não pretendemos ir muito além dessas questões. A discussão que objetivamos gira em torno da reprodução social em seus contornos básicos, tema que, nos países subdesenvolvidos, requer atenção continuada.

\footnotetext{
${ }^{96}$ Refiro-me, sobretudo, ao período da Ditadura Militar em que modificações na legislação trabalhista, como a implantação do FGTS, aumentam a rotatividade da força de trabalho, o fundo público gerado com retiradas compulsórias dos ganhos dos assalariados financia a construção da infraestrutura urbana por meio do Sistema Financeiro da Habitação e, principalmente, a livre organização sindical e as greves são reprimidas com violência e prisões.

97 "Em um contexto de liberalização dos intercâmbios e de fortalecimento do mercado financeiro, as desigualdades entre a renda do trabalho e a do capital se acentuaram, as vezes fortemente. As desigualdades, em termos de renda do trabalho, entre trabalhadores qualificados e não qualificados também aumentaram na maioria dos países durante os últimos dez ou quinze anos. A pobreza, nos países do Terceiro Mundo, após ter recuado nas economias que passaram por um crescimento muito elevado estão voltando a crescer, mesmo que modestamente, e mesmo erradicando sua forte inflação, reaparece junto com a eclosão da crise asiática, em 1997, e a expansão do desemprego na América Latina." (SALAMA, 1999, p.21)
} 
As relações entre as rupturas e reestruturações dos anos 1990, e a dinâmica do empobrecimento tem grande importância para a análise da reestruturação dos circuitos da economia urbana. Milton Santos (2008, p.69 a 71) argumenta que os países subdesenvolvidos, entre eles - Brasil, conheceram três formas de pobreza: pobreza residual ou "incluída", pobreza marginal e a pobreza estrutural globalizada ${ }^{98}$. A primeira forma caracterizava-se por situações locais e localizadas de pobreza, inadaptadas aos processos mais gerais de mudança. Entretanto, não era algo que tivesse a condição de se generalizar, de se difundir pelo território (SANTOS, 2008).

$\mathrm{Na}$ segunda forma, que corresponderia ao contexto de vigência do padrão sistêmico de integração social, o fenômeno da pobreza era algo indesejável que se pretendia superar, ainda que por meio de medidas tecnocráticas. A pobreza era medida por meio de índices, era objeto de preocupação por parte do Estado e considerada como algo possível de ser solucionado no âmbito do desenvolvimento, da trajetória que completaria a difusão do padrão de integração social. Essa perspectiva, a da pobreza marginal, estimulava a tomada de medidas, em países subdesenvolvidos, visando estabelecer formas de luta contra a pobreza à semelhança do que acontecia em países desenvolvidos e países socialistas.

A criação de empregos formais ${ }^{99}$, isto é, vínculos de trabalho acompanhados de alguns direitos e de possibilidades de contar com cobertura previdenciária, e a manutenção das políticas macroeconômicas que lhes davam sustentação, podem ser colocadas no plano do combate às situações de miséria e, ao mesmo tempo, de uma ampla reprodução dos contingentes de pobres urbanos no Brasil. A formação do mercado urbano de trabalho a partir da década de 1930, e particularmente após os anos 1950, foi acompanhada do florescimento de

\footnotetext{
${ }^{98}$ Trataremos dessa terceira perspectiva no capítulo 4.

${ }^{99}$ Segundo Marcio Pochmann (1999, p.68) entre 1940 e 1980 a cada 10 ocupações geradas, 8 eram assalariadas, sendo 7 delas com registro em carteira.
} 
uma variada gama de atividades e ocupações no âmbito do circuito inferior da economia urbana.

O circuito inferior foi simultaneamente uma conseqüência e a possibilidade da reprodução ampliada da pobreza urbana, que se revelou bastante funcional ao processo de acumulação de capital de base industrial. Podemos dizer que essa tese foi demonstrada pela teoria dos circuitos e pela "Critica da razão dualista" de Francisco de Oliveira. Cada um a seu modo. A teoria dos circuitos procurou desvelar as relações entre a modernização e as formas encontradas pelos pobres nas cidades para melhorar sua condição material.

No período de vigência do padrão sistêmico de integração social no Brasil, entre os anos 1940 e 1990, a conjugação do processo de estruturação do mercado nacional de trabalho com a formação de um diversificado circuito inferior da economia urbana, permitiu alguns avanços em relação à questão da sobrevivência nas cidades, especialmente em relação à conquista de um cotidiano menos instável.

A situação mudou nos anos 1990, com a chegada ao poder das coalizões que implementam políticas neoliberais ${ }^{100}$. O cotidiano se tornou instável, ameaçado pelo desemprego e pelo empobrecimento. Em Londrina o projeto neoliberal provocou uma crise de grandes proporções que se manifestou em diversas frentes.

Nos anos 1990, houve um aumento significativo de ocupações irregulares de áreas urbanas: construção de abrigos precários e barracos em áreas de fundos de vale, ocupação com habitações precárias em áreas públicas e particulares. Simultaneamente, foram drasticamente reduzidos os investimentos na produção de habitações populares, após a falência do Sistema Financeiro da Habitação nos anos 1980.

\footnotetext{
${ }^{100}$ As políticas neoliberais podem ser caracterizadas por um conjunto de medidas macroeconômicas, tais como: contração da emissão de moeda, elevação da taxa de juros básicos, redução de impostos sobre as rendas mais elevadas, desregulamentação do mercado de trabalho, desregulamentação do comércio externo, desregulamentação do mercado financeiro, redução da participação do Estado na economia pelo enxugamento dos gastos sociais e privatizações de empresas estatais, entre outras.
} 
Um dos eventos mais expressivos dessa ruptura foi a constituição do assentamento urbano situado na zona sul de Londrina denominado União da Vitória. O assentamento reunia cerca de 1.400 famílias que, auxiliadas por instituições da sociedade civil, e após um processo de negociação e muita pressão por parte dos assentados sobre a Prefeitura, começou a ser regularizado em 1985.

O bairro Jardim União da Vitória ao longo do tempo se integrou totalmente ao meio construído. Apesar de contar com infraestruturas básicas (água, luz, transporte, escola) o bairro tem uma paisagem que revela grandes carências. As casas são pequenas $(40 \mathrm{~m}$, $60 \mathrm{~m}$ ) e estão localizadas em área de forte declividade. Em geral são inacabadas e misturam partes construídas em alvenaria com expansões improvisadas.

O processo de integração desse bairro e da população que ele abriga difere em muito daquele que se verificou nos bairros que se formaram a partir de conjuntos habitacionais na zona norte. Apesar de haver enfrentado situações muito duras de carência e dificuldade para obter infraestrutura completa e equipamentos urbanos (ALVES, 1991), os bairros da zona norte revelam em sua paisagem um contexto de integração à cidade menos excludente e precário.

A ruptura que o assentamento União da Vitória representa em relação a política habitacional e ao conjunto de políticas públicas dos anos 1970 e 1980, se acentuou ao longo dos anos 1990. No final dos anos 1980 existiam em Londrina 15 ocupações urbanas irregulares. Ao longo dos anos 1990 surgiram mais de 40 ocupações irregulares, abrangendo cerca de 50 mil pessoas, ou seja, $10 \%$ da população urbana (OLIVEIRA e FRESCA, 2005, p. 119).

De forma semelhante ao que ocorrera com a política habitacional as opções feitas no âmbito do projeto neoliberal penalizaram severamente os empregos. Segundo Pochmann (2001, p.102) nos anos 1990 o desemprego deixou de ser um problema que atingia algumas pessoas e passou a ser um fenômeno de massa, generalizando-se pela 
PEA e se alastrando para todas as regiões do país. Entre 1989 e 1999 o desemprego cresceu $280 \%$.

Ao longo desse processo de expansão do desemprego aumentam as exigências que incidem sobre os que se candidatam às vagas abertas. O novo analfabetismo imposto pelo sistema técnico informacional limitou as possibilidades de milhares de trabalhadores, inclusive daqueles que possuíam alguma escolaridade.

Em Londrina as indústrias alimentícias e de vestuário são as que detêm o maior número de estabelecimentos e o maior volume de empregos, no contexto da indústria de transformação. Esses setores foram bastante atingidos pela abertura indiscriminada do mercado interno às importações e contribuíram para que, no final dos anos 1990 o desemprego na cidade se tornasse um problema generalizado. As novas empresas que a política de atração de investimentos da Prefeitura trouxe para a cidade são empresas que, do ponto de vista da contratação de força de trabalho, não foram suficientes para sequer minimizar o problema do desemprego.

As transformações do circuito superior se deram no sentido de substituir empresas mais intensivas em trabalho por empresas que operam a partir de uma composição orgânica de capital mais elevada. As novas empresas, como a Atlas Schindler, têm processos automatizados de produção que requerem um número limitado de trabalhadores qualificados. Essa característica se repete em relação a Dixie-Toga e à Milenia. Os novos atores do circuito superior ligado à produção absorvem menos trabalho vivo do que aqueles que compunham o circuito superior nos anos 1970 e $1980^{101}$.

Outra face do problema do desemprego é que ele pressiona para baixo as remunerações ao aumentar a competição pelos postos de trabalho. Essa conjuntura bastante desfavorável aos trabalhadores é

\footnotetext{
${ }^{101} \mathrm{O}$ fechamento da unidade industrial da Coinbra e a transferência das atividades para Ponta Grossa causou o desemprego de centenas de trabalhadores na cidade. A unidade dessa agroindústria que fora comprada da Anderson Clayton empregava mais gente do que os novos estabelecimentos.
} 
agravada pela intensificação da competição que a abertura e desregulamentação do mercado produziu.

A competição mais intensa afetou as pequenas empresas do circuito superior marginal em Londrina. Em geral são empresas que realizam operações intermediárias de processos produtivos de empresas maiores. Um exemplo são as facções da indústria de vestuário e pequenas confecções que produzem roupas e também realizam tarefas específicas para grandes indústrias.

Para não perder os grandes clientes essas empresas são pressionadas a reduzir suas margens e achatam os salários dos funcionários ou passam a atuar na informalidade. Essa tendência incide sobre uma situação que já não era muito confortável; em geral, as pequenas e microempresas pagam salários menores do que as médias e grandes.

Segundo as estatísticas do IBGE, é substancial a diferença
observada entre as remunerações nas grandes e nas pequenas
empresas. Este Instituto verificou que, nas empresas com até 10
empregados, a remuneração média é de 3,25 salários mínimos,
enquanto que nos estabelecimentos com 11 pessoas, ou mais,
esta média sobe para 5,1 SM. Ou seja, os salários ou
remunerações das pequenas empresas são, em média, 60\%
inferiores aos dos outros estabelecimentos. (MALAGUTI, 2000,
p.82)

A competitividade, palavra de ordem do período atual, por mecanismos diversos, acaba por incidir sobre as remunerações dos trabalhadores das pequenas empresas, uma das principais fontes de emprego em Londrina. A associação entre desemprego e baixas remunerações é determinante para o processo atual de produção da pobreza.

Em síntese a reestruturação do circuito inferior em Londrina é uma decorrência das variáveis do período atual, dentre elas, especialmente o desemprego, as baixas remunerações e a produção estrutural da pobreza. Tais variáveis atuam de forma combinada com as transformações do circuito superior da economia urbana londrinense. 


\section{PARTE II}

\section{A REESTRUTURAÇÃO DOS CIRCUITOS}




\section{CAPÍTULO 4}

\section{A racionalidade do circuito inferior no período atual}

\section{1 - Racionalidade hegemônica e circuito inferior}

A teoria dos circuitos da economia urbana requer que se compreenda a cidade a partir de uma visão totalizadora.

A cidade é uma totalidade, feita de coisas e pessoas, de objetos e
relações, de formas e ações, num movimento desigual e
combinado, numa dinâmica de cooperação e conflito. [...] Se a
consideração do meio construído como uma totalidade é um
partido de método, é preciso olhar, ao mesmo tempo, os sistemas
de ações ou, em outros termos, ver a cidade como um conjunto,
solidário e contraditório de divisões de trabalho. Suas funções mais
modernas, aquelas que norteiam sua inserção na atual divisão
internacional do trabalho hegemônica, não podem ser confundidas
com a cidade ela própria. [...] A cidade não é apenas o reino das
grandes corporações e dos grandes bancos, o reino do circuito
superior (SANTOS, 1975), mas também o lugar do trabalho não-
especializado, das produções e serviços banais, das ações ligadas
aos consumos populares - aquelas necessidades criadas pelo
nosso tempo mas cuja resposta não é dada pela economia
hegemônica. (SILVEIRA, 2004, p.60)

As relações de subordinação e interdependência entre os circuitos possibilitam a análise do modo como, em suas diversas escalas, convivem e interagem na cidade a divisão de trabalho hegemônica e as divisões de trabalho não-hegemônicas.

No período atual a divisão do trabalho hegemônica ligada ao circuito superior realiza, por meio de verticalidades ${ }^{102}$, a integração da cidade a um espaço de fluxos constituído por redes (SANTOS, 2008, p.106). A divisão do trabalho hegemônica apresenta características específicas em face da dinâmica do período atual, especialmente as determinações emanadas da economia global. Milton Santos (2008) afirma que a divisão do trabalho progressivamente deixou de ser

\footnotetext{
102 “As verticalidades podem ser definidas, num território, como um conjunto de pontos formando um espaço de fluxos. [...] O sistema de produção que se serve desse espaço de fluxos é constituído por redes - um sistema reticular -, exigente de fluidez e sequioso de velocidade. São os atores do tempo rápido, que plenamente participam do processo, enquanto os demais raramente tiram todo proveito da fluidez" (SANTOS, 2008, p.106)
} 
produzida de forma relativamente espontânea e passou a ser objeto de intencionalidades guiadas por parâmetros científicos e que "por isso a consideramos uma divisão do trabalho administrada - e é movida por um mecanismo que traz consigo a produção de dívidas sociais e disseminação da pobreza numa escala global" (SANTOS, 2008, p.73).

A relação entre a divisão do trabalho hegemônica e a disseminação da pobreza passa pelo desemprego crônico ${ }^{103}$. Desse modo, pobreza e desemprego são produtos da racionalidade hegemônica manifestada nos lugares.

O desemprego aberto mundial cresceu de forma acelerada nos anos 1990, abarcando parcelas cada vez maiores da população economicamente ativa em diversos países ${ }^{104}$. Essa nova onda de desemprego resulta das transformações na divisão internacional do trabalho decorrentes da forma desigual e combinada que caracterizou a difusão das novas tecnologias de informação e comunicação e a reformulação dos processos globais de acumulação de capital coordenado por grandes corporações globais, incluindo o crescimento da mobilidade territorial dos investimentos e a constituição de empresas em rede (POCHMANN, 2001, p.29 e 30)

No Brasil, assim como em outros países da América Latina, o aumento do desemprego se apresenta com gravidade ainda maior, uma vez que, incide sobre um contexto social em que persistem formas tradicionais de superexploração do trabalho, expressas no subemprego e nos baixos rendimentos da população ocupada, as quais convivem com sistemas de proteção social incompletos e desiguais.

Segundo o Departamento Intersindical de Estatística e Estudos Socioeconômicos (DIEESE), que realiza a pesquisa mensal de emprego e desemprego (PESQUISA EMPREGO E DESEMPREGO, 1984-), o

\footnotetext{
${ }^{103}$ Vamos nos deter mais sobre essa relação no capitulo 4.

${ }^{104}$ Em 1996 o Relatório da OCDE sobre o desemprego estimava que o tamanho da PEA mundial fosse de 2,5 bilhões de trabalhadores dos quais 35\% estavam em situação de desemprego e/ou subempregados. Nos países membros da OCDE havia 34 milhões de desempregados e a taxa de desemprego tendia a se estabilizar em torno de $10 \%$. (POCHMANN, 1999, p.37 e 38).
} 
desemprego total ${ }^{105}$ cresceu de forma acentuada no Brasil a partir de meados dos anos $1990^{106}$ e, nos últimos anos, mostrou tendência de queda. No entanto, até 2008, ainda permanecia em patamares superiores a $10 \%$ da PEA.

\section{Gráfico 13}

Brasil: índice médio de desemprego total em seis Regiões Metropolitanas, 1998 a 2008.

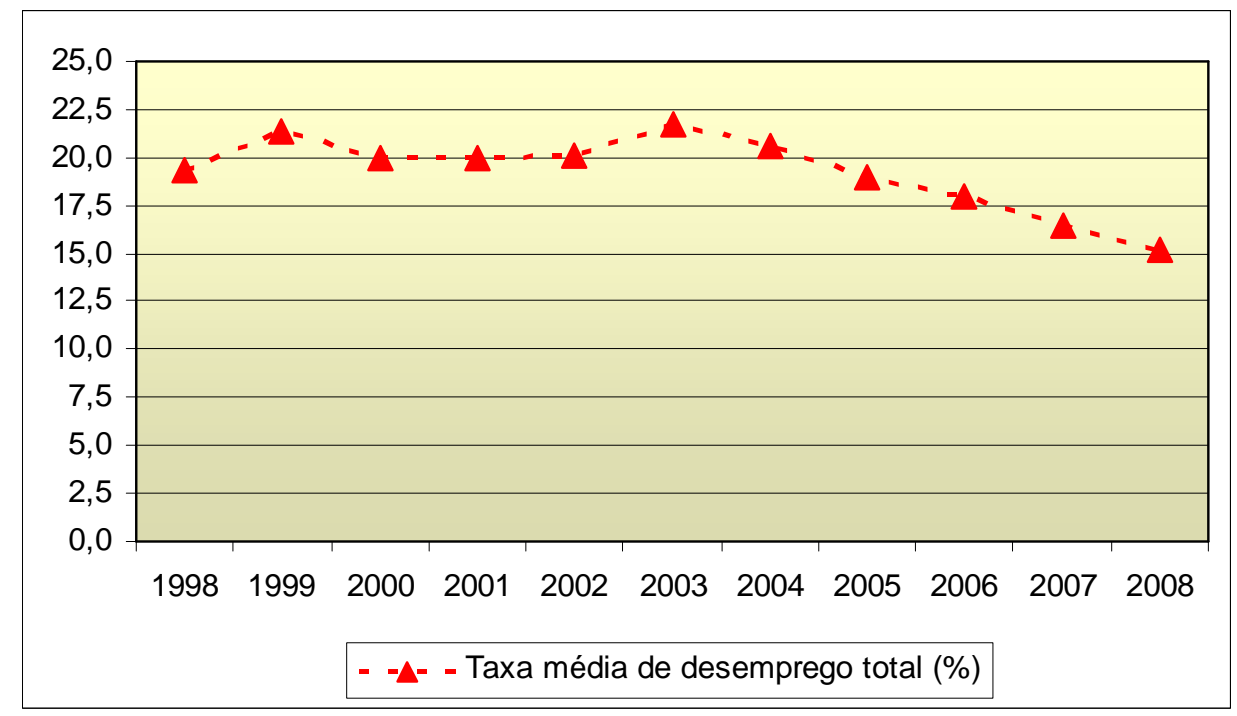

Fonte: DIEESE, Pesquisa Emprego e Desemprego.

As repercussões desse novo contexto amplamente desfavorável ao trabalho se fizeram sentir, por exemplo, no aumento da competição entre os trabalhadores, na redução da atividade sindical e na necessidade de readequação das habilidades dos trabalhadores para que acompanhem as constantes mudanças nos processos de produção e também na esfera da circulação.

Em Londrina, trabalhadores ligados ao setor de transportes que trabalhavam na classificação, embalagem e armazenamento de produtos em grandes transportadoras foram substituídos por sistemas automatizados de classificação e armazenamento a partir do desenvolvimento de softwares específicos e de novas formas de

\footnotetext{
105 A metodologia empregada pelo DIEESE na PED mede o chamado desemprego total, isto é, o desemprego aberto e também o desemprego oculto, que inclui situações de trabalho esporádicas (bicos) e não remuneradas, entre outras.

106 "Segundo dados de 1999, o desemprego aumenta em todo país. Na Região Metropolitana de São Paulo atingia 1,726 milhão de pessoas, isto é, 19,9\% da sua população economicamente ativa (eram 12,2\% em 1985, um total de 819 mil pessoas)" (SANTOS e SILVEIRA, 2001, p.219)
} 
organização dos armazéns ${ }^{107}$. Após passar anos executando uma mesma função, esses trabalhadores têm agora de enfrentar um mercado de trabalho local no qual, para obter salários semelhantes aos que tinham antes, precisariam atender aos requisitos de novas ocupações como as de operadores de telemarketing e outras funções ligadas às tecnologias da informação e comunicação.

Essa situação afeta, principalmente, trabalhadores que não são especializados, cuja escolaridade atinge no máximo o ensino médio. A rapidez com que as novas habilidades aprendidas, especialmente conhecimentos básicos de informática e de processos produtivos específicos, se tornam descartáveis ou insuficientes para concorrer a um novo posto de trabalho aumenta a vulnerabilidade e a instabilidade que permeia o cotidiano de quem busca um novo emprego.

Entre as resultantes dessa dinâmica está a expansão do excedente estrutural de trabalhadores que, ao longo do tempo, adquiriram certa especialização em função de sua inserção no mercado de trabalho e que passaram a condição de desempregados por conta das sucessivas conjunturas desfavoráveis. A saída para muitos desses trabalhadores descartados do mercado formal de trabalho é se estabelecer em uma atividade por conta própria.

Ao mesmo tempo, no contexto da divisão de trabalho hegemônica, surgem novas profissões, a exemplo dos operadores de telemarketing e dos profissionais de tecnologias da informação, ligadas aos novos processos de produção e circulação apoiados em novos objetos técnicos (SANTOS e SILVEIRA, 2001, p.220). A presença desses contingentes de trabalhadores especializados, ainda que não sejam tão numerosos quanto os trabalhadores sem especialização, amplia as atividades ligadas ao consumo e a circulação de mercadorias e informações e a fragmentação do meio construído.

Por um lado a ampliação do consumo e da circulação de informações associada à fragmentação do meio construído possibilita a

\footnotetext{
${ }^{107}$ Conforme entrevista com o Sr. S. mototaxista da Central Rota 99.
} 
coexistência de diferentes divisões de trabalho. Por outro, cria as condições para a subordinação das atividades do circuito inferior aos ritmos e demandas das atividades hegemônicas.

Um aspecto da diferença entre as divisões de trabalho está na formação de "uma especialização das atividades por cima e uma especialização de atividades por baixo" (SANTOS, 2004, p.324).

A especialização das atividades por cima, no âmbito do circuito superior, atende a objetivos e interesses distantes, muitas vezes determinados a partir do exterior e tem como premissa básica a competitividade e a lucratividade máximas, enquanto a especialização das atividades por baixo tem raízes locais e, em geral preconiza a manutenção das condições de vida alcançadas. As especializações das atividades "por cima" se dão, portanto, em sintonia com as verticalidades e com a reestruturação do circuito superior. As especializações das atividades "por baixo" dialogam com as horizontalidades.

O par dialético das verticalidades são as horizontalidades ${ }^{108}$ e sua ligação com o cotidiano. As divisões do trabalho criadas a partir das necessidades dos que sofrem as conseqüências da racionalidade hegemônica, especialmente o desemprego, mantêm com as horizontalidades um vínculo genético.

\begin{abstract}
Nas grandes cidades, sobretudo do Terceiro Mundo, a precariedade da existência de uma parcela importante (às vezes a maioria) da população não exclui a produção de necessidades, calcadas no consumo das classes mais abastadas. Como resposta, uma divisão de trabalho imitativa, talvez caricatural, encontra as razões para se instalar e se reproduzir. [...]

Essas metamorfoses do trabalho dos pobres nas grandes cidades cria o que, em um outro lugar (Santos, 1991), denominamos de "flexibilidade tropical". Há uma variedade infinita de ofícios, uma multiplicidade de combinações em movimento permanente, dotadas de grande capacidade de adaptação, e sustentadas no seu próprio meio geográfico, este sendo tomado como uma formaconteúdo, um híbrido de materialidade e relações sociais. (SANTOS, 2004, p.324)
\end{abstract}

\footnotetext{
108 “As horizontalidades são zonas de contigüidade que formam extensões contínuas. [...] O espaço banal seria o espaço de todos: empresas, instituições, pessoas; o espaço das vivências. Esse espaço banal, essa extensão continuada, em que os atores são considerados na sua contigüidade, são espaços que sustentam e explicam um conjunto de produções localizadas, interdependentes, dentro de uma área cujas características constituem, também, um fator de produção.” (SANTOS, 2008, p.109)
} 
A racionalidade hegemônica não é, de fato, a única racionalidade presente no meio urbano, mas é a que os atores hegemônicos pretendem impor como a única válida, como o único critério de avaliação da cidade e do urbano que ela abriga. Suas exigências de fluidez e velocidade, intimamente associadas às verticalidades, aos objetos geográficos que as sustentam e às normas que autorizam usos hegemônicos da cidade, constituem parâmetros de um discurso que, unilateralmente, desqualifica as especializações inerentes às divisões do trabalho das quais participam as atividades do circuito inferior.

Rotuladas como irracionais, perigosas e indesejáveis as especializações geradas no âmbito da flexibilidade tropical e do circuito inferior são hostilizadas: vendedores ambulantes que carregam consigo algumas cópias não autorizadas, consideradas ilegais e por vezes mal feitas de filmes e músicas são quase que automaticamente considerados extensão do crime organizado e assim estigmatizados como "ajudantes de bandidos", o uso de parte do fundo público na criação de camelódromos é desperdício de dinheiro e motiva ações na justiça, o reconhecimento da profissão de mototaxista é taxada de imediato como "carnificina" independentemente do tamanho da cidade e das condições e normas para prestação desse serviço.

A ideologia que permeia esses discursos age como de costume: propõe meias verdades como se inteiras fossem, afasta a gênese e a leitura estrutural das condições políticas, sociais e econômicas que produzem esses trabalhadores como excedentes aos sistemas de produção hegemônicos e que simultaneamente os absorve, conferindoIhes funcionalidade como informais, ilegais e, sobretudo, como trabalho vivo e barato, por que expurgado de direitos sociais.

As horizontalidades, pois, além das racionalidades típicas das verticalidades que as atravessam, admitem a presença de outras racionalidades (chamadas de irracionalidades pelos que desejam ver como única a racionalidade hegemônica). Na verdade, são contra-racionalidades, isto é, formas de convivência e de regulação criadas a partir do território e que se mantêm nesse território a despeito da vontade unificação e homogeneização, características 
da racionalidade hegemônica típica das verticalidades. (SANTOS, 2008, p.110)

A situação é complexa. Há atritos, conflitos mais ou menos intensos e também formas de cooperação entre a racionalidade hegemônica e as contra-racionalidades, entre as especializações por "cima e por baixo". A dinâmica do período atual desautoriza concepções dualistas, que sempre teimam em reaparecer, a exemplo das que subjazem às interpretações reducionistas que empregam de forma rígida conceitos como setor informal e informalidade. Tampouco cabe falar do famoso "inchaço" do terciário, como anomalia que se manifesta em relação a processos normais de desenvolvimento, nos quais certa noção de equilíbrio é sempre retomada.

A crítica a esse tipo de interpretação foi elaborada por trabalhos seminais como a "Crítica à Razão Dualista" de Francisco de Oliveira. Analisando o processo de desenvolvimento brasileiro entre 1930 e 1970 o autor apontava que a expansão do terciário, especialmente o terciário banal, constituía-se em uma espécie acumulação primitiva apoiada no intenso processo de migração rural-urbano.

No processo de sua expansão, sem contar com magnitudes prévias de acumulação capitalística, o crescimento industrial forçosamente teria que centrar sobre a empresa industrial toda a virtualidade da acumulação propriamente capitalista; sem embargo, ela não poderia dar-se sem apoio de serviços propriamente urbanos, diferenciados e desligados da unidade fabril propriamente dita, as chamadas "economias externas". Era tal a carência desses serviços, que a primeira onda de industrialização assistiu à tentativa de autarquização das unidades fabris, processo que logo seria substituído por uma divisão de trabalho para além dos muros da fábrica. Logo em seguida, com a continuidade da expansão industrial, esta vai compatibilizar-se com a ausência de acumulação capitalista prévia, que financiasse a implantação dos serviços, lançando mão dos recursos de mão de obra, reproduzindo nas cidades um tipo de crescimento horizontal, extensivo, de baixíssimos coeficientes de capitalização, em que a função de produção sustenta-se basicamente na abundancia de mão-de-obra. (OLIVEIRA, 2003, p.55)

O autor enfatiza ainda que houve a criação de uma grande gama de formas de produção artesanais, como oficinas de reparação de todos os tipos e também de serviços de consumo individual cuja participação cresceu no emprego total do país, a partir da década de 
1940. Seu argumento principal é o de que esses serviços do terciário banal são adequados e funcionais à acumulação capitalista.

Não é estranha a simbiose entre a "moderna" agricultura de frutas
e hortaliças e outros produtos de granja com o comércio
ambulante? Qual é o volume de comércio de certos produtos
industrializados - o grifo é proposital - tais como lâminas de
barbear, pentes, produtos de limpeza, instrumentos de corte, e um
sem-número de pequenos objetos, que é realizado pelo comércio
ambulante das ruas centrais de nossas cidades? Qual é a relação
que existe entre o aumento da frota de veículos particulares em
circulação e os serviços de lavagem de automóveis realizados
braçalmente? Existe alguma incompatibilidade entre o volume
crescente de produção automobilística e a multiplicação de
pequenas oficinas destina à re-produção dos veículos? Como
explicar que todos os tipos de serviços de consumo pessoal
cresçam mais exatamente quando a indústria recupera seu
dinamismo na criação de empregos e quando todo um processo se
cristaliza - conforme os resultados do Censo Demográfico de 1970
- numa distribuição de renda mais desigual? Esses tipos de
serviços, longe de serem excrescência e apenas depósito do
"exército industrial de reserva", são adequados para o processo de
acumulação global e da expansão capitalista e, por seu lado,
reforçam a tendência à concentração de renda. (OLIVEIRA, 2003,
p. 58)

A teoria dos circuitos apresenta conclusões semelhantes, no entanto sua perspectiva em relação à cidade é mais ampla, por que voltada para a compreensão da cidade como uma totalidade. O circuito inferior, por exemplo, não se resume ao terciário, incluindo também atividades de fabricação (SANTOS, 1979). Na teoria dos circuitos a intenção fundamental é revelar como, na economia urbana tanto as atividades intensivas em capital, ditas modernas, quanto as atividades em que o trabalho é abundante e o capital escasso, encontram seu lugar. Dessa forma, a teoria dos circuitos pôde elucidar como, por meio do circuito inferior, muitos migrantes recém-chegados às metrópoles, encontraram condições de sobreviver e até mesmo obter alguma prosperidade.

Contudo, há outro ponto em que a funcionalidade do terciário banal mudou em relação aos anos 1970, trazendo novos desafios para as pesquisas sobre a cidade. Já não se trata de gerar economias externas inexistentes, que supririam as lacunas inerentes a uma acumulação de capital centrada na indústria e profundamente desigual em 
suas componentes setoriais e regionais. A situação atual desafia as teorias sobre a cidade a refletir e analisar os modos como, se renovam as formas de produção pobreza.

Milton Santos, referindo-se ao período atual, afirma que a pobreza atual difere daquela dos anos 1970 e a denomina de "pobreza estrutural globalizada" (SANTOS, 2008, p.73). Essa atualização da produção da pobreza ocorre em conjunção com a expansão do meio técnico-cientifico-informacional, com a intensificação dos consumos e da circulação.

Analisando a conjuntura própria das cidades do Terceiro Mundo nos anos 1970, Milton Santos apresentava uma dada caracterização dos pobres ligados ao circuito inferior.

Os pobres, na visão de nosso estudo, são aqueles que não têm acesso, de modo regular, aos bens de consumo corrente considerados como mínimo indispensável numa certa sociedade. Muito raramente têm acesso ao crédito institucional e representam o essencial da clientela dos pequenos estabelecimentos comerciais ou artesanais, que oferecem crédito pessoal a taxas usurárias. Trata-se em geral dos não empregados e dos subempregados, mas também dos assalariados que recebem muito pouco (SANTOS, 1979, p.38).

É possível indagar tanto sobre a permanência como sobre as transformações dessas características. O acesso a certos bens de consumo atingem, atualmente, também os mais pobres, por meio da forte expansão do crédito. No lado das permanências, notamos que taxas usurárias nos empréstimos pessoais continuam a existir, apenas não são mais apanágio de comerciantes locais ou agiotas, e sim de grandes corporações financeiras.

Outra transformação essencial está no reforço e intensificação da instabilidade no emprego. Para além do desemprego crescente, a possibilidade de permanecer em um mesmo emprego por períodos mais longos é menor hoje do foi que nos anos 1970 (POCHMANN, 2001). Assim o cotidiano se torna mais ameaçado e instável. 
O empobrecimento relativo no período atual está ligado ao hiperconsumo ${ }^{109}$ que se sustenta nos processos de: financeirização (expansão do crédito e muito mais), de redefinição das relações entre produção e consumo e de criação de mecanismos e necessidades ligadas à diferenciação social que têm, na posse e nos modos de usar certos bens e serviços, os seus corolários.

Participa também do empobrecimento relativo e da desvalorização do trabalho e das atividades não-modernas a perda de capacidades para, por exemplo, ter acesso a ocupações (não apenas empregos) cercadas de prestígio e dotadas de melhor remuneração.

Impõe-se a nós questão de se, em face das características do período atual, a teoria dos circuitos, especialmente o conceito de circuito inferior, oferece possibilidades realmente heurísticas de interpretação da dinâmica de atualização da pobreza urbana.

Oferecer alguns elementos que, a partir de uma analise teórica e empírica centrada no circuito inferior de Londrina, permitam construir uma resposta positiva a essa questão é a tarefa que nos colocamos. Analisamos a seguir a estruturação e o funcionamento de algumas atividades do circuito inferior que se desenvolveram a partir do final dos anos 1990, quando o desemprego e o empobrecimento relativo moveram milhares de trabalhadores a constituir novas inserções na divisão social do trabalho.

\footnotetext{
109 Essa ligação entre empobrecimento e hiperconsumo (LIPOVETSKY, 2007) não se faz apenas pelo endividamento das múltiplas prestações e saldos não quitados dos cartões de crédito, mas se refere também às formas de participação social mediadas por redes sociais que exigem a posse de equipamentos e serviços que não estão acessíveis à grande maioria, como internet móvel, acesso em banda larga entre outros. Além disso, o consumo é uma arena em que as questões simbólicas, prestígio e inserção social, não podem ser esquecidas.
} 


\section{2 - A caracterização do Camelódromo de Londrina}

O Camelódromo de Londrina reúne aproximadamente 260 pequenos estabelecimentos comerciais. Predominam o comércio varejista de artigos de vestuário e acessórios, com $25 \%$ dos estabelecimentos, e o comércio varejista de discos, CD, DVD e fitas com $21 \%$ dos estabelecimentos.

Inaugurado em janeiro de 2003, o Camelódromo de Londrina está situado na área central da cidade, na esquina das ruas Sergipe e Mato Grosso. Os proprietários dos estabelecimentos estão diretamente envolvidos na atividade diária e, além deles, em $44 \%$ dos estabelecimentos trabalham mais uma pessoa e em $29 \%$ dos estabelecimentos há dois ou mais funcionários. Dessa forma, em cada dez estabelecimentos, sete têm no mínimo um funcionário trabalhando. Contando também o pessoal administrativo, de segurança e limpeza estimamos que o Camelódromo de Londrina seja responsável pela geração de empregos diretos, ocupação diária e renda para mais de 800 pessoas.

Figura 3

Camelódromo de Londrina, 2006

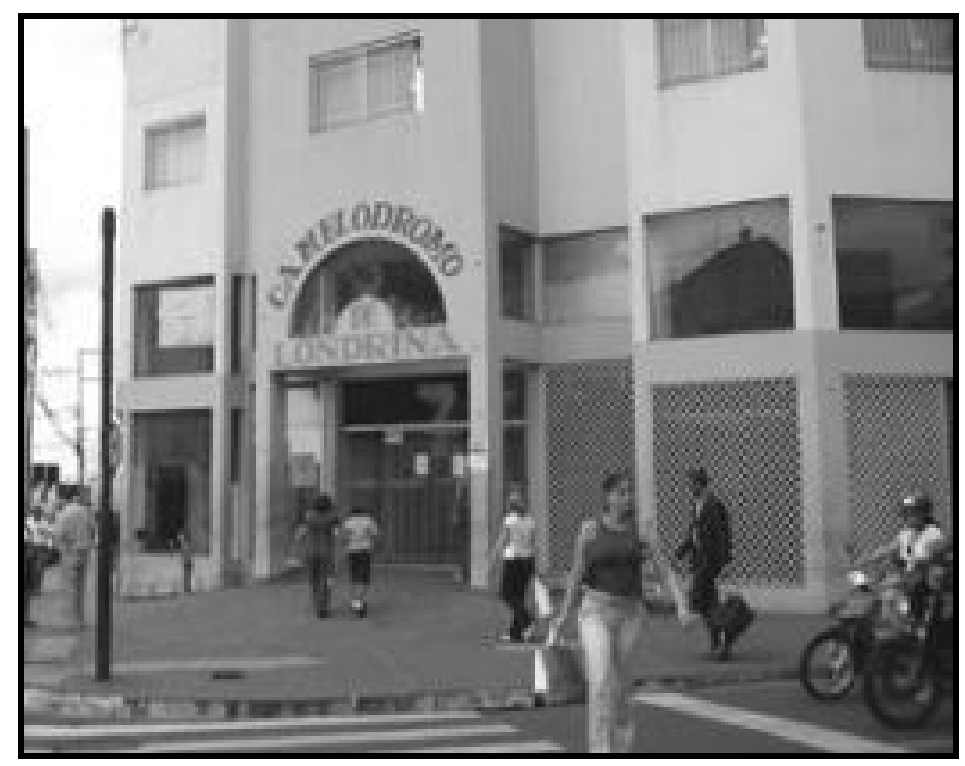

Fonte: Londrix, disponível em $<<$ http://www.londrix.com/noticias.php?id=18297>> Acesso em 15 de julho de 2008. 
Os estabelecimentos do Camelódromo de Londrina utilizam diversos equipamentos em suas operações cotidianas. Os dados do trabalho de campo ${ }^{110}$ nos permitiram constatar que parte dos estabelecimentos do Camelódromo são usuários de equipamentos e serviços modernos. O telefone fixo está presente em $68 \%$ dos estabelecimentos; no entanto, poucos informaram utilizar o telefone em suas vendas, apenas 8 estabelecimentos, o equivalente a $10 \%$ dos entrevistados.

Mais da metade dos estabelecimentos, $52 \%$, dispõem de máquinas de cartão de débito das bandeiras Visa e Master, permitindo aos clientes o uso de cartões bancários nos pagamentos. A presença de cartões de crédito obedece exatamente à mesma distribuição. Os mesmos estabelecimentos que disponibilizam para os clientes o uso de cartão de débito, também o fazem com os cartões de crédito e utilizam os mesmos equipamentos para isso. Também aceitam cartões de crédito tanto pela bandeira Visa quanto pela bandeira Master.

O uso do computador é pouco freqüente. Em $85 \%$ dos estabelecimentos não há computador. Dentre os 12 estabelecimentos que possuem computador estão os que vendem e recondicionam celulares e produtos eletrônicos. São esses estabelecimentos que fazem uso mais freqüente desse equipamento.

Também há uma loja que vende camisetas estampadas com motivos ligados ao Rock e a Cultura Pop que faz uso do computador nas vendas de seus produtos, principalmente para divulgá-los, obter informações atualizadas e atender as solicitações dos clientes.

O uso da Internet segue a mesma distribuição dos computadores, isto é, são os mesmos estabelecimentos que utilizam computadores e que também utilizam a Internet. Apenas $10 \%$ dos estabelecimentos possuíam todos os equipamentos: máquinas para cartão de débito e crédito, computador e telefone fixo.

\footnotetext{
${ }^{110}$ Trabalho de campo realizado entre 2007 e 2008. Conforme indicamos na introdução, por meio desse trabalho, colhemos informações nas quais nos baseamos para confeccionar mapas, tabelas, etc., bem como entrevistas e relatos. Nesta tese, será indicado como Trabalho de campo e o ano base dos dados tabulados.
} 
Os estabelecimentos do Camelódromo de Londrina recebem a maior parte dos pagamentos em dinheiro e a vista. A venda com uso de cheques pré-datados ocorre principalmente nos estabelecimentos que vendem produtos eletrônicos, suprimentos para informática e artigos de vestuário (bolsas e roupas), mas não é freqüente.

O aprofundamento da unicidade técnica e a intensa monetarização da vida cotidiana viabilizada pelas várias formas que o dinheiro assume são processos que estão presentes nas atividades do circuito inferior. Esses elementos participam da reestruturação e atualização do circuito inferior em face das características do período atual. No entanto, é importante destacarmos que as características fundamentais das atividades que permitem considerá-las como parte do circuito inferior não são alteradas. Os estabelecimentos do Camelódromo ainda atendem a um público composto de assalariados que ganham pouco, apresentam uma organização burocrática muito incipiente, utilizam trabalho familiar, são dependentes das dinâmicas do circuito superior, tanto pelo lado da aquisição das mercadorias, quanto pelo lado das vendas, entre outras características. 


\subsection{1 - A gênese do Camelódromo de Londrina}

Inicialmente seus ocupantes eram provenientes de dois locais distintos que se constituíram a partir de meados dos anos 1990 e ao longo da primeira década do século XXI, período em que se intensificaram os conflitos entre camelôs, prefeitura e entidades da sociedade civil em Londrina.

O primeiro local foi o antigo Camelódromo, improvisado em instalações precárias na calçada da Avenida Leste-Oeste, próximo ao Museu padre Carlos Weiss (museu histórico de Londrina) de onde vieram 94 camelôs para o atual Camelódromo.

Figuras 4 e 5

Primeiro Camelódromo de Londrina, 1997

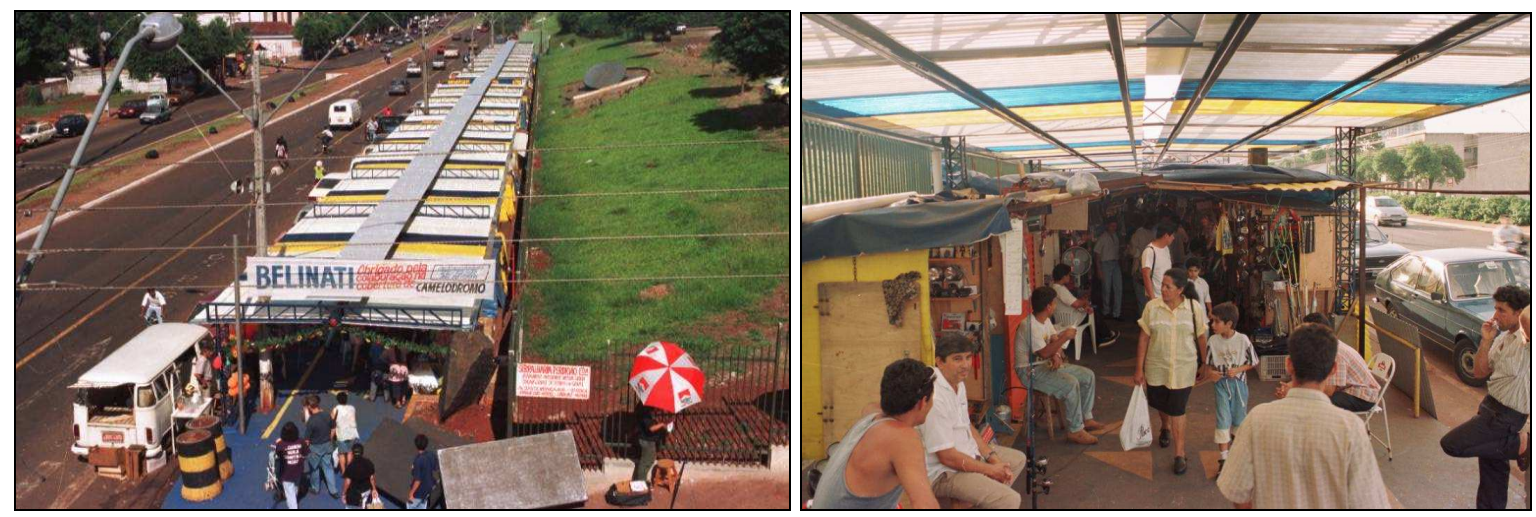

Fonte: Arquivo Folha de Londrina.

O primeiro Camelódromo, situado na Avenida Leste-Oeste começou como uma longa fileira formada por cerca de noventa barracas, cada uma medindo aproximadamente 1,5 metro de largura. A construção desse ajuntamento de camelôs começou no final de 1995, durante a administração do Prefeito Luiz Eduardo Cheida. A precariedade dessa primeira instalação ficava patente em dias de chuva e vento nos quais a atividade ficava praticamente paralisada e algumas mercadorias estragavam.

Como condição para manter a interlocução com a Prefeitura, os trabalhadores do Camelódromo tiveram que abrir micro empresas transformando-se em pessoas jurídicas, exigência posta pelo executivo municipal para ocupar um espaço no Camelódromo. Constituíram também 
a Associação do Camelódromo de Londrina (ACAL). Essa Associação passou a representar os camelôs na reivindicação de melhorias para o Camelódromo, que aos poucos foram sendo implantadas. Em dezembro de 1997, dois anos após o início das atividades no Camelódromo da Avenida Leste-Oeste, o local foi reformado e uma cobertura metálica passou a proteger todo o conjunto das intempéries. As barracas foram redistribuídas, formando duas fileiras, uma de frente para a outra, de modo a criar uma espécie de galeria. O custo das obras, cerca de $R \$ 20$ mil na época, foi repassado aos camelôs, que pagaram parcelas de $R \$$ 200,00 (BARONI,1997).

Essa forma de remediar "o problema dos camelôs" não foi suficiente para conter o avanço do comércio ambulante na cidade. Em paralelo com o crescimento acelerado do número de trabalhadores desempregados crescia também o número de vendedores ambulantes que se abasteciam com produtos obtidos nas cidades paraguaias de Guairá e Ciudad del Este.

Também as transformações em Foz do Iguaçu e Ciudad del Este, a partir do final dos anos 1980, com a passagem do comércio ligado ao turismo de compras para o comércio praticado, em escala crescente, pelos chamados sacoleiros (PERIS e LUGNANI, 2003, p.94) contribuíram para o crescimento acelerado do número de camelôs ${ }^{111}$.

Desde o início dos anos 1990, o agravamento das crises política e econômica resultantes do turbulento período em que o país foi submetido ao (des)governo do presidente Collor de Melo fez com que o problema do desemprego, já grave a partir de meados dos anos 1980, se tornasse crônico. Além das transformações técnicas e organizacionais

\footnotetext{
${ }^{111}$ Até os anos 1980 Ciudad del Este era freqüentada majoritariamente por pessoas que faziam turismo em Foz do Iguaçu e que complementavam seus passeios com compras na cidade do país vizinho. O término das obras de Itaipu criou um enorme desemprego na região. Ao mesmo tempo, a convergência entre o aparecimento de novos produtos eletrônicos como o videocassete, aparelhos de som, walkman, e mais tarde dos equipamentos digitais e de informática, entre outros, e a conjuntura nacional de grande inflação, valorização do dólar e desemprego favoreceram o início do chamado comércio de sacoleiros. $\mathrm{Na}$ região, os desempregados das obras da hidrelétrica passaram a atuar como laranjas, aqueles que realizam o transporte das mercadorias adquiridas pelos sacoleiros, que, por sua vez, são as pessoas de outras cidades e estados que vão a Foz e Ciudad del Este para comprar diversos tipos de produtos para revende-los em seus locais de origem.
} 
pelas quais passavam as empresas, especialmente as indústrias, a desorganização da produção promovida pela abertura indiscriminada da economia nacional às importações e o confisco das poupanças inerentes ao chamado Plano Collor, contribuíram para o agravamento do desemprego em todo país e para a multiplicação de pessoas envolvidas com o comércio ambulante e outras atividades ditas "informais".

No Paraná, no final dos anos 1990, estimava-se que havia mais de 900 mil pessoas trabalhando por conta própria, acompanhando o processo de empobrecimento concomitante ao de desmontagem do mercado de trabalho formal.

\footnotetext{
PR tem 900 mil no trabalho informal Pesquisas feitas pela Fundação Getúlio Vargas mostram que quanto menor a renda domiciliar, maior é a taxa de informalidade

Para o economista e pesquisador da Fundação Getúlio Vargas (FGV), Marcelo Cortes Neri, o mercado de trabalho informal e a pobreza caminham juntos. Ele apresentou ontem dados de pesquisas feitas pela FGV que mostram que quanto menor a renda domiciliar, maior é a taxa de informalidade. [...] No Paraná há 900 mil pessoas que trabalham por conta própria.

"A informalidade é o principal problema do mercado de trabalho do Brasil", afirmou o pesquisador. Ele disse que no Brasil sempre houve uma preocupação muito grande com o desemprego e os trabalhadores informais nunca receberam muita atenção. "O segmento informal não é só pobre de renda, mas também pobre de políticas", considerou (FÉLIX, 2001).
}

A situação precária desse grande contingente de trabalhadores repercutiu diretamente nas cidades paranaenses. No início dos anos 2000, em diversas cidades médias do Paraná, tais como Campo Mourão, Cascavel, Maringá, Ponta Grossa e principalmente Londrina as ruas e calçadas próximas aos locais de grande fluxo diário de pessoas foram sendo progressivamente ocupadas por ambulantes e suas barracas. Assim, intensificaram-se os conflitos entre camelôs, comerciantes, pedestres, prefeituras e outros grupos sociais.

Os Camelódromos, locais de concentração dos ambulantes, multiplicaram-se nas cidades médias paranaenses ${ }^{112}$ como respostas à

112 Entre 1998 e 2000 as manchetes dos jornais indicam com alguma clareza a presença crescente do comércio ambulante e a intensa difusão de Camelódromos nas principais cidades do Paraná: 
crise do emprego e da ocupação que pesava como uma sombra sobre a sobrevivência dos trabalhadores menos qualificados. Em Londrina, segunda maior cidade do Paraná, a situação de desemprego também se mostrava crítica. Os jornais da época registraram o problema.

\section{Região de Londrina tem 101 mil sem trabalho, diz estudo. Prévia de pesquisa da UEL aponta desemprego de até $15 \%$ na cidade}

Prévia de uma pesquisa realizada pelo professor de sociologia da Universidade Estadual de Londrina (UEL), João Batista Filho, aponta 101 mil desempregados na microregião de Londrina. Somente no município, o professor calcula que, entre $10 \%$ a $15 \%$ da população, esteja desempregada atualmente. "O número considera, além dos trabalhadores parados, aqueles que sobrevivem de bicos e a mão-de-obra especializada que não arranja emprego em sua área, submetendo-se a trabalhar em qualquer função para não morrer de fome", diz Batista. (LOPES, C. 1998).

Atividades responsáveis por grande parte do emprego e da ocupação na cidade como a construção civil, a indústria têxtil e a de confecções, sofreram duros golpes na nova conjuntura, marcada pela retração dos investimentos públicos e do financiamento para habitação e

- Campo Mourão - 1998

Prefeitura teme aumento de 'camelôs'. Autorização para os ambulantes é fornecida sob critérios rígidos para garantir a organização do setor.

A Prefeitura de Campo Mourão está preocupada com a possibilidade de aumento do número de "barraqueiros" e vendedores ambulantes pelas ruas da cidade. Reuniões com os cerca de 50 vendedores que têm autorização para trabalhar em barracas padronizadas estão sendo realizadas. (SAUER, 1998)

- Cascavel - 1999

Camelódromo perde a freguesia

As lojas dos camelódromos de Cascavel, que já foram 500, hoje estão praticamente desertas. Muitas já fecharam as portas. A alta do dólar gerou uma séria crise para o comércio de produtos importados. (PEGORARO, 1999)

- Maringá - 1999

Comércio ambulante - Emissão de licença é suspensa

A emissão de novas licenças para vendedores ambulantes de Maringá foi novamente suspensa por causa do excesso de pessoas trabalhando nas ruas da cidade. É a segunda vez em dois anos que a prefeitura suspende os alvarás para ambulantes. (ZANATA, 1999)

- Ponta Grossa - 2000

Eleito vai desocupar praça tombada

Uma das mudanças da administração de Péricles de Holleben Mello (PT), prefeito eleito de Ponta Grossa, no próximo ano, será no camelódromo da cidade. Localizado na Praça João Pessoa, ao lado do terminal central de ônibus urbano, o camelódromo reúne atualmente cerca de 150 vendedores ambulantes. A proposta de Péricles é retirar as barraquinhas desse local e abrir a possibilidade dos camelôs trabalharem em outros pontos da cidade. (CERVI, 2000) 
pelo aumento da concorrência de produtos importados, especialmente os produtos chineses.

No comércio e nos serviços, o desemprego também cresceu, induzido pela inflação acelerada, pelas trocas de moeda e pela recessão. Em face dessa conjuntura continuou a crescer o número de trabalhadores que se transformou em camelôs, moto taxistas e outras atividades ditas "informais". Em razão disso, tornou-se imperiosa a necessidade de ocupar um lugar na cidade e criar condições para que as novas atividades pudessem resistir. Acirraram-se os conflitos.

No caso dos camelôs, os conflitos derivavam de diversas situações. Por exemplo, o uso de espaços públicos na área central como calçadas, ruas, praças e o próprio calçadão causando reclamação de pedestres, comerciantes e a intervenção da Prefeitura.

\section{Camelôs continuam sem local definido Nova reunião foi marcada para hoje porque não houve acordo; ambulantes não querem voltar para praça por falta de segurança}

Representantes dos vendedores ambulantes da Praça Rocha Pombo deverão se reunir hoje, às 10 horas, com o presidente da Companhia Municipal de Trânsito e Urbanização (CMTU), Gustavo Santos, para tentar chegar a um acordo sobre o local que os camelôs vão ocupar no centro da cidade. Ontem eles participaram, junto de outros representantes de órgãos municipais e Polícia Militar, de reunião no gabinete do prefeito Jorge Scaff (PSB). O encontro durou aproximadamente três horas, mas terminou sem que se chegasse a uma solução definitiva (LEÃO, 2000).

Os lojistas, diretamente afetados pela concorrência e pelo menor preço das mercadorias oferecidas pelos ambulantes, também se mobilizavam em face do crescimento contínuo desses novos atores urbanos.

\footnotetext{
Comerciantes de Londrina pedem saída de camelôs Permanência dos trabalhadores informais em frente aos estabelecimentos comerciais estaria acarretando prejuízos, dizem os proprietários

Um grupo de comerciantes da Avenida São Paulo e Rua Professor João Cândido, em Londrina, se reuniu ontem com o presidente da Companhia Municipal de Trânsito e Urbanização (CMTU), Wilson Sella, para reivindicar a saída de mais de 240 camelôs que ocupam as calçadas das duas ruas. Segundo os comerciantes, a permanência dos trabalhadores informais em frente aos
} 
estabelecimentos comerciais afasta os clientes acarretando prejuízos para os proprietários (GOUVEIA, 2001).

Também havia conflitos entre os próprios camelôs, entre aqueles já estabelecidos e os recém-chegados, entre os que haviam conquistado um ponto de vendas no Camelódromo da Avenida LesteOeste e os que se multiplicavam nas calçadas do Terminal Urbano Central. Havia ainda conflitos com o Ministério Público e a Polícia Federal, pelo fato de que muitas mercadorias eram adquiridas no Paraguai sem passar pelos devidos trâmites legais.

TRABALHO ARRISCADO

Camelôs tentam driblar fiscalização

Um dia depois do arrastão feito pela Polícia e a Receita Federal, ambulantes retornaram às ruas para comercializar mercadorias Vendedores ambulantes que comercializam mercadorias contrabandeadas - cigarros, relógios, óculos, calculadoras, flores artificiais, entre outras - nas proximidades do Terminal Urbano de Londrina estavam revoltados ontem com o arrastão realizado na véspera pela Polícia Federal e Receita Federal. A ação foi determinada pela Procuradoria da República de Londrina, que atendeu representação da Companhia Municipal de Urbanização (Comurb) e Associação dos Camelôs de Londrina (Acal).

Vários ambulantes perderam as mercadorias, mas nem assim desistiram de voltar às ruas ontem. [...]"Qualquer coisa eu saio correndo com a caixa", disse, alegando que se perder a mercadoria, não tem como comprar outra. "Nosso dinheiro está todo investido aqui." Ela trabalha junto com o marido e afirmou que o dinheiro conseguido com as vendas - de $R \$ 20,00$ a 30,00 por dia - é para sustentar os três filhos do casal.[...] Outra ambulante, indignada, dizia: "O delegado Morel (chefe da Polícia Federal em Londrina) falou não mais fazer arrastões, mas hoje cedo já pegaram a mercadoria de uma pessoa. Aqui todo mundo é pobre e desempregado. Achei um absurdo a Polícia Federal ficar aqui pegando coisa de pouco valor, como tiara e escova de cabelo, cadeado, batom" (LEÃO, 1999).

A dimensão e a intensidade dos conflitos cresceram entre 1999 e 2001, período em que novas e maiores levas de trabalhadores desempregados que passaram a atuar como camelôs, reocuparam ruas e calçadas da área central liberadas pelo deslocamento de outros ambulantes para o Camelódromo da Avenida Leste-Oeste.

A partir de meados do ano 2000, em plena campanha eleitoral realizada após a cassação do Prefeito Antonio Bellinati, paulatinamente tomou corpo a proposta de um novo e maior 
Camelódromo para a cidade. Os jornais da época registraram o início dos debates sobre a criação de um novo Camelódromo com 250 barracas que deveria abrigar os vendedores de lanches e "todos os 200 ambulantes que trabalham no quadrilátero central formado pelas avenidas São Paulo, Rio de Janeiro e ruas Sergipe e Professor João Cândido" (RODRIGUES, 2000)

A partir de outubro do ano 2000, após várias idas e vindas, cresceram as polêmicas sobre a presença e o destino dos ambulantes no centro principal de Londrina. A iniciativa desses trabalhadores de ocupar e permanecer na Praça Rocha Pombo, patrimônio histórico da cidade, tombado desde meados dos anos 1970, provocou reações enérgicas do poder público. Em dezembro do mesmo ano a Promotoria do Meio Ambiente entrou com uma ação civil pública contra o Prefeito, o diretor da Companhia Municipal de Transito e Urbanismo (CMTU) e o representante dos camelôs e presidente da Associação dos Vendedores de Produtos Nacionais e Importados (AVPNI), responsabilizando-os por danos ao patrimônio público e exigindo a desocupação da praça.

Os ambulantes deslocaram-se novamente para as ruas adjacentes ao Terminal Urbano, concentrando-se na Rua São Paulo. A efervescência do momento político da cidade abriu o espaço político para a ascensão de novos atores. Com a vitória do candidato do Partido dos Trabalhadores (PT), Nedson Michelleti, nas eleições municipais de 2000, novas perspectivas de enfrentamento da questão dos camelôs seriam efetivadas.

Segundo o Prefeito Nedson Micheleti ${ }^{113}$ ao iniciar seu primeiro mandato em 2000, encontrou um quadro de desordem e desorganização social no qual se incluíam o crescimento das ocupações urbanas, um grande número de camelôs ocupando as calçadas da região central e a expansão do moto taxi sem regulamentação efetiva da atividade.

\footnotetext{
113 As informações do relato que elaboramos sobre a atuação do executivo municipal na constituição do Camelódromo de Londrina, foram colhidas em entrevista gentilmente cedida pelo prefeito Nedson Michelleti em 17 de dezembro de 2008 .
} 
Com relação aos camelôs a primeira providência da Prefeitura foi cadastrar os ambulantes concentrados nas imediações Terminal Urbano Central identificando aqueles que estavam diretamente empenhados na atividade comercial de forma regular e contínua. Segundo o Prefeito Nedson Micheleti:

O cadastramento foi rigoroso e foi efetuado no nome de cada pequeno comerciante, evitando a permanência de pessoas que vendiam mercadorias pertencentes a terceiros e que não tinham uma relação direta com a prática comercial. Evitamos também que aqueles que eventualmente usavam o espaço do camelódromo para outras práticas como o jogo, fossem desistindo de ficar naquele local, seja por que não se adaptaram à nova situação, uma vez que trabalhavam para terceiros, seja por que sua atividade passou a ser dificultada e vigiada pelos próprios camelos que se regularizaram e que não queriam ter problemas com a fiscalização. Assim o número total de camelos diminuiu.

Os representantes dos ambulantes intensificaram o diálogo como a nova administração municipal em torno da proposta de constituir um novo Camelódromo ${ }^{114}$.

Para viabilizar o novo Camelódromo a Prefeitura estabeleceu uma estratégia de ação na qual, após o cadastramento, o passo seguinte foi a interdição e a desafetação do uso público de um trecho da Rua São Paulo entre o Terminal urbano e o Museu Histórico onde foi provisoriamente construído um conjunto de 220 barracas padronizadas. Esse novo ajuntamento que concentrou os ambulantes da região central, congelando o número desses trabalhadores, permitiu à prefeitura um dimensionamento mais claro do novo Camelódromo.

Dessa forma, a partir de meados de 2001, um segundo agrupamento de camelôs, ainda maior que o do primeiro Camelódromo,

\footnotetext{
${ }^{114}$ Em meados de 2001 os representantes dos camelôs procuraram a administração municipal para apresentar sugestões para a realocação do comércio ambulante na região central, conforme indica a reportagem a seguir: "Os camelôs do centro de Londrina querem instalar um centro comercial popular com espaço para atividades culturais no terreno público localizado entre o Pronto Atendimento Infantil (PAI) e a Supercreche, na Rua Benjamin Constant. Esta é a única grande área pertencente à Prefeitura, situada no miolo da região central de Londrina. [...] Agora a Associação dos Vendedores Ambulantes da Rocha Pombo sugere que seja construído no local uma espécie de shopping popular, nos moldes do Mercado Modelo de Florianópolis (SC). Na quarta-feira Manoel Barbosa, presidente da associação, apresentou a idéia para o presidente da CMTU, Wilson Sella.[...] Sella diz que endossa a idéia dos camelôs, mas o local onde este espaço será instalado ainda não foi definido. Desde que assumiu a CMTU, há quatro meses, a solução para os camelôs está em estudo". (PELLEGRINO, 2001)
} 
passou a funcionar no referido trecho da Rua São Paulo reunindo 220 camelôs em barracas de $1,5 \mathrm{~m}$ de largura. Essa nova concentração constituiu o segundo local de origem da grande maioria dos camelôs que foram para o novo Camelódromo de Londrina na esquina das Ruas Mato Grosso e Sergipe.

Paulatinamente o executivo municipal estreitou as relações com os representantes das associações dos camelôs, especialmente os que eram representados pela Associação de Vendedores de Produtos Nacionais e Importados da Praça Rocha Pombo (AVPNI) que contava com mais de 150 associados. Essa associação deu origem a uma Organização Não governamental: a ONG Canaã, que mais tarde seria responsável pela administração do novo Camelódromo.

O Prefeito Nedson relatou que a essa altura, isto é, após o cadastramento e concentração dos ambulantes nas instalações provisórias da Rua São Paulo, a Prefeitura já havia traçado o plano de constituir um novo Camelódromo e nele reunir os camelôs do primeiro Camelódromo e também os do novo ajuntamento provisório.

Conforme Micheleti, a intenção era conduzir os camelôs cadastrados a um imóvel em que pudessem se organizar coletivamente. Para tanto, foram feitas visitas e contatos com outras prefeituras como as de Florianópolis, Curitiba, Cascavel, Foz do Iguaçu e outras do interior de São Paulo, que haviam realizado iniciativas semelhantes, criando espaços destinados a abrigar os ambulantes, retirando-os das ruas. Constataram problemas trazidos para a administração municipal nos modelos encontrados.

Nessas visitas, a equipe percebeu que, onde os Camelódromos foram implantados em imóveis públicos, havia uma série de restrições e entraves administrativos que traziam complicações indesejáveis para a administração municipal tais como: licitações freqüentes, fiscalização e normatização do uso, manutenção, etc. Do lado dos camelôs esses entraves poderiam encarecer sua atividade ou limitá-la e, assim, esses Camelódromos tendiam a se esvaziar e os camelôs a 
voltar para as ruas. Por isso, o executivo municipal foi definindo uma série de parâmetros para dar forma ao novo Camelódromo:

- O espaço para o Camelódromo deveria ser privado. Assim não caberia diretamente à prefeitura a regulação da atividade interna e não haveria necessidade de licitação decorrente de contratos de uso dos espaços com duração específica, entre outras medidas legais;

- O contrato de aluguel não poderia ser celebrado em nome da prefeitura. Os camelôs deveriam formar associações ou entidades coletivas para gerir o empreendimento e a prefeitura atuaria por meio de convênios com essas entidades dando suporte legal e financeiro a algumas de suas ações.

Com base nesses parâmetros, ficou acertado que a prefeitura auxiliaria a associação encarregada da administração do novo Camelódromo, arcando com os aluguéis durante os primeiros 24 meses. Para isso, a administração municipal apoiou-se na lei municipal de incentivo as empresas ${ }^{115}$.

$\mathrm{Na}$ prática, a configuração do novo Camelódromo de Londrina ganhou seus contornos ao longo do ano de 2002. Os protestos e contraposições dos tradicionais adversários políticos da administração do Prefeito Nedson, a exemplo da Associação Comercial e Industrial (ACIL), subiram de tom das críticas à medida que o novo camelódromo se configurava. O Ministério Público foi insistentemente acionado e prontamente se mobilizou, convocando as Policias Federal e Civil, que realizaram investidas sucessivas em 2002 e recolheram grande parte das mercadorias comercializadas pelos camelôs.

Os próprios camelôs que segundo o Prefeito, antes eram dominados pelo político Antonio Belinati, também se voltaram contra a Prefeitura e temiam se afastar do terminal urbano. Com muito custo

\footnotetext{
${ }^{115}$ Lei Municipal 9988 de 2006 e Lei 4320 de 1964.
} 
reconheceram alguns pontos positivos nas iniciativas da Prefeitura segundo Micheleti.

A situação era complexa e a Prefeitura contava com poucos apoios políticos para essa empreitada. Aos poucos, conforme vislumbraram melhores possibilidades de se fixar no comércio com a regularização de suas atividades, parte dos camelôs aliou-se ao Prefeito Nedson, apoiando fortemente sua reeleição em 2004.

A organização interna do novo Camelódromo foi definida pela Prefeitura Municipal ao longo de 2002, período em que o diálogo com os representantes dos camelôs foi se tornando mais freqüente e por vezes mais tenso. A estrutura adotada baseou-se na necessidade de abrigar os 316 camelôs então cadastrados pela Companhia Municipal de Urbanização (COMURB). No plano do executivo municipal a forma do novo camelódromo seria a de um espaço privado gerido pelos próprios camelôs e apenas incentivado pelo poder público. $O$ arcabouço legal foi o mesmo que permitia à Prefeitura fazer concessões e apoiar a implantação de novas empresas no município. Após várias especulações, idas e vindas, o Executivo municipal e os representantes dos camelôs definiram o local para o novo camelódromo, um edifício de 2 andares, onde funcionara uma fábrica de móveis.

De início a localização suscitou muitas dúvidas nos camelôs temerosos de se afastar do Terminal Urbano. No entanto, para muitos, as novas condições eram muito superiores àquelas em que trabalhavam. $O$ novo camelódromo foi internamente adaptado com construção de 316 boxes, isto é, pequenos espaços padronizados medindo 2 metros de largura e comprimento variável, entre 1,5 e 2 metros $^{116}$.

O custo da reforma que adaptou o local para que fosse ocupado pelos camelôs foi bancado pela Prefeitura. Também ficou definido que durante os primeiros 24 meses o aluguel do imóvel seria pago pelo

\footnotetext{
116 "No novo Camelódromo estão previstas 316 bancas, sendo que 146 funcionarão no primeiro andar e outras 170 unidades no térreo. O projeto contempla também, no pavimento superior, a praça de alimentação. [...] Os boxes terão dois metros de largura e comprimento variável, entre dois metros (184 boxes), 1,8 metro (115 boxes) e 1,5 metro (17 boxes)." (ESPÍNDOLA, 2002)
} 
município. Segundo o Prefeito Nedson tratava-se de, durante um prazo determinado, criar condições para incubar atividade e torná-la o mais formal possível, sem que a Prefeitura ficasse permanentemente responsável pelo empreendimento.

Em janeiro de 2003 os camelôs se transferiram do antigo Camelódromo da Avenida Leste-Oeste e das instalações improvisadas da Rua São Paulo para o Camelódromo de Londrina na Rua Mato Grosso, esquina com a Sergipe. A administração do novo Camelódromo ficou a cargo da ONG Canaã, uma Organização Não Governamental criada a partir das associações que representaram os camelôs desde meados dos anos 1990: a Associação do Camelódromo de Londrina (ACAL) criada pelos camelôs instalados no antigo Camelódromo e a Associação dos Vendedores de Produtos Nacionais e Importados (AVPNI) formada pelos camelôs concentrados na Rua São Paulo.

O auxílio da Prefeitura nos dois primeiros anos foi fundamental para que o empreendimento pudesse se firmar. Desde então, o formato que o Camelódromo de Londrina assumiu foi imitado e se reproduziu na cidade. A reunião de grande quantidade de pequenos comerciantes oferecendo mercadorias diversas em um mesmo local, dividindo custos de manutenção como água, luz, telefone, aluguel, etc., gera condições concretas para a sobrevivência desses empreendimentos, ainda que os resultados comerciais sejam, na maioria dos casos, bastante modestos: um faturamento bruto mensal de $\mathrm{R} \$ 5.447,00^{117}$ em média, no caso do Camelódromo de Londrina.

Essa informação foi a mais difícil de obter em relação ao trabalho de campo no Camelódromo, apenas 63 estabelecimentos informaram o seu faturamento, alguns de forma aproximada. O maior valor informado foi de $\mathrm{R} \$ 27.000,00 \mathrm{em}$ um estabelecimento que comercializa diversos produtos eletrônicos e o menor informado foi de $R \$$ $1.500,00$ em uma loja que vende DVDs.

\footnotetext{
117 A média foi calculada com base nas informações de 61 estabelecimentos, desprezando assim as duas informações discrepantes referentes ao maior e menor valor informados.
} 
A perspectiva de enfrentar o desemprego, a grande rotatividade de mão de obra praticada pelas empresas e ainda encontrar alguma prosperidade, fez multiplicar empreendimentos semelhantes ao Camelódromo de Londrina:

\section{Camelôs comemoram crescimento da atividade}

A atividade de camelô cresce a cada dia em Londrina e, segundo apurou a reportagem numa consulta informal realizada ontem, garante renda mensal de, no mínimo, $\mathrm{R} \$ 800$ por pessoa. Legais ou ilegais, os vendedores que conseguiram se estabelecer nos camelódromos da cidade sentem-se satisfeitos com seus negócios e dizem que o "mercado" está em expansão.

$\mathrm{E}$ os negócios devem crescer ainda mais com a inauguração do novo camelódromo, no coração da cidade, na antiga Galeria do Cine Augustus. A previsão é de que a partir de 5 de outubro pelo menos pequenos 300 boxes iniciem as atividades. (FRAZÃO, 2006)

O empobrecimento e a instabilidade do cotidiano, que se tornaram crônicos com o desemprego e a queda nos valores médios das remunerações pela oferta superabundante e concentrada de força de trabalho, continuaram a mover mais e mais pessoas, homens e mulheres, para a vida de camelôs. Por conta dessa possibilidade e de toda a ideologia do negócio próprio, insuflada pelo desemprego e também pelas baixas remunerações oferecidas a funções acessíveis àqueles que não possuem condições de disputar as minguadas funções mais bem remuneradas, multiplicaram-se os camelódromos na cidade.

Em Londrina há, atualmente, até mesmo o aproveitamento específico de imóveis centrais que foram reformados de maneira a se assemelharem ao novo Camelódromo e que se tornaram negócios imobiliários nos quais, cada pequeno Box, é alugado por valores iniciais que variam conforme a posição dentro do edifício, variando de $R \$ 540,00$ a 900,00 (valores de 2007, quando um dos negócios estava sendo inaugurado). Esse é o caso da Galeria Benjamin, edifício de 2 andares situado na Rua Sergipe, em frente ao Terminal Urbano, destinado a abrigar pequenos estabelecimentos comerciais semelhantes aos do novo Camelódromo. 
Alguns camelôs antes instalados no novo Camelódromo, por exemplo, resolveram eles mesmos iniciar outro Camelódromo bancando o aluguel do edifício, sua adaptação, regularização e administração. Assim em meados de 2006 surgia o Camelódromo Central, situado em pleno calçadão da Avenida Paraná prevendo abrigar até trezentos novos pequenos comerciantes. Também na Avenida Saul Elkind, zona norte da cidade, subcentro definido pela concentração de atividades comerciais e de serviços um espaço oraganizado com características semelhantes as do Camelódromo de Londrina foi construído. É o "Camelódromo Cincão", nome que é uma referência aos cinco conjuntos habitacionais construídos no final dos anos 1970 e que deram origem à estruturação de toda aquela parte da cidade.

O Camelódromo não se reproduziu apenas como forma - no sentido de modelo. O próprio Camelódromo, por suas condições de funcionamento interno e entrosamento com o meio, impôs certa seletividade sobre aqueles que poderiam atuar nele. Assim muitos dos que vieram das ruas, dos dias agitados de confrontação e de esperança em um novo modo de trabalhar e de viver foram aos poucos sendo expulsos pela dinâmica da propriedade privada e do mercado que determinaram os limites da permanência.

Algumas entrevistas indicaram que as características pessoais e a trajetória de cada um influíram sobre a permanência ou não no Camelódromo de Londrina. Algumas pessoas que haviam se adaptado à rua temiam que o novo empreendimento fracassasse e que a perda fosse além de suas possibilidades, temiam que o movimento de clientes não fosse suficiente para sustentar o empreendimento. Alguns tiveram dificuldades em gerir o negócio e venderam seu ponto, mas continuaram a trabalhar no mesmo estabelecimento como assalariados. Outros preferiram alugar o box e passaram a trabalhar no Camelódromo como assalariados de amigos e parentes que também possuíam um box.

Alguns alugaram o box que thes foi destinado e procuraram adquirir outros, passando a explorar os aluguéis desses estabelecimentos. 
Para Edmilson Gonzáles, um de nossos entrevistados e que à época, em meados de 2007, era presidente da ONG Canaã, restariam como proprietários dos estabelecimentos comerciais do Camelódromo, cerca de $20 \%$ das pessoas que participaram do momento de embate e de transferência da rua para o novo local. O entrevistado apontou ainda um perfil um pouco diferente entre os que estavam "batalhando nas ruas" e os que hoje permanecem no Camelódromo. Segundo Gonzáles

As pessoas que estão aí hoje tiveram alguma experiência no comércio antes. Ou como vendedores de lojas, ou vendedor externo, ou gerente de loja, caixa e até dono de pastelaria. É um pessoal que ao se ver desempregado ou quebrado, resolveu se arriscar e diante de oportunidade de ter um lugar aqui no Camelódromo tratou logo de começar a trabalhar.

Gonzáles relatou também que: "O inicio, especialmente os dois primeiros anos, foram muito difíceis e houve muita inadimplência, até que as coisas fossem se ajeitando". Nesse período (os dois primeiros anos) muitos camelôs deixaram o Camelódromo repassando o estabelecimento a outros como dissemos. 


\section{3 - A gênese do Moto Táxi}

Ao longo dos anos 1990, multiplicaram-se nas metrópoles brasileiras e também em muitas cidades do interior do país formas de transporte denominadas de clandestinas, informais ou até mesmo ilegais. Conforme Mamani (2004) as estimativas do governo davam conta de que, no final dos anos 1990, haveria cerca de 40 mil veículos como vans, kombis, pick-ups cobertas envolvidos no transporte informal pelo Brasil afora. Entretanto, por se tratar de atividade informal, os dados não são precisos. O fato é que, apesar de toda repressão, essas modalidades de transporte não cessaram de se multiplicar no país a partir de meados dos anos 1990.

Segundo a Associação Nacional de Transportes Urbanos (1997) em maio de 1997, havia modalidades de transporte informal em 26 capitais e em 18 cidades de porte médio. O período entre 1995 e 1997 em especial parece ter sido marcado por uma acelerada proliferação dessas iniciativas espalhadas por todo o país, dentre as quais se inclui o Moto Táxi.

Segundo o IBGE ${ }^{118}$, em 2008, o serviço de Moto Táxi já estava amplamente difundido em todo território nacional, com presença em nada menos que $52 \%$ dos municípios brasileiros. Nesse conjunto destacam-se os municípios com população entre 50 e 100 mil habitantes, dentre os quais se verifica o maior percentual de municípios com essa atividade (69\%). O serviço de Moto Táxi aparece com menos freqüência nas Regiões Sul e Sudeste e está presente em mais de $70 \%$ dos municípios das Regiões Norte, Nordeste e Centro oeste.

\footnotetext{
118 "Em 52,7\% dos municípios, há serviço de transporte por mototáxi. Percebe-se maior presença deste serviço naqueles com mais de 50000 a 100000 habitantes, 69,0\%. Nos municípios com mais de 20000 a 50000 habitantes, essa proporção é de 64,3.\%” (Perfil dos Municípios Brasileiros 2008, p.58)
} 


\section{Mapa 9}

Brasil: distribuição do serviço de Moto Táxi por Região - 2008

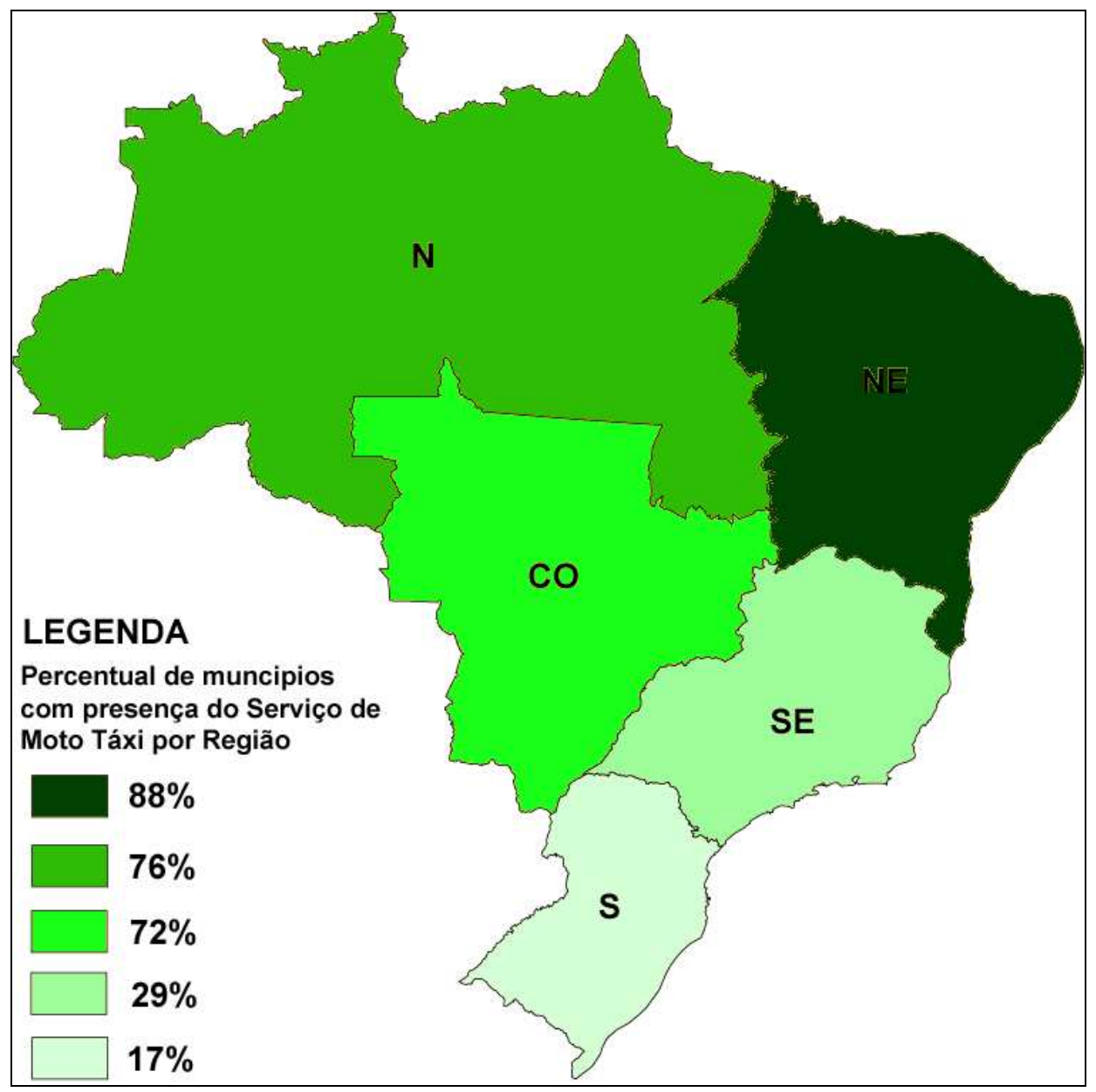

Fonte: IBGE, Perfil dos Municípios 2008

\section{Gráfico 14}

Brasil: percentual de municípios com presença do serviço de Moto Táxi por Macrorregião, 2005 - 2008.

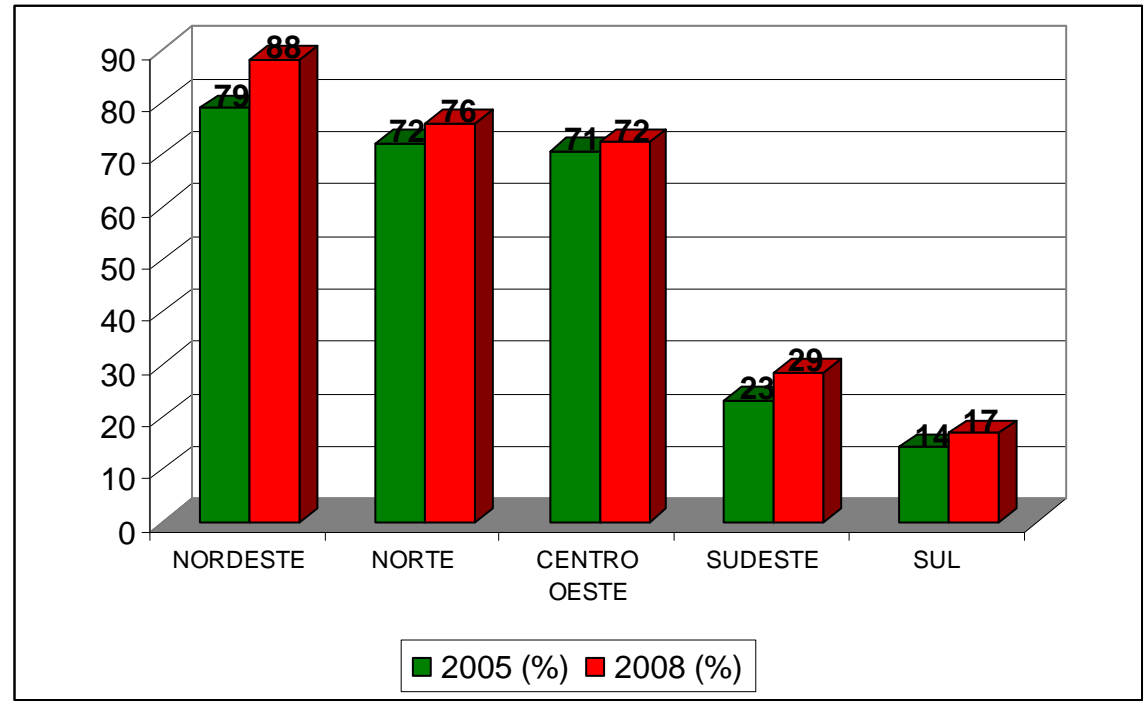

Fonte: IBGE, Perfil dos Municípios 2008 
A rápida difusão do serviço de Moto Táxi está ligada à convergência de pelo menos três processos distintos: o desemprego, as baixas e baixíssimas remunerações dos postos de trabalho disponíveis à maioria dos trabalhadores menos qualificados e a necessidade crescente de mobilidade no meio urbano.

O momento em que o desemprego se alastrou pelo país coincide com a expansão dos transportes alternativos no país. Além do crescimento do desemprego, as transformações na estrutura produtiva implicaram, para muitos trabalhadores menos qualificados, a perda de perspectivas de recuperação de um emprego formal, tornando a desocupação um problema crônico.

No período atual, além do desemprego crônico, as baixas remunerações de muitos empregos formais, sobretudo na Construção Civil e nos Serviços, impuseram às pessoas a procura por alguma forma de ocupação e renda. Nesse sentido, o Moto Taxi passou a ser uma alternativa de ocupação que permitiu a cerca de 500 mil trabalhadores em todo Brasil ${ }^{119}$, afastarem no curto prazo, os fantasmas do desemprego, das remunerações muito baixas e da instabilidade que acarretam. Esse fato, aliado à periferização da população de baixa renda, afastada dos centros e subcentros das cidades em que se concentram as oportunidades de emprego e ocupação, ampliou ainda mais as demandas não atendidas por mobilidade por parte de um enorme contingente de pessoas concentradas em áreas urbanas de diferentes dimensões.

A mobilidade urbana, entendida como o deslocamento diário da população, é um fenômeno que "tem como causa a crescente separação geográfica entre os diversos lugares de atividade e os lugares de residência" (GEORGE, 1983, p.190). Há, portanto, aspectos relativos à dinâmica interna das cidades que interferem na expansão das modalidades ditas "informais" de transporte e dos conflitos que essa expansão tem gerado.

\footnotetext{
${ }^{119}$ As informações são de Robson Alves presidente da FENAMOTO, Federação Nacional dos Motoboys e Mototaxistas (AGÊNCIA ESTADO, [2009?]).
} 
Esses fatores de ordem local combinam-se às transformações macroestruturais, alimentando a expansão dos transportes alternativos, bem como com sua velocidade de propagação. Os contextos urbanos diferenciados por trás dessa expansão são importantes para a análise da questão. Embora, existam aspectos comuns como a legislação nacional de trânsito, os conflitos de competência legislativa sobre o tema dos transportes e a premência da necessidade por mobilidade que caracteriza o modo de vida urbano, há outras variáveis que afetam a questão e que requerem uma análise mais contextualizada. São variáveis como: a estrutura urbana, as dimensões da cidade em termos físicos e demográficos, a intensidade da segregação sócioespacial, a disponibilidade e a eficiência do transporte público, a dinâmica econômica e social da cidade, a força política e as alianças que os trabalhadores do Moto Táxi conseguem ou não fazer, entre outras.

Em geral, nas cidades brasileiras, as dificuldades de mobilidade são determinadas pelas deficiências e pelo custo do transporte coletivo, pelas longas distâncias a percorrer para ter acesso às áreas centrais, escolas, hospitais ou indústrias e pela impossibilidade de se deslocar com rapidez, ocasionada pelo tráfego lento ou pela demora e pelos trajetos das linhas de ônibus.

A circulação interna nas cidades, especialmente as maiores, torna-se intensa à medida que mais e mais fluxos de diversas naturezas se concentram e convergem para o meio urbano. A grande prioridade dada ao uso do automóvel na organização dos fluxos urbanos em detrimento de outras formas de deslocamento, especialmente dos pedestres, (YAZIGI, 2000, p.282), acompanha o ritmo da urbanização, a intensificação dos consumos e a expansão das classes médias.

Contudo, para os que não têm condições de possuir um carro, a imobilidade relativa se torna real e cresce proporcionalmente às deficiências do transporte público. Frente a essas deficiências e à necessidade de se deslocar pela cidade, muitas pessoas se dispõem a enfrentar os riscos de andar na garupa de uma moto. 
A alternativa oferecida pelo Moto Taxi é a que mais se aproxima do transporte individual proporcionado pelo automóvel, pois oferece um deslocamento ágil e atende de forma individualizada às necessidades de deslocamento das pessoas.

O aumento do número de motocicletas nas cidades brasileiras, sobretudo as grandes e médias, é um dado que pode ser constatado pela velocidade com que nos últimos dez anos cresceu a produção interna desse bem. Segundo a Associação Brasileira dos Fabricantes de Motocicletas, Motonetas, Bicicletas e Similares (ABRACICLO), entre 1998 e 2007, a produção de motociclos no Brasil mais do que triplicou, passando de 475.725 unidades para 1.734.349 unidades. A frota de motociclos se expandiu em todas as grandes regiões do país, e respondia por $21 \%$ da frota nacional no inicio de 2007 .

Essa rápida difusão parece estar aliada às possibilidades que a motocicleta oferece como transporte individual de custo relativamente baixo, se comparado ao de um automóvel. Ademais, existem facilidades para a compra desse bem, como os financiamentos e os consórcios, as duas principais formas de compra segundo a ABRACICLO. Contam também seu consumo de combustível menor que de outros veículos destinados ao transporte individual, à manutenção e é claro sua agilidade e desempenho nos congestionamentos urbanos.

Esse contexto de expansão do consumo de motocicletas no país, aliado a necessidades crescentes de mobilidade e transporte público insuficiente, possibilitou a expansão do serviço de Moto Táxi. Segundo Fonseca (2005, p.56):

Independentemente do tamanho das cidades, o moto táxi surge como alternativa informal, clandestina, a um transporte coletivo precário ou mesmo inexistente. Apresentando vantagens como rapidez e preços reduzidos, ele atende, sobretudo às demandas das classes de renda mais baixa, ao aliviar o peso do "transporte" em seu orçamento doméstico e ao garantir acesso a lugares não atendidos por ônibus, seja pela falta de pavimentação ou violência desses lugares, seja pela baixa lucratividade que oferece às empresas formais.

Além de preços mais reduzidos, o serviço de moto táxi apresenta uma vantagem em comparação a outros serviços de transporte alternativo, como o de vans e kombis: a exclusividade do 
atendimento. Diferentemente destas modalidades de transporte, que têm percursos e horários determinados e operam com "lotada", o moto táxi se estrutura como um serviço personalizado, variando seus itinerários, preços e até formas de pagamento de acordo com o cliente.

Discordamos da autora quanto à generalização de algumas afirmações, tais como: "Independentemente do tamanho das cidades, o moto táxi surge como alternativa informal, clandestina, a um transporte coletivo precário ou mesmo inexistente". Em Londrina e Cascavel, no Paraná, e em diversas cidades do interior paulista, o Moto Táxi encontrase amparado por legislação municipal, atuando em toda cidade e não apenas em áreas desprovidas de infraestrutura urbana. Ademais, em Londrina pelo menos, o transporte por ônibus apresenta condições razoáveis de funcionamento.

De qualquer forma, fica evidenciado que, é na brecha das demandas não satisfatoriamente atendidas da população mais pobre e distante das áreas centrais que as atividades do circuito inferior, a exemplo do Moto Taxi, encontram as oportunidades para se desenvolver.

Em diversos municípios brasileiros como Camocim e Sobral no Ceará, em Lins e Franca em São Paulo essa nova atividade se manifestou por volta de 1997 e 1998 (CAVECHINI; SOUZA; PAGANOTTI, 2004, p.1). Em Londrina as primeiras notícias sobre a novidade também datam de 1997.

A Companhia Municipal de Urbanismo (Comurb) pretende entregar até o final do mês para a Câmara de Vereadores, parecer técnico sobre o trabalho das empresas de moto-táxi.[...] Atualmente, quatro empresas de moto-táxi de Londrina estão trabalhando graças a uma liminar concedida pela Justiça (CUNTO, 1997).

Em Londrina, assim como no caso do Camelódromo, a consolidação da atividade se deu por meio de embates entre diversos atores sociais: mototaxistas, Prefeitura, sindicato de taxistas e empresas de ônibus do transporte coletivo municipal. A situação foi se agravando a partir de 1997 com o rápido aumento do número de pessoas envolvidas na atividade. Inicialmente, ainda em 1997, a Câmara Municipal rejeitou a regularização do novo serviço levando os mototaxistas a produzir ruidosas 
manifestações no centro de Londrina ${ }^{120}$. Apenas três Centrais - empresas que recebem as chamadas solicitando as corridas e acionam os mototaxistas - conseguiram decisões liminares da justiça e podiam funcionar com algum amparo legal ${ }^{121}$.

A organização dos mototaxistas foi fundamental para reverter essa situação. No final de 1998, a recém-formada Associação Moto Taxi Norte do Paraná, representando mais de 700 mototaxistas de Londrina, propôs um projeto de Lei de autoria popular para o qual recolheram milhares de assinaturas (HORTA, 1998).

Como resultado desse esforço, o projeto de Lei que previa a criação dos serviços de Moto Taxi e Moto Entrega em Londrina, tramitou pela Câmara Municipal ao longo de 1999, e foi assinado pelo então Prefeito Antonio Belinati em janeiro de 2000, ano de intensa disputa política e eleitoral ${ }^{122}$.

De modo semelhante ao que ocorrera com os camelôs, a situação dos mototaxistas só chegaria a uma condição relativamente estável do ponto de vista legal com a regulamentação do serviço, realizada durante a administração do Prefeito Nedson Micheleti a partir de 2001. De acordo com o Prefeito Nedson, ${ }^{123}$ no caso dos mototaxistas, foi mais fácil chegar a um acordo, uma vez que a Lei $8.052^{124}$, criada na administração anterior, fornecia base legal para atuação dessa categoria. Também porque as resistências à nova atividade haviam diminuído.

\footnotetext{
${ }^{120}$ Os jornais da época registraram os protestos da nova categoria: "Os moto-taxistas fizeram ontem pela manhã uma passeata em protesto contra a decisão da Câmara de Vereadores que, na sessão de anteontem, retirou definitivamente de pauta o projeto que regulamenta o serviço na Cidade. Revoltados também com o parecer contrário da Companhia Municipal de Urbanização (Comurb) ao projeto, os manifestantes fizeram uma pausa em frente à Prefeitura. “Queremos trabalhar. Queremos trabalhar', gritavam.” (MORAIS, 1997).

121 Apenas as Centrais Londrina Zona Norte (que não existe mais com esse nome), Lindóia e Solução, atualmente as duas maiores Centrais da cidade operavam com base em liminares ou sentenças do tribunal de justiça. (HORTA, 1998)

${ }_{122}$ Os Mototaxistas procuraram tirar proveito da acirrada disputa eleitoral e apresentaram o projeto em um momento em que as disputas políticas na cidade estavam acirradas com a possibilidade de cassação do então Prefeito Antonio Belinati, que acabou ocorrendo no ano 2000. O processo de cassação e as disputas a ele ligadas acabaram por atrasar a regulamentação da Lei № $\mathbf{8 . 0 5 2}$ de 4 de janeiro de 2000 .

${ }^{123}$ Conforme entrevista com o Sr. Prefeito Nedson Micheleti em 17 de dezembro de 2008.

${ }^{124}$ A Lei 8.052 de janeiro de 2000 já sofreu alterações., a última delas em 27 de dezembro de 2002 quando foi alterada pela Lei 9.020, sancionada pelo Prefeito Nedson Micheleti.. Essa nova Lei definiu um número máximo de 1.000motocicletas ativas no serviço de Moto Taxi e um número máximo de 60 centrais em toda cidade.
} 
Os taxistas, por exemplo, perceberam que o novo serviço atendia a um público de menor poder aquisitivo e os que podiam pagar por uma corrida convencional de táxi não se dispunham a andar na garupa de uma moto. Os proprietários de empresas de ônibus por sua vez tentaram impedir a legalização da atividade alegando a insegurança desse tipo de transporte e os prejuízos que esse tipo de concorrência traria. No entanto, rapidamente o Moto Táxi foi adotado pela população.

A partir de 2001, a Prefeitura, por meio da Companhia de Municipal de Urbanização e Transportes (CMTU), estabeleceu as normas ${ }^{125}$ para a atuação dos mototaxistas que concretamente se integraram ao cotidiano de Londrina.

${ }^{125}$ Dentre as normas que definem o Serviço de Moto taxi temos as seguintes determinações:

- Para o condutor: ter Carteira de Habilitação categoria "A", curso de formação para condutor de veículo mototáxi, atestado médico, com avaliação física e psicopedagógica, certidão de antecedentes criminais, apólice de seguro de responsabilidade civil e facultativo, carta de apresentação e vínculo junto à uma Central e alvará de motorista autônomo.

- Para o veículo: a moto deve ter o Certificado de Registro de Veículo licenciado no Município de Londrina em nome do autorizado, a motocicleta deverá ter tempo de uso máximo de 05 anos, potência mínima de 125 cilindradas e máxima 250 cilindradas, sendo vedado o tipo "trail", a motocicleta será vistoriada e então será fornecida a autorização para emplacamento categoria "ALUGUEL" junto ao DETRAN-PR. e a moto poderá ter no máximo 7 anos de uso.

Uma vez cumpridas as determinações, o mototaxista recebe o Certificado de Condutor de Moto Taxi com validade periódica, o que o obriga a revalidação semestral dessa permissão. 


\subsection{1 - A localização, distribuição e caracterização das Centrais de Moto Táxi}

Elemento de inserção do serviço de Moto Taxi na estrutura urbana, as centrais estão presentes em praticamente todos os quadrantes da cidade, mas há um número maior delas na região central: cerca de 20 centrais ou $42 \%$ do total.

Mapa 10

Londrina: distribuição das Centrais de Moto Taxi, 2008

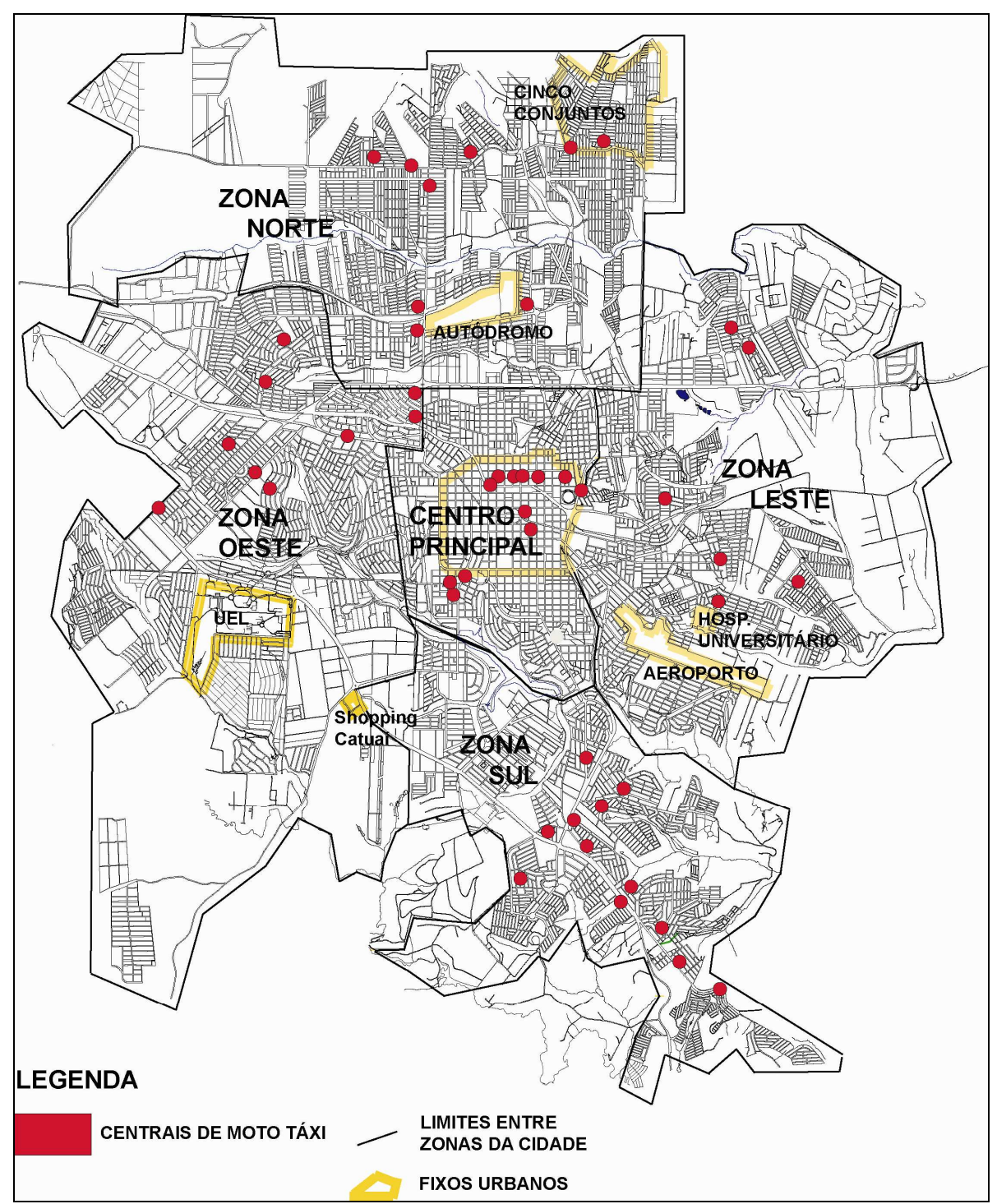

Fonte: Trabalho de campo, 2008 
A localização e a distribuição das centrais de Moto Taxi em Londrina nada tem de aleatória; elas derivam exatamente da ordem espaço-temporal que caracteriza o meio construído, melhor dizendo, o meio geográfico em Londrina. Um dado primordial dessa distribuição é que, mesmo nas centrais localizadas no Centro Principal de Londrina, os imóveis ocupados são de baixo valor locativo ${ }^{126}$ e estão situados em áreas menos valorizadas. A exceção fica por conta da Central Rota 99, uma das maiores da cidade, que ocupava um terreno alugado na Av. Higienópolis, nas proximidades do lago Igapó. Recentemente essa Central se mudou para novas e melhores instalações na mesma avenida, em endereço muito próximo ao anterior.

Todavia, os dados mais importantes dessa distribuição se referem às centrais espalhadas pelos bairros da cidade. O primeiro deles é que, de um modo geral, elas ocupam imóveis situados nos "centros de bairro" ou em avenidas de grande fluxo, onde há alguma concentração de pequenos estabelecimentos comerciais, grandes empresas de autopeças, oficinas de conserto de caminhões, entre outros.

A proximidade com essas empresas, combinada com os fluxos de pessoas que procuram esses locais, possibilita o contato com as centrais e mototaxistas. Em todas as entrevistas que realizamos essa condição, a do contato cotidiano, foi citada como base da conquista de clientes e da construção de relações de confiança, que permite ao donos de diversos tipos de lojas: um "pet shop", um mercadinho, uma floricultura, uma farmácia isolada ou um açougue, solicitarem a um determinado mototaxista que faça, por exemplo, serviços bancários.

A proximidade permite também a conquista de passageiros que se tornam clientes freqüentes, os quais não temem andar na garupa da moto por adquirir confiança em seu condutor. Essas pessoas acabam por solicitar também outros serviços, como apanhar uma chave que se

\footnotetext{
${ }^{126}$ Ainda que não tenhamos levantado essa informação de maneira sistemática, vale ressaltar que o aluguel não foi mencionado como a principal despesa das Centrais, e sim o telefone. Além disso, com base nas entrevistas e questionários aplicados nas 35 Centrais visitadas apuramos que o meio valor pago de aluguel era de $R \$ 1.500,00$ em uma Central situada na Av. Leste-Oeste bem próxima ao Terminal Urbano Central. Em 2008, nas Centrais localizadas nos bairros os valores variavam entre $\mathrm{R} \$ 500,00$ e 800,00
} 
esqueceu, pegar algum documento em outra cidade, enfim uma variada gama de situações.

O segundo dado é que as centrais se localizam nas proximidades de bairros em que há concentração de responsáveis por domicílios com ganhos médios de até 2 salários mínimos. Considerando também as indicações dos bairros de onde as centrais recebem mais chamadas, foi possível constatarmos que, sobretudo nas centrais espalhadas pelos bairros, são as pessoas que vivem em famílias com menores rendimentos os principais usuários desse serviço, o que reforça sua caracterização como atividade do circuito inferior.

O terceiro aspecto, o qual reforça os anteriores, é a ausência de centrais no setor sudoeste de Londrina, que, grosso modo, pode ser delimitado como a parte da cidade que se estende na direção sul e sudoeste, entre a Universidade Estadual Londrina, o Shopping Catuaí e o Lago Igapó. Essa parte da cidade reúne diversos condomínios fechados, alguns bairros elitizados como o Jardim Bela Suíça e a Gleba Palhano, local de recente e veloz processo de verticalização com edifícios de padrão médio e alto, que se expressam no valor do metro quadrado construído, o qual supera a casa de $R \$ 2.000,00$.

Nessa área, além da concentração de pessoas com rendimentos médios e elevados (acima de 5 salários mínimos), a própria configuração do meio construído constitui obstáculo à instalação das centrais, uma vez que nos bairros citados, não se verifica a presença de centros de bairro característicos como em outras partes da cidade. Vale lembrar, no entanto, que há demandas para corridas realizadas pelos mototaxistas.

As concentrações de estabelecimentos comerciais e de serviços nas avenidas da parte sudoeste da cidade ou em outros logradouros, em geral, são pertencentes ao circuito superior ou superior marginal e sua ligação com a circulação intra-urbana é muito mais próxima dos automóveis particulares que, são objetos comuns, entre as classes médias que os freqüentam. 


\section{Mapa 11}

Londrina: distribuição das Centrais de Moto Táxi e setores censitários com no mínimo $20 \%$ de responsáveis pelo domicilio com rendimentos de até 2 S.M.

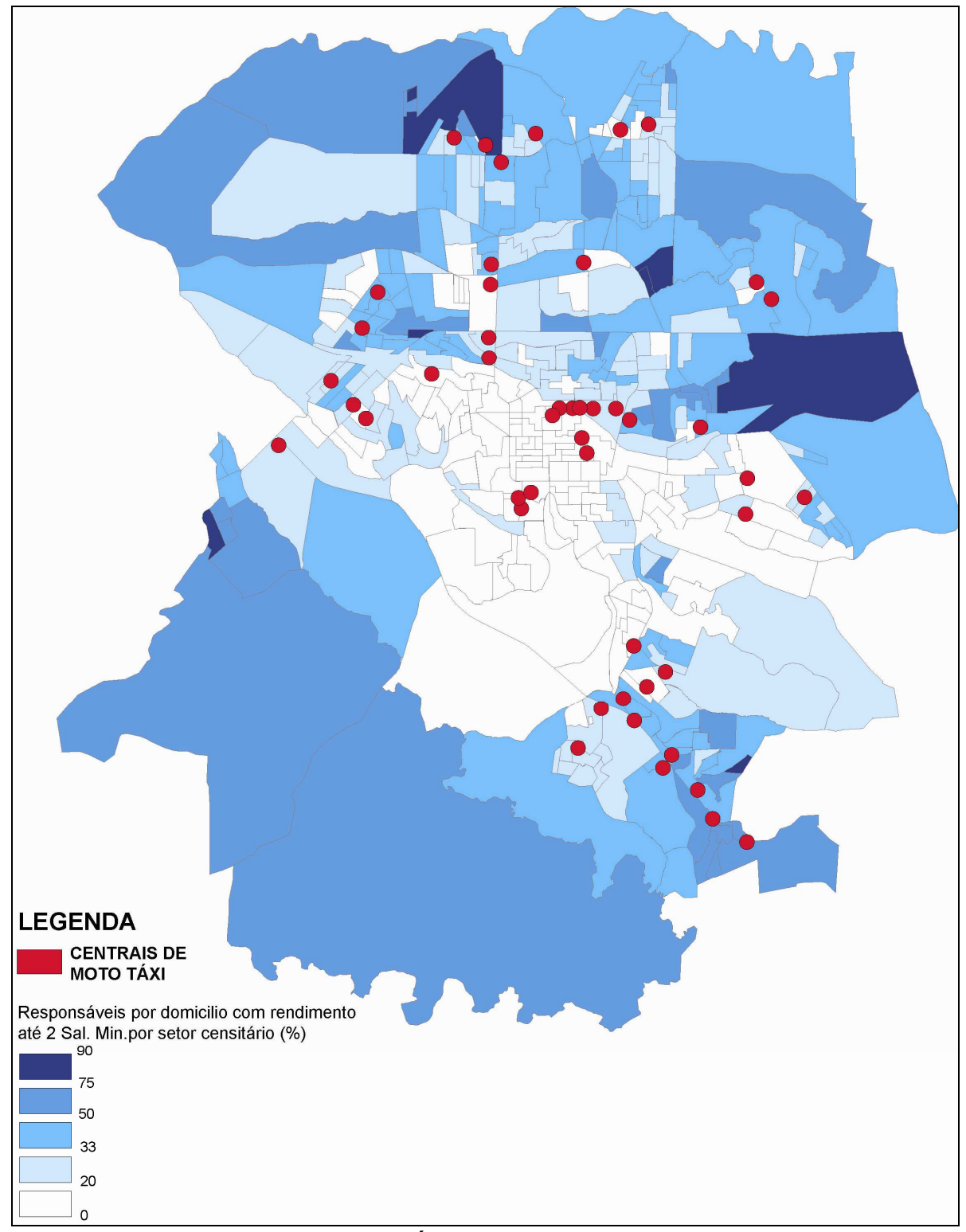

Fonte: IBGE, Censo Demográfico 2000 e Trabalho de Campo, 2008

O vínculo dos mototaxistas com a central é estabelecido por lei como condição para o exercício da atividade. O mototaxista paga ao proprietário da central uma diária referente a um período de 12 horas que, no início de 2008, variava de $\mathrm{R} \$ 5,00$ a $\mathrm{R} \$ 10,00$, de acordo com os equipamentos disponibilizados, como o rádio, por exemplo.

Em 19 centrais, ou seja, em 54\% das centrais entrevistadas, o proprietário também é mototaxista. Nas centrais maiores 
com mais de 20 mototaxistas os proprietários se dedicam apenas à administração da Central.

Em uma das centrais encontramos uma forma totalmente diversa dessa organização predominante, pois os mototaxistas eram todos assalariados com o devido registro em carteira e jornada de 6 horas diárias em cinco dias da semana. As motos pertenciam aos donos da central que também determinavam o ritmo da atividade, procurando otimizar os trajetos e o uso do combustível.

Em $49 \%$ das centrais o início das atividades se deu há mais de 08 anos, portanto praticamente coincidem com o inicio da atividade na cidade. Na quase totalidade das centrais ocorre o pagamento de aluguel. Essa despesa é, em geral, inferior aos gastos com telefone que se constitui numa das maiores despesas no orçamento dessas pequenas empresas. Quanto aos clientes, o transporte de passageiros é fundamental na sobrevivência da atividade, embora a importância da prestação de serviços a empresas e particulares seja crescente.

Considerando o total das centrais visitadas identificamos a criação de 46 postos de trabalho para funcionários que trabalham como secretários (as) das centrais, dos quais $60 \%$ sem carteira assinada. Quanto ao número de mototaxistas as centrais visitadas reúnem um total de 537 trabalhadores autônomos.

As centrais variam muito em relação ao porte. Consideramos dois critérios nessa classificação: o número de mototaxistas e o numero de viagens diárias. As menores centrais possuem apenas 05 mototaxistas e realizam uma média de 30 corridas por dia e se localizam nas zonas sul e leste da cidade. As duas maiores possuem 40 e 55 mototaxistas, realizam mais de 100 corridas diárias. Localizam-se na área central. 
Mapa 12

Londrina: porte das Centrais por $n .^{\circ}$ de mototaxistas, 2008

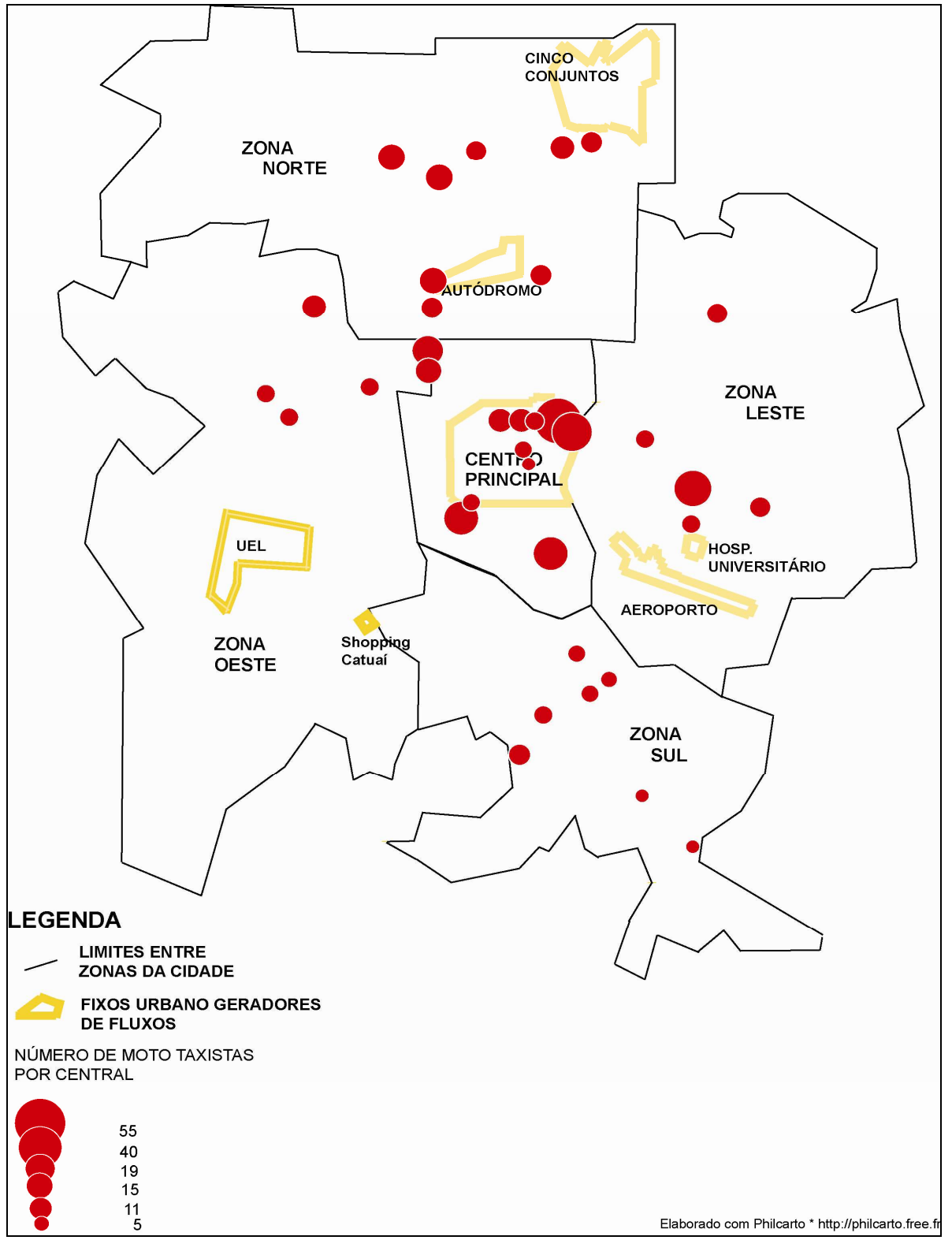

Fonte: Trabalho de Campo, 2008

Em todas as centrais o transporte de passageiros é parte importantes das corridas diárias. Até mesmo naquelas centrais em que os entrevistados declararam que o atendimento a empresas respondia pela maior parte das corridas solicitas à central, o transporte de passageiros correspondia a no mínimo $40 \%$ das corridas. Em 2008, o menor valor cobrado por corrida era de $\mathrm{R} \$ 4,00$, praticado principalmente por centrais 
novas situadas na periferia que lutavam por construir sua clientela. Esse valor de $\mathrm{R} \$ 4,00$ se devia, portanto, a disputas entre as centrais.

Nas centrais mais antigas e estruturadas, o valor mínimo era de $\mathrm{R} \$ 6,00$, considerado como o mínimo necessário para atender a todas as exigências da Prefeitura e da legislação vigente. O valor de $R \$$ 5,00 era divulgado como "promocional" por parte de algumas centrais, próximas às que praticavam o valor de $\mathrm{R} \$ 4,00$, como forma de "enfrentar a concorrência desleal".

A imensa maioria das corridas solicitadas às centrais localizadas nos bairros se destina à área central da cidade. Naquelas situadas no Centro Principal, muitas corridas também têm como destino a própria área central da cidade. São solicitações para ir a bancos, órgãos públicos, cartórios, escritórios de advocacia, consultórios, hospitais que também localizados na área central. Porém, no caso dessas centrais há ainda um número considerável de viagens, cerca de $55 \%$ do total médio de corridas por dia, que têm como destino os bairros, especialmente os Cinco Conjuntos na Zona Norte, o Shopping Catuaí, as Universidades e Hospitais da cidade.

Ao longo de pouco mais de uma década de existência o serviço de Moto Táxi em Londrina se espalhou e se enraizou em todas as partes da cidade. No início de 2008, quando finalizamos a pesquisa de campo sobre essa atividade, havia em Londrina mais de 750 mototaxistas $^{127}$ e aproximadamente 50 centrais de Moto Taxi. Considerando as flutuações e aqueles que ainda não regularizaram sua atividade junto ao órgão oficial, o número de mototaxistas em Londrina alcança facilmente a casa dos 1.000 trabalhadores.

\footnotetext{
${ }^{127}$ Segundo dados da Companhia Municipal de Trânsito e Urbanismo (CMTU) havia em Londrina no inicio de 2008750 mototaxistas cadastrados naquele órgão. Em nossa pesquisa verificamos que há um fluxo constante de entrada e de saída de pessoas na atividade e que o número real de mototaxistas trabalhando é superior ao de cadastrados na CMTU. Muitos trabalhadores têm dificuldades em apresentar de imediato e de uma só vez todos os requisitos exigidos para regularização, especialmente em relação ao Certificado de Registro do Veículo (CRV). Com isso o processo de obtenção do alvará pode levar algum tempo, o que não impede esses trabalhadores de dar entrada no pedido de alvará e começar a atuar.
} 


\section{4 - Entregas Urbanas: empresas e motoboys}

Segundo dados da Federação Nacional dos Motoboys e Mototaxistas (FENAMOTO), circulam no Brasil, aproximadamente dois milhões de motoboys ${ }^{128}$. Os motoboys se multiplicaram por todo país nos últimos 20 anos, acompanhando a dinâmica da urbanização brasileira e a intensificação da circulação intra-urbana. Presentes nos mais diversos tipos de empresas esses trabalhadores garantem a circulação ágil de mercadorias de pequeno volume, documentos e informações, materializando fluxos e reduzindo os constrangimentos da distância e dos entraves do trânsito urbano.

Ser proprietário da moto, principal instrumento de trabalho, é condição básica para que a maior parte dos motoboys consiga exercer essa profissão. Em Londrina, constatamos a existência tanto de motoboys que trabalham como autônomos, como a de motoboys que são assalariados contratados por empresas de entregas urbanas. Esta última forma de atuação foi a mais freqüente entre os motoboys que responderam aos questionários.

Atualmente em Londrina existem pouco mais de uma dezena de empresas de entregas urbanas ${ }^{129}$. No entanto, a maior parte delas é de diminutas dimensões. Algumas se reduzem apenas a três ou quatro pessoas que, juntas, atendem às solicitações esporádicas de

\footnotetext{
128 O presidente da Federação Nacional dos Motoboys e Mototaxistas (FENAMOTO) que defendeu a aprovação do Projeto de Lei 6302/02 em audiência pública na Comissão de Transportes e Viação da Câmara Federal "afirmou que o serviço é regulamentado em cerca de 3.500 municípios e que, em todo o País, dois milhões de pessoas atuam como motoboys e outros 800 mil como moto-taxistas." (SINDICATO DOS MOTOCICLISTAS PROFISSIONAIS DO RS, 2009. grifo nosso)

Ainda sobre o número de motoboys no país, o sítio do Jornal O Estado de São Paulo dá a seguinte informação: "Segundo o relator da proposta, senador Expedito Júnior (PR-RO), existem atualmente no Brasil cerca de 2,5 milhões de motoboys e mototaxistas, que trabalham na completa informalidade." (AGÊNCIA ESTADO, [2009?], grifo nosso).

${ }^{129}$ A base dessa informação foi um levantamento nas listas telefônicas da cidade em meados de 2008. Nesse levantamento feito nas paginas amarelas e nas listas disponíveis na internet encontramos 14 empresas: Ciclo Motoboys, Coiote Entregas Rápidas Ltda, Entregas Rápidas, Linexpress, Pacto entregas, Robson W Magro, RP Central de Entregas e Telecomunicações, Sol Motoboys, Tele Entregas Rápidas, Terceiriza, Transmoto, Vai e Vem Entregas Rápidas, Via Rápida Express e Vinícius Damião Munhoz. Entre setembro e outubro de 2008, entrevistamos os proprietários das três maiores empresas de entrega urbana de Londrina em número de empregados: Vai Vem, Sol Motoboys e Terceiriza. Sobre as demais empresas obtivemos apenas algumas informações gerais
} 
clientes conquistados na base do contato pessoal e da confiança. Por vezes, as sedes dessas empresas são as residências dos proprietários e não há qualquer estrutura administrativa.

Não há informações consistentes sobre o número total de motoboys na cidade, mas, segundo considerações dos três proprietários das empresas de entregas urbanas entrevistados, esse número, em 2008, pode ser estimado como algo que se enquadra na faixa de 1000 a 1300 trabalhadores.

Segundo o proprietário da Vai-Vem, a maior empresa de entregas urbanas da cidade, o ramo é relativamente novo em Londrina, tem aproximadamente entre 10 e 11 anos e, nesse período, muitas empresas fecharam e outras encolheram drasticamente. A instabilidade e a concorrência parecem ter afetado duramente a sobrevivência desse tipo de empresa.

As empresas maiores como a Sol Motoboys, Vai e Vem, Terceiriza, Tele Entregas e a Transmoto funcionam em locais definidos onde alguns motoboys se reúnem diariamente para receber instruções sobre as entregas que irão fazer, para atender alguma chamada de urgência ou para cobrir as faltas de colegas alocados em algum cliente. Essas empresas estão situadas na área central da cidade.

Para poder funcionar satisfatoriamente as empresas elencadas no parágrafo anterior tem que contar com certo grau de organização interna. As tarefas administrativas não ficam todas por conta do proprietário que se dedica ao contato com os clientes, às negociações dos contratos, às decisões sobre contratação de novos entregadores. Há funcionários encarregados de receber as solicitações de clientes, estabelecer rotas para os entregadores, determinar as substituições dos faltosos, controlar os gastos com combustível, as ajudas de custo e a administração de pessoal. 
Tabela 2

Caracterização das três maiores empresas de entrega urbana de Londrina, 2008.

\begin{tabular}{|c|c|c|}
\hline \multirow{2}{*}{ Empresas } & \multicolumn{2}{|c|}{ N.o de funcionários } \\
\cline { 2 - 3 } & Administrativos & Entregadores \\
\hline $\begin{array}{c}\text { Vai e Vem Entregas } \\
\text { Rápidas }\end{array}$ & 7 & 68 \\
\hline Sol Motoboys & 5 & 56 \\
\hline Terceiriza & 5 & 35 \\
\hline
\end{tabular}

Fonte: Trabalho de campo, 2008.

As empresas de entregas urbanas atendem exclusivamente outras empresas e instituições da cidade. A lista é diversificada e abrange empresas com as mais variadas necessidades em relação à circulação intra-urbana. São empresas que necessitam fazer circular documentos, contratos, convites ou outras formas de divulgação de eventos, a exemplo de cartórios, bancos, agências de publicidade, seguradoras, financeiras, escolas, hotéis. Outras empresas, como laboratórios e consultórios de dentistas, necessitam adquirir materiais específicos ou coletar amostras para exames clínicos. Há ainda necessidades mais comuns com as de restaurantes que entregam marmitas, farmácias, pizzarias, lojas de autopeças, entre outras ${ }^{130}$.

As empresas de entregas urbanas possibilitam economia de custos para as empresas que as contratam, colocando-se assim em relação de terceirização que retira da empresa cliente as tarefas relativas à distribuição de documentos, informações e mercadorias. Essa estratégia também atua na redução potencial do tempo de rotação de mercadorias e serviços. Ao assumir a forma de serviço contratado, a gestão das faltas de entregadores e outras situações imprevistas ficam à cargo das empresas de entregas urbanas que têm de garantir a continuidade do serviço.

Apesar de não se caracterizarem como empresas em que predomina o trabalho familiar e de haver certos níveis hierárquicos internos, indicando uma incipiente organização burocrática, as empresas

\footnotetext{
${ }^{130}$ Voltaremos a esse tema no capítulo cinco
} 
de entregas urbanas são, essencialmente, intermediadoras de força de trabalho para tarefas próprias à circulação intra-urbana.

Não dependem da aquisição de volumes consideráveis de capital constante para atuarem como intermediárias na contratação de trabalhadores, muito pelo contrário, tirando certas precauções como as que envolvem a segurança dos locais onde funcionam, essas empresas não requerem muito mais que alguns computadores, telefone e outros equipamentos comuns de escritório para funcionar bem.

As motocicletas, as quais constituiriam a parte do capital que exige maior desembolso, devem ser providenciadas pelo próprio trabalhador. As empresas possuem algumas motos e outros veículos, como automóveis chamados de utilitários, que são adaptados para entregas de volumes um pouco maiores. Esses veículos e motos são para usos esporádicos e para cobrir situações imprevistas, como no caso de panes repentinas nas motos dos entregadores ou solicitações de entregas que fogem ao cotidiano dos contratos e das solicitações das empresas clientes.

De um modo geral queremos dizer que o fator principal da ação das empresas de entregas urbanas é o trabalho árduo e extenuante dos entregadores, ou seja, essas empresas atuam fundamentalmente como fornecedoras de mão de obra. Além disso, têm uma forte dependência do mercado local. Como em Londrina convivem empresas de diferentes tipos, tamanhos e composições orgânicas de capital, as quais solicitam os serviços das empresas de entrega urbana, constatamos que clientela das entregadoras pertence tanto ao circuito superior, como ao circuito superior marginal e até ao circuito inferior. As entregadoras têm como clientes, desde multinacionais até pequenas escolas, videolocadoras, entre outras.

Esses critérios nos levam a considerá-las, no caso das três maiores entregadoras, como empresas situadas entre o circuito superior marginal e o circuito inferior da economia urbana. 


\section{CAPÍtTULO 5}

\section{Trabalho, pobreza e circuito inferior no período atual}

\section{1 - Transformações no mundo do trabalho e a dinâmica do empobrecimento relativo}

Em Londrina, a formação e a estruturação das atividades do circuito inferior analisadas neste trabalho são, para os trabalhadores diretamente envolvidos, meios de luta para minimizar os efeitos danosos da instabilidade e da precarização a que se vêem submetidos. Em países como o Brasil a sobrevivência é, naturalmente, parte substancial desse esforço, entretanto não esgota seu significado; uma existência mais digna se coloca como um horizonte possível. Esta busca remete à questão da pobreza e dos pobres urbanos no período atual.

A situação de pobreza, e sua dinâmica histórica em países subdesenvolvidos, é um dos motores do florescimento e das transformações do circuito inferior, que por sua vez, possui, com a pobreza, uma relação complexa: o circuito inferior é simultaneamente um "perpetuador da pobreza" (SANTOS, 1979), e a possibilidade que se coloca para os pobres urbanos de reduzir a insegurança, a precariedade e a exclusão. Logo, a caracterização da pobreza no período atual pode ser revelada pelo circuito inferior

En el período actual, el circuito inferior revela la existencia de una pobreza estructural, es decir, no marginal u ocasional sino una "producción científica, globalizada y voluntaria de la pobreza" (SANTOS, 200:72). En otras palabras, hoy el empleo y el salario se reducen por la creciente racionalización de la sociedad y del territorio. [...]En la medida en que ese proceso de racionalización se globaliza, también lo hacen sus consecuencias y sus productos, como la pobreza. Si en el discurso es considerada como un hecho indeseable, en la práctica la pobreza es necesaria al funcionamiento de un sistema regido por nexos financieros (SILVEIRA, 2008, p.1476).

O processo de racionalização da sociedade e do território sublinhado por Maria Laura Silveira (2008) é, como nos diz a própria 
autora, orientado pela busca da competitividade e se expressa na difusão de sistemas técnicos automatizados e na adoção de normas destinadas a substituir ou reduzir o trabalho humano. Além do desemprego crônico que resulta da substituição ou redução do trabalho humano, outro resultado que contribui para ampliação da pobreza é o processo precarização do trabalho.

O processo de precarização percorre algumas das áreas de emprego estabilizadas há muito tempo. Novo crescimento dessa vulnerabilidade de massa que, como se viu, havia sido lentamente afastada. Não há nada de "marginal" nessa dinâmica. Assim como o pauperismo do século XIX estava inserido no coração da dinâmica da primeira industrialização, também a precarização do trabalho é um processo central, comandado pelas novas exigências tecnológico-econômicas da evolução do capitalismo moderno. (CASTEL, 1998, p.526)

A precarização se expressa na intermitência do trabalho, na perda de direitos, na seguridade social restrita e na intensificação do trabalho por vezes associada a condições insalubres e perigosas. A profundidade das transformações trazidas pelo desemprego e pela precarização a partir dos anos 1990 deve ser avaliada levando-se em conta que, no Brasil, houve um processo restrito de fixação dos trabalhadores na chamada sociedade salarial ${ }^{131}$ (LAUTIER, 1987).

No contexto da sociedade salarial a relação salarial não é apenas retribuição a uma tarefa, ela assegura o acesso a "subvenções extratrabalho (doenças, acidentes, aposentadoria) e permite uma participação ampliada na vida social: consumo, habitação, instrução e até mesmo, a partir de 1936, lazer" (CASTEL 1998, p.416). No Brasil o desenvolvimento das forças produtivas, no âmbito do processo de industrialização tardia, promoveu o assalariamento que, entre 1940 e 1980 tornou-se o principal vínculo de trabalho.

\footnotetext{
131 "De certa forma, toda vez que a população trabalhadora parecia ganhar força (e maioria no legislativo ou no executivo), o autoritarismo foi sistematicamente utilizado pelos interesses econômicos e políticos contrários a esse movimento, a fim de bloquear as brechas de avanços sociais possíveis. [...]

Nessas condições, o projeto de sociedade salarial não se completou, e o mercado de trabalho funcionou com enorme excedente de mão-de-obra e diversas formas de ocupações não-assalariadas, precárias e marginalizadas do sistema de proteção social no interior do mercado de trabalho. Mesmo com a ampliação considerável do assalariamento no Brasil, que passou de aproximadamente um quinto do total dos ocupados no fim da década de 1930 para cerca de dois terços em 1980, o mercado de trabalho manteve-se extremamente heterogêneo." (POCHMANN, 2008, p.119)
} 
Ainda que incompleta, a tendência de estruturação do mercado de trabalho se deu em função da rápida ampliação dos empregos assalariados, sobretudo daqueles com registros formais, da redução relativa das ocupações por conta própria e sem remuneração e do desemprego.

A comparação entre os anos 1940 e 1980 permite observar que, para cada 10 ocupações geradas, 8 foram assalariadas, sendo 7 com contrato formal e uma sem contrato.

As ocupações por conta própria, dos trabalhadores sem remuneração e dos empregadores representaram apenas $20 \%$ do total dos postos de trabalho criados no mesmo período. Assim, a taxa de assalariamento no Brasil foi de $66 \%$ do total das ocupações, enquanto na década de 1930 não ultrapassava os 20\%. (POCHMANN, 2004, p.24)

A difusão da relação salarial abarcou diversos tipos de trabalhadores, tornando-se um fator de redução da heterogeneidade no interior da divisão do trabalho e de disseminação da expectativa de vínculos de trabalho duradouros ${ }^{132}$. Porém, com o advento da reestruturação produtiva e da acumulação flexível, conceitos empregados para designar o conjunto de transformações que interrompeu a trajetória de construção da sociedade salarial no Brasil e em diversos outros países na década de 1990, os vínculos de trabalho se tornaram instáveis.

Na América Latina e, especialmente no Brasil, a partir dos anos 1980, há uma intensa redefinição do processo de reprodução social que até então se assentava no emprego como um dado fundamental do padrão de integração social. A reestruturação neoliberal dos anos 1990 impôs uma racionalidade pautada na elevação do nível de competitividade das economias nacionais e na redefinição da atuação do Estado.

Feita a reestruturação nos países centrais, ainda que de maneira incompleta, as Empresas Transnacionais ${ }^{133}$ necessitavam agora reestruturar seus sistemas na periferia. Para isso, porém, se defrontavam com Estados nacionais soberanos, que poderiam obstaculizar seus intentos e contavam com um poder maior, o de seus próprios Estados nacionais ou blocos, como a CEE, por exemplo. [...]

Para atingir seus objetivos, os países centrais impuseram aos países devedores as chamadas políticas neoliberais, transplantando para periferia um conjunto de mudanças institucionais, produtivas, comerciais e financeiras, como as que já

\footnotetext{
132 “A consolidação da condição salarial, como já foi sublinhado, deveu-se ao fato de que assalariar um pessoa tinha, cada vez mais, consistido em prender sua disponibilidade e suas competências a longo prazo - isto contra uma concepção mais rude da condição de assalariado que consistia em alugar um indivíduo para executar uma tarefa pontual." (CASTEL, 1998, p.517)

${ }^{133}$ Substituímos a sigla ETs, originalmente utilizada pelo autor, por "Empresas Transnacionais"
} 
haviam implantado em seus próprios países, e que consistiam, resumidamente, em diminuição do papel do Estado, privatizações, desregulamentações e abertura comercial. O discurso ideológico utilizado para isso foi o de que chegara a hora da periferia modernizar-se, igualando-se ao primeiro mundo. (CANO, 2000, p.32)

A nova onda de modernização propagada a partir das transformações tecnológicas e da vigência do modelo neoliberal produziu efeitos devastadores sobre o mercado de trabalho formal, com implicações sobre o processo de empobrecimento. O economista Marcio Pochmann (1999, p.17) afirma que a difusão de inovações tecnológicas e organizacionais implantadas em um cenário de baixas taxas de crescimento gerou maior heterogeneidade social. Essa heterogeneidade pode ser identificada pela instabilidade dos vínculos e pela precarização das condições de trabalho, associadas às elevadas taxas de desemprego.

Em síntese, o mercado de trabalho após 1980, registrou o
agravamento da pobreza e da indigência. Isto representa uma
rápida inversão da tendência verificada entre $1950 / 80$ quando
gradualmente foi registrada a diminuição dos índices de pobreza
nos meios urbano e rural. As novas formas de exclusão no
mercado de trabalho, com o desemprego aberto, ocupações
atípicas e precarização nas condições e relações de trabalho
complementam o cenário de dificuldades nos países latino-
americanos (POCHMANN, 1999, p. 54,55$)$.

A relação entre desemprego, precarização e expansão da pobreza passa pelo fato de que, na América Latina, para a grande maioria das famílias, os rendimentos provêm exclusivamente do trabalho, seja na forma de emprego, seja na forma de alguma outra ocupação (SALAMA, 1999, p.28). No Brasil, as transformações impostas pelas políticas neoliberais redundaram em forte redução da participação do trabalho na renda nacional. Os rendimentos oriundos do trabalho que representavam $50 \%$ da renda nacional em 1980 passaram para 36\% em 2002 (POCHMANN, 2004, p.30).

Com o aumento acelerado do desemprego na década de 1990, além da perda da principal fonte de renda para muitos trabalhadores, houve queda na renda média dos trabalhadores brasileiros 
que estavam empregados. Apesar de alguma recuperação os patamares atuais ainda estão abaixo do que alcançaram há dez anos.

Gráfico 15

Brasil: variação do rendimento médio real dos assalariados em seis regiões metropolitanas, 1998 a 2008 (em reais de 2008)

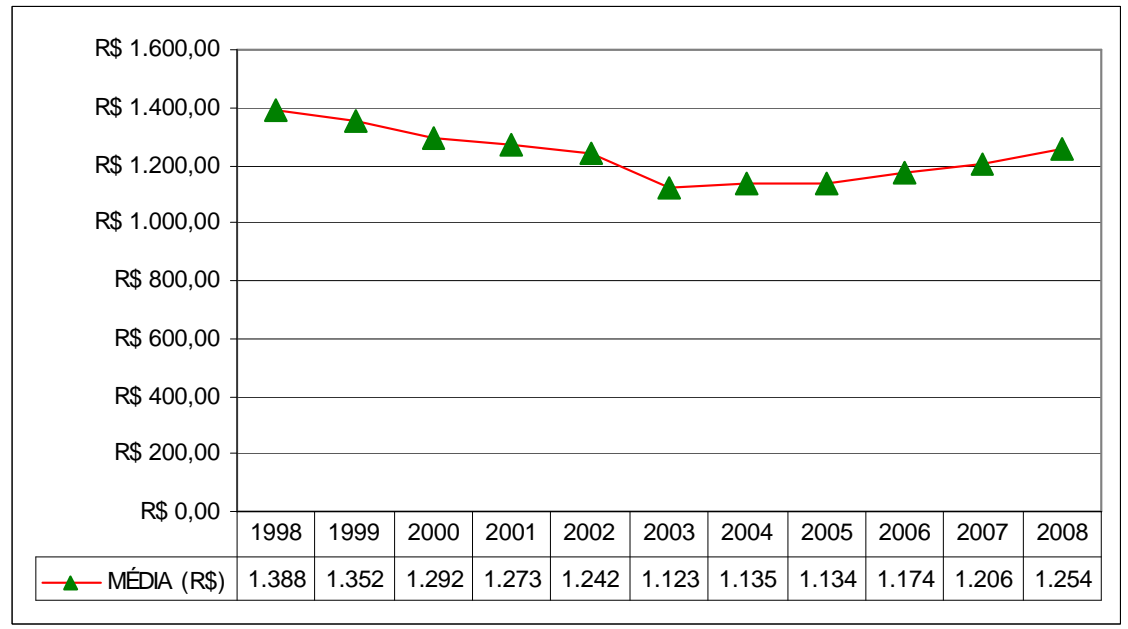

Fonte: PESQUISA EMPREGO E DESEMPREGO, 1984-.

Gráfico 16

Brasil: pessoas em domicílios abaixo da linha da pobreza, 1977 a 2007 (milhões)

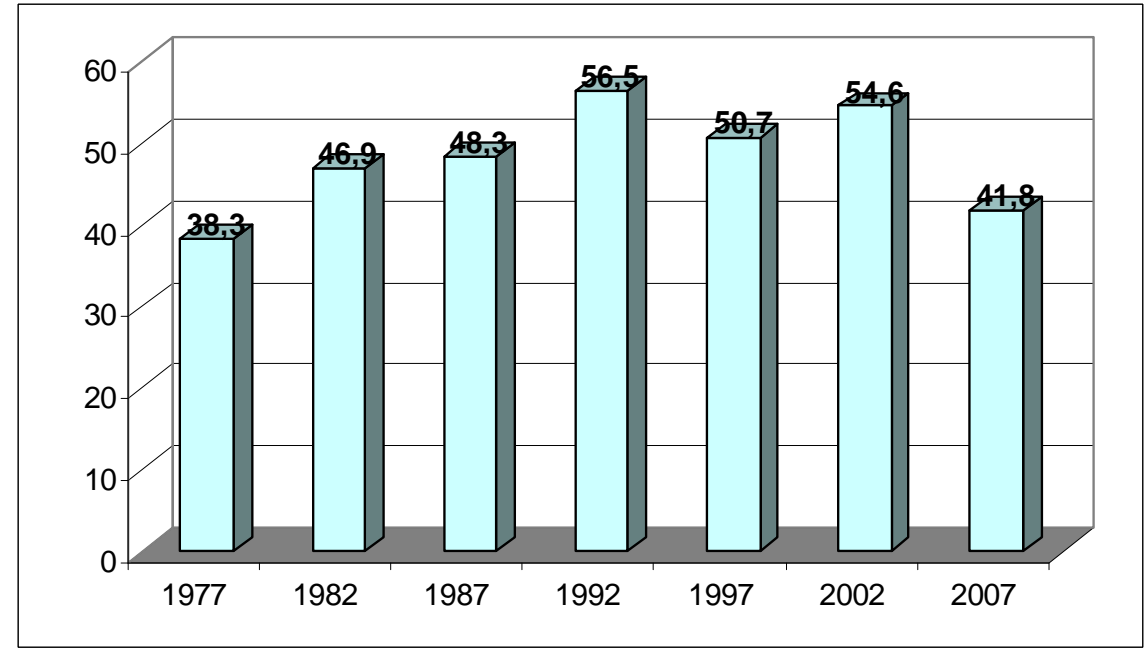

Fonte: FUNDAÇÃO GETÚLIO VARGAS, 1960-.

As considerações e avaliações sobre o número de pessoas pobres e a dinâmica do empobrecimento são importantes, pois indicam a tendência de aumento ou redução global da pobreza. Todavia, é preciso ressaltar que, geralmente, essas avaliações partem de critérios 
quantitativos e estatísticos como o número de pessoas que vivem com ganhos da ordem de um ou dois dólares por dia. O empobrecimento relativo fica assim escamoteado pela alarmante expansão da miséria e dos números absolutos da pobreza.

Para Milton Santos (2008, p.59) "ser pobre não é apenas ganhar menos do que uma soma arbitrariamente fixada; ser pobre é participar de uma situação estrutural, com uma posição relativa inferior dentro da sociedade como um todo". O autor arremata dizendo que essa condição, a de empobrecimento relativo, atinge um número cada vez maior de pessoas. Há que distinguir também entre os miseráveis e pobres.

O exame do papel dos pobres na produção do presente e do futuro exige, em primeiro lugar, distinguir entre pobreza e miséria. A miséria acaba por ser a privação total, com o aniquilamento, ou quase, da pessoa. A pobreza é uma situação de carência, mas também de luta, um estado vivo, de vida ativa, em que a tomada de consciência é possível. (SANTOS, 2008 p.132)

Segundo Amartya Sen (2000, p.110), para se tornar realmente heurístico, o conceito de pobreza deve ser interpretado como privação de capacidades, ampliando assim seu alcance para além da ligação umbilical entre pobreza e baixa renda. Dessa forma, outras condições como idade, papéis sexuais e até a localização poderiam atenuar ou intensificar a condição de pobreza de um grupo. Analisando o desemprego como fator ligado à pobreza até mesmo em sociedades afluentes o autor nos diz:

A presença de níveis elevados de desemprego na Europa (cerca de 10 a $12 \%$ em muitos dos principais países europeus) implica privações que não são bem refletidas pelas estatísticas de distribuição de renda. Com freqüência se tenta fazer com que essas privações pareçam menos graves, argumentando que 0 sistema europeu de seguridade social (incluindo o segurodesemprego) tende a compensar a perda de renda dos desempregados. Mas o desemprego não é uma deficiência de renda que pode ser compensada por transferências do Estado (a um pesado custo fiscal que pode ser, ele próprio, um ônus gravíssimo); é também uma fonte de efeitos debilitadores muito abrangentes sobre a liberdade, a iniciativa e as habilidades dos indivíduos. (SEN, 2000, p.35) 
As argumentações de Amartya Sen e Milton Santos sobre o empobrecimento relativo permitem perceber com mais clareza como o desemprego pode afetar não apenas a renda dos trabalhadores, mas de acordo com sua idade, por exemplo, pode afetar suas possibilidades quanto ao futuro e disparar formas de luta criativas ou conformismo. A flexibilidade tropical pode ser um indicador de como racionalidades que não se coadunam com a racionalidade hegemônica podem, a partir da cidade, aflorar e produzir a esperança.

As atenções do mundo acadêmico foram guindadas pela efervescente e ruidosa manifestação da acumulação flexível e da flexibilização das relações de trabalho. Sua incidência sobre contextos e conjunturas particulares, a exemplo de países subdesenvolvidos e industrializados como o Brasil, no entanto, não parece ter tido a mesma sorte. Menos ainda a análise do meio urbano como fator de resistência e de viabilização de alternativas.

David Harvey aponta que, no interior da "acumulação flexível $^{134 "}$ o mercado de trabalho conhece uma profunda reestruturação tornando-se volátil. A expressão dessa volatilidade é, sobretudo, a "aparente redução do emprego regular em favor do crescente uso do trabalho em tempo parcial, temporário ou subcontratado" (HARVEY, 1992, p.143). Trata-se da flexibilização das relações de trabalho, expressão geralmente empregada para enfatizar a ruptura dos padrões de normatização das relações trabalhistas ligados aos contratos coletivos sem prazo determinado, que predominaram como normas pactuadas das relações entre capital e trabalho nos países centrais, no período entre os anos 1950 e meados dos anos 1980.

\footnotetext{
134 "A acumulação flexivel, como vou chamá-la, é marcada por um confronto direto com a rigidez do fordismo. Ela se apóia na flexibilidade dos processos de trabalho, dos mercados de trabalho, dos produtos e padrões de consumo. Caracteriza-se pelo surgimento de setores de produção inteiramente novos, novas maneiras de fornecimento de serviços financeiros, novos mercados e, sobretudo, taxas altamente intensificadas de inovação comercial, tecnológica e organizacional. A acumulação flexível envolve rápidas mudanças de padrões do desenvolvimento desigual, tanto entre setores como entre regiões geográficas, criando, por exemplo, um vasto movimento no emprego no chamado "setor de serviços", bem como conjuntos industriais completamente novos em regiões até então subdesenvolvidas[...] Ela também envolve um novo movimento que chamarei de "compressão espaço-tempo" no mundo capitalista [...]" (HARVEY, 1992, p. 140)
} 
No contexto da reestruturação produtiva dos anos 1990, Robert Castel (1998, p.517) distingue, na relação capital-trabalho, a flexibilidade interna da flexibilidade externa. A flexibilidade interna está ligada à necessidade de treinar o pessoal contratado diretamente pela empresa, criando trabalhadores polivalentes capazes de enfrentar as novas situações que, a todo o momento, surgem no processo de trabalho em razão de sua ligação mais estreita com a esfera do consumo. A flexibilidade externa seria exemplificada pela subcontratação, terceirização, etc. Tanto num como noutro caso, ocorre a eliminação dos que são considerados incapazes de se adaptar as novas demandas impostas pelas novas tecnologias e formas de organização.

Ampliando seu comentário sobre a flexibilidade interna Robert Castel aponta conseqüências para os mais jovens e para os que estão envelhecendo:

\begin{abstract}
Quando, no contexto da busca da "flexibilidade interna", a empresa entende adaptar as qualificações dos trabalhadores às transformações tecnológicas, a formação permanente pode funcionar como uma seleção permanente.

O resultado é a invalidação dos "trabalhadores que estão envelhecendo", demasiado idosos ou não suficientemente formados para serem reciclados, mas jovens demais para se beneficiarem da aposentadoria. [...]

Mas a empresa falha igualmente em sua função integradora em relação aos jovens. Elevando o nível das qualificações exigidas para a admissão, ela desmonetariza uma força de trabalho antes mesmo que tenha começado a servir. Assim jovens que há vinte anos teriam sido integrados sem problemas à produção acham-se condenados a vagar de estágio em estágio ou de um pequeno serviço a outro. (CASTEL, 1998, p.519)
\end{abstract}

Cabe indagarmos: os lugares onde esses processos ocorrem não contribuem para torná-los diversos, produzindo modificações em suas estruturas?

Milton Santos (1994, p.79) ao discutir sobre como a cidade resiste aos produtos da racionalidade hegemônica, a exemplo da flexibilização dos vínculos de trabalho, do desemprego e da precarização, sugere não perder de vista "flexibilidade tropical" que nas grandes cidades do Terceiro Mundo atenua a crise. Usando de certa ironia, Milton Santos aponta que, dada a diversidade do meio construído nas grandes cidades, 
especialmente a existência de áreas desvalorizadas, abre-se a possibilidade de que as pessoas participem da dinâmica da divisão do trabalho, criando inserções que lhes permitem resistir às conseqüências da racionalidade hegemônica.

Nesse sentido, de forma combinada, ocorre a tendência de expansão da racionalidade hegemônica, especialmente a desvalorização do trabalho, e a tendência de expansão do circuito inferior da economia urbana. Além disso, a expansão, ou reestruturação do circuito inferior, é movida também pelo crescimento da heterogeneidade social e pelas novas formas de escassez que atingem também as classes médias.

No Brasil, a flexibilização das relações de trabalho aprofunda um problema que já existia de forma crônica: a rotatividade da mão de obra. No período atual ocorre a intensificação da volatilidade dos vínculos de trabalho, inclusive para setores que haviam atingido certa estabilidade, alguns deles, redutos da classe média ${ }^{135}$. Com a volatilidade dos vínculos de trabalho, inerente ao processo de racionalização da sociedade e do território, a heterogeneidade social se aprofunda, tornando-se mais complexa e mais ligada à emergência de novos processos de empobrecimento. Para Cecília Cariola e Miguel Lacabana, em face das transformações aceleradas no mundo do trabalho, a pobreza se tornou mais heterogênea e se difundiu na sociedade.

A fines de la década de los noventa nos encontramos frente a
nuevos fenómenos sociales que van más allá de la pobreza
estructural. La pobreza se extendió a sectores medios con otra
cara, o más bien sin cara, en una forma poco visible, escondida en
el ámbito doméstico y diluida territorialmente en diversas áreas de
la ciudad. [...]
Pobreza estructural y nueva pobreza tienen algunos rasgos en
común, y los sujetos inmersos en estas situaciones desarrollan
algunas relaciones y prácticas similares, pero constituyen
fenómenos sociales cualitativamente distintos que alcanzan a

135 São transformações que ocorreram nas grandes empresas privadas tais como: a terceirização, a redução de postos intermediários de chefia e coordenação decorrentes da adoção de novas tecnologias e de novas formas de gestão e organização da produção. A formação de redes de empresas por meio da subcontratação multiplicou as formas de uso indireto de mão-de-obra, transformando ex-funcionários em autônomos, consultores, prestadores de serviços, etc. Processos semelhantes ocorreram no âmbito do setor público com as privatizações de estatais e a contratação de pessoal terceirizado com contratos de trabalho por tempo definido para serviços prestados por órgãos públicos. 
grupos sociales diferentes y diversos. Mientras los sectores populares tendieron a estancarse dentro de la zona de exclusión y profundizaron sus condiciones de pobreza estructural diferenciando grupos que van desde la pobreza extrema a la moderada, los sectores medios transitaron por distintos niveles de vulnerabilidad asociados a los diversos procesos de exclusión o de inclusión parcial.

Los sectores medios de nuevos pobres han compartido con los pobres estructurales el deterioro de sus condiciones de empleo e ingresos y desarrollaron prácticas adaptativas similares para enfrentarlo, como las referidas a la incorporación extensiva al mercado de trabajo, la generación de autoempleo, la reorganización doméstica y el ajuste del consumo. (CARIOLA e LACABANA, 2004)

As classes médias brasileiras acostumadas a desfrutar das melhores oportunidades de trabalho e a participar com certo grau de exclusividade das possibilidades de consumo abertas pelo milagre econômico dos anos 1970, viram-se de forma mais ou menos repentina no meio do turbilhão. O empobrecimento e a experiência da escassez batem as portas da classe média (SANTOS, 2008, p.137). Para os pobres a situação se agrava, vivemos um momento em que a pobreza resulta de "um sistema de ação deliberada" e se deve tanto a "expansão do desemprego" quanto à "redução do valor do trabalho" (SANTOS, 2008, p.72).

Essas observações nos colocam diante do desafio de analisar tanto as formas de enfrentamento da pobreza que redundam em criação de atividades caracterizadas como trabalho por conta própria quanto à manutenção e criação de empregos formais, isto é, com registro em carteira, mas que são mal remunerados. Em muitos casos, esses empregos são caracterizados por aspectos como jornadas de trabalho extenuantes, resultantes da combinação de ocupações assalariadas com ocupações por conta própria e pela necessidade de os trabalhadores providenciarem seus próprios instrumentos de trabalho.

Para os trabalhadores do circuito inferior os parâmetros e exigências postas para contratação em atividades do circuito superior, quando definidas pelos critérios da flexibilização e da racionalidade hegemônica, transformaram-se em barreiras muito difíceis de transpor. Para um mototaxista, com mais de 35 anos, casado ou divorciado, com 
ensino fundamental completo e que se dedica a atividade há mais de 5 anos não há muitas perspectivas de voltar a participar do chamado mercado formal de trabalho. Parafraseando Robert Castel (1998) diríamos que esse trabalhador enfrenta a invalidação por envelhecimento. É preciso enfatizar que, como alerta o autor, o outro lado dessa invalidação é que o trabalhador ainda não pode se aposentar. Uma das conseqüências disso é que, em geral, a possibilidade de conseguir uma aposentadoria por suas próprias contribuições fica indefinidamente adiada pelas urgências do cotidiano ${ }^{136}$.

Um motoboy com 23 anos de idade, ensino médio completo cursado em escolas públicas, embora disponha do tão decantado registro em carteira e, teoricamente desfrute de uma condição menos insegura, também não conta com melhores perspectivas quanto ao futuro. Esses jovens enfrentam um nível razoável de dificuldade para encontrar um posto de trabalho no mercado formal com remuneração semelhante ou superior à que obtém como entregadores, graças às jornadas de trabalho extenuantes a que se submetem.

Para complicar um pouco mais a volatilidade os persegue como uma sombra. Como motoboys, a manutenção de sua "empregabilidade" depende da possibilidade de trocar periodicamente, às suas expensas, a motocicleta usada por outra mais nova. Esses aspectos particulares iluminam, de certo modo, a heterogeneidade que resulta do processo de empobrecimento apontada por Cariola e Lacabana (2004).

\footnotetext{
${ }^{136}$ Foi possível verificar durante o trabalho de campo que $75 \%$ dos mototaxistas entrevistados não recolhiam regularmente as taxas necessárias para manter o registro como contribuinte da Previdência, apenas $25 \%$, isto é, 19 entrevistados recolham essas taxas regularmente.
} 


\section{2 - Formas de resistência e enfrentamento da pobreza no período atual: a diversidade de abordagens}

No período atual, a resistência ao empobrecimento e ao sofrimento humano decorrentes da crise do assalariamento e do chamado setor organizado do mercado de trabalho, produz novas formas de criar ocupações e gerar renda e reafirma antigas. Acompanhando essa dinâmica convivem novas e antigas abordagens.

Algumas digressões sobre essas abordagens se fazem necessárias para situar a teoria dos circuitos no contexto dos debates sobre as formas de enfretamento desse período de crise que afeta duramente a dinâmica da reprodução social.

As abordagens sobre o setor informal, por exemplo, conhecem um renovado vigor e interesse. O conceito de setor informal teve sua origem nos anos 1970, no âmbito da Organização Internacional do Trabalho (OIT). Um marco da elaboração do conceito de setor informal foi o relatório sobre emprego e renda elaborado no Kenya, em 1972, o qual, segundo Cacciamali (1982, p. 12), serviu de base a outras pesquisas semelhantes realizadas na África e na América Latina.

Inicialmente o conceito de setor informal abarcava uma série de atividades urbanas caracterizadas a partir do estabelecimento produtivo. O limite da informalidade era dado pela maneira como a produção era organizada e pela posição relativa da atividade frente ao conjunto das atividades produtivas. Em geral e complementarmente essas atividades eram consideradas como de "baixa produtividade e como atividades que se desenvolviam à margem da legislação e nas franjas do mercado" (THEODORO, 2000, p. 7). Essa perspectiva de análise, construída em uma instituição oficial, a Organização Internacional do Trabalho (OIT), visava a criar condições de intervenção em relação ao problema do subemprego e ao da pobreza. Entendidos como anomalias do processo de desenvolvimento, esses problemas constituíam uma espécie de mau funcionamento local da teoria do desenvolvimento, na medida em que, no 
mesmo período, o processo de industrialização ensejava no Brasil e em outros países da América Latina elevados níveis de crescimento do produto interno bruto. $\mathrm{O}$ autor enfatiza esse aspecto do conceito de setor informal ao dizer que este.

[...] constitui um marco importante, muito menos pela sua capacidade explicativa vis-à-vis à realidade do Terceiro Mundo, mas principalmente por justificar e avalizar uma nova postura institucional face ao problema do subemprego. É a idéia de setor informal que vai servir de base para a ação institucional em termos de políticas de apoio. A abordagem em termos do setor informal é essencialmente uma perspectiva de intervenção institucional, abrindo um novo campo de ação do Estado. As particularidades da noção de setor informal começam na própria forma como se deu sua concepção. Segundo Lautier (1994), tratase de um caso único: um conceito forjado no interior de uma instituição executiva e que a seguir invade os meios acadêmicos. Isso explicaria em parte sua fragilidade teórica, expressa notadamente na dificuldade em se encontrar uma definição universalmente aceita da qual falava Tokman. (THEODORO, 2000, p.7)

Mario Theodoro acrescenta ainda que, apesar de ser um conceito teoricamente frágil, o setor informal se mostrou ideologicamente forte. Ao se difundir, esse conceito permitiu a reunião e a aplicação de recursos consideráveis, a montagem de redes de pesquisadores e instituições de pesquisa etc.(THEODORO, 2000, p. 9).

Cacciamali (1982, p. 17) explica que é preciso reconhecer algumas nuances em relação ao conceito de setor informal, produzidas pelo deslocamento do critério de forma de organização da produção e pela centralidade dada aos critérios de renda e vínculo jurídico.

No âmbito da América Latina, o debate com as outras correntes de interpretação, a exemplo da teoria da marginalidade e da teoria da dependência, que se acercavam do mesmo fenômeno criou condições para que o conceito de setor informal ganhasse outras colorações, tornando-se bastante plural. Cacciamali (1982) sugere que, na América Latina, duas interpretações concorrentes acerca do setor informal se estabeleceram. A primeira, ligada ao Programa de Renda e Emprego para América Latina e Caribe (PREALC) da OIT, considerava que o setor informal abarcava todas as atividades de baixo nível de produtividade, os trabalhadores 
independentes, com exceção feita aos profissionais liberais, e as empresas muito pequenas ou não organizadas.

A novidade ficava por conta da explicação da origem do setor informal, ligada ao padrão capitalista de desenvolvimento na região, fortemente atrelado ao processo de substituição de importações e que gerava poucos empregos. Isso, aliado ao forte crescimento demográfico, criava um elevado excedente de mão-de-obra que se auto-empregava para sobreviver. Permanecia nesse caso uma forte associação entre pobreza-migração-setor informal (CACCIAMALI, 1982, p. 19-20).

O formalismo dessas concepções era em parte contrabalançado pelo fato de alguns expoentes dessa abordagem, como Paulo Renato Souza (1980) e Vitor Tokman (1978), defenderem que o setor formal e o informal participavam de um mesmo mercado, enfatizando que o último se colocaria numa posição hierarquicamente inferior em função da heterogeneidade estrutural da economia capitalista. Embora destacandoIhes as múltiplas ligações, esses autores não deixam dúvidas acerca da separação entre os dois setores e sobre o caráter provisório de muitas atividades do setor informal (atividades marginais). Chegam, assim, a proposições de que apenas as atividades funcionais que compõem o setor informal deveriam receber algum apoio do Estado, uma vez que elas seriam capazes de alguma expansão a curto e médio prazos (SOUZA, 1980).

O contraponto dessas reflexões elaboradas ao longo dos anos 1970 era evidentemente a expansão das relações de produção tipicamente capitalistas, processo tido como inexorável na forma como se apresentava então. O assalariamento aparecia como possível substituto das atividades por conta própria. Nada mais enganoso.

A segunda abordagem apontada por Cacciamali (1982) refere-se a autores do campo marxista. Essa abordagem, denominada pela autora como "subordinada", coloca em pauta a perspectiva da totalidade, na qual qualquer visão dual da realidade deve ser substituída por uma compreensão em que as diferentes manifestações das relações de 
produção não sejam isoladas. Sendo assim, a questão da subordinação aparece como forma de explicar o setor informal, colocando mais peso na explicação das interdependências entre ele e o setor formal.

A caracterização do setor informal passa então a se fazer a partir da ausência da relação assalariada e da não separação entre proprietários dos meios de produção e trabalhadores. Nessa conceituação o setor informal passa a ser composto por trabalhadores por conta própria, unidades de produção com base familiar, ajudantes e empregados ocasionais que trabalham para esses grupos. A subordinação do setor informal ao formal dar-se-ia principalmente pelo acesso restrito do primeiro a matérias-primas, tecnologia, créditos etc.

Essa abordagem trouxe novamente certa centralidade à produção como critério de definição do setor informal. Nesse contexto a existência do setor informal também é tida como precária, pois estaria continuamente submetida à expansão capitalista em suas variadas escalas. O setor informal seria criado, destruído e recriado ao sabor das variações conjunturais dessa expansão.

Os modelos teóricos que sustentam as diferentes abordagens acerca do conceito de setor informal guardam certa semelhança em relação àquilo que desconsideram. Nas duas abordagens identificadas por Cacciamali (1982), a importância da heterogeneidade das atividades classificadas como integrantes do setor informal, a diversidade de relações que elas mantêm entre si e com as atividades tidas como formais e a sua enorme variação em relação aos contextos nacionais e regionais não são consideradas, nem mesmo de forma secundária.

Em alguns casos, as abordagens descritas buscam compreender as atividades extremamente heterogêneas do setor informal a partir de uma perspectiva da totalidade; no entanto, esbarram na necessidade de estabelecer classificações genéricas e abrangentes e abusam de procedimentos de abstração que eliminam a consideração da particularidade, do movimento e da história em nome de uma razão técnica e de comparações internacionais. Dessa forma a pasteurização do 
conceito encaixa-se nas exigências das agências internacionais e atende os requisitos de uma racionalidade voltada à intervenção e ao planejamento. Essa racionalidade busca na generalidade dos conceitos suas bases de sustentação, ainda que concretamente seja bloqueada pela diferença substantiva de significação das formas de interdependência entre os recortes artificiais do formal e do informal no espaço e no tempo.

Outro complicador é a associação imediata entre pobreza e setor informal, tão cara às propostas de políticas estatais de intervenção no mercado de trabalho. O trabalho de Cacciamali (1982) faz críticas veementes a essa associação e procura dar um fundamento mais elaborado ao conceito de setor informal urbano. Estudando a cidade de São Paulo, a autora apresenta argumentos empíricos para demonstrar que as atividades do setor informal podem ser dinâmicas e atendem um público variado, que não se compõe apenas da fração mais pobre da população. Da mesma forma, as atividades que compõem o setor informal não são conduzidas necessariamente por migrantes recém-chegados às grandes cidades, como faziam crer certas versões do conceito de setor informal. As barreiras à entrada e os conhecimentos exigidos para o sucesso dessas atividades indicam que são necessários requisitos que os migrantes e os jovens não poderiam atender.

Por outro lado, no mercado formal de trabalho há inúmeras funções que remuneram de forma muito precária aqueles que as desempenham. Trabalhadores braçais da construção civil, dos serviços de limpeza e ajudantes gerais nas indústrias, por exemplo, foram e são funções mal remuneradas, e, por isso, integram o contingente de pobres presente nos grandes centros urbanos que está associado ao setor formal e não apenas ao setor informal. Com essas contribuições a autora oferece elementos que permitem discutir a separação e a classificação das atividades como parte de setores bem definidos, com destaque para a associação imediata e inconsistente que se faz entre migrantes, pobreza, ilegalidade e setor informal. 
Face à dinâmica recente que as transformações no padrão de uso e remuneração da força de trabalho (POCHMANN, 1999) instauraram nos países latino-americanos, em especial no Brasil, o tema do setor informal voltou à cena com muita força tanto na mídia como nos debates acadêmicos.

Em seu interessante estudo sobre as relações entre o Estado e o setor informal no Brasil, Theodoro (2000, p. 12) aponta que nos anos 1980 o setor informal deixou de ser visto como algo transitório e passou a ser entendido como uma resposta permanente da força de trabalho em relação a sua sobrevivência. Em resumo, nos anos 1980 o debate sobre a intervenção estatal na questão do setor informal passava paulatinamente do status de "questão técnica" para o de "questão social". Segundo Theodoro (2000, p. 14-15), nos anos 1990 o setor informal viria a ser analisado sob a perspectiva neoliberal ou, como ele diz, de forma subsidiária. Nesse contexto, as políticas sociais "focadas" que foram colocadas em prática passaram a destinar, de forma seletiva e numa perspectiva individualista, recursos na forma de microcrédito como forma de apoiar empresários do setor informal.

Alguns autores têm preferido falar em informalidade como um conceito diferente do de setor informal, na medida em que ela seria capaz de abarcar outras especificidades do contexto latino-americano (LAUTIER, 1994). Dessa forma, o conceito de informalidade seria mais abrangente que o de setor informal (MALAGUTI, 2000).

Em texto mais recente, Cacciamali (2000, p. 163) enfatiza o que ela denomina "processo da informalidade", no qual o termo "informal" se refere a um "processo de mudanças estruturais em andamento na sociedade e na economia que incide na redefinição das relações de produção, das formas de inserção dos trabalhadores na produção, dos processos de trabalho e de instituições [...]". Dessa maneira a autora procura uma forma de diferenciar sua abordagem de enfoques reducionistas presentes em estudos que adotam conceitos restritos de 
informalidade e de setor informal, já que associados apenas ao fenômeno do assalariamento ilegal, ou ao descumprimento das normas legais ${ }^{137}$.

O uso do critério da legalidade de forma unilateral tende a tornar praticamente equivalentes o setor informal e as formas de assalariamento ilegais, por exemplo. Isso possibilita que a separação entre formal e informal seja mensurada pela posse ou não de carteira de trabalho assinada, pela existência ou não de contratos de terceirização ou de franquia, entre outros parâmetros. Contudo, tais dados, geralmente não são analisados numa perspectiva histórica nem avaliados em seu conteúdo específico frente a uma dada conjuntura. Assim ao classificar um conjunto de atividades como informais mediante critérios rígidos, essas concepções tendem escamotear as ilegalidades e a precarização das relações de emprego que crescem em instituições e empresas formais acima de qualquer suspeita (MALAGUTI, 2000).

O próprio mercado de trabalho é tomado, na perspectiva neoclássica, como um efeito das várias qualidades e quantidades implicadas nas questões de oferta e demanda de mão-de-obra. As análises assim constituídas baseiam-se em mensurações derivadas da construção de diversos tipos de índices e no uso da teoria dos jogos, enfatizando o poder de escolha e discriminação de empresas e indivíduos, com pouca ou nenhuma consideração acerca das coerções estruturais da economia capitalista.

Em resumo, aspectos fundamentais como as implicações das relações entre formalidade e informalidade sobre as atividades do chamado setor informal ficam, na melhor das hipóteses, em segundo

\footnotetext{
${ }^{137}$ Cacciamali (2000, p. 154) indica, de forma expressa, que a associação entre setor informal e assalariamento ilegal é equivocada e aponta o trabalho de T. Merrick (1976), Employment and earnings in the informal sector in Brazil: the case of Belo Horizonte, como um exemplo desse equívoco. Em trabalhos mais recentes a evidência dessa associação é mais sutil. Contudo o setor informal continua a ser tratado como uma decorrência das flutuações da oferta e da demanda de postos de trabalho e não como uma conseqüência e um dado estrutural do processo de acumulação capitalista. Pautados em modelos econométricos e em sofisticada parafernália estatística os autores afeitos a essa abordagem pretendem que o setor informal seja analisado na perspectiva da livre escolha por parte de trabalhadores e empresas que optam, ou não, por integrar o setor informal, mediante cálculos racionais de custos, possibilidades e capacidades de diversas naturezas. Em seu texto Informalidade no mercado de trabalho brasileiro: uma resenha da literatura, Gabriel Ulyssea (2006) oferece uma ampla lista de autores que, a partir de abordagens empíricas, constroem perspectivas de análise acerca do setor informal que contemplam os elementos apontados acima.
} 
plano. Assim não é possível perceber que existem relações de produção que se estruturam de modo a criar certa continuidade entre os chamados setores formal e informal ${ }^{138}$ e tampouco insistir na existência de uma bipolaridade entre formal e informal na economia urbana.

No capitalismo a diferenciação entre formalidade e informalidade é de natureza econômica, social e política e não apenas legal. A ilegalidade é mais conseqüência do que causa e, portanto, não define por si só a existência do chamado setor informal. Em resumo, pode-se dizer que há uma trajetória do conceito de setor informal que indica, ao menos para determinados usos do conceito, a necessidade de precauções se a intenção for a construção de análises acerca da economia urbana, das cidades e da urbanização que não se limitem à caracterização das atividades e dos vínculos de trabalho como legais ou ilegais, essas novas dualidades que fragmentam a compreensão do urbano.

A economia solidária é outra abordagem que ganhou renovado vigor nos últimos anos. Diferentemente da teoria dos circuitos que se propõem a construir explicações para a dinâmica da economia urbana capitalista e para a formação dos circuitos como processos inerentes a esse modo de produção, a Economia Solidária se configura como uma proposta política que visa uma alternativa ao capitalismo.

Partindo de uma origem mais remota, o cooperativismo proposto pelos socialistas utópicos ${ }^{139}$, a economia solidária seria uma forma de organização econômica alternativa, isto é, formas de organização das trocas e da produção que apontam a possibilidade de construção de outro modo de produção. Suas características centrais tais como a posse coletiva dos meios de produção, a autogestão e as decisões

\footnotetext{
${ }^{138}$ Malaguti (2000, p. 101) apresenta diversos argumentos para demonstrar que essa oposição entre um setor formal e outro informal é no mínimo sujeita a muitos questionamentos. Dentre os argumentos do autor estão, por exemplo, estudos de caso que revelam a coexistência e a complementaridade entre formalidade e informalidade tanto em grandes empresas, como a Companhia Siderúrgica Nacional (CSN), como no caso de funcionários públicos que vendem produtos alternativos em seus respectivos locais de trabalho.

${ }^{139}$ Segundo Paul Singer (2002) a economia solidária teve origem no cooperativismo, entendido como reação à disseminação da pobreza e ao desemprego no início do século XIX em decorrência das transformações trazidas pela Revolução Industrial. Entre os pensadores que elaboraram propostas de organização econômica com base no cooperativismo estariam Robert Owen, Charles Fourier e Saint Simon.
} 
coletivas vão de encontro à premissa da igualdade entre os trabalhadores dos empreendimentos solidários.

Nós costumamos definir economia solidária como um modo de
produção que se caracteriza pela igualdade. Pela igualdade de
direitos, os meios de produção são de posse coletiva dos que
trabalham com eles - essa é a característica central. E a
autogestão, ou seja, os empreendimentos de economia solidária
são geridos pelos próprios trabalhadores coletivamente de forma
inteiramente democrática, quer dizer, cada sócio, cada membro do
empreendimento tem direito a um voto. Se são pequenas
cooperativas, não há nenhuma distinção importante de funções,
todo o mundo faz o que precisa. Agora, quando são maiores, aí há
necessidade que haja um presidente, um tesoureiro, enfim,
algumas funções especializadas, e isso é importante, sobretudo
quando elas são bem grandes, porque aí uma grande parte das
decisões tem que ser tomada pelas pessoas responsáveis pelos
diferentes setores. Eles têm que estritamente cumprir aquilo que
são as diretrizes do coletivo, e, se não o fizerem a contento, o
coletivo os substitui. É o inverso da relação que prevalece em
empreendimentos heterogestionários, em que os que
desempenham funções responsáveis têm autoridade sobre os
outros. (SINGER, 2008, p.289)

Para Singer (2008, p. 290) a importância da economia solidária estaria na clara indicação de que a alienação no trabalho que caracteriza as empresas capitalistas não seria inevitável. A recuperação de capacidades permitida pelos desafios de gerir a própria empresa, em geral na forma de cooperativas, seria um ganho inestimável para os trabalhadores educados no capitalismo que os acostuma a pensar que são menos aptos do que aqueles que os comandam. As falências de empresas que passam a ser administradas pelos empregados e são reconstruídas em bases solidárias demonstram que existem outras possibilidades. De forma semelhante, os clubes de troca apontam para inovações, como a criação de meios de circulação específicos e destinados a viabilizar formas de intercambio solidárias.

De acordo com os dados do Sistema Nacional de Informações em Economia Solidária (SIES) do Ministério do Trabalho e Emprego, no Brasil, o número de empreendimentos de economia solidária cadastrados passou de aproximadamente 2.000 empreendimentos no inicio dos anos 1980 para 21.859 empreendimentos cadastrados em 2008, envolvendo mais de 1,5 milhão de pessoas. O Paraná contava com 1404 
empreendimentos solidários e, em Londrina, havia 61 grupos cadastrados no Programa Municipal de Economia Solidária (PMES), criado em 2005. Em 2008, dentre os 61 grupos, 42 já estavam produzindo ${ }^{140}$ e outros 19 estavam em processo de formação, envolvendo, ao todo, cerca de 300 pessoas.

Em Londrina os grupos cadastrados no PMES recebem um amplo incentivo. A fragilidade da organização dos grupos transparece nas ações que a Prefeitura realiza para subsidiar as atividades da economia solidária. Em Londrina o PMES fornece local para "incubar" as atividades de alguns grupos no inicio produção e comercialização dos produtos. São desenvolvidas ações de assessoria aos empreendimentos econômicosolidários como o acompanhamento aos grupos de geração de trabalho e renda. No dia a dia os grupos são visitados e recebem suporte e capacitação necessários para organizar a produção e, principalmente, para o aperfeiçoamento na área de gestão, uma vez que se trata de uma forma diferente de organização do trabalho: o trabalho na perspectiva da autogestão.

Há também ações de fomento que podem ser efetivadas a partir do momento que os grupos se organizam e adquirem uma identidade, desenvolvendo um objetivo comum e decidindo o que vão produzir. O programa auxilia financeiramente a superar as dificuldades para adquirir a matéria prima e alguns equipamentos básicos para iniciar a produção. Existe a previsão de que após 2 anos os grupos passem a não depender do auxilio direto do PMES. No entanto, como o programa teve início em 2005, e como cada grupo tem ritmos diferentes de consolidação, é possível que diversos grupos necessitem de um período maior de atenção intensiva por parte dos técnicos do PMES.

Apesar do crescimento do número de empreendimentos e da importância dessas iniciativas no enfrentamento da crise que se abateu sobre o mercado de trabalho, há problemas na estruturação de muitas

\footnotetext{
${ }^{140}$ Dos 42 grupos em fase produção em Londrina, 14 dedicavam-se a produtos alimentares, 12 a artesanato, 6 a itens de vestuário, 4 a salões de beleza, 2 a reciclagem de resíduos sólidos, 2 a flores e outros 2 dedicados a marcenaria e instrumentos musicais.
} 
cooperativas que na verdade são apenas empresas capitalistas disfarçadas como empreendimentos econômico-solidários.

Pochmann (2004, p.31) argumenta que, apesar da necessidade de reconhecer as oportunidades geradas pela economia solidária, essas iniciativas enfrentam limitações. Na ausência de um conjunto amplo de políticas públicas que auxilie a viabilização dos empreendimentos os limites da economia solidária podem ser resumidos em cinco lacunas: a ausência de regulação pública para definir o estatuto da economia solidária, de um padrão de financiamento apropriado, de redes de produção e intercambio técnico, de inclusão dos empreendimentos em políticas voltadas para o comércio exterior e de inserção da produção dos empreendimentos econômico-solidários nas compras do setor público.

As iniciativas econômicas ligadas à economia solidária são relativamente recentes e é possível que seu amadurecimento revele de fato sua capacidade emancipatória. Observando os grupos que estão sob o acompanhamento do PMES em Londrina verificamos, contudo, que há uma forte dependência das várias formas de auxílio oferecidas por esse programa público.

Durante a entrevista com o Prefeito Nedson Micheleti o assunto dos programas relativos à economia solidária e ao microcrédito foram abordados. O Prefeito fez então um comentário revelador: "O público que é atendido pela economia solidária é muito diferente daquele do Moto Táxi ou do Camelódromo. Esse pessoal tinha uma disposição diferente de ir pro tudo ou nada. O pessoal da economia solidária precisa de mais apoio."

O próprio titular da Secretária Nacional de Economia Solidária, Paul Israel Singer, reconhece a necessidade de intervenção do 
poder público para possibilitar a superação das dificuldades da economia solidária ${ }^{141}$.

O que nos parece importante nessas observações é que as atividades realizadas no âmbito da economia solidária requerem subsídios técnicos, financeiros, comerciais, entre outros. Para atender a esses requisitos em sua totalidade se fazem necessárias políticas públicas sustentadas a médio e longo prazo com recursos relativamente abundantes.

As abordagens sobre as formas de enfrentamento e resistência às transformações no mundo do trabalho e à expansão da pobreza no período atual, que se apóia no conceito restrito de setor informal, assim como a análise sobre o desenvolvimento recente da economia solidária, guardam diferenças substantivas em relação à teoria dos circuitos da economia urbana.

$\mathrm{Na}$ teoria dos circuitos, há forte ênfase na necessidade de acompanhar a dinâmica histórica da pobreza como condição de não cair nas armadilhas do dualismo e suas versões atualizadas (MONTENEGRO, 2006). Um exemplo dessa atualização está nas abordagens que dividem de forma sumária as atividades econômicas em formais e informais, identificando e restringindo o setor informal à ilegalidade e a pobreza. Oblitera-se o fato de que, ao reproduzir ocupações mal remuneradas, mesmo com registro em carteira e vínculos formais de trabalho, o que seria o equivalente do setor formal nessa abordagem, também se expande a pobreza e se cria oportunidades para situações de ilegalidade.

\footnotetext{
${ }^{141}$ Infelizmente, muitas das cooperativas formadas por trabalhadores sofrem de escassez de capital e insuficiente acesso aos mercados, de modo que se vêem forçados a competir sacrificando seus próprios membros, embora isso em geral ocorra apenas nos primeiros tempos. [...]

Para enfrentar esses problemas, nosso projeto de lei prevê um programa de fomento, de apoio às cooperativas de trabalho. É o Programa Nacional de Fomento ao Cooperativismo do Trabalho (Pronacoop), em que primeiro dáse um prazo para que a cooperativa se adapte e passe a garantir os direitos trabalhistas para os seus sócios. Durante esse prazo, as cooperativas receberão assistência do governo para atingir plena suficiência econômica, necessária para cumprir a legislação. Elas receberão apoio para oferecer mercadorias ou serviços de mais qualidade, além de também terem acesso a crédito, tecnologia etc. Não temos nenhum interesse de ter uma economia solidária miserável, muito pobre. Mas essa é a realidade da economia solidária no Brasil hoje (SINGER, 2008, p.291).
} 
Ainda em relação à concepção de setor informal é necessário questionar a própria idéia da existência de setores econômicos, que ainda empregamos correntemente mais ou menos nos mesmos moldes em que Colin Clark (1940) os definiu.

A classificação em setores compreende uma grande abstração da economia que esconde o uso diferente do território pelos agentes. Atividades que teoricamente participariam de um mesmo "setor" apresentam, em realidade, conteúdos bastante diferenciados em termos de organização, de capital e de poder de interferência na organização do espaço. (MONTENEGRO, 2006, p.46)

$\mathrm{Na}$ análise da economia solidária o que se propõe é a construção de outro modo de produção, contudo a questão da dependência do fundo público constituído no âmbito do Estado capitalista permanece. A subvenção do Estado parece ser decisiva para sobrevivência da economia solidária.

$\mathrm{Na}$ teoria dos circuitos, a subordinação das atividades econômicas ligadas aos pobres se dá em relação ao setor dinâmico da economia, o circuito superior. A participação do Estado é reduzida e as relações entre os circuitos se constroem no âmbito do mercado. Essa questão coloca uma diferença constitutiva entre, por exemplo, as atividades do circuito inferior e os empreendimentos da economia solidária em Londrina. Por sua estruturação e funcionamento, o circuito inferior não se coloca como outro modo de produção e tampouco como criação de possibilidades emancipatórias. Todavia, nem por isso deixa de revelar o dinamismo e a luta dos que se vêem em posição estruturalmente subordinada contra as mazelas das políticas neoliberais e da globalização, esse outro nome para designar o período atual.

O que se revela com clareza na abordagem dos circuitos da economia urbana são os "dinamismos da pobreza e sua capacidade de criar trabalho" (SILVEIRA, 2004, p.70). A análise do entrelaçamento dos circuitos, ou seja, das relações entretecidas no âmbito de cada circuito e entre os circuitos superior, inferior e superior marginal, aponta tanto processos de subordinação como a criatividade e a capacidade de resistir 
que é engendrada pelas pessoas atingidas de forma mais contundente pelo desemprego e pelo empobrecimento.

De maneira igualmente importante essa análise contribui para o entendimento de como o meio construído e a cidade como um todo participam do entrelaçamento dos circuitos. A cidade ela própria se torna meio de trabalho, no sentido marxiano do termo, e não apenas para as atividades hegemônicas, mas em especial para o circuito inferior. A dimensão do lugar ganha destaque na compreensão de como se produzem a resistência e a busca de um cotidiano menos incerto e inseguro.

O circuito inferior em seu entrelaçamento com a cidade é também produtor de economia que se fundamenta no trabalho vivo e de dinamismos que se ligam ao modo de vida urbano.

Para discutir melhor e aprofundar esses argumentos analisaremos a seguir as características dos trabalhadores do circuito inferior em Londrina, procurando identificar suas especificidades e relacioná-las às transformações que ocorreram na divisão do trabalho no período atual. 


\section{3 - A caracterização dos trabalhadores do circuito inferior da economia urbana em Londrina}

Uma das diferenças significativas do circuito inferior no período atual é que os indivíduos que o compõe não são, como nos anos 1970, migrantes recém-chegados à cidade, com pouca escolaridade e pouco adaptados ao modo de vida urbano. Cabe então indagarmos:

- Quem são os trabalhadores do circuito inferior envolvidos nas três atividades pesquisadas?

- Onde residem?

- Com se inserem no modo de vida urbano?

Com base na caracterização desses trabalhadores procuramos estabelecer algumas relações entre os dados observados e a dinâmica própria à cada atividade e as variáveis que definem o período atual. 


\subsection{1 - As características de gênero, faixas etárias e estado civil}

Considerando as três atividades em conjunto, isto é, o Camelódromo, o Moto táxi e as Entregas Urbanas sete em cada dez trabalhadores são homens. Dentre as 56 mulheres (27\% do total), nada menos que 53 delas trabalhavam no Camelódromo de Londrina. As outras três mulheres eram mototaxistas das seguintes Centrais: Líder na área central, Cincão da zona norte e Titan da zona sul. Entre os motoboys não encontramos nenhuma "motogirl".

O cotidiano dos trabalhadores com moto exige uma combinação de esforço físico e resistência, combinação essa requerida para suportar tanto a exposição às intempéries quanto as extenuantes jornadas de trabalho no Moto Taxi e nas Entregas Urbanas, no entanto, nada disso é empecilho para participação das mulheres nessas atividades. De qualquer forma, o que se constata é que as mulheres são maioria no Camelódromo (proprietárias e funcionárias) e os homens predominam largamente nas atividades que envolvem o uso da moto como instrumento de trabalho.

Tabela 3

Trabalhadores (as) do circuito inferior em Londrina: caracterização quanto ao gênero, 2008.

\begin{tabular}{|c|c|c|c|c|c|c|c|c|}
\hline \multirow[t]{3}{*}{ Gênero } & \multicolumn{8}{|c|}{ Atividades do Circuito Inferior } \\
\hline & \multicolumn{2}{|c|}{ Camelódromo } & \multicolumn{2}{|c|}{ Moto Táxi } & \multicolumn{2}{|c|}{$\begin{array}{l}\text { Entregas } \\
\text { Urbanas }\end{array}$} & \multicolumn{2}{|c|}{ Total } \\
\hline & $\begin{array}{c}\text { N. de } \\
\text { Pessoas }\end{array}$ & $\%$ & $\begin{array}{c}\text { N.․ de } \\
\text { Pessoas }\end{array}$ & $\%$ & $\begin{array}{c}\text { N. de } \\
\text { Pessoas }\end{array}$ & $\%$ & $\begin{array}{c}\text { N. de } \\
\text { Pessoas }\end{array}$ & $\%$ \\
\hline Masculino & 28 & 35 & 71 & 96 & 52 & 100 & 151 & 73 \\
\hline Feminino & 53 & 65 & 3 & 4 & 0 & 0 & 56 & 27 \\
\hline Total & 81 & 100 & 74 & 100 & 52 & 100 & 207 & 100 \\
\hline
\end{tabular}

A maioria dos trabalhadores do circuito inferior é de jovens $(57,6 \%)$, são pessoas que têm até 30 anos de idade. Se considerarmos a faixa até 40 anos, período em que os trabalhadores estão em plenas condições de atividade, o percentual sobe para $80 \%$. 
Tabela 4

Trabalhadores (as) do circuito inferior em Londrina: caracterização quanto as faixas etárias, 2008.

\begin{tabular}{|c|r|r|}
\hline Faixas de idade (anos) & $\begin{array}{c}\text { N.o de } \\
\text { Pessoas }\end{array}$ & \multicolumn{1}{c|}{} \\
\hline $\mathbf{1 7}$ a 20 & 16 & 7,7 \\
\hline $\mathbf{2 1}$ a 30 & 103 & 49,9 \\
\hline $\mathbf{3 1}$ a 40 & 46 & 22,2 \\
\hline $\mathbf{4 1}$ a 50 & 28 & 13,5 \\
\hline 51 a 63 & 11 & 5,3 \\
\hline Sem informação & 3 & 1,4 \\
\hline
\end{tabular}

Fonte: Trabalho de campo, 2008

Entre os homens $57,5 \%$ tem até 30 anos e entre as mulheres o percentual é de $80 \%$. A maioria dos trabalhadores é de pessoas casadas - 53\% do total. Se considerarmos também os divorciados e separados o percentual sobe para 63\%. Os solteiros correspondem a $37 \%$.

Observando cada atividade nota-se que o maior percentual de solteiros aparece dentre os trabalhadores do Camelódromo (49\%) superando ligeiramente o de casados (48\%). No Moto táxi e nas Entregas Urbanas predominam os casados com percentuais de 57 e $54 \%$ do total de entrevistados, respectivamente. A maioria dos trabalhadores das três atividades está ligada a uma família na qual tem papel central como responsável. 


\subsection{2 - Localização, distribuição e caracterização dos domicílios}

A localização e distribuição dos trabalhadores das três atividades pesquisadas em Londrina estão representadas nos mapas a seguir $^{142}$. O primeiro deles mostra a distribuição dos proprietários e funcionários do Camelódromo de Londrina.

Mapa 13

Londrina: distribuição dos domicílios trabalhadores do Camelódromo, 2008

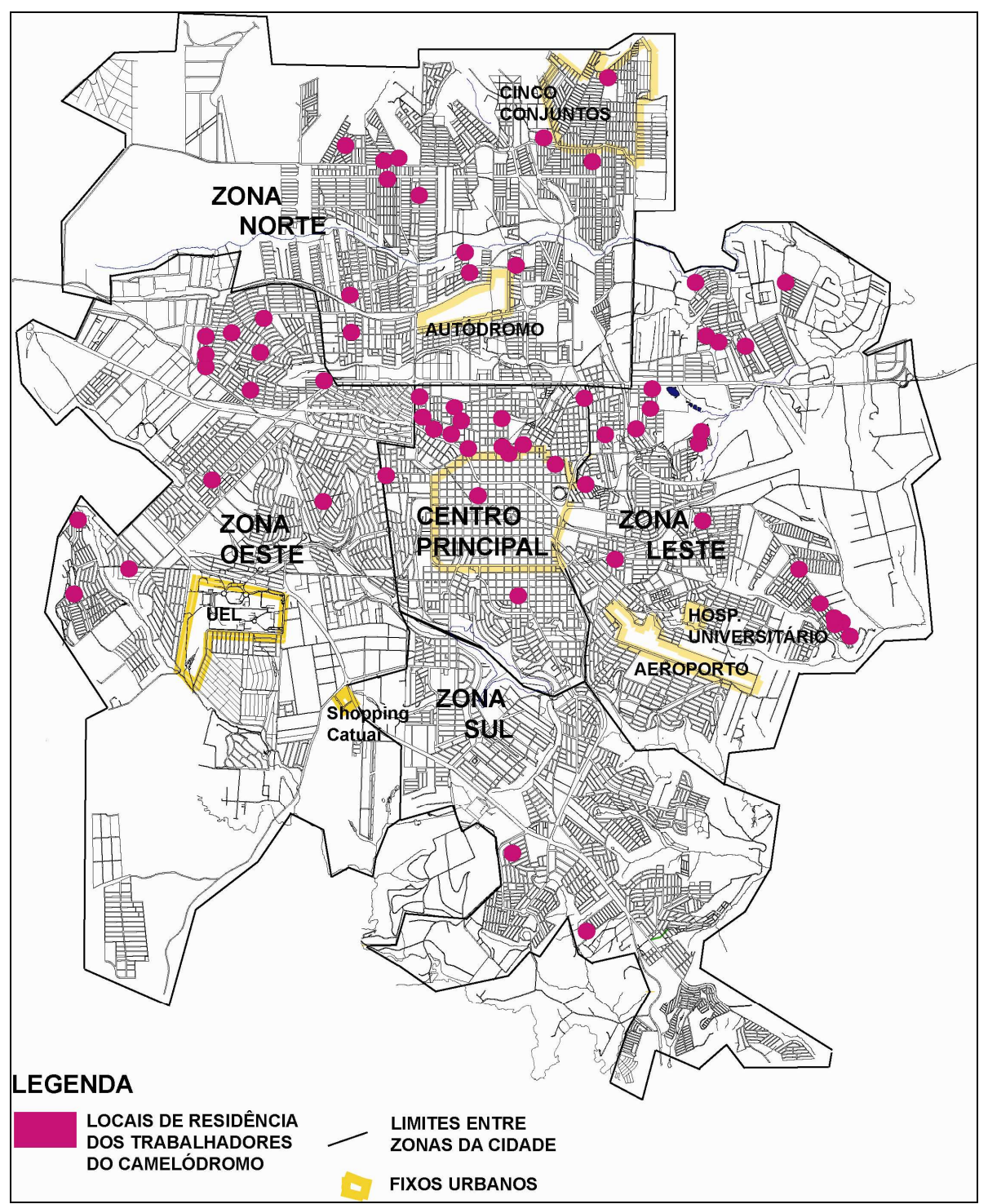

Fonte: Trabalho de campo, 2008

${ }^{142} \mathrm{O}$ número de trabalhadores representados no mapa (64 pessoas) é menor do que o de entrevistados (81). A diferença ocorre por conta da perda de informação (pessoas que não indicaram o endereço) e para evitar a identificação das pessoas. 
A maioria dos trabalhadores do Camelódromo reside na zona leste e na área central da cidade, contrastando com a zona sul com apenas 2 trabalhadores. Na área central ocupam bairros situados ao norte da antiga ferrovia que, historicamente, abrigaram a população pobre de Londrina. Há ainda 13 trabalhadores espalhados na zona norte e outros 13 na zona oeste. Essa distribuição é significativa porque revela que a grande parte dos trabalhadores do Camelódromo reside em "bairros populares" muitos deles formados a partir de conjuntos habitacionais construídos nos anos 1970 e $1980^{143}$.

No mapa a seguir, o padrão de distribuição dos locais de residência dos mototaxistas também acompanha a localização dos bairros populares da cidade, sobretudo os que se formaram ou se consolidaram nos anos 1970 e 1980. A zona norte se destaca com a maior parte dos pontos cartografados ${ }^{144} \mathrm{e}$ a área central é a menos representativa em relação aos locais de residência dos mototaxistas do que para os trabalhadores do Camelódromo. As zonas leste e sul também abrigam um número razoável de mototaxistas, os quais, tal como ocorre com os trabalhadores do Camelódromo, também residem em bom número em bairros formados a partir conjuntos habitacionais ${ }^{145}$.

De forma semelhante ao que ocorre na distribuição dos trabalhadores do Camelódromo na cidade, alguns mototaxistas também

\footnotetext{
${ }^{143} \mathrm{Na}$ área os trabalhadores se concentram na Vila Nova e outros bairros próximos da Avenida Leste-Oeste, antiga linha do trem. Historicamente os bairros situados ao norte da ferrovia, especialmente as Vilas que aí se formaram, abrigaram a população pobre da cidade. apesar de constituírem atualmente espaços de relativa valorização, ainda guardam esse conteúdo social. Na zona oeste os trabalhadores se concentram no jardim Leonor e no extremo oeste da cidade no Jardim Olímpico e no Conjunto Avelino Oliveira, sendo que estes dois últimos são bairros resultantes de expansão relativamente recente (anos 1990) e reúnem majoritariamente população muito pobre. Na zona leste destacam-se os Conjuntos Mister Thomas e adjacências, mais próximos da zona norte, e o Conjunto Ernani Moura Lima, próximo do Hospital Universitário. Na zona norte, onde foi construída boa parte dos conjuntos habitacionais de Londrina, os trabalhadores do Camelódromo estão distribuídos em diversos conjuntos como, por exemplo, o Parigot de Souza mais a oeste, o Conjunto Ruy Virmont Carnascialli nas proximidades do autódromo e os Conjuntos Maria Cecília, Semíramis e Aquiles Stenghel que são parte dos chamados Cinco Conjuntos.

${ }^{144}$ Foram representados 49 locais de residência dos 74 mototaxistas entrevistados. A zona norte abriga 21 locais de residência.

${ }^{145} \mathrm{Na}$ distribuição dos locais de residência dos mototaxistas os conjuntos das zonas norte e leste, já mencionados na analise da distribuição dos trabalhadores do Camelódromo, se repetem: Cinco Cojuntos, Parigot de Souza, Vivi Xavier, Ernani Moura Lima, Mister Thomas, etc. Aparecem como novidade os conjuntos habitacionais da zona sul: Cafezal I e II, Conjunto Roseira e Conjunto Parque das Industrias e ainda alguns bairros de expansão relativamente recente (anos 1990) como Jardim Franciscato e o Jardim Joana.
} 
residem em bairros afetados pela pobreza de forma mais intensa. É o caso do Jardim União da Vitória, bairro situado no extremo sul de Londrina e que resultou de um processo de ocupação nos anos 1990.

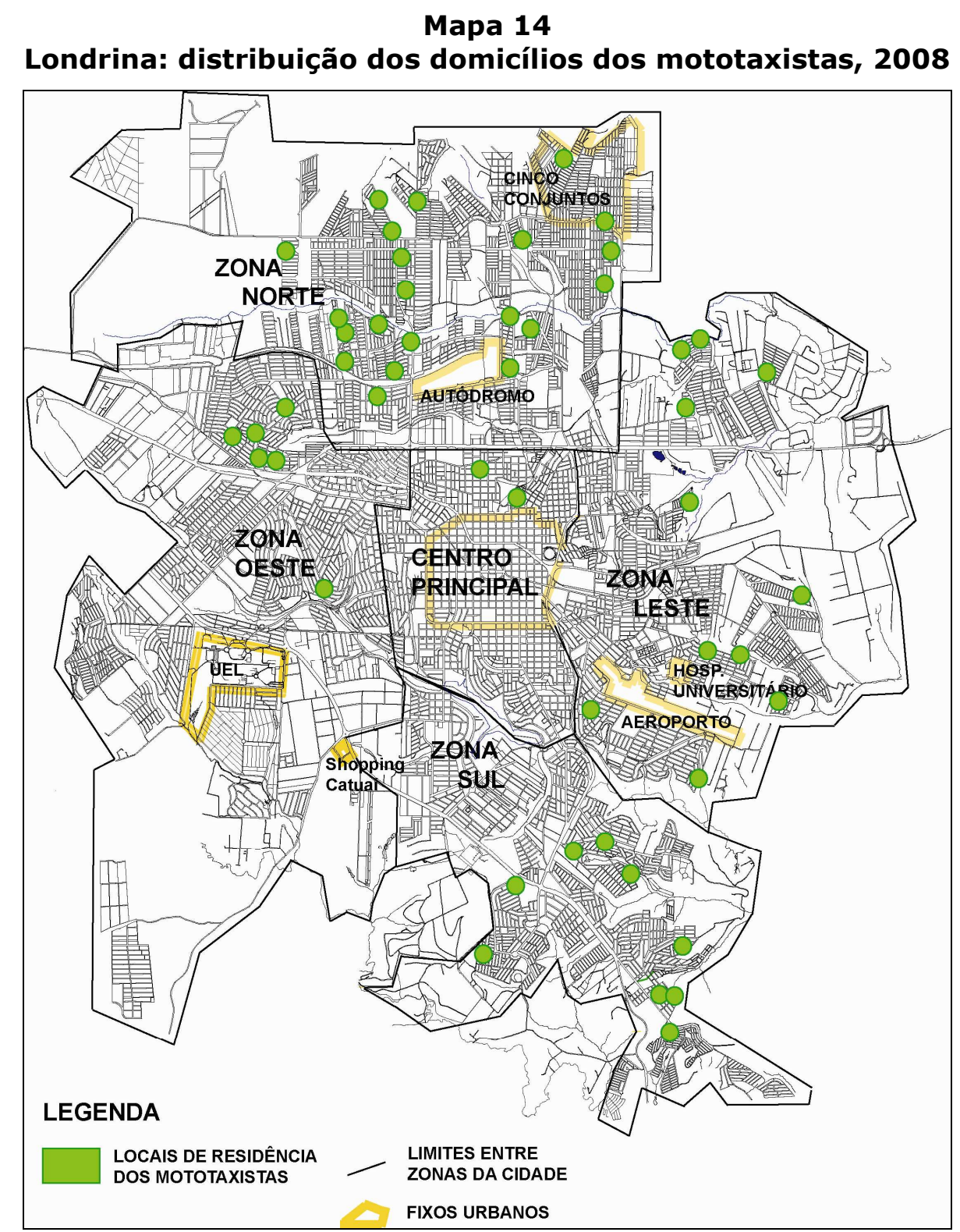

Fonte: Trabalho de campo, 2008

O próximo mapa indica a distribuição dos locais de residência dos motoboys ${ }^{146}$. O padrão de distribuição se repete. A zona norte abriga, nesse caso, mais da metade dos locais de residência e área central tem apenas uma ocorrência. As zonas sul e leste vêm a seguir em número de pontos cartografados. A identificação dos locais de residência

\footnotetext{
${ }^{146}$ Foram representados 43 locais de residência de 52 motoboys entrevistados.
} 
novamente coincide com os conjuntos habitacionais e bairros resultantes de expansão relativamente recente ${ }^{147}$.

Mapa 15

Londrina: distribuição dos domicílios dos motoboys, 2008.

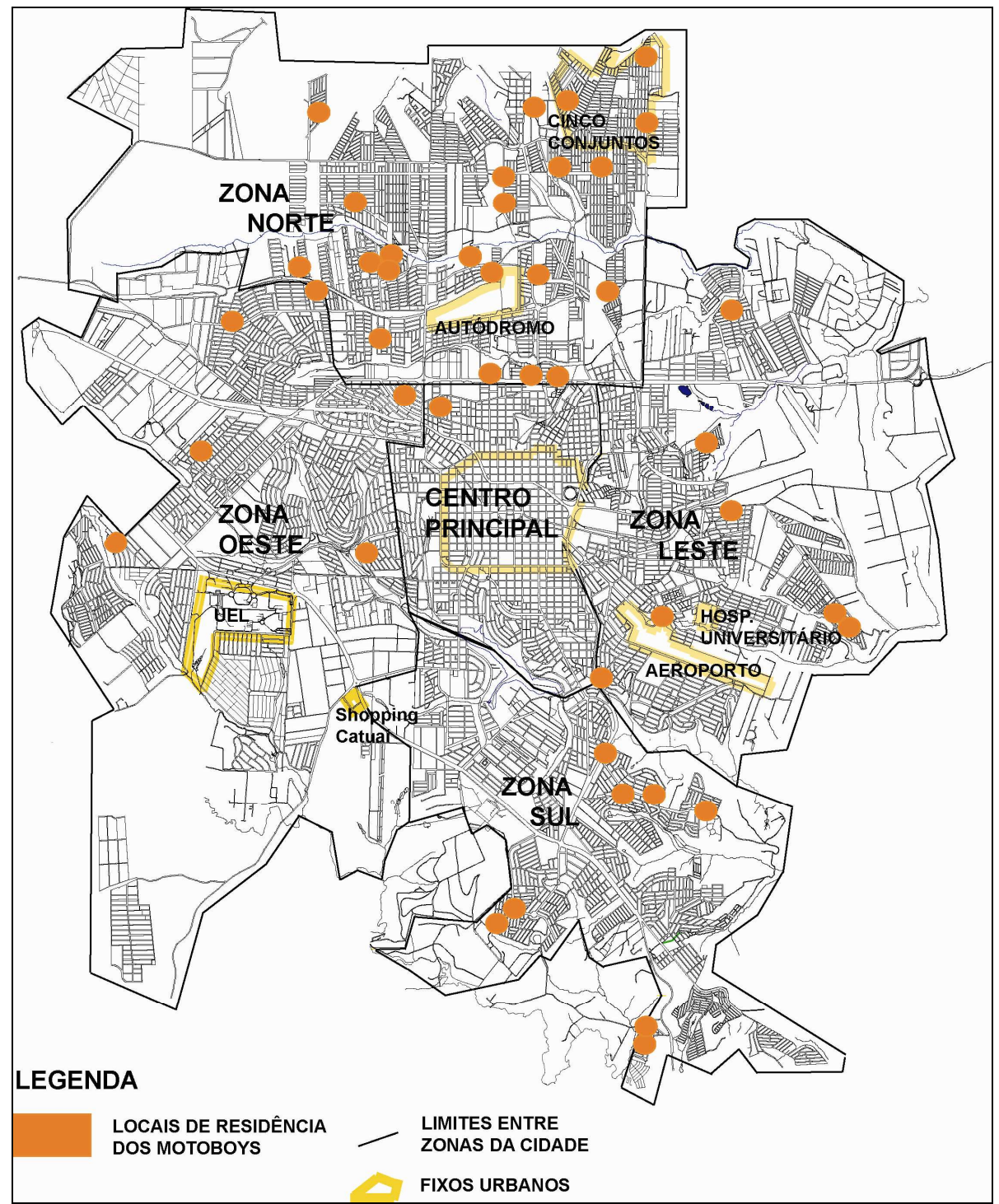

Fonte: Trabalho de campo, 2008

Para um melhor entendimento da relação entre a distribuição dos locais de residência dos trabalhadores do circuito inferior e sua inserção na estrutura e no modo de vida urbanos, produzimos um mapa em que procuramos correlacionar essa distribuição com as faixas de rendimento da população como um todo.

\footnotetext{
${ }^{147}$ Destacamos nesse caso o Jamile Dequech no extremo sul da cidade, bairro que também resultou de processos de ocupações no final dos anos 1990 e inicio dos anos 2000. Situado em local de topografia movimentada esse bairro, assim como os do extremo oeste da cidade é afetado pro situações de extrema pobreza e exclusão. Na zona norte outro ponto indica situação semelhante. É o assentamento Jardim são Jorge situado na parte mais a oeste da zona norte, opondo-se e alinhando-se com os Cinco Conjuntos.
} 


\section{Mapa 16}

Londrina: Distribuição dos trabalhadores do circuito inferior e setores censitários com no mínimo $20 \%$ de responsáveis por domicílio com rendimentos até 2 sal. mínimos, 2008.

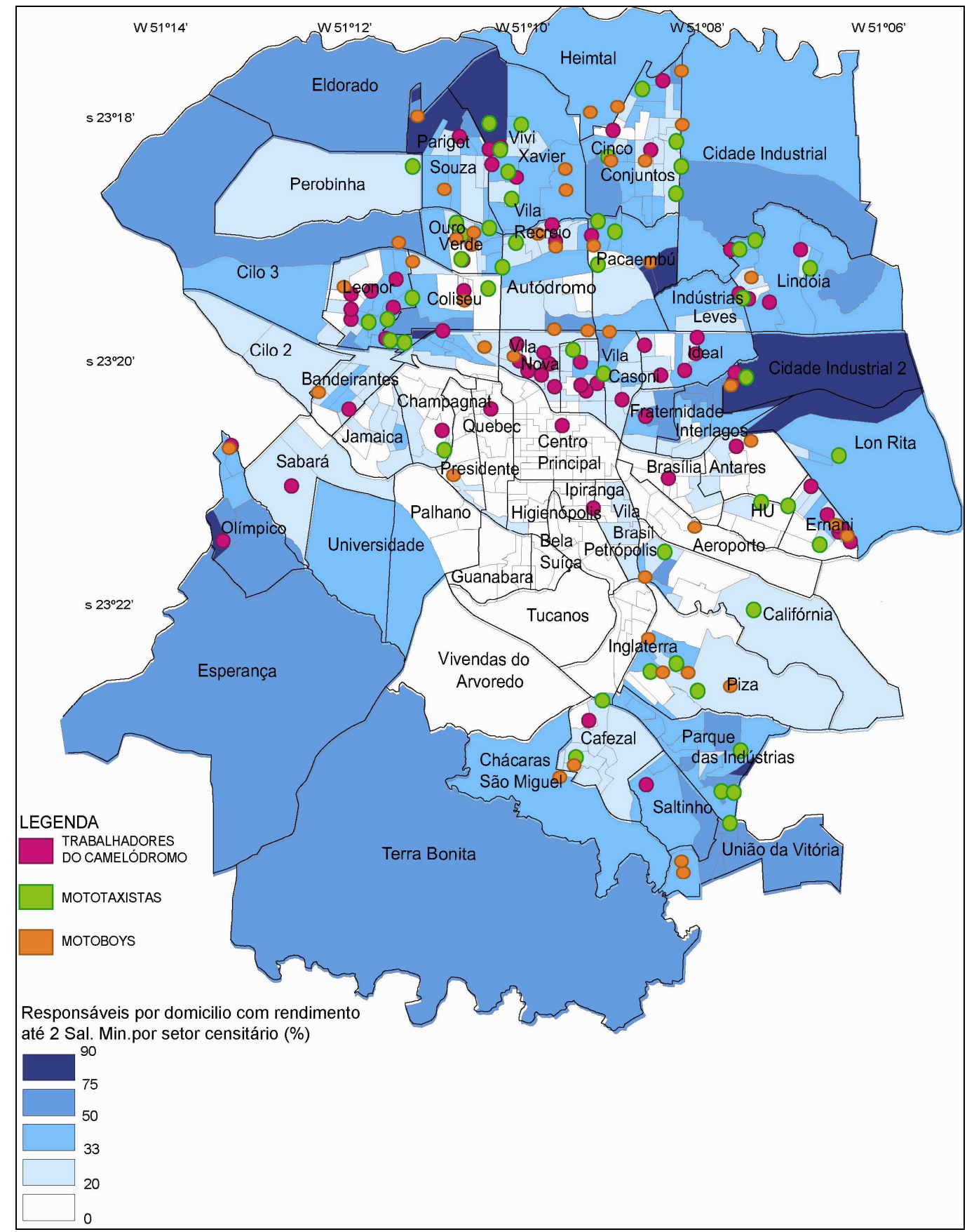

Fonte: Censo Demográfico 2000, Atlas Ambiental de Londrina e Trabalho de campo, 2008 
A distribuição dos trabalhadores das três atividades analisadas coincide, de forma aproximada, com a distribuição dos setores censitários em que há mais de um terço dos responsáveis pelo domicílio com rendimentos de até 2 salários mínimos (IBGE, 2000). Essa informação confirma a relação entre a localização da parcela da população que conta com menores rendimentos e domicílios nos quais, os trabalhadores do circuito inferior, contribuem diretamente para o sustento das famílias. O circuito inferior concorre, portanto, para amenizar o empobrecimento, auxilia a resistir à perda progressiva da capacidade de encontrar trabalho e, assim, contribui para que pelo menos se consiga manter o que foi conquistado, como a casa, os equipamentos domiciliares, etc., que são parte da base material do cotidiano.

As políticas de habitação dos anos 1970 até meados dos anos 1980, apesar de todo contexto autoritário e de suas insuficiências, produziram certos resultados em Londrina. Como vimos os trabalhadores das três atividades pesquisadas se localizam, em muitos casos, nos conjuntos habitacionais construídos nesse período, ou em bairros populares surgidos de loteamentos abertos nos anos 1990. Esse contexto de oferta de residências modestas repercute no fato de que nada menos que $59 \%$ dos trabalhadores do circuito inferior declararam morar em casa própria. O aluguel pesa no orçamento doméstico de $27 \%$ dos entrevistados e apenas $14 \%$ declararam morar com os pais.

Gráfico 17

Londrina: equipamentos domiciliares nas residências dos trabalhadores do circuito inferior, 2008. (\%)

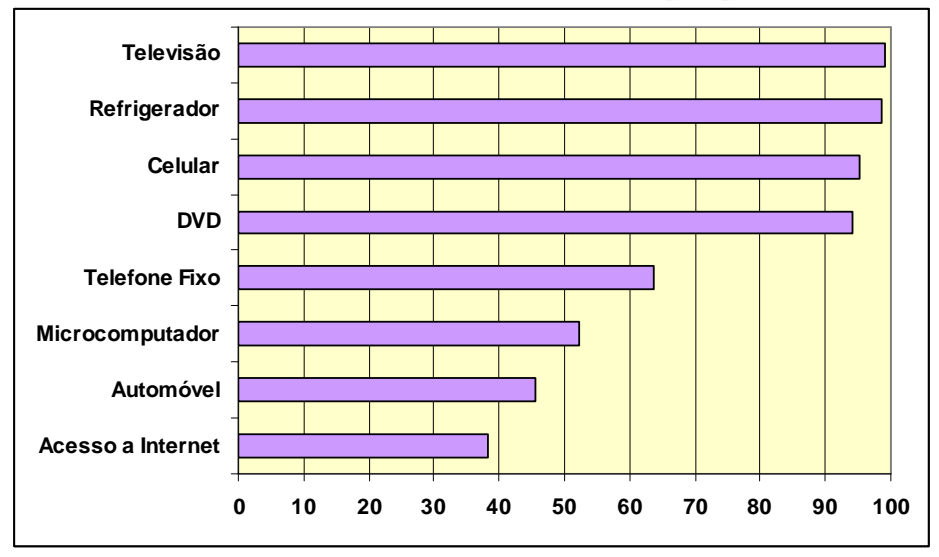

Fonte: Trabalho de campo 
Os domicílios dos trabalhadores do circuito inferior possuem os equipamentos básicos que correspondem à vida urbana no contexto atual. As condições materiais dos domicílios dos trabalhadores nas três atividades estudadas revelam a luta pela conquista do cotidiano. Conforme Amélia Damiani (1993) o cotidiano é mais do que uma ordem imposta, compreende também "no plano subjetivo, uma organização de vida assegurada". A autora complementa afirmando que o cotidiano está ligado à busca de alguma segurança no que diz respeito às necessidades do dia a dia.

Quando o banal do dia a dia, como se alimentar, vestir-se, alojarse, locomover-se, produzir, faz parte da vida de forma segura. Com esses tempos, atividades e espaços conquistados de maneira que parece definitiva. É a ordem diária da segurança material. Tendo cotidiano se dorme em paz (DAMIANI, 1993, p.20).

O desemprego, especialmente quando prolongado, faz crescer a insegurança e ameaça a continuidade do cotidiano que foi alcançado a duras penas e ao longo de gerações. Manter o cotidiano significa muitas vezes lutar para não cair na invalidação por envelhecimento ou no descarte prematuro (CASTEL, 1998).

Manter o cotidiano conquistado implica também acompanhar as transformações técnicas que despejam sobre nossas cabeças novos objetos e com eles, novas possibilidades e necessidades. Os novos objetos técnicos, como o telefone celular, já se fazem mais presentes no cotidiano dos trabalhadores do circuito inferior do que o telefone fixo ou $o$ automóvel. O celular não é somente um objeto de desejo, é também fundamental no trabalho de mototaxistas e motoboys. A possibilidade de comprar equipamentos usados e renová-los e de obter uma linha prépaga facilitam a difusão desse equipamento. A combinação entre televisores e DVDs permite dispor de formas de lazer que não se restringem à programação das emissoras de televisão aberta.

Outra dimensão implicada na presença marcante de alguns equipamentos nos lares dos trabalhadores do circuito inferior é a difusão e a intensificação do consumo que, no Brasil, se estende para além das classes médias nos anos 1990, atingindo também as classes menos 
favorecidas, mediante forte expansão do crédito (SANTOS e SILVEIRA, 2001, p.229).

A combinação resultante desse conjunto de características indica que, no período atual, os atores do circuito inferior diferem substantivamente daqueles que nos anos 1970 enfrentavam a vida nas regiões metropolitanas, como migrantes recém-chegados desprovidos de condições materiais que pudessem favorecer o acesso ao cotidiano. Naquele momento, a esperança ficava por conta de conseguir um emprego na indústria, incluindo a construção civil, organizar a vida, conseguir uma casa, criar os filhos. Ou ainda, após passar algum tempo como empregado registrado em alguma empresa, usar os recursos da rescisão contratual para iniciar um pequeno negócio por conta própria.

No período atual, a situação dos trabalhadores do circuito inferior parte de um cotidiano ameaçado. A contrapartida negativa da luta pela manutenção desse cotidiano tem sido a precarização das condições de trabalho que se expressa nos riscos (assaltos, acidentes, etc.), na ausência de acesso à seguridade social e nas jornadas de trabalho extenuantes a que estão submetidos esses trabalhadores. 


\subsection{3 - Renda mensal, jornadas e vínculos de trabalho}

A renda líquida mensal obtida nas atividades do circuito inferior varia conforme a atividade. Os menores rendimentos mensais ${ }^{148}$ são auferidos pelos que são empregados. Considerando apenas os ganhos na atividade principal os funcionários do Camelódromo ganham, em média, R\$557,00 e os motoboys R\$ $626,00^{149}$.

Os ganhos líquidos médios mensais dos trabalhadores por conta própria são um pouco maiores. Os mototaxistas ganham, em média, R\$ $855,00^{150}$ e os maiores ganhos são auferidos pelos pequenos comerciantes do Camelódromo, R\$1.614,00.

Gráfico 18

Londrina: rendimentos líquidos declarados pelos trabalhadores nas três atividades, 2008. (n. de Pessoas)

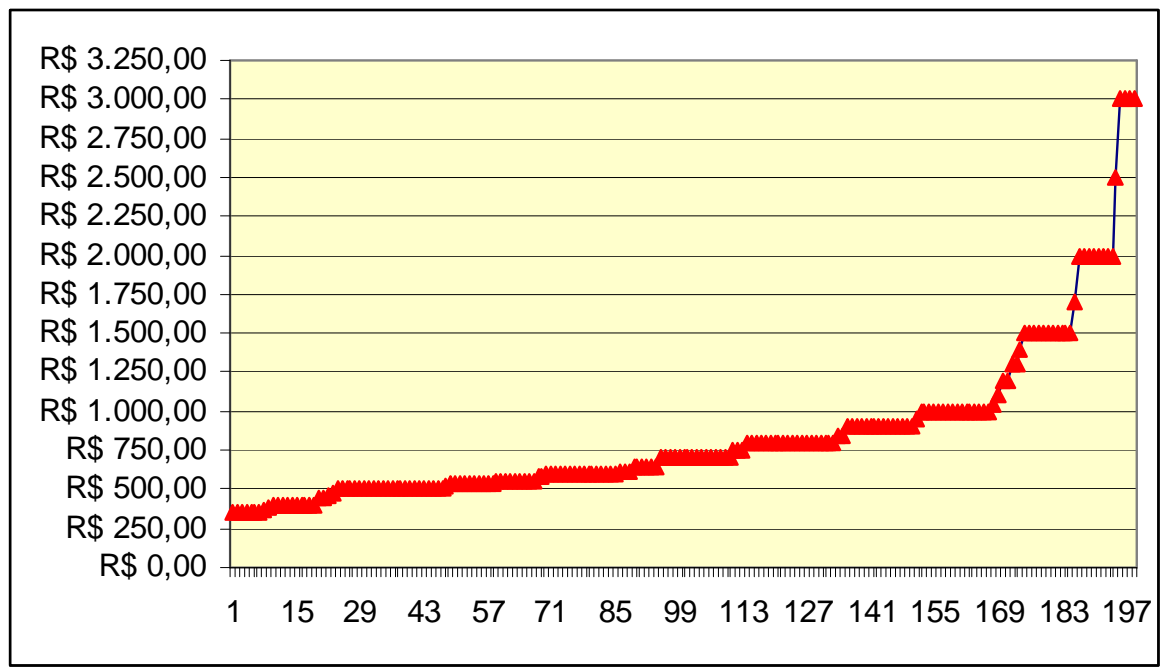

Fonte: Trabalho de campo, 2008

Observação: No eixo (x) estão representadas cada uma das pessoas que informaram seus ganhos. Foram desprezados o maior e o menor valor declarados. As informações de 8 entrevistados foram descartadas por serem incompletas ou inconsistentes.

\footnotetext{
${ }^{148}$ Conforme a Lei Federal $\mathrm{n}^{\circ} 11.709$, de 19.06.2008 o valor do salário mínimo era de R\$ 415,00, e no Paraná segundo a Lei Estadual $\mathrm{n}^{\mathrm{o}} 15826$ o menor salário mínimo era de $\mathrm{R} \$ 527,00$, pago aos trabalhadores da agricultura e o maior era de $\mathrm{R} \$ 548,00$ pago aos técnicos de nível médio.

${ }^{149}$ Os ganhos totais dos motoboys são muito variáveis. Há diversas situações: ganhos com horas extras, ajudas de custo, ganhos com taxas de entrega que variam conforme a distância e o tipo de entrega. Além disso, $42 \%$ dos motoboys trabalham em um emprego registrado e tem outra atividade como bico: pizzarias, farmácias pequenas nos fins de semana, lanchonetes, lojas de autopeças etc. Os ganhos totais dos motoboys são, em média, aproximadamente $\mathrm{R} \$ 950,00$.

${ }^{150}$ Em menor proporção do que os motoboys, alguns mototaxistas, $25 \%$ do total, exercem uma segunda atividade além do Moto Táxi, tais como: vigilantes, entregadores em farmácias, lanchonetes e pizzarias, vendedores e garçons.
} 
Alguns motoboys, mototaxistas e funcionários do Camelódromo ${ }^{151}$ complementam os rendimentos com alguma outra atividade nos fins de semana, o popular bico, ou até mesmo um emprego formal noturno. No caso dos proprietários de estabelecimentos do Camelódromo os ganhos variam conforme o tipo de produto vendido.

A grande maioria dos entrevistados, isto é $73 \%$ do total (151 pessoas), ganham menos de $\mathrm{R} \$ 1.000,00$ por mês. Considerando as três atividades, a renda média dos trabalhadores é de $\mathrm{R} \$ 840,00$.

Para obter esses rendimentos as jornadas de trabalho são variadas. Os motoboys que trabalham apenas em um emprego (58\%) costumam fazer horas extras. A jornada básica é de 8 horas diárias de segunda a sexta feira. O trabalho começa entre oito e nove da manhã e termina entre quatro e seis da tarde, com intervalos regulares para almoço e lanche. As horas extras começam após as seis da tarde e prolongam a jornada até as dez ou onze da noite. As jornadas diárias chegam a superar 12 horas diárias.

Os motoboys que tem duas ocupações trabalham até cinco ou seis da tarde e, especialmente nos fins de semana, trabalham entregando lanches, pizzas e remédios. Nesse caso as jornadas podem se estender aos 7 dias da semana, com durações variadas.

Os mototaxistas trabalham seis dias por semana cumprindo jornadas de 10 a 12 horas diárias. As jornadas diárias começam entre sete e oito da manhã e terminam entre as sete e oito da noite, sem intervalos regulares. Em geral descansam entre uma corrida e outra e almoçam rapidamente em algum momento entre as onze da manhã e as duas da tarde, conforme o ritmo das corridas.

Os mototaxistas que têm duas ocupações começam mais cedo, por volta das sete da manhã, e param por volta das quatro da tarde. Retomam o trabalho após as seis da tarde e a duração da segunda

\footnotetext{
${ }^{151}$ Dentre essas três atividades os percentuais de pessoas que declararam ter uma segunda atividade variam de $17 \%$ para os funcionários do Camelódromo até $42 \%$ no caso dos motoboys.
} 
jornada varia conforme a atividade e o dia da semana. Nesse caso as jornadas totais também ultrapassam 12 horas diárias.

Em compensação aos menores rendimentos os funcionários de estabelecimentos do Camelódromo são os que cumprem jornadas menos extenuantes. A grande maioria (72\%) trabalha seis dias por semana das nove da manhã às seis da tarde, com intervalos regulares para almoço e lanche.

Os proprietários cumprem os mesmos horários dos funcionários, só que sem os intervalos. Além disso, viajam para comprar novas mercadorias, inclusive nos fins de semana. Quanto aos vínculos de trabalho e as contribuições para aposentadoria a situação também é diferenciada conforme a atividade.

No Camelódromo ocorrem duas situações típicas. Em 64\% dos estabelecimentos trabalham o proprietário(a) sozinho(a) ou com a ajuda de mais uma pessoa. Em parte desses estabelecimentos, a ajuda vem de um parente do proprietário(a) aproximando-se da situação de trabalho familiar e, nos demais, a ajuda vem de pessoas contratadas. Em $36 \%$ dos estabelecimentos, há duas ou mais pessoas além do proprietário, em geral, com vínculos formais de trabalho e registro em carteira.

Entre os proprietários que concederam entrevista e responderam ao questionário (34 pessoas) $60 \%$ recolhe as taxas e tributos para aposentadoria.

A quase totalidade dos motoboys entrevistados (91\%) é empregada formal de empresas de entregas urbanas. Essa atividade exemplifica o modo como as baixas remunerações em empregos formais também estimulam a informalidade. Trabalhadores com vínculos de trabalho formais procuram bicos e outras atividades sem registro em carteira para complementar os rendimentos e fazer frente às necessidades do modo de vida urbano. O aspecto positivo fica por conta de que, com o vínculo formal, esses trabalhadores mantêm contribuições para 
aposentadoria e acesso a direitos trabalhistas como garantias de renda em caso de acidente de trabalho, férias e décimo terceiro salário.

O circuito inferior, por outro lado, não se resume a vínculos de trabalho informais ou à ajuda de parentes e pessoas próximas. As Centrais de Moto Taxi e os estabelecimentos do Camelódromo empregam 50 pessoas com registro em carteira, o que corresponde a $54 \%$ dos postos de trabalho gerados nessas duas atividades.

A situação de vulnerabilidade é marcante no Moto Táxi. Dentre os 74 entrevistados, 61 pessoas (82\%) declararam sem hesitar que, em caso de acidentes, doenças ou outras necessidades particulares não dispõem de nenhuma cobertura. Os rendimentos cessam de imediato e as obrigações continuam e se acumulam, fica-se ameaçado, por exemplo, de perder o instrumento de trabalho: a moto, uma vez que a maioria paga religiosamente as parcelas do financiamento usado para adquirir esse bem. $O$ seguro recolhido mensalmente cobre apenas casos de invalidez permanente e morte.

Apenas $26 \%$ dos mototaxistas recolhem contribuições para aposentadoria e nem todos o fazem de forma contínua. Somente dois entrevistados conseguem manter seguros contra acidentes pessoais e em apenas uma das trinta e cinco Centrais visitadas encontramos mototaxistas que são assalariados formais.

O circuito inferior é, portanto, bastante heterogêneo quanto às situações de informalidade e precarização dos vínculos de trabalho. Classificações rígidas e niveladoras, a exemplo das que empregam o conceito restrito de setor informal, mais ocultam do que elucidam a dinâmica própria da pobreza na cidade capitalista e da luta contra o empobrecimento. 


\section{4 - As razões da entrada e da permanência dos trabalhadores nas atividades do circuito inferior exercidas por conta própria}

Conforme já dissemos, a geração de trabalhadores que atualmente está nas atividades do circuito inferior não é composta de migrantes recém-chegados à cidade como nos anos 1970 e 1980 . Pouco mais da metade dos 207 entrevistados, isto é, 54\% deles, nasceu em Londrina; e a grande maioria nasceu no Paraná, especialmente em municípios da região norte, somando $83 \%$ do total. Notamos que se trata de pessoas que estão inseridas há algum tempo no modo de vida urbano.

O cotidiano desses trabalhadores, em razão das modernizações que a cidade acolheu, torna-se instável pela ameaça de não conseguir emprego ou ocupação, pela ameaça de ser levado à condição de supranumerário (CASTEL, 1998).

\section{Tabela 5}

Migrantes, não migrantes no circuito inferior - Londrina, 2008.

\begin{tabular}{|c|c|c|}
\hline $\begin{array}{c}\text { Tempo de residência } \\
\text { em Londrina (anos) }\end{array}$ & $\begin{array}{c}\text { N. } \\
\text { Pesso de }\end{array}$ & \% \\
\hline MENOS DE 1 & 1 & 0,5 \\
\hline $\mathbf{1}$ a 2 & 7 & 3,4 \\
\hline $\mathbf{3}$ a 5 & 10 & 4,8 \\
\hline a 10 & 11 & 5,3 \\
\hline $\mathbf{1 1}$ a 15 & 13 & 6,3 \\
\hline MAIS DE 20 & 23 & 11,1 \\
\hline SEMPRE MOROU & 63 & 30,4 \\
\hline TOTAL & $\mathbf{2 0 7}$ & 38,2 \\
\hline
\end{tabular}

Fonte: Trabalho de campo, 2008.

Antes de conseguir um estabelecimento no Camelódromo de Londrina ou trabalhar como mototaxista, atividades em que as pessoas atuam como trabalhadores por conta própria, a quase totalidade dos entrevistados teve uma ocupação no mercado formal de trabalho com o devido registro em carteira.

As atividades analisadas indicaram que, em Londrina, nas duas últimas décadas, a instabilidade, minimizada em períodos anteriores 
pela expansão da relação salarial, tornou-se crescente, a ponto de projetar sobre o cotidiano urbano uma sombra de preocupação.

Tabela 6

Participação dos trabalhadores autônomos no mercado formal de trabalho, 2008

\begin{tabular}{|c|c|c|c|c|c|c|}
\hline \multirow{2}{*}{$\begin{array}{c}\text { Trabalhou com carteira } \\
\text { assinada antes da atividade } \\
\text { atual? }\end{array}$} & \multicolumn{4}{|c|}{ N.o de Entrevistados } & \multicolumn{2}{|c|}{ Totais } \\
\hline & SIM & $\%$ & NÃO & $\%$ & & \\
\hline $\begin{array}{l}\text { Proprietários de } \\
\text { estabelecimentos no } \\
\text { Camelódromo }\end{array}$ & 29 & 85,3 & 5 & 14,7 & 34 & 100 \\
\hline Mototaxistas & 67 & 90,5 & 7 & 9,5 & 74 & 100 \\
\hline Total & 96 & 88,9 & 12 & 11,1 & 108 & 100 \\
\hline
\end{tabular}

Fonte: Trabalho de campo, 2008

Observação: A questão sobre a posse de carteira assinada em atividades anteriores só foi respondida pelos trabalhadores que potencialmente perderam seus vínculos formais de trabalho. Não responderam a essa questão os funcionários do camelódromo (47 entrevistados) e os motoboys que, em sua totalidade, possuem registro em carteira (52 entrevistados).

A instabilidade manifesta-se na intermitência da ocupação e da renda e na insuficiência desta última. Objetivamente, as informações fornecidas pelos entrevistados indicam que suas trajetórias no mercado formal de trabalho foram compostas de muitas atividades, quase sempre de baixa remuneração e que, uma das causas de sua passagem para o comércio ambulante e o trabalho autônomo no moto taxi, foi o desemprego.

Em Londrina, assim como em outras cidades, o desemprego tende a se tornar prolongado, no caso dos jovens e também das pessoas com mais de 45 anos e com pouca escolaridade. A condição de desempregado foi apontada por $64 \%$ dos entrevistados como razão para adquirir a primeira moto e iniciar no Moto Táxi e por $61 \%$ dos proprietários entrevistados no Camelódromo como razão para iniciar um negócio próprio.

A remuneração insuficiente foi outra razão objetiva, indicada pelos entrevistados para mudar de atividade, deixando para trás o 
assalariamento formal ${ }^{152}$. Essa razão foi manifestada pelos entrevistados desempregados e que, nas oportunidades de emprego que encontraram, teriam de se adaptar a um salário liquido menor do que a renda auferida como mototaxista.

Segundo a Companhia de Desenvolvimento de Londrina (CODEL, 2003, p.9), em 2003, o salário médio na cidade girava em torno de $R \$ 750,00$. Esse número, contudo não reflete a remuneração das funções exercidas pela maioria dos entrevistados que é, em geral, inferior a essa média ${ }^{153}$.

Com mais ênfase ainda a baixa remuneração em empregos anteriores com carteira assina foi apontada por muitos entrevistados que não indicaram o desemprego como razão de sua passagem para a nova atividade. Alguns foram incisivos quanto à insatisfação com o rendimento obtido no último emprego ou ocupação e ao fato de que sua permanência na nova atividade se devia, entre outros motivos, à melhor remuneração obtida. A tabela revela que mais da metade dos mototaxistas e dos proprietários do Camelódromo está há mais de 5 anos militando na atividade.

Tabela 7

Tempo de trabalho em atividades por conta própria, 2008.

\begin{tabular}{|c|c|c|c|c|c|c|}
\hline \multirow{3}{*}{$\begin{array}{l}\text { Tempo de trabalho na } \\
\text { atividade (anos) }\end{array}$} & \multicolumn{6}{|c|}{ Atividades por conta própria } \\
\hline & \multicolumn{2}{|c|}{$\begin{array}{c}\text { Como pequeno } \\
\text { comerciante }\end{array}$} & \multicolumn{2}{|c|}{$\begin{array}{c}\text { Como } \\
\text { mototaxista }\end{array}$} & \multicolumn{2}{|c|}{ Total } \\
\hline & $\begin{array}{l}\text { N.o de } \\
\text { pessoas }\end{array}$ & $\%$ & $\begin{array}{l}\text { N.O de } \\
\text { pessoas }\end{array}$ & $\%$ & $\begin{array}{l}\text { N.o de } \\
\text { pessoas }\end{array}$ & $\%$ \\
\hline Menos de 1 & 2 & 6,0 & 16 & 21,7 & 18 & 16,7 \\
\hline 1 a 2 & 6 & 17,6 & 9 & 12,1 & 15 & 13,9 \\
\hline 3 a 4 & 5 & 14,7 & 9 & 12,1 & 14 & 13,0 \\
\hline 5 a 10 & 17 & 50,0 & 40 & 54,1 & 57 & 52,8 \\
\hline Mais de 10 & 4 & 11,7 & 0 & 0,0 & 4 & 3,7 \\
\hline Total & 34 & 100,0 & 74 & 100,0 & 108,0 & 100,0 \\
\hline
\end{tabular}

Fonte: Trabalho de campo, 2008.

\footnotetext{
152 É preciso ressaltar que deixar de ser assalariado formal não implica, necessariamente, adentrar o setor informal e que a informalidade como conjunto de práticas que descumpre algum aspecto da legislação vigente é também uma característica presente no chamado setor organizado das ocupações não-agrícolas.

${ }^{153}$ Um exemplo é o salário dos motoboys que é, pelo acordo coletivo da categoria no período 2008/2009 de R\$ 544,00 reais. Auxiliares de produção, de serviços gerais, de escritório, balconistas e entregadores ganhavam em 2007 valores entre $\mathrm{R} \$ 400,00$ e $\mathrm{R} \$ 550,00$, ou seja, valores próximos do salário mínimo regional do Paraná, conforme levantamento preliminar no SINE de Londrina.
} 
Em algumas entrevistas, como a do Sr. E. de 30 anos de idade, ex-funcionário de empresa de transportes coletivos da cidade e que, há 8 anos trabalha em uma das centrais da zona norte de Londrina, fica muito claro que a transição para o Moto Táxi se fez graças à insatisfação com os empregos anteriores:

"Hoje em dia não compensa mais você trabalhar registrado. Eu
trabalhava de cobrador, fazia um horário doido lá, um horário
maluco lá, pra ganhar seiscentos e oitenta real na carteira. Aqui se
eu tiver um compromisso: ir no cartório, comprar uma coisa na
loja, levar a mulher no médico eu posso intercalar no trabalho. Por
exemplo vou levar alguém da família no médico, chega lá eu pego
uma corrida e aqui a gente trabalha com o rádio também" (SR. E.
motoaxista, Trabalho de campo, 2008).

Segundo o entrevistado, apesar de trabalhar um número de horas bem maior do que nos antigos empregos, o fato de poder dispor de seu tempo de outra maneira, descansar entre uma corrida e outra e intercalar o trabalho com a necessidade de resolver problemas pessoais foi um dado adicional para sua decisão de permanecer no moto táxi.

Da mesma forma, alguns outros entrevistados como o Sr. R. da Central Rota 99 na região Central, dissera que "ter sempre um dinheirinho na mão ajuda a poder pagar as contas, não fico preso aquele salário, se aperta posso trabalhar a noite, no domingo...". Essa parece ser também a disposição de um versátil proprietário de estabelecimento que vende artigos de vestuário no Camelódromo que, com apenas 27 anos de idade, já foi empacotador, operador de caixa em um grande supermercado, cabeleireiro e auxiliar de mecânico de automóveis. Insatisfeito com sua última função como vendedor de cartões de uma grande rede varejista da cidade decidiu, após um breve tempo vendendo roupas na feira, instalar-se no Camelódromo onde considera que prosperou, pois já abriu um segundo estabelecimento em sociedade com sua namorada.

O rendimento bruto obtido no Moto Táxi ou no Camelódromo, que em geral é mais elevado do que o de atividades anteriores, é o fator decisivo da avaliação positiva das atividades atuais, más há outros. Para muitos entrevistados "ter menos dor de cabeça e 
menos medo de ficar na rua" (SR, L da central Rota 99), isto é, não deixar sua vida "depender tanto de decisão dos outros" também tem seu peso na avaliação dos que trabalham por conta própria. Há também a percepção de que as atividades, tanto o Moto Táxi como o Camelódromo, são bem sucedidas, que a cidade hoje não vive sem os comerciantes do Camelódromo ou os mototaxistas e que ambas têm potencial para crescer.

A insatisfação, porém, não se manifesta apenas em relação a empregos e ocupações anteriores. Ela também aparece nas falas de diversos entrevistados com relação à ocupação atual. Um dos elementos centrais dessa forma de sentir e avaliar as atividades exercidas atualmente é o temor de aquilo em que se trabalha "não valha a pena".

Alguns entrevistados que atualmente são funcionários de estabelecimentos do Camelódromo repassaram o negócio para parentes próximos. Para essas pessoas ser funcionário permite ter direitos trabalhistas e assim reduzir os riscos a que se está sujeito no trabalho autônomo. Também pesou na transferência do negócio o fato de não ter que tomar decisões arriscadas o tempo todo. Esse foi o caso do Sr. R. migrante nordestino de 53 anos de idade, que já foi metalúrgico e vendedor ambulante. Ele que chegou a ser proprietário de um estabelecimento no Camelódromo durante pouco mais de um ano, preferiu "passá-lo adiante" e trabalhar para a cunhada que atua no mesmo ramo e possui outros estabelecimentos no Camelódromo.

Para o Sr. H. mototaxista da central Ouro Verde na zona norte, de 29 anos de idade, que já foi vendedor viajante e entregador e nunca trabalhou com carteira assinada, uma oportunidade de emprego seria muito bem vinda, principalmente "prá ter os direitos".

Como se pode constatar a insatisfação está presente entre os trabalhadores do serviço de Moto Táxi e entre os pequenos comerciantes do Camelódromo de Londrina. Em geral a insatisfação advém das preocupações com um futuro incerto: acidentes, prestação da 
moto, movimento fraco, fiscalização da receita federal, aluguel caro, não ter direitos (aposentadoria, décimo terceiro, férias).

A permanência dos trabalhadores nas atividades por conta própria sugere que devemos ter alguma desconfiança quanto aos números, em geral comemorados que, vez por outra, indicam aumento no número de empregos formais. Esses empregos podem até ser importantes para minimizar os problemas de quem está procurando um emprego, mas não são suficientes para que, mesmo os insatisfeitos, troquem a ocupação nas atividades por conta própria por empregos formais de remuneração imediata menor do que a obtida no Moto Táxi ou no Camelódromo.

A permanência das pessoas em atividades por conta própria, ao lado da geração de empregos formais de baixa de remuneração, parece sugerir que a eventual melhora na qualidade dos empregos convive com a "instalação na precariedade" de que fala Robert Castel (1998). 


\section{5 - Trajetórias dos trabalhadores do circuito inferior no mercado de trabalho e escolaridade}

As atividades exercidas pelos trabalhadores do circuito inferior em Londrina antes de ingressar na atividade atual eram, em geral, funções que não requeriam grande qualificação e que estavam sujeitas à alta rotatividade. As tabelas a seguir apresentam uma pequena amostra das funções exercidas anteriormente por trabalhadores do circuito inferior com diferentes idades.

Tabela 8

Londrina: funções exercidas anteriormente pelos mototaxistas e grau de escolaridade, 2008.

\begin{tabular}{|c|c|c|c|}
\hline Mototaxistas & $\begin{array}{l}\text { Idade } \\
\text { (anos) }\end{array}$ & Atividades em que já trabalhou & Escolaridade \\
\hline E. & 21 & Ajudante em Lava Rápido & Ensino Médio Incompleto \\
\hline J. E. & 24 & $\begin{array}{l}\text { Auxiliar de produção em fábrica de } \\
\text { ferragens, Servente, Jardineiro }\end{array}$ & Ensino Médio Completo \\
\hline $\mathrm{R}$. & 26 & $\begin{array}{l}\text { Carroceiro, Auxiliar de limpeza, } \\
\text { Montador de móveis, Tapeceiro, } \\
\text { Carregador no CEASA, Entregador }\end{array}$ & Ensino Fundamental Completo \\
\hline $\mathrm{R}$. & 29 & $\begin{array}{l}\text { Auxiliar de pedreiro, Auxiliar de } \\
\text { produção, Vigilante }\end{array}$ & Ensino Fundamental Completo \\
\hline A. & 30 & $\begin{array}{l}\text { Digitador, Segurança, Auxiliar } \\
\text { administrativo, Jateador }\end{array}$ & Ensino Fundamental Completo \\
\hline C. & 32 & $\begin{array}{l}\text { Agricultor, Encarregado de Laticínio, } \\
\text { Servente de pedreiro }\end{array}$ & Ensino Médio Incompleto \\
\hline R. & 34 & $\begin{array}{l}\text { Cobrador de ônibus, Motorista, Auxiliar } \\
\text { de mecânico de autos }\end{array}$ & Ensino Fundamental Completo \\
\hline $\mathrm{F}$. & 39 & $\begin{array}{l}\text { Técnico de refrigeração, Eletricista } \\
\text { industrial, Mecânico de manutenção }\end{array}$ & Ensino Fundamental Completo \\
\hline L. & 40 & Pedreiro, Carpinteiro, Agricultor & Ensino Médio Completo \\
\hline J. & 42 & Caminhoneiro, Garçom & $\begin{array}{l}\text { Ensino Fundamental } \\
\text { Incompleto }\end{array}$ \\
\hline P. & 44 & $\begin{array}{l}\text { Indústria de malhas e confecções, } \\
\text { Pedreiro, Eletricista }\end{array}$ & Ensino Médio Completo \\
\hline M. & 47 & $\begin{array}{l}\text { Torneiro mecânico, Mecânico } \\
\text { Industrial, Pintor de autos, Funileiro }\end{array}$ & Ensino Médio Completo \\
\hline S. & 57 & $\begin{array}{l}\text { Agricultor, Ajudante de motorista, } \\
\text { Motorista de transportadora }\end{array}$ & Ensino Médio Completo \\
\hline J. & 63 & $\begin{array}{l}\text { Operador de máquinas agrícolas, } \\
\text { Auxiliar de produção, Operador de } \\
\text { máquinas industriais }\end{array}$ & $\begin{array}{l}\text { Ensino Fundamental } \\
\text { Incompleto }\end{array}$ \\
\hline
\end{tabular}

Fonte: Trabalho de campo, 2008 
Tabela 9

Proprietários no Camelódromo: funções anteriores e escolaridade, 2008.

\begin{tabular}{|c|c|c|c|}
\hline $\begin{array}{l}\text { Proprietários no } \\
\text { Camelódromo }\end{array}$ & $\begin{array}{l}\text { Idade } \\
\text { (anos) }\end{array}$ & Atividades em que já trabalhou & Escolaridade \\
\hline J. & 21 & $\begin{array}{l}\text { Operador de telemarketing, Telefonista e } \\
\text { Secretária }\end{array}$ & $\begin{array}{l}\text { Ensino Médio } \\
\text { Incompleto }\end{array}$ \\
\hline L. & 24 & Metalúrgico & $\begin{array}{l}\text { Ensino Superior } \\
\text { Incompleto }\end{array}$ \\
\hline M. & 24 & Garçom, Copeiro, Atendente & $\begin{array}{l}\text { Ensino Médio } \\
\text { Completo }\end{array}$ \\
\hline M. & 26 & Vendedor temporário & $\begin{array}{l}\text { Ensino Fundamental } \\
\text { Completo }\end{array}$ \\
\hline E. & 27 & $\begin{array}{l}\text { Cabeleireiro, Empacotador, Mecânico, } \\
\text { Operador de caixa no comércio }\end{array}$ & $\begin{array}{l}\text { Ensino Médio } \\
\text { Completo }\end{array}$ \\
\hline M. & 29 & $\begin{array}{l}\text { Vendedor de móveis, Supervisor de loja de } \\
\text { móveis, Gerente de loja de móveis }\end{array}$ & $\begin{array}{l}\text { Ensino Médio } \\
\text { Completo }\end{array}$ \\
\hline R. & 30 & Doméstica, Auxiliar de costura & $\begin{array}{l}\text { Ensino Médio } \\
\text { Completo }\end{array}$ \\
\hline $\mathrm{T}$. & 32 & Vendedora & $\begin{array}{l}\text { Ensino Médio } \\
\text { Completo }\end{array}$ \\
\hline $\mathrm{K}$ & 32 & Garçonete, Balconista em restaurante & $\begin{array}{l}\text { Ensino Médio } \\
\text { Completo }\end{array}$ \\
\hline E. & 38 & Comerciante & $\begin{array}{l}\text { Ensino Médio } \\
\text { Completo }\end{array}$ \\
\hline M.E. & 41 & Doméstica & $\begin{array}{l}\text { Ensino Médio } \\
\text { Completo }\end{array}$ \\
\hline C. & 45 & Vendedor & $\begin{array}{l}\text { Ensino Médio } \\
\text { Incompleto }\end{array}$ \\
\hline V. & 49 & Proprietária de pastelaria & $\begin{array}{l}\text { Ensino Médio } \\
\text { Completo }\end{array}$ \\
\hline $\mathrm{D}$ & 51 & $\begin{array}{l}\text { Metalúrgico, Vendas em Supermercado e } \\
\text { Distribuidor de Calçados }\end{array}$ & Não estudou \\
\hline R. & 53 & Vendedor ambulante e Metalúrgico & $\begin{array}{l}\text { Ensino Fundamental } \\
\text { Completo }\end{array}$ \\
\hline A. & 55 & Gerente comercial & $\begin{array}{l}\text { Ensino Superior } \\
\text { Completo }\end{array}$ \\
\hline
\end{tabular}

Fonte: Trabalho de campo, 2008

Tabela 10

Motoboys: funções anteriores e escolaridade, 2008.

\begin{tabular}{|c|c|c|c|}
\hline Motoboys & $\begin{array}{l}\text { Idade } \\
\text { (anos) }\end{array}$ & Atividades em que já trabalhou & Escolaridade \\
\hline E. & 19 & $\begin{array}{l}\text { Auxiliar administrativo, Balconista, } \\
\text { Auxiliar de Padeiro }\end{array}$ & Ensino Médio Incompleto \\
\hline T. & 21 & $\begin{array}{l}\text { Caixa de Supermercado, Balconista, } \\
\text { Promotor de Vendas }\end{array}$ & Ensino Médio Completo \\
\hline A. & 23 & $\begin{array}{l}\text { Auxiliar de Produção, Auxiliar de } \\
\text { Serviços Gerais, Garçom }\end{array}$ & Ensino Médio Incompleto \\
\hline J. & 26 & $\begin{array}{l}\text { Metalúrgico, Auxiliar em Lavanderia } \\
\text { Industrial }\end{array}$ & Ensino Fundamental Completo \\
\hline C. & 28 & $\begin{array}{l}\text { Balconista em Depósito, Auxiliar de } \\
\text { produção, Ajudante de Motorista de } \\
\text { Caminhão }\end{array}$ & Ensino Médio Incompleto \\
\hline $\mathrm{F}$. & 31 & $\begin{array}{l}\text { office-boy, Encarregado de Depto. } \\
\text { Pessoal }\end{array}$ & Ensino Médio Incompleto \\
\hline L. & 33 & $\begin{array}{l}\text { Entregador em Supermercado, } \\
\text { Atendente em Agencia de turismo, } \\
\text { Restaurante no Japão }\end{array}$ & Ensino Médio Completo \\
\hline C. & 38 & Padeiro, Reciclador na Coleta Seletiva & Ensino Fundamental Completo \\
\hline W. & 43 & Frentista, Agricultor & Ensino Médio Completo \\
\hline D. & 46 & Agricultor, Pedreiro & Ensino Fundamental Completo \\
\hline
\end{tabular}

Fonte: Trabalho de campo, 2008 
As funções citadas com maior freqüência pelos entrevistados são ligadas à atividade industrial, tanto a indústria de transformação como a construção civil. No total as atividades industriais fizeram parte da trajetória de $38 \%$ do total de entrevistados ${ }^{154}$.

As funções ligadas ao comércio, especialmente as de vendedor, balconista, caixa ou entregador, também foram freqüentes entre os trabalhadores do circuito inferior. No Camelódromo, por exemplo, 22 entrevistados num total de 34 disseram ter trabalhado como vendedor, caixa, balconista ou auxiliar de serviços gerais em algum estabelecimento comercial. Outras 4 pessoas que adquiriram pontos comerciais no Camelódromo tiveram pastelarias, lojas de roupa, restaurantes e um cybercafé ${ }^{155}$. No total aproximadamente $30 \%$ das pessoas entrevistadas exerceu funções ligadas ao comércio.

As funções exercidas no âmbito do chamado "terciário banal", como segurança, vigilante, limpeza, frentista, mecânico de autos, garçom, motoristas de caminhão e cobradores de ônibus também foram freqüentes na trajetória dos trabalhadores do circuito inferior, especialmente entre os motoboys com mais de 25 anos de idade. Algumas funções modernas como a de operador de telemarketing, de call Center ou em atividades hegemônicas como a de bancário e ainda ex-funcionários públicos completam a lista. As atividades exercidas no âmbito do terciário fizeram parte da trajetória de 33\% dos trabalhadores do circuito inferior.

As atividades exercidas no âmbito da agricultura também foram mencionadas pelos entrevistados, porém com freqüência muito menor do que as atividades urbanas. Apenas $8 \%$ dos entrevistados mencionou funções ligadas ao campo.

Constatamos que não há uma predominância efetiva de um ou outro setor de atividade (indústria, comércio ou serviços) na origem

\footnotetext{
${ }^{154} \mathrm{O}$ total de entrevistados que respondeu a essa pergunta foi de 160 trabalhadores.

155 Após os dois primeiros anos em que houve uma transição da fase em que a Prefeitura controlou parte da administração do Camelódromo para a fase atual em que toda administração ficou a cargo da ONG Canaã, foram feitas reformas como o ar condicionado, a escada rolante para melhorar a fluência das pessoas para o segundo pavimento e a abertura de uma modesta praça de alimentação e readaptação de alguns boxes próximos a ela, inclusive com área para o cyber café.
} 
dos trabalhadores do circuito inferior em Londrina. A característica comum que chamou nossa atenção foi o tipo de ocupação exercido mais do que o setor, considerado em termos tradicionais. Em geral, seja na indústria, no comércio ou nos serviços, as funções exercidas resultam de posições na divisão do trabalho que, em momentos de crise, são enxugadas ou redistribuídas entre os que ficam na empresa.

A facilidade de contratar e demitir pessoas favorecida pela legislação implantada nos anos 1970, com a criação do Fundo de Garantia por Tempo de Serviço (FGTS) as recentes aberturas para contratos em tempo parcial combinados a períodos de formação (treinamentos) dos trabalhadores desempregados contribuem para acelerar a rotatividade da força de trabalho. A fragilidade dos vínculos empregatícios das posições na divisão do trabalho ocupadas pelos entrevistados parece ser um fator mais importante na explicação do volume e do ritmo de trocas de emprego que caracterizam as trajetórias dos trabalhadores do circuito inferior no mercado de trabalho do que o setor em que a função foi exercida.

O exame da trajetória dos trabalhadores do circuito inferior no mercado de trabalho de Londrina indica que, para as pessoas que completaram o ensino médio há um leque maior de opções. As funções de encarregado, gerente, supervisor, etc. mencionadas pelos entrevistados estão quase sempre ligadas a pessoas que cursaram o ensino médio ou o curso superior (completos e incompletos).

A escolaridade dos trabalhadores nas três atividades pesquisadas apresentou a distribuição representada nos gráficos a seguir. 
Gráfico 19

Grau de escolaridade dos trabalhadores do Camelódromo (\%)

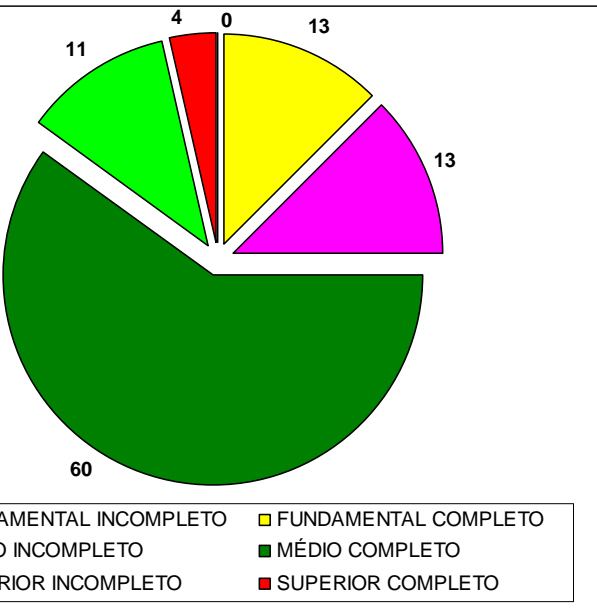

Fonte: Trabalho de campo, 2008

Gráfico 20

Grau de escolaridade dos mototaxistas (\%)

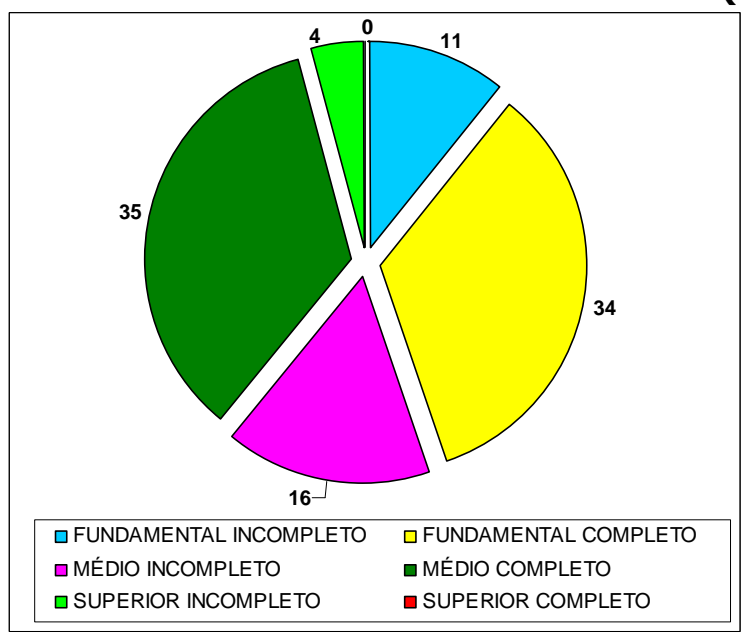

Fonte: Trabalho de campo, 2008

Gráfico 21

Grau de escolaridade dos motoboys (\%)

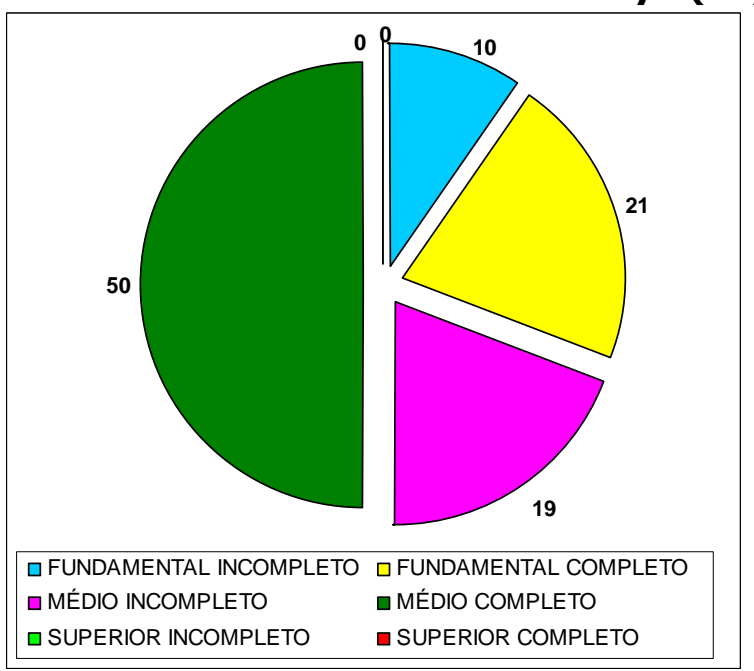

Fonte: Trabalho de campo, 2008 
Nas três atividades predominam pessoas que concluíram o ensino médio. Somando aqueles que têm o ensino médio completo às pessoas que cursaram pelo menos uma série do ensino médio (ensino médio incompleto), temos mais da metade dos entrevistados nas três categorias. A falta de escolaridade ou escolaridade insuficiente não é exatamente uma característica marcante dos trabalhadores do circuito inferior em Londrina no período atual.

Considerando a totalidade dos entrevistados a grande maioria $(64 \%)$ estudou até o ensino médio. Praticamente a metade, isto é, $48 \%$ dos entrevistados concluíram esse nível de ensino e $16 \%$ possuem ensino médio incompleto.

Entre os homens $57,5 \%$ tem até 30 anos e entre as mulheres o percentual é de $80 \%$. Esse grupo também possui mais anos de escolaridade. Dentre os trabalhadores (as) com idade até 30 anos $77 \%$ estudaram até o ensino médio, sendo que $55 \%$ concluíram o ensino médio e $22 \%$ possuíam o ensino médio incompleto. Nesse grupo estão também os que estão estudando atualmente: 20 pessoas, sendo 11 no ensino superior, 3 no ensino fundamental supletivo e 6 no ensino médio supletivo e profissionalizante.

A escola pública foi o lugar em que a quase totalidade dos entrevistados teve acesso à escolaridade. Mais de $90 \%$ dos entrevistados estudaram em escolas públicas. Esses dados fazem refletir sobre a escolaridade como elemento de mobilidade social. Há novas formas de escassez, a exemplo do ensino público e gratuito de qualidade, com as quais os jovens têm de se defrontar. $O$ ensino público de qualidade tem reflexos sobre o desafio que é, para a maioria da população, encontrar uma ocupação no contexto da economia urbana no período atual. 


\section{CAPÍtULOO 6}

\section{O circuito inferior na divisão do trabalho: aceleração contemporânea, horizontalidade e articulação de escalas}

\section{1 - A aceleração contemporânea e a circulação de mercadorias e pessoas em Londrina}

Uma das condições da permanência e funcionamento do Camelódromo, do Moto Taxi e das Entregas Urbanas ao longo de mais de uma década, tem sido a possibilidade de estabelecer uma complementaridade eficaz em relação a um variado conjunto de outras atividades econômicas presentes na cidade. Essas atividades pertencem tanto ao próprio circuito inferior, como ao circuito superior e ao superior marginal.

Outra condição é a possibilidade de atender as necessidades crescentes da circulação de pessoas com baixos rendimentos e de mercadorias de consumo de massa, com pequeno tamanho e de preços relativamente baixos.

A intensificação da circulação de pessoas, mercadorias e informações entre cidades e também no interior das cidades está diretamente ligada ao conjunto de transformações promovidas pela expansão do meio técnico-científico-informacional, característica marcante do período atual. Além da integração do território, da identificação entre mercado e território, também a crescente fluidez do território (SANTOS, 1996 , p. 39) contribui para o aumento dos fluxos no espaço intraurbano, especialmente nas cidades do Sul e Sudeste do país. Nessa parte do país a mobilidade do capital e do trabalho sustentada por diversos tipos de redes, alia-se a um conhecimento mais refinado e atualizado dos lugares, estimulando novas estratégias de localização da parte de grandes grupos empresariais ligados à produção industrial, aos serviços e ao comércio. 
As novas topologias desses atores hegemônicos levam a novas especializações das tarefas no território e, conseqüentemente, ao aprofundamento da divisão territorial do trabalho e a uma interação constante com o aumento da circulação.

Estamos diante de novo patamar, quanto à divisão territorial do
trabalho. Esta se dá de forma mais aprofundada e esse
aprofundamento leva a mais circulação e mais movimento em
função da complementaridade necessária. Mais circulação e mais
movimento permitem de novo aprofundamento da divisão
territorial do trabalho, o que, por sua vez, cria mais especialização
do território. O círculo, nesse caso virtuoso (ou será vicioso?), se
amplia. (SANTOS, 1996, p.41)

$\mathrm{Na}$ condição de "nós de uma divisão de trabalho à escala mundial" (SILVEIRA, 2002, p.15) as cidades médias passam a abrigar áreas especializadas destinadas a formas modernas de produção e de circulação tais como: distritos industriais, parques tecnológicos, incubadoras de empresas, portos secos, também chamados de Estações Aduaneiras do Interior, shopping centers e mega empreendimentos que combinam shopping centers, edifícios para escritórios e para habitação, como no caso do "projeto marco zero" em Londrina.

A seletividade presente na escolha das cidades onde se constroem grandes fixos especializados, dedicados à contínua intensificação do consumo como os shopping centers, expressa o tipo de especialização urbana ligada à divisão territorial do trabalho, que tem reflexos na circulação intra urbana.

Em Londrina a presença do Shopping Center Catuaí, redefiniu a estrutura urbana e também a centralidade no arranjo espacial da cidade e da região (SILVA, 2002). As transformações da centralidade em Londrina acompanham a maior complexidade de sua economia urbana e se expressam na formação de subcentros e na articulação entre fluxos dados na escala do espaço intra-urbano com fluxos definidos na escala da rede urbana. O Shopping Catuaí, um dos novos subcentros, por reunir (centralizar) em um ambiente climatizado e controlado, lojas de departamentos, supermercados, cinemas, praça de alimentação, estacionamento, etc., tornou-se ponto de convergência de pessoas de 
todas as partes da cidade, assim como de municípios próximos, e até mesmo de outros não tão próximos, como alguns situados no interior paulista (SILVA, 2002, p. 80)

Os serviços especializados nas áreas de saúde e educação superior também atuam como fatores de polarização e atração de empresas e pessoas, que procuram Londrina para trabalhar e fazer negócios. Recentemente, a possibilidade de ter acesso a aulas baseadas em teleconferências e voltadas à preparação de candidatos para concursos públicos, especialmente na área das carreiras jurídicas, tem atraído pessoas de outras cidades para Londrina. Também a concentração de cursos técnicos e superiores na área de tecnologias da informação, bem como de empresas especializadas nessa área, têm tido o mesmo efeito de polarização.

Internamente, isto é, com relação à estrutura urbana, concentrações industriais, laboratórios, hospitais, universidades, shopping centers, concessionárias de veículos, além do conjunto de estabelecimentos comerciais e de serviços reunidos no Centro Principal, contribuem para geração e ampliação de fluxos cotidianos de mercadorias, pessoas e informações. Esses fluxos, por sua vez, podem se desdobrar em deslocamentos que requerem serviços como os que são prestados pelo Moto taxi ou pelas empresas de entrega urbana, capazes de atender a essas demandas.

A fragmentação do espaço urbano, que se aprofunda com a expansão físico-territorial da cidade e com a formação de novos centros, aumenta exponencialmente as necessidades de circulação. Financiamentos a perder de vista lubrificam o consumo de celulares, automóveis, motocicletas, apartamentos e casas. O consumo, um dos motores da urbanização, contribui para que, simultaneamente, aconteça a expansão horizontal das cidades e sua verticalização, adensando áreas artificialmente valorizadas e produzindo pontos de estrangulamento da circulação urbana. 
A fragmentação que resulta desse conjunto de processos impõe às cidades gastos crescentes com infraestrutura viária, os quais realimentam a especulação imobiliária. O Estado, em seus vários níveis de existência e escalas de atuação, complementa a ação das empresas e impulsiona a socialização capitalista.

Entenda-se por socialização capitalista a criação de capitais
comuns, e meios coletivos à disposição do processo produtivo. É
socialização pelo fato de que não são os capitais individuais que a
devem empreender diretamente; é capitalista porque os
beneficiários são poucos, segundo uma hierarquia que vem de seu
poder enquanto capitalista, isto é, de sua capacidade de utilizar
produtiva e especulativamente as infraestruturas financiadas por
meio de impostos, com esforço coletivo, isto é, mediante
contribuição social. A socialização capitalista é, pois, e, sobretudo,
um processo de transferência de recursos da população como um
todo para algumas pessoas e firmas. Trata-se, como dito antes de
um processo seletivo, que atinge diferentemente os atores
econômicos, o que faz do Estado um motor de desigualdades, já
que, por esse meio, favorece concentrações e marginalizações.
(SANTOS, 1994, p. 122)

Uma cidade média como Londrina, a segunda maior do

Paraná e centro de uma dinâmica aglomeração urbana não-metropolitana, pode ser entendida como um capital social indivisível (SANTOS, 1994a), que abriga uma intensa divisão do trabalho, processo que se torna mais intenso pela concentração demográfica e econômica propiciadas pela aglomeração. Por sua vez, uma divisão do trabalho intensa, atua como um catalisador para a socialização capitalista e a segmentação do mercado.

A marcha do capitalismo é, também, a marcha para a socialização capitalista, graças à acentuação da divisão do trabalho e à necessidade, igualmente crescente, de coordenação. A cooperação é a outra face da divisão do trabalho. [...]

As grandes cidades aceleram o processo, em virtude de, nelas, a divisão do trabalho ser maior; e as grandes cidades dos países subdesenvolvidos o aceleram ainda mais, graças a diversos fatores. (SANTOS, 1994, p. 123)

A concentração demográfica, aliada a um meio construído extenso e diversificado e uma intensa divisão de trabalho, possibilita a segmentação do mercado que se expressa em um elevado grau de interdependência entre empresas de diferentes dimensões e capacidades (SILVEIRA, 2004, p.11). Dessa forma Londrina reúne as condições para o 
florescimento de um ativo circuito inferior e também de um circuito superior marginal composto por pequenas e médias empresas industriais, especialmente nos segmentos de confecção e alimentos, e também de serviços, tanto serviços complementares à atividade agrícola como outros ligados às tecnologias da informação.

A necessidade de fluxos que retomem a ligação desfeita ou dificultada pela dispersão, que reúnam o que a divisão social do trabalho separou, alimenta a formação de novas atividades, inclusive no circuito inferior. Aprofundando a divisão do trabalho na cidade as três atividades estudadas participam da cooperação urbana, por meio da circulação de mercadorias e de pessoas, processos cujas intensidades têm relação com a inserção de Londrina na rede urbana e na divisão territorial do trabalho.

Nesse sentido, a fragmentação do tecido urbano, a contínua expansão físico territorial de Londrina (verticalização e expansão das periferias), de par com a intensificação dos consumos e a segmentação do mercado, promovem a demanda crescente por circulação. Isso abarca o transporte de pessoas e serviços de entregas, especialmente a domicílio e também o tempo gasto nessas atividades. As mudanças nos hábitos de consumo, os constrangimentos do tráfego, cada vez mais intenso em algumas vias e a comodidade que significa receber em casa todo tipo de mercadoria de pequeno volume, de alimentos a remédios, de aparelhos eletrônicos a convites para eventos, fazem proliferar o comércio, central e dos bairros, as empresas de entrega urbana e o serviço de Moto Táxi. 


\section{2 - Circuito inferior e horizontalidade}

Ao contrário do que ocorre com o circuito superior, no circuito inferior a integração à economia urbana se dá localmente (SANTOS, 1979, p. 36). Em Londrina essa característica das atividades do circuito inferior ficou evidenciada pelos nexos entre as três atividades estudadas e o contexto econômico local, ou seja, sua inserção na divisão de trabalho na escala local.

A escala local, isto é, a extensão produzida e definida pela existência e não por uma concepção de base geométrica (SILVEIRA, 2006, p.88) se refere, no caso das três atividades estudadas, às formas do acontecer complementar reveladas pelos conteúdos geográficos dessas atividades: as ações e os objetos nelas envolvidos.

A existência e o funcionamento do Camelódromo, do Moto Taxi e das Empresas de Entregas Urbanas dependem da relação que mantêm com empresas e indivíduos localizados em Londrina e municípios mais ou menos próximos. Isso significa que, pelas reduzidas dimensões e escassa capitalização que caracteriza as atividades estudadas, a proximidade e a contigüidade desempenham papéis importantes em sua reprodução. Esse dado associado à dependência que manifestam em relação às outras empresas da cidade as inscreve no contexto do acontecer complementar, que para além das relações entre cidade e campo, ou das relações entre cidades (SANTOS, 2004, p.166), também se revela nas relações entre os circuitos da economia urbana.

A relação umbilical das três atividades com o lugar reforça sua caracterização como atividades pertencentes ao circuito inferior. Nas três atividades estudadas observamos diferentes graus de dependência em relação ao conjunto da economia urbana em Londrina. O maior grau de dependência se dá nas Empresas de Entregas Urbanas, cujos principais clientes estão concentrados em Londrina, especialmente na área central 
da cidade. Esse grau de dependência é ligeiramente menor no Moto Táxi, que também atende demandas de pequenas empresas de municípios vizinhos e outros próximos. É ainda um pouco menor no caso do Camelódromo, que conta com clientela proveniente até mesmo de outras unidades da federação. Sendo assim, consideramos a dependência em relação à economia urbana como inversamente proporcional à área de mercado de cada atividade, definindo esta última a partir da localização e distribuição das empresas e indivíduos que primariamente consomem as mercadorias e serviços das três atividades.

Para desenvolver esses argumentos analisamos a seguir as formas de complementaridade entre as três atividades e o conjunto da economia urbana em Londrina. 


\subsection{1 - O Camelódromo: complementaridade e cooperação}

Procuramos analisar as possíveis relações de estabelecimentos do Camelódromo e do próprio Camelódromo com outras atividades econômicas da cidade. As empresas que prestam serviços ao Camelódromo são as de segurança, manutenção da escada rolante, telefonia e acesso a internet (Sercomtel e GVT). O serviço mais freqüentemente contratado pelos estabelecimentos é o de um contador. Em praticamente todos os estabelecimentos, há o uso dos serviços desse profissional, indicando a dificuldade que existe para se manter dentro das exigências normativas do fisco e de outras instâncias da administração pública.

Em 53\% dos estabelecimentos que afirmaram fazer divulgação, ocorre a contratação de gráficas para confecção de cartões e serviços de som móveis, que por meio de carros e motos divulgam as ofertas pelas ruas. Alguns estabelecimentos que adquirem mercadorias em São Paulo contratam transportadoras para trazer as mercadorias que abastecem o estabelecimento. Em apenas 20\% dos estabelecimentos ocorre, de forma esporádica, a solicitação do serviço de motoboys ou mototaxistas para realizar entregas.

Com relação à aquisição das mercadorias procuramos verificar qual a participação de outras empresas situadas em Londrina e cidades vizinhas no fornecimento das mercadorias vendidas no Camelódromo, visando a identificação de aspectos quantitativos e qualitativos nos nexos entre o Camelódromo e o conjunto da economia urbana. As respostas dadas a essa questão permitiram observar a seguinte distribuição, resumida na tabela a seguir. 
Tabela 11

Camelódromo: origem das mercadorias, 2008.

\begin{tabular}{|c|c|c|}
\hline $\begin{array}{c}\text { Origem das } \\
\text { mercadorias }\end{array}$ & $\begin{array}{c}\text { N.o de } \\
\text { Estabelecimentos }\end{array}$ & $\%$ \\
\hline Apenas Londrina & 19 & 23,46 \\
\hline $\begin{array}{c}\text { Londrina e outras } \\
\text { localidades }\end{array}$ & 19 & 23,46 \\
\hline $\begin{array}{c}\text { Não compram em } \\
\text { Londrina }\end{array}$ & 41 & 50,62 \\
\hline Sem informação & 2 & 2,47 \\
\hline Total & $\mathbf{8 1}$ & $\mathbf{1 0 0 , 0 0}$ \\
\hline
\end{tabular}

Fonte: Trabalho de Campo, 2008

Verificamos que há um relativo equilíbrio na participação de Londrina e de outras localidades no fornecimento das mercadorias comercializadas no Camelódromo, uma vez que $47 \%$ dos estabelecimentos afirmaram realizar compras de suas mercadorias na cidade.

Analisando quais produtos eram comercializados pelos 38 estabelecimentos que afirmaram adquirir seus produtos em Londrina, constatamos que predominam os que se dedicam ao comércio varejista de DVD's, CD's e Games, com 31,6\%. Destacam-se também os estabelecimentos que comercializam artigos para vestuário e acessórios, como Bolsas e cintos, com 18,4\%, e os que vendem acessórios para aparelhos celulares (novos e usados), também com 18,4\%, e os que comercializam eletrodomésticos de áudio e vídeo com $13,2 \%{ }^{156}$.

Podemos dizer, a partir desses dados, que um dos pontos de ligação do Camelódromo com outras atividades econômicas radicadas em Londrina passa pela comercialização de DVD's, mercadoria de baixo custo e com forte apelo de consumo, cuja produção mergulha em uma intrincada rede clandestina de obtenção das matrizes.

Atualmente, Londrina abriga as chamadas fábricas de DVDs, responsáveis pela multiplicação da oferta crescente de filmes, shows e músicas em discos a laser. O conjunto de técnicas implicadas na

\footnotetext{
${ }^{156}$ Os outros estabelecimentos vendem uma variedade de produtos como ferramentas, suprimentos para informática, brinquedos, cosméticos, etc e totalizam mais $18,4 \%$ dos 38 estabelecimentos que adquirem suas mercadorias em Londrina.
} 
reprodução de sons e imagens a partir do laser disseminou-se rapidamente com o barateamento dos aparelhos domésticos que operam com base nessa tecnologia, capazes de reproduzir tanto filmes como músicas com alta qualidade. Se o fogão teve sua difusão a partir de meados dos anos 1980 (SANTOS e SILVEIRA, 2001) a passagem dos aparelhos de reprodução de sons e imagens baseados em fitas magnéticas para aparelhos que utilizam o laser e sua correspondente difusão, remonta aos últimos dez ou quinze anos.

Com base no trabalho de campo verificamos que em $94 \%$ dos domicílios do conjunto de trabalhadores do circuito inferior de Londrina com os quais tivemos contato ${ }^{157}$, o aparelho de reprodução de DVDs estava presente.

A forte disseminação desses objetos técnicos nos domicílios urbanos não pode ser dissociada da produção e consumo crescentes de sons e imagens que caracteriza o período atual. A modernização acelerada das técnicas implicadas na generalização do consumo de sons e imagens como mercadorias traz consigo a possibilidade da fabricação clandestina e acelerada de milhares de cópias não autorizadas de filmes, shows e músicas viabilizando a segmentação do consumo desses produtos.

Esse processo de fabricação clandestina se deve em parte ao aperfeiçoamento e a compactação dos objetos técnicos que tornam portáteis e de fácil operação computadores potentes equipados com aparelhos de gravação que permitem a produção em série de DVDs e CDs com rapidez e alguma qualidade. Também a facilidade de acesso às fontes originais de filmes e músicas criada pela Internet onde essas fontes circulam de forma clandestina e outras formas de obtenção em estúdios de gravação e filmagem das matrizes usadas para a intensa reprodução desses produtos culturais.

Pelo lado do consumo, o preço de CDs e DVDs originais comprados ou alugados no comércio do circuito superior e superior

\footnotetext{
${ }^{157}$ Dentre os duzentos e sete questionários aplicados a trabalhadores do Camelódromo, mototaxistas e motoboys verificamos que em 195 domicílios, ou seja, 94,2\%, o aparelho de DVD estava presente. Vale lembrar que esse aparelho é condição básica para o consumo dos discos contendo espetáculos cinematográficos e musicais.
} 
marginal torna essas mercadorias inacessíveis à grande parte das famílias de trabalhadores cujos rendimentos são insuficientes até mesmo para fazer frente a necessidades básicas de sobrevivência, como a aquisição de alimentos, água, energia elétrica, etc. Assim perpetuam-se, atualizam-se e intensificam-se fatores que estão na base da existência e funcionamento do circuito inferior.

Diretamente ligada a esse conjunto de fatores, a multiplicação de vendedores ambulantes e pequenos estabelecimentos do Camelódromo de Londrina que comercializam DVDs parece ter fôlego para resistir ás constantes intervenções policiais e outras formas de repressão. Seria isso um indicador de algo mais profundo?

Se as mercadorias são cada vez mais numerosas e abarcam cada vez mais campos da vida, fazendo ecoar a análise de Georg Lukács (2003) a respeito do processo de reificação, é de se esperar que, em algum grau a necessidade criada pela existência dessas novas mercadorias atinja também aqueles que não têm renda disponível para obtê-las pelas formas convencionais. Afinal a generalização da forma mercantil não faz distinção entre os que têm rendimentos suficientes e os que não podem sequer obter o necessário para sobreviver na cidade.

Verificamos, no entanto, que a atividade comercial no Camelódromo não se resume à venda de DVDs chamados "piratas". Por meio do Camelódromo circulam diversos outros produtos adquiridos na cidade como roupas e acessórios, celulares novos e usados, acessórios para celulares, produtos eletrônicos e suprimentos para informática, para os quais, há fornecedores (atacadistas e fábricas) situados em Londrina e Cambé. É o caso de produtos eletrônicos portáteis, suprimentos de informática, confecções, lingeries, brinquedos e outros itens adquiridos em atacadistas da cidade ${ }^{158}$.

\footnotetext{
${ }^{158}$ Foram citadas várias empresas que comercializam produtos eletrônicos portáteis, telefonia, computadores, suprimentos e periféricos para informática, brinquedos. São elas Hayamax Importadora, CS presentes e a Gralha Azul grande atacadista de peças e partes de computadores que comercializa também computadores e periféricos e tem sedes em Londrina e Curitiba. Outras empresas atacadistas como a Leo Cosméticos que atua também como varejista, da Ativa Importadora que fornece produtos variados e a Vest Mania confecções.
} 
Há ainda uma complementaridade importante entre estabelecimentos do Camelódromo e fábricas de pequeno e médio porte instaladas em Londrina e cidades próximas ${ }^{159}$ que produzem lingeries, roupas, bonés, malas e bolsas de tecidos sintéticos, artigos de couro (bolsas, cintos e calçados) e acessórios para celulares. Vale ressaltar que no conjunto, dentre 316 boxes que abrigam os estabelecimentos do Camelódromo de Londrina, um em cada quatro boxes ${ }^{160}$ vendem artigos de vestuário e acessórios.

Em relação aos consumidores que freqüentam os estabelecimentos a esmagadora maioria é da própria cidade. Em 83\% dos estabelecimentos os clientes regulares são principalmente de Londrina, enquanto nos outros $17 \%$ os clientes regulares não estão concentrados em Londrina, mas distribuídos entre Londrina e municípios vizinhos.

Quanto ao gênero não houve identificação de um público específico. Há tanto homens como mulheres entre os clientes. A faixa etária predominante é de jovens, como indicaram 53\% dos entrevistados. Os outros $47 \%$ também apontaram a presença dos jovens entre os compradores, contudo não afirmaram que fossem os principais clientes do estabelecimento. Do ponto de vista da renda dos consumidores, $70 \%$ dos entrevistados responderam que são consumidores de renda média e baixa, confirmando a hipótese de que se trata do público típico do circuito inferior.

Em resumo, a maioria dos consumidores do Camelódromo é de assalariados de Londrina. Cotidianamente, os dias de maior movimento são os primeiros dias do mês, quando grande parte dos assalariados,

\footnotetext{
${ }^{159}$ Foram citadas pequenas e médias fabricantes de Londrina como a Valud Lingeries, Lokau Jeans, Empório do Couro e a Malui Malhas que comercializam parte de sua produção diretamente com estabelecimentos do Camelódromo. Há ainda fornecedores de bonés como a Globex, Seqüencial e a Firezone, fabricantes de bonés e bolsas de materiais sintéticos de Apucarana e outras empresas fabricantes e atacadistas de Maringá como a Oderço.

${ }^{160} \mathrm{O}$ número de estabelecimentos em meados de 2007 era de aproximadamente 300, uma vez que alguns estabelecimentos ocupavam 2 ou mais boxes. Além disso, há um movimento constante de venda de pontos comerciais, aluguel de espaços, mudança de localização interna, etc. Definimos uma base para os cálculos utilizando o número original de boxes para determinar também a participação de cada tipo de produto no conjunto do Camelódromo, já que os boxes originais ainda são uma referencia básica para localização, aluguéis, cobrança de condomínio, etc.
} 
incluindo os funcionários públicos, recebem seus salários, como nos informou o presidente da ONG Canaã, instituição responsável pela administração do Camelódromo ${ }^{161}$. Assim como ocorre com as demais lojas da cidade, as datas comemorativas, como o natal e o dia das mães, são momentos em que aumenta significativamente o movimento de vendas.

Se pelo lado das compras de mercadorias o Camelódromo mantém uma relação intensa com São Paulo e, em menor proporção com o Paraguai, pelo lado das vendas, há uma forte dependência de Londrina, seu principal mercado.

${ }^{161}$ Entrevista realizada em meados de 2007 


\subsection{2 - O Moto Táxi: fluxos intraurbanos, constrangimentos do meio construído e formas de cooperação}

O serviço de Moto Táxi tem no transporte de passageiros sua característica marcante. Em $70 \%$ das 35 Centrais que visitamos esse tipo de corrida abarca entre $60 \%$ e $90 \%$ do total diário das corridas solicitadas. Como conseqüência, a maioria dos mototaxistas tem no transporte de passageiros a principal fonte de seus rendimentos, especialmente entre os que têm menos de 5 anos de atuação.

Gráfico 22

Londrina: mototaxistas segundo o tipo de corrida predominante (\%).

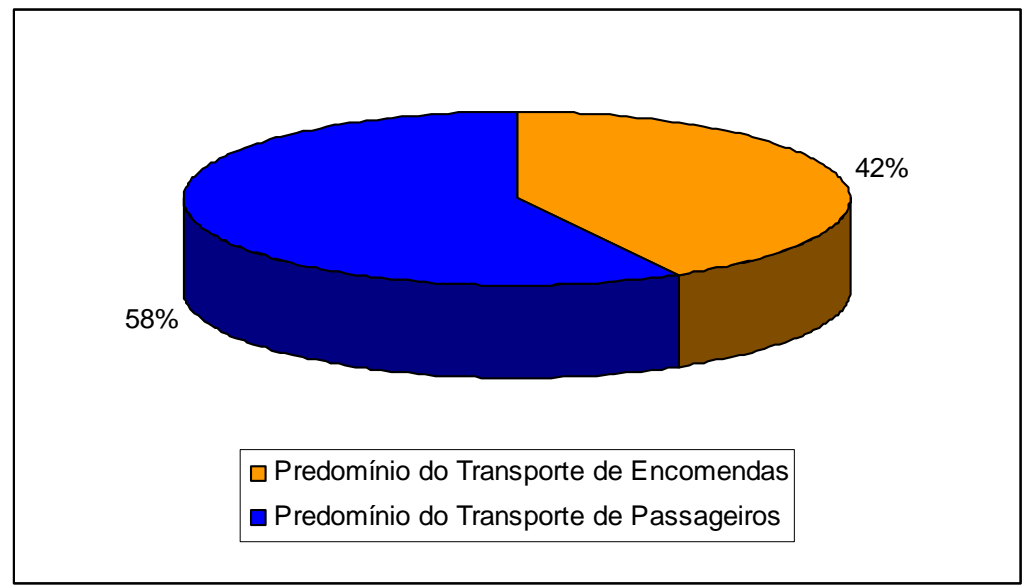

Fonte: Trabalho de campo, 2008.

Em geral, as corridas para transporte de passageiros são motivadas pela necessidade chegar mais depressa ao local de trabalho. Segundo um dos mototaxistas da Celsinho Moto táxi, situada na zona norte, "o pessoal chama a gente quando quer dormir um pouco mais sem chegar atrasado no trabalho". Essa mesma opinião foi manifestada por diversos outros entrevistados de várias Centrais espalhadas na cidade, especialmente as que se localizam a certa distância do Centro Principal ${ }^{162}$. Nada menos que $86 \%$ dos entrevistados (64 mototaxistas) afirmaram que o motivo da solicitação das corridas era chegar ao trabalho pela manhã. 0 segundo motivo mais freqüentemente apontado foi poder pagar contas no

\footnotetext{
${ }^{162}$ O mesmo tipo de afirmação foi feito por mototaxistas das Centrais Rota 66 no extremo leste da cidade, Moto Táxi Cafezal na zona sul e Moto Taxi Vivi na zona norte.
} 
Centro com segurança, deslocando-se diretamente de casa para o banco ou a loja.

Ao longo do dia, os momentos em que há maior concentração de corridas são exatamente aqueles em que os deslocamentos cotidianos entre os locais de residência e trabalho são intensos. O início da manhã entre 6:00 e 9:00 horas, foi apontado por $62 \%$ dos mototaxistas como horário em que há maior número de solicitações de corridas, e o final da tarde, entre 16:00 e 19:00 horas, período apontado por 39\% dos entrevistados. Além desses momentos de pico nos deslocamentos cotidianos também o período da tarde, a partir das 13:00 horas, foi apontado por $25 \%$ dos mototaxistas como momento do dia em que as corridas são freqüentes.

Esses dados sobre os horários em que há maior concentração de corridas e sobre os motivos das solicitações de corridas estão em sintonia com outras características dos usuários do Moto Táxi. Segundo mais da metade dos entrevistados (58\%) a maioria dos usuários são adultos jovens de baixa renda, principalmente empregados e estudantes que tem horários rígidos. Não há preponderância de homens ou de mulheres entre os usuários, "todos têm pressa" como afirmou um mototaxista da Vitória central da zona leste da cidade.

Não é apenas a distância em relação ao Centro Principal que permite aos mototaxistas encontrar pessoas dispostas a se valer de seus serviços. O modo como funcionam as linhas de ônibus favorece a procura por esse tipo de transporte

Como ocorre em outras grandes cidades deslocar-se entre os bairros pode exigir do cidadão tomar duas ou três conduções, o que além de ser mais caro pode ser muito demorado. Em Londrina, o sistema de terminais urbanos situados nos bairros a partir dos quais se pode tomar outra condução sem pagar nova passagem minimiza, apenas em parte, as dificuldades de circular entre áreas periféricas.

Para uma pessoa que se desloca diariamente entre dois bairros da cidade há poucas opções. Para uma empregada doméstica que, 
por exemplo, tenha de ir da zona norte à zona oeste da cidade as linhas de ônibus diretas, isto é, que não passem pelo Terminal Central, são praticamente inexistentes ${ }^{163}$. Em geral é preciso tomar uma condução na zona norte, desembarcar no Terminal Central e esperar por outro ônibus para chegar aos bairros da zona oeste. Esse trajeto pode levar mais de uma hora e meia, conforme o momento do dia.

\section{Mapa 17 \\ Londrina: distância relativa das Centrais de Moto Táxi ao Centro Principal, 2008.}

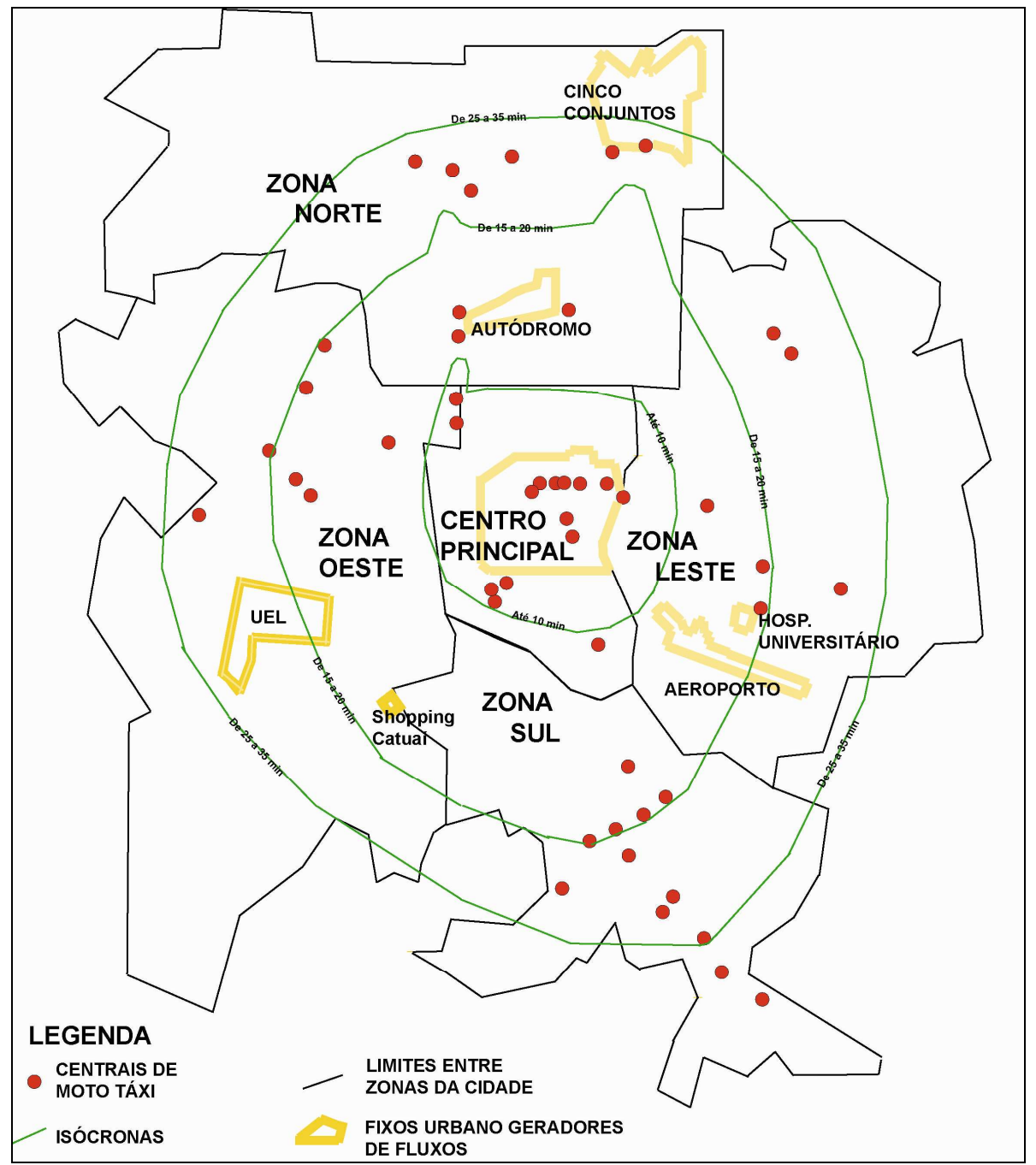

Fonte: Trabalho de campo, 2008

\footnotetext{
${ }^{163}$ No caso especifico do trajeto entre a zona norte, área de concentração da população pobre de Londrina, e a zona oeste, onde estão aos condomínios fechados, há apenas uma linha direta que vai até o Shopping Catuaí, mas essa linha, além de apenas se aproximar da área onde estão os condomínios, tem horários muito restritos de circulação.
} 
Os mototaxistas realizam a maior parte de suas viagens para o Centro Principal. Contudo, também foi citada pelos entrevistados como solicitação freqüente da parte dos passageiros a necessidade de circular entre os bairros e em direção a outros fixos geradores de fluxos situados fora da área central como: as universidades, o hospital universitário, o subcentro da Avenida Saul Elkind na zona norte e o Shopping Catuaí.

Se o transporte de passageiros predomina em termos quantitativos, as solicitações de pequenas empresas, escritórios e indivíduos para transportar encomendas, documentos ou realizar serviços diversos também são fundamentais para a sobrevivência na atividade, pois este último tipo de corrida remunera melhor os mototaxistas do que o primeiro.

Dentre os 74 mototaxistas de todas as partes da cidade que responderam ao questionário, 31, ou seja, $42 \%$ do total disseram que o transporte de encomendas (documentos e objetos) responde por no mínimo a metade de suas corridas diárias ${ }^{164}$. Dentre esses 31 mototaxistas, nada menos do que 64\% dos entrevistados, tinham mais de 5 anos na profissão. Quanto mais tempo na profissão maior a participação de tarefas ligadas ao transporte de encomendas, documentos e a realização de serviços bancários para empresas e indivíduos no cotidiano do mototaxista.

Essa característica da atividade pode ser complementada pela indicação dada pelos mototaxistas em relação à importância que a confiança e o conhecimento pessoal tem para a conquista de clientes regulares, tanto entre as empresas, como entre os passageiros. Essa confiança segundo os entrevistados tem inicio na observação, nos contatos face a face propiciados pela vizinhança. A grande maioria das centrais visitadas está situada nas áreas de concentração de padarias, lojas, mercadinhos, farmácias, postos de gasolina, entre outros tipos de

\footnotetext{
${ }^{164}$ Para 11 mototaxistas, o que corresponde a $15 \%$ dos que responderam ao questionário, as corridas para transporte de encomendas correspondem a mais de $70 \%$ de suas viagens diárias. O tempo de atuação como mototaxista desses profissionais variou entre 2 e 10 anos.
} 
comércio e serviços situados nos bairros. A proximidade com essa gama de atividades permite que, aos poucos, se construa uma relação de confiança nos serviços de determinado profissional e/ou da Central. Segundo a proprietária da Central JR, situada na zona leste da cidade:

A confiança na Central vem porque a pessoa pode ver se a Central é organizada, se não há bagunça, se alguém sai no jornal com alguma notícia meio complicada, e tudo mais. A pessoa pede um serviço simples, entregar uma encomenda, por exemplo, e vê se tudo sai direitinho. Daí ela vai pedindo geralmente o mesmo mototaxista e aos poucos vai pedindo serviços de banco ou outras tarefas que exigem mais confiança.

A complementaridade entre o serviço de Moto Taxi e pequenas empresas urbanas é um aspecto fundamental da existência e do funcionamento dessa atividade. Essa complementaridade reflete a maneira pela qual esses trabalhadores participam da divisão social do trabalho, estabelecendo formas de cooperação entre atividades econômicas distintas e separadas pela fragmentação a que já se referia Roberto Lobato Correa (1995) e que caracteriza o meio urbano.

As dificuldades de acesso ao Centro Principal a que estão submetidas as pequenas empresas distribuídas pelos bairros da cidade ou a possibilidade de que pequenas e médias empresas situadas na área central possam reduzir o tempo gasto em deslocamentos a outros municípios, a indústrias ou a residência de consumidores ${ }^{165}$ localizadas nas periferias, indicam o modo como esses atores da economia urbana são afetados pelas chamadas "deseconomias de aglomeração". Esse termo neoclásssico expressa as dificuldades, sobretudo as de circulação inerentes ao meio construído nas cidades. Essas dificuldades se ampliam com o aumento progressivo da extensão da cidade e da distancia relativa criada pelo tempo exigido pela circulação interna.

A produção social do meio urbano se faz, cada vez mais, de forma intencional e voltada para as necessidades dos capitais hegemônicos, redefinindo assim o valor de uso dos diversos lugares

\footnotetext{
${ }^{165}$ Em Londrina as periferias urbanas são compostas também por condomínios fechados dos mais variados tipos e tamanhos, localizados a distancias relativamente grandes do Centro principal, assim como por concentrações industriais (CILOS).
} 
internos à cidade ${ }^{166}$. Contudo, esse processo contínuo de modernização do meio construído não alimenta apenas o Circuito Superior.

A alteração no valor específico das diversas frações do espaço tem um impacto sobre a economia moderna, aumentando a concorrência e a distância entre firmas, mas também influi sobre o resto da sociedade e economia, pelo fato de que aquilo que se tornou deseconomia urbana para uns é a própria economia para outros. Isso é evidente nas grandes cidades. São as chamadas deseconomias que viabilizam a chegada e a permanência dos pobres e de atividades pobres nas grandes cidades. (SANTOS, 1994, p. 136)

No entanto é preciso deixar claro que para Milton Santos essas conseqüências não consideradas pelas ideologias travestidas de teorias, que são subjacentes a muitas práticas do planejamento urbano. Os termos neoclássicos "economias externas e deseconomias de aglomeração", em geral, funcionam como argumentos de determinadas "teorias de planejamento" para as quais o capital social geral que é a cidade, deve ser posto a serviço de grandes corporações globalizadas.

A teoria subjacente a este planejamento é toda ela, ou quase toda muito mais uma ideologia que uma teoria. De teoria tem apenas a forma, não é baseada na realidade vivida, e o resultado de sua aplicação é o oposto de suas promessas. Sendo ideologia, porém, é responsável construção de novos espaços e pela formulação do espaço urbano atual.[...]

Uma grande firma que se localiza numa grande cidade servida por instalações que facilitam o seu trabalho está fadada a um lucro muito maior do que a que se dirige a uma outra cidade que não dispõem de equipamentos. E, na mesma cidade, as possibilidades de lucro - de realizar mais valia - são diferentes em função das diferenças de uso da cidade pelas diferentes firmas. Pela sua localização, certas empresas fazem circular rapidamente sua produção, mas outras há que não podem, sequer mudar de lugar e se sujeita, por exemplo, aos engarrafamentos e outras restrições de uso, vendo reduzida a sua fluidez, indispensável num mundo em que a economia é sobretudo uma economia de fluxos.(SANTOS, 1994, p. 138, 139)

Como indica o trecho citado as economias externas e as deseconomias não afetam da mesma maneira os diferentes capitais e as diferentes formas de trabalho presentes na cidade. A socialização

\footnotetext{
${ }^{166}$ No caso de Londrina é possível fazer referencia tanto as áreas destinadas à implantação industrial e atração de indústrias como ao parque tecnológico destinado a reunir serviços modernos de tecnologia de informação ou mesmo as áreas supervalorizadas em que a Prefeitura tem permitido uma intensa verticalização como a Gleba Palhano e a área de concentração dos condomínios fechados, ambas situadas na direção sudoeste em relação ao Centro Principal.
} 
contraditória da cidade, como capital geral, usado seletivamente e privatisticamente aprofunda as contradições e, a partir de ideologias que elegem como valores supremos a modernização e competitividade, procura deslocá-las, mas não é capaz de reduzir as tensões que emanam das necessidades de sobrevivência daqueles que foram tornados excedentes pela dinâmica da reestruturação socioespacial.

Em Londrina verificamos que há uma grande variedade de pequenas empresas que solicitam diariamente 0 atendimento dos mototaxistas.

Tabela 12

Tipos de empresas que solicitam o serviço de Moto Táxi, 2008.

\begin{tabular}{|c|c|c|c|}
\hline N. $\mathbf{0}$ & $\begin{array}{l}\text { Tipos de empresas atendidas } \\
\text { pelas centrais }\end{array}$ & $\begin{array}{l}\text { N.o de centrais } \\
\text { que citou o tipo } \\
\text { de empresa }\end{array}$ & $\begin{array}{l}\text { Percentual de centrais que } \\
\text { citaram o tipo de empresa } \\
\text { em relação ao total de } \\
\text { centrais entrevistadas* } \\
(\%) \\
(\%)\end{array}$ \\
\hline 1 & $\begin{array}{l}\text { Lojas de autopeças - para } \\
\text { caminhões e automóveis }\end{array}$ & 16 & 45 \\
\hline 2 & Comércio varejista (diversos) & 10 & 29 \\
\hline 3 & $\begin{array}{l}\text { Farmácias (que não pertencem } \\
\text { a grandes redes e se localizam } \\
\text { nos bairros) }\end{array}$ & 9 & 26 \\
\hline 4 & $\begin{array}{l}\text { Restaurantes (entrega de } \\
\text { refeições em marmitas) }\end{array}$ & 9 & 26 \\
\hline 5 & Padarias & 8 & 23 \\
\hline 6 & $\begin{array}{l}\text { Depósitos de material para } \\
\text { construção }\end{array}$ & 8 & 23 \\
\hline 7 & Floriculturas & 8 & 23 \\
\hline 8 & Oficinas de conserto de carros & 6 & 17 \\
\hline 9 & Pequenos mercados & 6 & 17 \\
\hline 10 & Casas de ração e pet shop & 6 & 17 \\
\hline 11 & Escritórios de contabilidade & 5 & 14 \\
\hline 12 & Escritórios de advocacia & 5 & 14 \\
\hline 13 & Açougues & 5 & 14 \\
\hline 14 & $\begin{array}{l}\text { Oficinas de reparação e } \\
\text { assistência técnica }\end{array}$ & 5 & 14 \\
\hline 15 & Despachantes & 5 & 14 \\
\hline 16 & $\begin{array}{l}\text { Consultórios e clinicas } \\
\text { odontológicas }\end{array}$ & 5 & 14 \\
\hline 17 & Lojas de material elétrico & 4 & 11 \\
\hline 18 & $\begin{array}{l}\text { Lojas de peças para } \\
\text { motocicletas }\end{array}$ & 4 & 11 \\
\hline
\end{tabular}

Fonte: Trabalho de Campo, 2007.

Observação*: Foram entrevistadas 35 Centrais 
A lista de empresas que solicita o serviço dos mototaxistas inclui 18 tipos diferentes, citados por pelo menos $10 \%$ das centrais entrevistadas. Entre os cinco tipos de empresas que mais utilizam os serviços do moto táxi estão: lojas de autopeças, oficinas de conserto de automóveis, restaurantes que fornecem marmitas, lojas de comércio varejista em geral e farmácias que não pertencem a grandes redes.

Londrina reúne diversos estabelecimentos ligados à comercialização de autopeças; mercadorias que se configuram importantes não apenas para o consumo final, mas também para o consumo produtivo. A distribuição de peças para conserto de veículos automotores reflete a inserção de toda região na divisão do trabalho.

A intensa mecanização das atividades agrícolas, o escoamento das safras e a própria urbanização requerem a presença e o funcionamento de uma variada gama de veículos: carros, motos, caminhões, colheitadeiras, tratores, etc.

O fato de que as lojas de autopeças, tanto grandes estabelecimentos pertencentes ao circuito superior, como outros menores, estejam entre as empresas que mais solicitam os serviços do Moto Táxi merece algum destaque. Esse dado evidencia a complementaridade e a dependência das atividades do circuito inferior em relação ao circuito superior e, conseqüentemente, em relação à divisão hegemônica do trabalho.

No contexto intraurbano o conjunto dos mototaxistas consome cotidianamente produtos e serviços diversos, gastando uma parte considerável de seus ganhos para manter a atividade. O gasto mínimo informado na pesquisa foi de $R \$ 450,00$ e o maior foi de $R \$$ $1.000,00$.

As variações estão ligadas à jornada, ao número de corridas realizadas no período, ao tipo de clientes regulares que o mototaxista atende (passageiros ou serviços diversos a empresas ou particulares como entregas, serviços bancários, viagens, etc.). Os itens que compõem essa 
despesa representam gastos que se diferenciam quanto à periodicidade. As despesas diárias são o combustível, refeições e diária paga à central. Ao longo do mês há a troca de óleo e, em períodos um pouco maiores, de dois a três meses, a troca de pneus e da "relação" que é a corrente que transmite movimento e força do motor às rodas da moto. Em períodos ainda maiores há outros itens de manutenção e a troca da própria motocicleta.

Com base nos dados da pesquisa e considerando apenas as despesas realizadas com uma freqüência mínima de até três meses, calculamos que, no início do ano de 2008, o gasto médio mensal de cada trabalhador para manter sua atividade girava em torno de $\mathrm{R} \$ 650,00$. Se multiplicarmos esse gasto médio mensal pelo número estimado de 1.000 mototaxistas, chegamos a um resultado interessante: $\mathrm{R} \$ 650.000,00$ por mês são injetados na economia de Londrina a partir do consumo desses trabalhadores. Portanto, é possível estimar que, levando em conta apenas os gastos dos mototaxistas, a atividade seja responsável pela circulação mensal de mais de meio milhão de Reais na cidade. A esse montante podem ser acrescidos os gastos das Centrais com aluguel, telefone, funcionários, equipamento e serviço de rádio, elevando ainda mais essas cifras.

Olhar o serviço de Moto Taxi dessa perspectiva implica perceber que a economia urbana não se resume às atividades modernas. As atividades do circuito inferior em conjunto são geradoras de fluxos econômicos consideráveis e que, no contexto da urbanização brasileira, a concentração de pessoas pobres nas cidades é, como preconiza a teoria dos circuitos (SANTOS, 1979), um fator fundamental a considerar no entendimento do processo de urbanização e também da cidade. Assim é possível evitar o reducionismo de abordagens parciais que priorizam apenas o que é hegemônico e as zonas luminosas do urbano. 


\subsection{3 - Motoboys e entregas urbanas: complementaridade e fluxos intraurbanos}

A gama de empresas nas quais os chamados motoboys prestam seus serviços é menos variada do que aquelas que são atendidas pelos mototaxistas. Em geral o trabalho dos motoboys está ligado à circulação de mercadorias de pequeno porte, informações e documentos pela cidade e também entre Londrina e cidades vizinhas.

Considerando apenas os motoboys que trabalham para as empresas de entregas urbanas que entrevistamos, a presença desses trabalhadores é mais freqüente nos seguintes tipos de empresas ${ }^{167}$ : farmácias de grandes redes (32\%), restaurantes e lanchonetes (24\%), lojas de autopeças (19\%), bancos (10\%), loja de tintas e cartórios (4\%). Quanto aos motoboys que trabalhavam como autônomos ou eram empregados de empresas de entregas menores as empresas mais mencionadas foram: pizzarias, lanchonetes, distribuidoras de água, lojas de autopeças e distribuidoras de suprimentos de informática (cartuchos de tinta para impressoras).

Esse dado reafirma a hipótese de que a existência dos circuitos da economia urbana corresponde à segmentação do mercado dada pela convivência em mesmo meio urbano de capitais de diferentes expressões e com diferentes demandas por serviços e outras formas de cooperação. Esses diferentes mercados entrelaçados pela cidade reafirmam a premissa de que a análise da economia urbana requer uma abordagem que deve evitar as parcialidades e deve, sobretudo, evitar confundir a economia urbana com o circuito superior.

Considerando a diversidade de situações que envolvem os entregadores, cabe ressaltar que nosso foco se colocou sobre os motoboys

\footnotetext{
${ }^{167}$ A lista dos clientes atendidos pelos motoboys da Vai-Vem, Sol e Terceiriza contempla ainda os seguintes tipos de empresas: Agência de Publicidade, Canal Polishoping, Financeiras, Loja de Cosméticos, Locadora de Vídeo, Dentista, Laboratório de Análises Clínicas, Hospitais, Hotéis, Loteadora e Empresa de Recolocação de Mão de Obra.
} 
empregados por empresas de entrega urbana que prestam serviços a terceiros que totalizaram 32 trabalhadores, os quais representam $61 \%$ do total de entrevistados (52 pessoas).

O moto frete nesse caso não se caracteriza pela cobrança direta do serviço de transporte, e sim pela intermediação da contratação de mão de obra que presta um serviço de transporte específico: as entregas. Os contratos celebrados entre as empresas de entrega e seus clientes são pautados pelo número de entregadores a ser disponibilizado e na distância que, de forma simplificada, leva em conta apenas a questão das entregas serem feitas em Londrina ou em outros municípios.

Segundo as entrevistas realizadas com os proprietários das empresas Vai e Vem, Sol e Terceiriza, dentre seus clientes predominam empresas de grande e médio porte, com destaque para as redes de farmácias e algumas multinacionais ${ }^{168}$. A participação das pequenas e microempresas varia entre 20 e 30\% do total das três maiores empresas de entrega. A quase totalidade das empresas atendidas está situada em Londrina e a maior parte na área central da cidade. A exceção fica por conta da empresa Sol Motoboys que abriu uma pequena filial em Maringá e atende também empresas daquela cidade.

As mercadorias mais freqüentemente transportadas pelos 52 motoboys que responderam ao questionário são: alimentos, remédios e autopeças presentes nas respostas de $61 \%$ dos entrevistados. A maioria das entregas contratadas se realiza dentro da cidade. O número de viagens diárias varia bastante conforme a empresa atendida pelo motoboy:

Quando estou na "empresa" várias firmas ligam. Escolhem um motoqueiro e pedem para fazer as entregas. Desse jeito eu faço umas 15 entregas por dia. Na farmácia [...] dá mais, faço umas 30 entregas. Levo troco quando necessário ou máquina de passar o cartão quando faço entrega para empresa de produtos de beleza. (C.R. motoboy da empresa Sol)

\footnotetext{
${ }^{168}$ Farmácias com diversas lojas na área central da cidade como as Redes Nissei, Vale Verde, Drogamais e Senador; as multinacionais Sandoz, Dixie Toga, Pellegrino que pertence ao Grupo Affinia uma multinacional do setor de auto peças criada em 2004 a quem pertencem marcas conhecidas como a Brosol de carburadores e a Nakata de amortecedores e ainda as grandes empresas de comércio eletrônico como a "Americanas.com" e a Submarino.
} 
Por meio dos questionários respondidos pelos motoboys verificamos que $83 \%$ dos entrevistados ( 43 pessoas de um total de 52 entrevistados) realizam entregas em outros municípios, porém, dentre eles, apenas $19 \%$ ( 8 motoboys) disseram que fazem essas entregas com freqüência diária.

Tabela 13

Motoboys que realizam entregas em outros municípios, 2008.

\begin{tabular}{|c|c|c|}
\hline Freqüência das Entregas & $\begin{array}{c}\text { N.o de } \\
\text { Motoboys }\end{array}$ & $\mathbf{\%}$ \\
\hline $\begin{array}{c}\text { Motoboys que realizam entregas } \\
\text { em outros municípios }\end{array}$ & 43 & 100 \\
\hline $\begin{array}{c}\text { Pelo menos uma vez por dia } \\
\text { (Diariamente) }\end{array}$ & 8 & 19 \\
\hline $\begin{array}{c}\text { De uma a três vezes por semana } \\
\text { (Semanalmente) }\end{array}$ & 17 & 39 \\
\hline $\begin{array}{c}\text { De uma a três vezes por mês } \\
\text { (Mensalmente) }\end{array}$ & 18 & 42 \\
\hline
\end{tabular}

Fonte: Trabalho de campo, 2008

A freqüência das entregas em outros municípios é relativamente baixa no caso dos motoboys. A grande maioria ( $81 \%$ ) faz essas viagens semanalmente ou apenas algumas vezes no mês.

As entregas em outros municípios se concentram em Cambe e Ibiporã, citados por todos os 43 motoboys que realizam entregas em outros municípios. Os outros municípios citados por pelo menos quatro motoboys entrevistados estão relacionados na tabela a seguir.

Tabela 14

Municípios que recebem entregas por motoboys de Londrina, 2008

\begin{tabular}{|c|c|c|}
\hline Muncípios & $\begin{array}{c}\text { N.o de motoboys que } \\
\text { faz entregas no } \\
\text { muncipio (pessoas) }\end{array}$ & $\begin{array}{c}\text { Percentual de Motoboys } \\
\text { que realiza entregas no } \\
\text { Municipio (\%) }\end{array}$ \\
\hline Cambé & 43 & 100 \\
\hline Ibiporã & 40 & 93 \\
\hline Rolândia & 14 & 33 \\
\hline Arapongas & 5 & 12 \\
\hline Maringá & 5 & 12 \\
\hline Apucarana & 4 & 9 \\
\hline
\end{tabular}

Fonte: Trabalho de Campo 2008

As despesas diretamente ligadas ao trabalho dos motoboys são cobertas pelas empresas às quais esses trabalhadores prestam seus 
serviços ou de que são empregados ${ }^{169}$. São gastos como o consumo de combustível, refeições e parte das peças e serviços necessários à manutenção da moto. Na média, as despesas mensais com combustível giram em torno de $\mathrm{R} \$ 220,00$ por motoboy. Na média as despesas mensais com manutenção envolvendo itens como: óleo, freios, relação (corrente da moto) e pneus que se desgastam rapidamente e proporcionalmente à intensidade do uso da moto giram em torno de $\mathrm{R} \$$ 170,00 por motoboy ${ }^{170}$.

As três maiores empresas de entregas urbanas mantêm convênios e acordos com lojas de peças para motos, postos de gasolina e oficinas mecânicas que priorizam o atendimento dos motoboys, evitando a interrupção do serviço prestado aos clientes que contratam seus serviços.

Outras despesas correm por conta e risco do motoboy. São despesas para compra de itens de segurança como o capacete, roupas especiais e capas para dias de chuva etc.

Mas a principal despesa que pesa sobre os motoboys é a que permite a aquisição da motocicleta com potência de no mínimo 125 cilindradas, condição essencial para o exercício da atividade. Verificamos que $87 \%$ dos motoboys entrevistados eram proprietários da moto usada no trabalho.

Tabela 15

Propriedade da motocicleta utilizada nas entregas urbanas, 2008.

\begin{tabular}{|c|c|c|}
\hline Propriedade da moto & $\begin{array}{c}\text { N.o de } \\
\text { motoboys }\end{array}$ & $\%$ \\
\hline Moto de propriedade do motoboy & 45 & 87 \\
\hline Moto de propriedade da empresa & 7 & 13 \\
\hline Total & 52 & 100 \\
\hline
\end{tabular}

Fonte: Trabalho de Campo, 2008

\footnotetext{
${ }^{169}$ Vale lembrar que, como vimos no capítulo 3, entre os 52 entrevistados havia 25 motoboys, ou seja, $48 \%$ do total, que trabalhavam exclusivamente para as três maiores empresas de entregas urbanas de Londrina. Outros 22 motoboys trabalhavam simultaneamente, no período noturno ou em finais de semana, em outras atividades e outros locais como farmácias e pizzarias. Por fim, 5 entrevistados trabalhavam diretamente para lojas de tinta, autopeças e pizzaria e também outras empresas de entregas urbanas.

170 Levando em conta os valores médios por motoboy e o número total de motoboys, estimamos que a soma dos gastos mensais das três maiores empresas de entregas urbanas de Londrina (Terceiriza, Sol e Vai-Vem) giram em torno de $\mathrm{R} \$ 35.000,00$ com combustível e R \$27.000,00 com manutenção.
} 
Do conjunto de trabalhadores que usavam a moto própria no trabalho, mais da metade, 58\% (26 motoboys), pagavam financiamento. A possibilidade de conseguir um financiamento é, portanto, uma questão de sobrevivência para esses trabalhadores, que se vêem subordinados aos juros altos exigidos em financiamentos de prazo mais dilatado ${ }^{171}$.

Tabela 16

Valor da prestação dos financiamentos, 2008.

\begin{tabular}{|c|c|c|}
\hline $\begin{array}{c}\text { Valor das Prestações } \\
\text { (Reais de 2008) }\end{array}$ & $\begin{array}{c}\text { N..- de } \\
\text { Motoboys } \\
\text { (Pessoas) }\end{array}$ & $\%$ \\
\hline $\mathbf{R} \$ \mathbf{1 4 0 , 0 0}$ a 199,00 & 4 & 15 \\
\hline $\mathbf{R} \mathbf{2 0 0 , 0 0}$ a 250,00 & 14 & 54 \\
\hline $\mathbf{R} \$ \mathbf{2 5 1 , 0 0}$ a 320,00 & 8 & 31 \\
\hline Total & $\mathbf{2 6}$ & $\mathbf{1 0 0}$ \\
\hline
\end{tabular}

Fonte: Trabalho de Campo, 2008

Considerando o piso salarial dos entregadores que é de $\mathrm{R} \$ 544,00^{172}$ fica evidente a dificuldade desses trabalhadores para arcar com as prestações do financiamento da moto. As prestações, cujo valor médio é de $R \$ 233,40$, consomem parte significativa das rendas desses trabalhadores, fato que ajuda a compreender a extensão de suas jornadas de trabalho, que gira em torno de 12 horas diárias, seis dias por semana, assim como a necessidade de trabalhar em dois ou mais locais ou de constantemente fazer horas extras.

As revendedoras de motos e as financeiras que concedem o crédito necessário à compra desse bem beneficiam-se amplamente da demanda gerada por motoboys e mototaxistas e podem ser consideradas fundamentais para a atividade como um todo.

\footnotetext{
${ }^{171}$ A maioria das motos foi financiada em 24 prestações.

172 O valor de R\$544,00 está definido na clausula $5^{\text {a }}$ da Convenção Coletiva do Trabalho 200/2009 pactuada entre o Sindicato das Empresas de Assessoramento, Perícias, Informações, Pesquisas e Serviços Contábeis de Londrina (SESCAP) e o Sindicato dos Empregados em Empresas de Contabilidade, Assessoramento, Perícias, Informações, Pesquisas e Empresas Prestadoras de Serviços de Londrina e região (SINDASPEL).
} 


\section{3 - As escalas da ação no circuito inferior}

Com diferentes intensidades as três atividades do circuito inferior ampliam a vida de relações de Londrina com seu entorno regional

Com exceção do serviço de entregas urbanas em que a as viagens para outros municípios são reduzidas, as outras duas atividades são marcadas pelas constantes relações com pessoas, empresas e instituições situadas em outros municípios

Os motivos das viagens são os mais variados no caso do Moto Táxi. No caso do Camelódromo o motivo principal é o preço das mercadorias e as facilidades de pagamento.

As ações no caso do Camelódromo envolvem escalas mais amplas, são extensões maiores. É próprio do comércio colocar em contato áreas distantes, fazer circular as mercadorias para explorar as diferenças de preço, o lucro mercantil.

O Moto Táxi estabelece ligações diárias com Cambe e Ibiporã, o fluxo total, considerada todas as Centrais é significativo. As viagens para o entorno caracterizam a escala de ação dessa atividade.

As entregas urbanas se restringem a Cambe e Ibiporã, mas mesmo assim não chegam a ser diárias como no Moto Táxi.

Londrina exerce uma forte polarização sobre seu entorno regional. Em geral, a polarização de uma cidade sobre as outras que the são próximas é atribuída às atividades do circuito superior, especialmente os serviços, medidos por seu grau de raridade.

Considerando as escalas da ação que a analise das três atividades revela é possível propor que, no período atual, o circuito inferior também participa dos múltiplos fluxos que estabelecem a polarização de uma cidade média. 


\subsection{1 - O Camelódromo e a articulação de diferentes escalas}

Situado em local estratégico, próximo ao calçadão de Londrina, o Camelódromo, forma especifica de concentração e funcionamento do comércio popular, tem uma abrangência espacial na qual a escala local tem papel preponderante, entretanto, outras escalas estão presentes tanto no que se refere aos locais em que são adquiridas as mercadorias como às vendas considerando os locais de origem dos compradores.

Dentre os 41 estabelecimentos que não realizavam suas compras em Londrina, São Paulo foi citado por $61 \%$ dos entrevistados como o principal local de origem dos produtos, seguido do Paraguai indicado por $29 \%$. Os outros $10 \%$ correspondem a Maringá, Cianorte e Apucarana no Paraná além de São José do Rio Preto, Blumenau e Rio de Janeiro.

Dos 81 entrevistados, 39 citaram São Paulo como origem de parte ou de toda mercadoria vendida no estabelecimento, o que corresponde a $48 \%$ dos estabelecimentos. O Paraguai foi citado por 18 estabelecimentos como local de origem das mercadorias, ou seja, 22,2\% dos entrevistados. Portanto, atualmente, o Paraguai (Ciudad del Este e Guaira) deixou de ser o principal fornecedor das mercadorias vendidas no Camelódromo e a cidade de São Paulo, assumiu esse papel, sobretudo a região do Brás e Pari, Rua Vinte e Cinco de Março, Rua Santa Ifigênia entre outras

A origem dos produtos indica que, pelo lado da aquisição das mercadorias, o Camelódromo de Londrina articula diferentes circuitos espaciais de produção e circulação que vão da escala local à regional e, considerando os fabricantes de grande parte dos produtos comercializados, também à escala internacional.

Algo semelhante, porém com menor abrangência territorial se dá com o lado da venda dos produtos quando consideramos a procedência dos compradores. 
O Camelódromo atende principalmente pessoas de Londrina e municípios vizinhos. Isso reforça suas características como atividade do circuito inferior, em razão de sua forte integração local. As possibilidades de comércio a longa distância e ampliação da área de abrangência de das vendas do Camelódromo por meios eletrônicos não foi constatada durante o trabalho de campo.

Para efetivar as possibilidades abertas pela técnica é preciso estar conectado às redes, especialmente a internet, ser capaz de criar as condições para usar e rentabilizar o empreendimento comercial por meio do comércio eletrônico o que, por vezes demanda a contratação de serviços especializados que auxiliam na manutenção das páginas, sítios e outras estruturas que viabilizam os contatos comerciais. Há aí, portanto, uma seletividade dos atores que podem de fato ser fluídos e usar as redes técnicas de modo a aumentar a competitividade e intensificar um dado modo de usar o território e de convertê-lo em mercado efetivo.

Embora as possibilidades de comércio eletrônico abertas pelas novas tecnologias não estejam totalmente ausentes do Camelódromo a constatação de sua fraca utilização é sustentada até pela reduzida presença de microcomputadores e de acesso a internet nos estabelecimentos.

Em apenas 12 estabelecimentos havia microcomputadores e acesso a internet, ou seja, 15\% dos entrevistados. Quase todos ligados à venda de produtos eletrônicos, computadores, celulares e games. $\mathrm{Na}$ verdade a única exceção foi uma loja de camisetas estampadas especializadas em produzir "camisetas customizadas" com imagens ligadas a bandas de rock $^{173}$.

\footnotetext{
${ }^{173}$ Essa loja mantém página na internet divulgando seus serviços e fornecendo telefone para contato e e-mail. Aceita encomendas de outras cidades e utiliza serviços de moto taxistas e transportadoras para as entregas. Nos outros estabelecimentos a internet e os computadores estavam sendo utilizados para tarefas pontuais ligadas às necessidades próprias de cada loja, como por exemplo; baixar programas para manutenção de computadores (drives para hardwares específicos), demonstrar possibilidades de jogos on-line no caso das lojas de games, acessar site de operadoras no caso das lojas de celular, etc. Em algumas lojas o computador era utilizado como forma de evitar o tédio durante a espera por clientes.
} 
Além de Londrina, os municípios vizinhos completam a área de mercado do Camelódromo. Em apenas 5 estabelecimentos ${ }^{174}$ houve a indicação de que não há, ou são muito poucos os clientes de outros municípios. Desta forma, em 76 questionários, ou seja, para 94\% dos entrevistados, houve a indicação de que o estabelecimento é freqüentado por pessoas de outros municípios.

Os municípios mais próximos a Londrina (Cambé, Ibiporã, Rolândia e Jataizinho) que contam com linhas de ônibus urbanos do sistema metropolitano de transportes foram citados por $84 \%$ dos entrevistados como locais de proveniência dos clientes. Com menos constância aparecem outros municípios para os quais as facilidades de acesso são menores. Assim Apucarana, Arapongas, Assaí e Cornélio Procópio, que dista $70 \mathrm{~km}$ de Londrina, aparecem em 57\% das respostas. A partir daí as menções a cidades mais distantes aparecem pontualmente: Maringá, Campo Mourão, Ourinhos, Curitiba, foram citados em 14\% dos questionários (11 estabelecimentos).

\footnotetext{
${ }^{174}$ Em principio e salvo melhor juízo, não observamos uma relação consistente entre os produtos vendidos (roupas, DVDs e ferramentas) e/ou qualquer outra característica do estabelecimento e a declaração de que não há clientes de outros municípios.
} 
Mapa 18

Fluxos de mercadorias vendidas no Camelódromo de Londrina - 2008

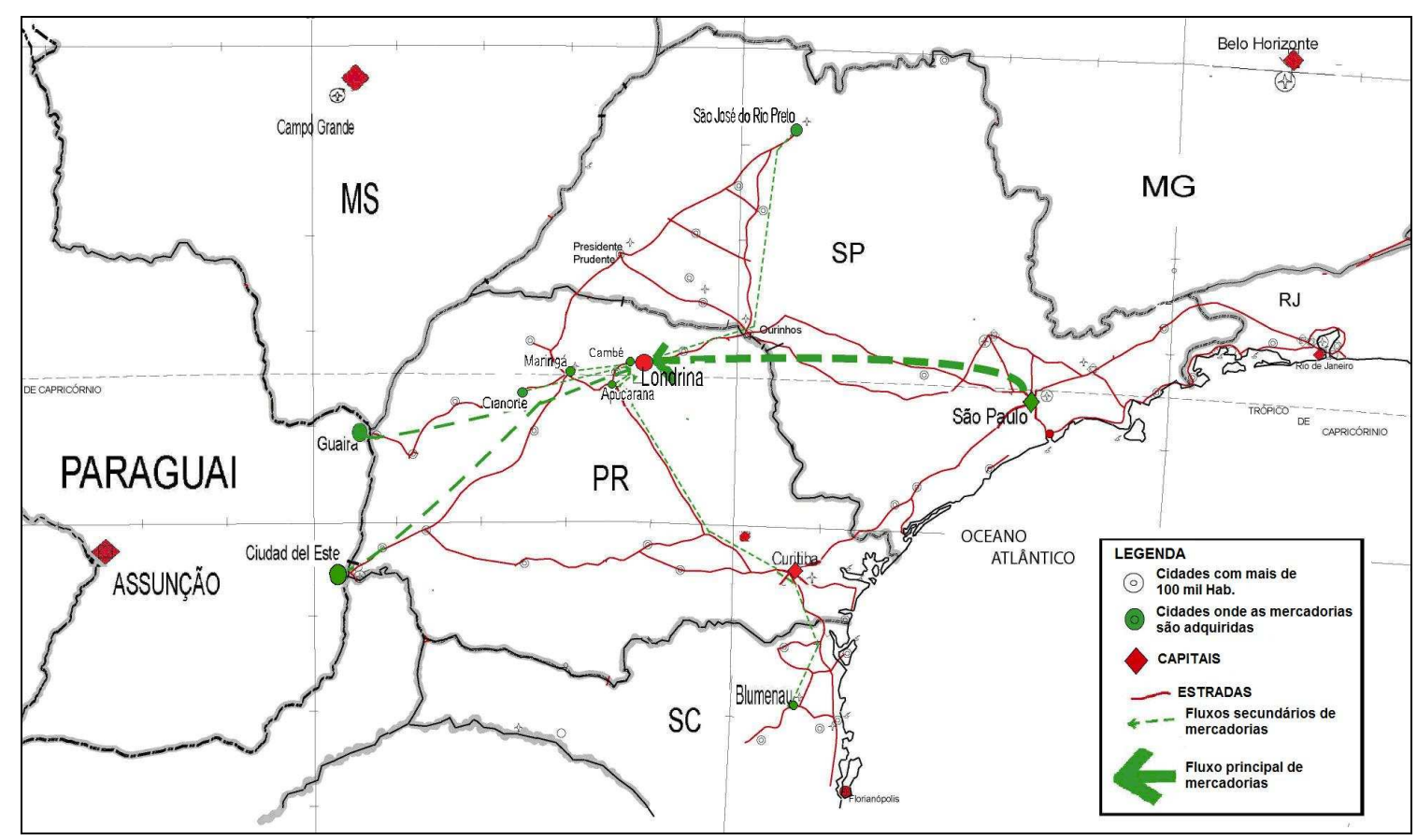

Fonte: Trabalho de campo, 2008 


\section{Mapa 19 \\ Paraná: municípios de procedência dos compradores de mercadorias no Camelódromo de Londrina, 2008 (\%).}

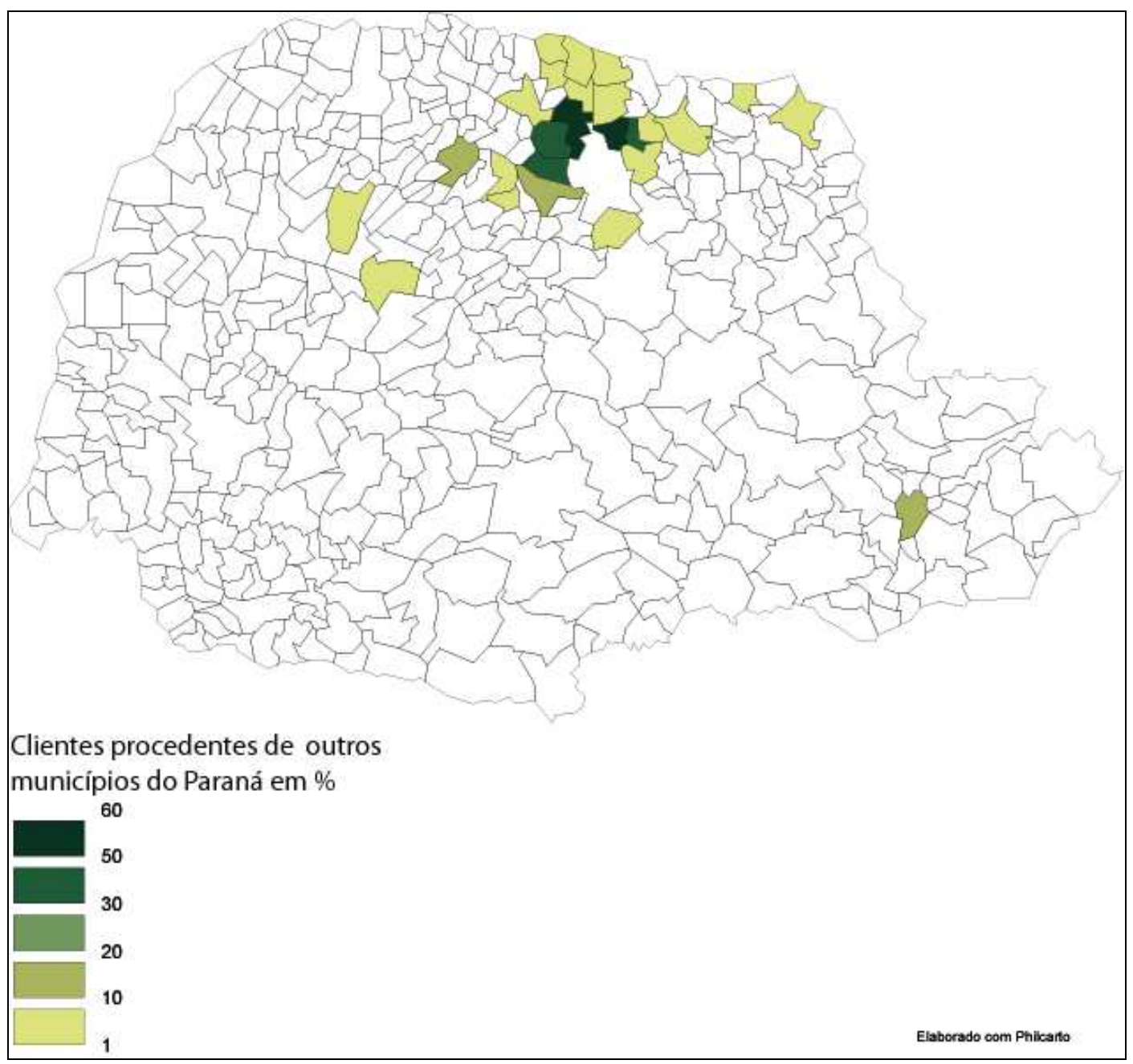

Fonte: Trabalho de Campo, 2008.

Obs: As porcentagens foram calculadas a partir do número de estabelecimentos que indicou ter clientes procedentes de outros municípios, isto é, 76 entrevistados. Desta forma, entre 50 e $60 \%$ dos entrevistados que declaram ter clientes provenientes de outros municípios, indicaram que um dos locais de procedência era, por exemplo, o município de Cambé. 


\subsection{2 - Mototaxistas e motoboys: horizontalidades e verticalidades na circulação de mercadorias no entorno de Londrina}

Os dados e as informações colhidas nos questionários e nas conversas com os trabalhadores do Moto Táxi e das Entregas Urbanas sugerem uma diferença sutil entre as duas atividades no que se refere a algo que thes é comum: a participação na circulação de mercadorias e informações.

A diferença entre o Moto Táxi e as Entregas Urbanas aparece em três pontos básicos. Primeiro na forma como se organizam as relações entre mototaxistas e motoboys e seus contratantes. Segundo na maior variação de tipos de serviços prestados pelos mototaxistas em relação aos motoboys. Por fim, a maior extensão coberta pelas viagens dos primeiros em relação aos segundos.

As entregas realizadas pelos motoboys são predominantemente resultado das vendas, necessidades de comunicação ${ }^{175}$ de empresas do circuito superior. Essa situação na divisão do trabalho imprime características específicas à atividade dos motoboys.

A primeira delas é que o volume das vendas e dos fluxos de informação gerados pelas empresas do circuito superior, associados aos modelos organizacionais adotados pelas mesmas, ensejam a contratação de serviços terceirizados de entrega como estratégia de redução de custos, principalmente trabalhistas, e, simultaneamente como estratégia de competição e de ampliação de sue mercado.

No caso específico da relação entre as empresas de entregas urbanas e as empresas contratantes, especialmente as do circuito superior da economia urbana, a manutenção do serviço de entregas ao longo do tempo é um resultado direto da escala dos fluxos, do grande volume de entregas diárias. Essa relação se baseia em parâmetros definidos quanto ao número de motoboys, a sua distribuição em turnos, a

\footnotetext{
175 Entre as entregas relacionadas às necessidades de comunicação estão: divulgação de eventos, convites, divulgação de produtos e serviços por meio de mala direta, documentos bancários, documentos de cartórios, etc.
} 
obrigatoriedade de substituição dos faltosos, etc. A definição desses parâmetros é objeto central dos contratos celebrados entre empresas do circuito superior e empresas de entregas urbanas, cujos prazos são, em geral, de 24 meses.

Os motoboys como empregados das empresas terceirizadas recebem as determinações de onde e como deveram realizar suas tarefas. Nos locais onde prestam serviço recebem novas instruções sobre a ordem das entregas, os roteiros e outras instruções específicas para cada tipo de entrega, tais como a atenção aos recibos, a necessidade de colher assinaturas, levar troco, etc.

As tarefas realizadas pelos motoboys ligados as empresas de entregas urbanas são definidas por parâmetros contratuais que estabelecem a continuidade e a regularidade do serviço. Os trabalhadores, na condição de empregados assalariados, não participam da definição desses parâmetros, apenas têm de organizar sua atividade por estes. Recebem também instruções específicas dos clientes a quem prestam serviço sobre as entregas que realizam.

Os mototaxistas são trabalhadores autônomos ligados a uma determinada Central. Como autônomos mantêm uma relação direta com seus contratantes, que, em geral, são também muito mais diversificados. Quando um pequeno comerciante, o dono de um açougue ou mercearia do núcleo comercial do bairro em que está instalada a Central de Moto Táxi, solicita o serviço de um mototaxista o valor do serviço e as condições de sua realização são tratadas de imediato pelas duas partes. Mesmo quando um mototaxista presta serviços regulares a uma seguradora ou quando uma dada Central mantém contrato de prestação de serviços com uma grande empresa há uma margem de negociação com o mototaxista em relação às condições e valores do serviço.

A inserção dos mototaxistas na divisão do trabalho decorre de um encontro muito mais fortuito entre necessidades dispersas de 
pequenos comerciantes, pessoas físicas ${ }^{176}$ e empresas. Na imensa maioria dos casos não há contratos formais, apenas acordos verbais. Os mototaxistas têm de obter volume de entregas e serviços necessários à composição de sua renda pela conquista de uma grande quantidade e variedade de clientes. Foram raros os casos em que um mototaxista atende com freqüência diária uma mesma empresa.

As entregas e serviços prestados pelos mototaxistas são muito mais variados, assim como seus contratantes ${ }^{177}$. Não se trata de um processo de terceirização definido por parâmetros contratuais e sim de uma complementaridade e cooperação muito mais aleatória estabelecida entre trabalhadores autônomos, empresas, especialmente as do circuito inferior da economia urbana, e pessoas físicas. Os parâmetros de organização da atividade ficam por conta das Centrais e, principalmente, dos próprios trabalhadores.

Dessa primeira diferença decorre a segunda. Os motoboys, assalariados das empresas de entregas urbanas, realizam corridas que ligam consumidores finais a pontos de venda ou realizam a distribuição de informações entre empresas. Essas corridas se concentram na área central de Londrina e bairros próximos a ela, onde se localiza grande parte do mercado consumidor e de interesse das empresas contratantes.

Os mototaxistas realizam um grande número de corridas entre bairros, distritos rurais e a área central e entre municípios vizinhos e a área central de Londrina. A variedade de locais de destino e de serviços prestados está ligada aos diferentes interesses e necessidades a que esses trabalhadores autônomos atendem.

\footnotetext{
176 Uma situação que chamou minha atenção foi a afirmação de diversos mototaxistas, pelo menos oito profissionais de diferentes locais da cidade, quando perguntados sobre quem são seus clientes, se homens ou mulheres, jovens, idosos, etc. Esses profissionais responderam que muitas mulheres chamam o mototaxista quando precisam ir ao banco receber algum dinheiro (pensão, auxilio do governo, etc.) fazer pagamentos com somas um pouco mais elevadas (prestação da casa, prestação do carro, etc.) ou depositar o resultado das vendas de seus pequenos negócios. A possibilidade de contar com um motaxista conhecido ajuda a evitar assaltos nas saídas de banco ou ser surpreendida durante o trajeto.

${ }^{177}$ A lista dos tipos de empresas citadas por pelo menos $10 \%$ das Centrais visitadas está na tabela 12 na página 248
} 
Há, portanto, um grau de flexibilidade maior nos fluxos efetivados pelos mototaxistas do que naqueles efetivados pela ação dos motoboys. Essa diferença está ligada à forma da relação entre cada um desses trabalhadores e seus contratantes e às características dos contratantes.

\section{Mapa 20 \\ Londrina: representação esquemática dos fluxos principais} e secundários do Moto Táxi, 2008.

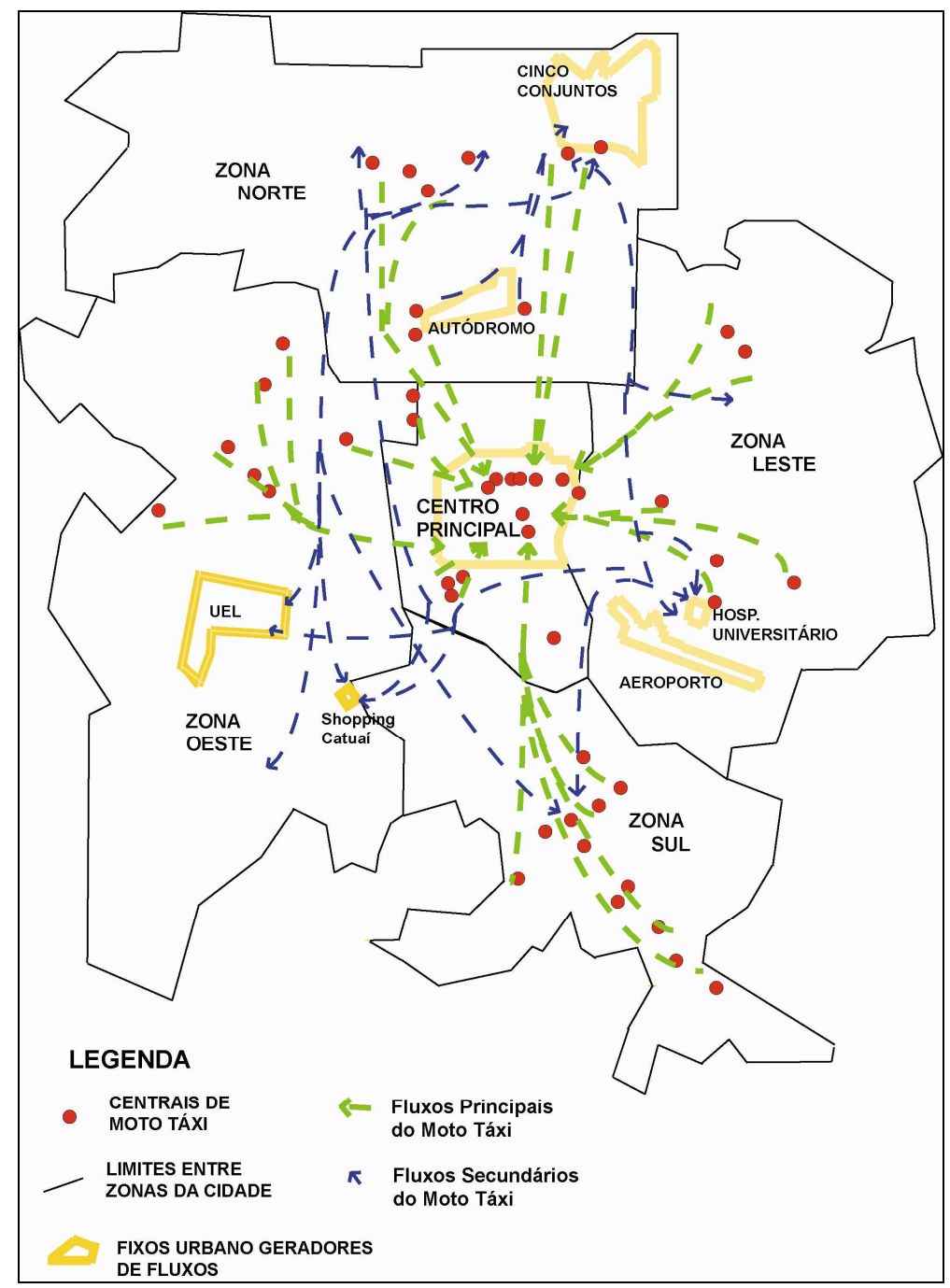

Fonte: Trabalho de campo 
Mapa 21

Londrina: representação esquemática dos fluxos principais das Entregas Urbanas, 2008.

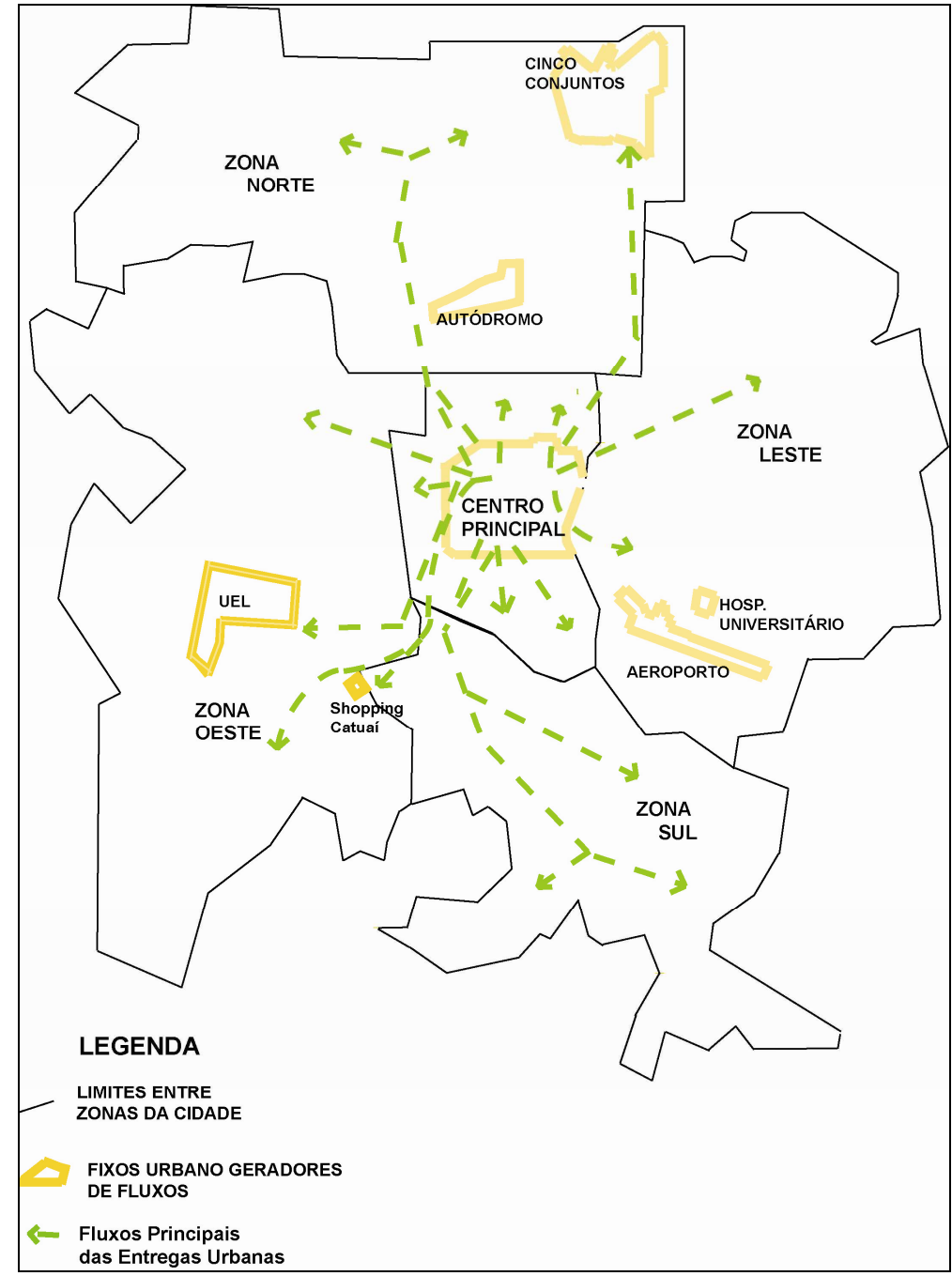

Fonte: Trabalho de campo

Nas relações em que predominam contratantes do circuito superior, sintonizados com as dinâmicas do período atual, aumenta o grau de rigidez que se expressa nos processos de intermediação, no contrato como norma principal, nos requisitos de regularidade e continuidade da atividade.

A forma enviesada de assalariamento que caracteriza o trabalho do motoboy, no qual o principal instrumento de trabalho tem de ser provido pelo trabalhador, como condição da obtenção do emprego se ajusta de forma eficaz às demandas das empresas do circuito superior. 
Esse ajuste fica evidenciado pelo controle que o assalariamento enviesado propicia sobre as ações dos trabalhadores que realizam as entregas urbanas. O volume dos fluxos e o tipo de complementaridade requerida pela terceirização da atividade de Entregas Urbanas autorizam a existência de intermediários: as empresas de entregas urbanas.

Por seu turno, ao exercer a mediação necessária ao processo de terceirização as empresas de entregas urbanas evidenciam uma diferença qualitativa entre os fluxos sob sua responsabilidade. Nesses fluxos articulam-se horizontalidades e verticalidades. Considerando que as verticalidades são "vetores de uma racionalidade superior e do discurso pragmático dos setores hegemônicos, criando um cotidiano obediente e disciplinado" (SANTOS, 2004, p286) e que as horizontalidades são "tanto o lugar da finalidade imposta de fora, de longe e de cima, quanto da contrafinalidade, localmente gerada" (idem) é possível perceber o modo como tal articulação ocorre.

Os fluxos que se efetivam pelo trabalho dos motoboys que trabalham para as empresas de entregas urbanas são parte de um processo de cooperação que aumenta a produtividade e a abrangência territorial de empresas do circuito superior instaladas em Londrina. Nesse processo de cooperação estão presentes e sobrepostas necessidades verticalizadas de redes de farmácias, multinacionais do setor de autopeças, cartórios e outras empresas hegemônicas, que buscam dinamizar a circulação de suas mercadorias e das informações que desejam fazer chegar a clientes e empresas específicas, o que repercute sobre sua competitividade.

Essas necessidades verticalizadas se articulam a horizontalidades que se expressam pela contigüidade entre os pontos de venda dessas empresas e os consumidores individuais e as outras empresas que formam seus mercados. As horizontalidades se expressam também pela necessidade de trabalho dos jovens motoboys e pelos constrangimentos que o meio construído impõe à circulação dessas mercadorias e informações. 
O fato de que os mototaxistas atendem uma diversidade maior de clientes do que os motoboys e de que esses clientes têm diferentes necessidades em relação à circulação, traz implicações sobre a extensão coberta pelos fluxos das duas atividades.

Comparando as viagens realizadas para outros municípios pelos motoboys e mototaxistas verificamos que, no caso dos primeiros, estes realizam um número menor de viagens para outros municípios, contudo, a principal diferença está no número de municípios e na extensão coberta pelos fluxos de cada uma das duas atividades.

\section{Mapa 22}

Norte do Paraná: municípios que recebem corridas dos motoboys pelo menos uma vez por semana, 2008.

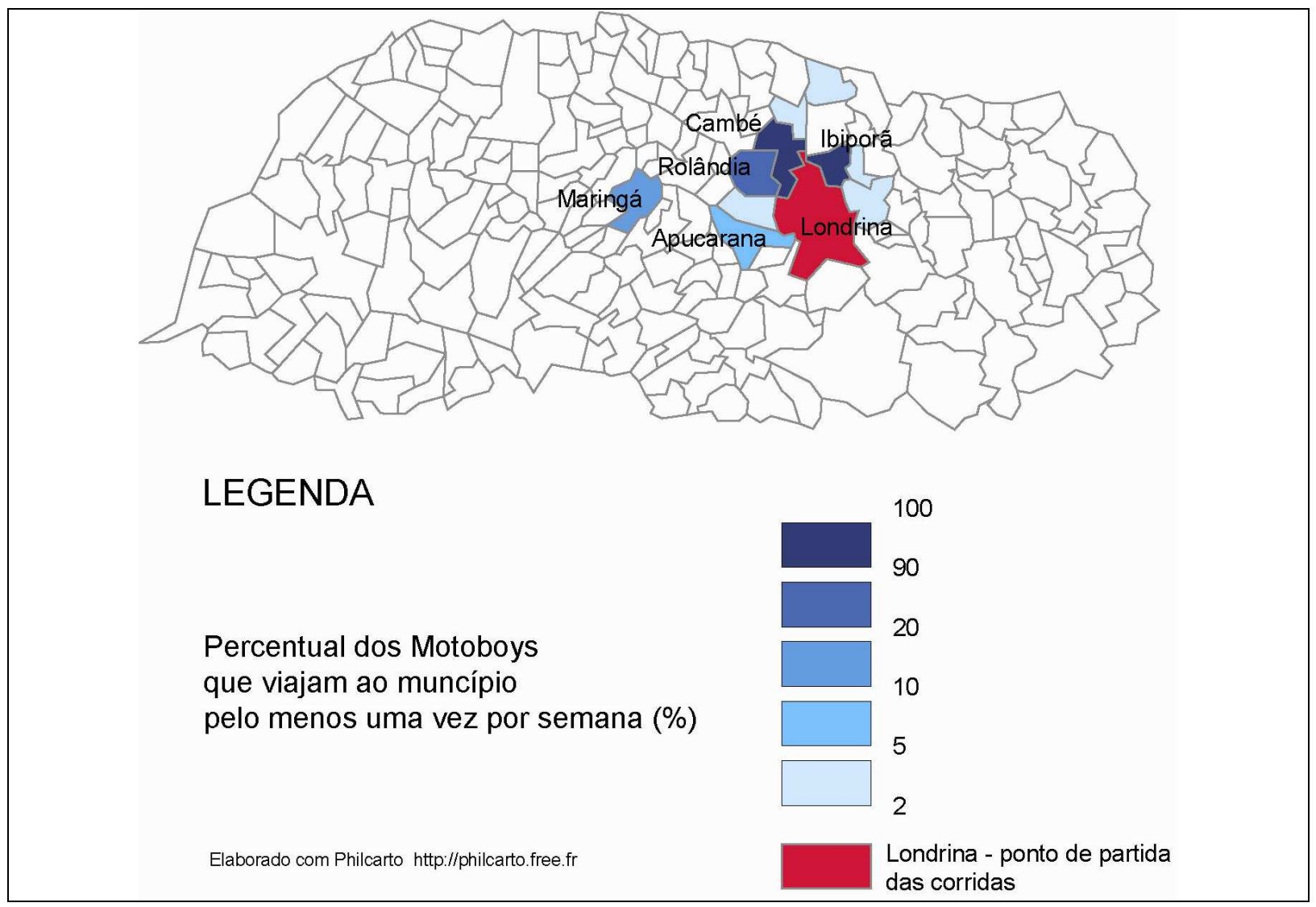

Fonte: Trabalho de campo, 2008 


\section{Mapa 23}

Norte do Paraná: municípios que recebem

corridas dos mototaxistas pelo menos uma vez por semana, 2008.

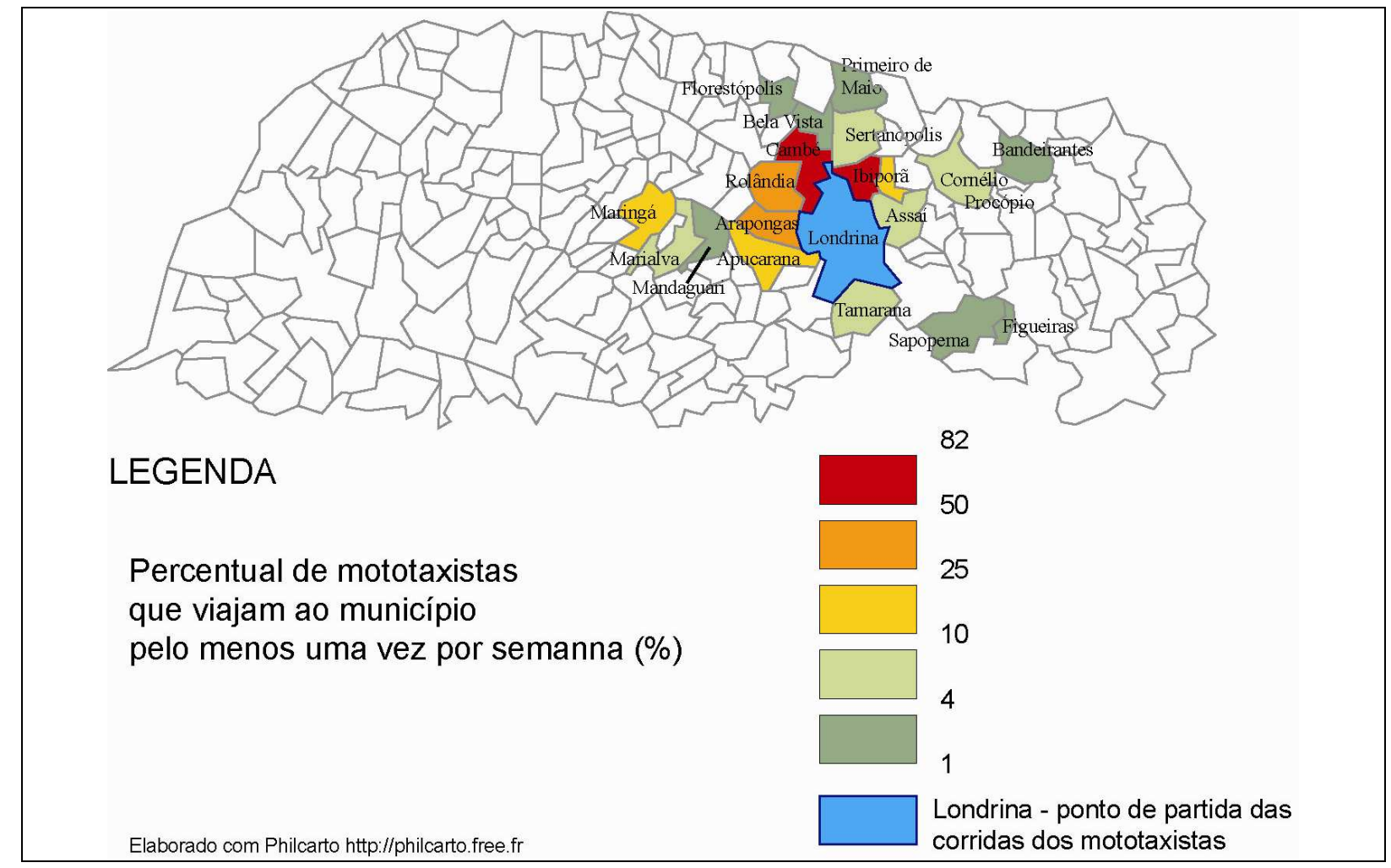

Fonte: Trabalho de campo, 2008

Há um número maior de motoboys que realizam corridas para as cidades próximas a Londrina e que integram a Aglomeração urbana não-metropolitana, a exemplo de Cambé, Ibiporã e Rolândia. As cidades de Apucarana e Maringá também aparecem como destino relativamente freqüente de pelo menos $5 \%$ dos motoboys entrevistados.

No caso dos mototaxistas o padrão de deslocamentos guarda algumas semelhanças com o dos motoboys. Há, por exemplo, um número maior de viagens para os municípios da Aglomeração mais próximos a Londrina: Cambé, Ibiporã e Rolândia. As cidades de Maringá e Apucarana também se destacam como destinos relativamente freqüentes das viagens desses profissionais. Porém, as semelhanças param por aí. 0 mapa relativo às viagens dos mototaxistas revela um número maior de municípios cobertos pelas viagens de pelo menos $4 \%$ desses profissionais. Conseqüentemente, as distâncias percorridas também são maiores, o 
município de Cornélio Procópio, por exemplo, dista $70 \mathrm{~km}$ de Londrina pela BR 369.

Para reproduzir sua atividade os mototaxistas têm de articular elementos da economia urbana de Londrina com outros elementos de cidades vizinhas e de outras não tão próximas. A intermitência e a variabilidade das solicitações de deslocamento a que têm de atender acaba por requerer deslocamentos sobre uma extensão maior do que a coberta pelos motoboys.

A horizontalidade, presente principalmente nos deslocamentos dos mototaxistas, deriva, sobretudo, do acontecer complementar (SANTOS, 2004) que se estabelece entre as cidades da rede urbana regional e também entre cidade e campo.

Indagando sobre os tipos de encomendas que motivavam os deslocamentos para outros municípios verificamos que, tanto para motoboys como para mototaxistas, as peças para automóveis, motos, caminhões e máquinas agrícolas são o principal item que origina esses deslocamentos.

Esse item foi apontado por $61 \%$ dos entrevistados que realizam viagens para outros municípios ${ }^{178}$. Em segundo lugar apareceram peças para diversos aparelhos eletro-eletrônicos (ar condicionado, eletrodomésticos, elevadores, equipamentos de medição, etc.) com $22 \%$ das respostas e em terceiro lugar medicamentos e material para dentistas ${ }^{179}$ com $7 \%$.

Ainda que, em menor proporção do que os mototaxistas, o trabalho dos motoboys no serviço de entregas urbanas também intensifica os fluxos entre Londrina e outras cidades da região.

\footnotetext{
${ }^{178}$ Vale ressaltar que do total de 126 trabalhadores com motocicleta entrevistados, 114 realizavam viagens para outros municípios. Foram 43 motoboys num total de 52 entrevistados (82\%) e 71 mototaxistas em total de 74 entrevistados (95\%)

${ }^{179}$ Os itens peças para aparelhos eletrônicos e medicamentos foram cobertos inteiramente por mototaxistas. Alguns profissionais aproveitavam suas viagens para realizar entregas combinadas de autopeças e peças para assistência técnica. As entregas de medicamentos eram combinadas as de material para tratamento dentário e, no caso dos medicamentos, tratava-se de mototaxistas que tinham contratos para distribuição de produtos de um pequeno laboratório de Londrina nos hospitais da região e também de atacadistas de medicamentos que tinham vencido licitações para fazer esse fornecimento em hospitais da região.
} 


\section{CONCLUSÕES}


A formação e o desenvolvimento dos circuitos da economia urbana em Londrina apresentam particularidades que decorrem, por um lado, do processo de constituição do arranjo espacial regional no contexto do processo de colonização dirigida praticado pela Companhia de Terras, e do modo como esse processo se ajustou às conjunturas recessivas dos anos 1930 e 1940. De outro lado, temos os conteúdos específicos da cafeicultura norte-paranaense, moldando profundamente a formação da economia urbana de Londrina ao longo das décadas de 1950 e 1960.

A principal dentre essas particularidades foi a concentração dos grandes negócios ligados à cafeicultura em Londrina, possibilitando um maior desenvolvimento das forças produtivas naquela cidade e, com isso, a formação de um circuito superior embrionário, mas extremamente dinâmico que extrapolou os limites dos negócios em torno do café e da venda de lotes rurais. Esse circuito superior em formação trouxe, para a cidade, a capacidade de atrair novas atividades que se juntaram ao conjunto.

O capital, sobretudo o capital mercantil e o capital bancário, assentaram-se primeiro em Londrina, ponto central das transações com as safras, da aquisição de bens de consumo e dos negócios com a terra, em suma, da captura das rendas da terra. Desse modo, desenvolveram-se novos capitais no âmbito do comércio varejista, atacadista e intermediação bancária. Também serviços diversificados nas áreas do transporte, comunicação, educação, saúde, lazer, entre outros. A formação de um contingente expressivo de profissionais liberais acompanhou a expansão dos serviços e do comércio. Os serviços públicos e as infraestruturas, produzidos inicialmente sob o comando de capitais privados e posteriormente ampliados e territorialmente integrados pela ação do Estado, deram o suporte necessário à multiplicação e à acumulação dos diversos tipos de capital e, conseqüentemente, também às diversas formas de trabalho que se instalaram na cidade.

As novas atividades que a cafeicultura possibilitou à Londrina ampliaram seus papéis urbanos, fortaleceram sua posição na 
mediação dos fluxos de mercadorias e informações entre o Norte do Paraná e São Paulo; e também com o exterior.

À medida que a vida urbana ganhava novos conteúdos pelo lado do circuito superior, um circuito inferior, ainda mais embrionário que o circuito moderno, estava em formação. A concentração da riqueza e da pobreza no mesmo lugar é uma das conseqüências do processo de urbanização sob o modo de produção capitalista.

Em virtude de, durante o período da cafeicultura, a exploração do trabalho concentrar-se no meio rural, as atividades ligadas à sobrevivência dos pobres da cidade combinavam-se à sazonalidade e à pulsação da produção agrícola e, dessa forma, se apresentavam dispersas e intersticiais no contexto da economia urbana. Entretanto, à medida que a concentração e a centralização dos capitais redefiniam a vida econômica de Londrina, formavam-se as condições para o desenvolvimento de um circuito inferior menos disperso e mais integrado à divisão do trabalho em suas diversas escalas. Contudo, seria necessário que a exploração do trabalho também estivesse concentrada no meio urbano, para que o circuito inferior passasse a se constituir em elemento vital da reprodução social em Londrina. Essa transformação teria de aguardar uma nova inserção regional na divisão territorial do trabalho.

Nos anos 1970, as modernizações que redefiniram a especialização produtiva do Norte do Paraná não se restringiram à substituição do cultivo de café e cereais por lavouras temporárias mecanizadas e pastagens. As novas modernizações atingiram em cheio a divisão de trabalho local, redefinindo os papéis das pequenas cidades e o próprio arranjo espacial regional.

Nisso reside a importância de conhecer a dinâmica do período anterior, isto é, o período da cafeicultura, pois a formação da economia urbana londrinense estava diretamente relacionada à divisão do trabalho local. Os conteúdos e o dinamismo dos circuitos da economia urbana em formação, especialmente do circuito superior, eram provenientes da repartição de tarefas na produção, transporte, 
armazenagem, classificação e comercialização do café entre as cidades da região, e entre as cidades e o meio rural. A ruptura da divisão de trabalho na escala local, significou uma transformação, uma reestruturação da economia urbana londrinense e, portanto, dos circuitos.

É de grande importância enfatizar a base sobre a qual incidiram as modernizações que, a partir dos anos 1970, tornaram maduras as condições para o desenvolvimento dos circuitos. As feições regionais dos circuitos da economia urbana londrinense, tais como a dimensão e a sofisticação de seu comércio varejista, a diversidade dos serviços, a presença de infraestruturas capazes de sustentar fluxos intensos de mercadorias, pessoas e informações, a exemplo do aeroporto da cidade, são, em grande parte, heranças do período da cafeicultura que moldaram o desenvolvimento posterior da economia urbana. Também as dimensões, a diversidade e certo grau de tecnificação do meio construído em Londrina, expresso pelas redes de eletricidade, telefonia e saneamento básico, eram condições do novo período e da consolidação dos circuitos da economia urbana, que foram, em grande parte, herdadas da cafeicultura.

As modernizações inerentes à primeira fase da difusão do meio técnico-científico-informacional, especialmente a agricultura mecanizada, o novo ritmo da industrialização na cidade e a urbanização intensa e concentrada, produziram novas dinâmicas na economia urbana. As transformações nas relações de produção no meio rural, o incremento do assalariamento, a nova repartição de tarefas na escala local, as migrações, são exemplos de algumas rupturas que marcam o momento em que as coerências e a coesão do período da cafeicultura se desfizeram. Novas funções se instalaram e as formas espaciais acompanharam o movimento geral. O meio construído em Londrina e o arranjo espacial regional se transformaram substancialmente.

As concentrações econômica e demográfica se reforçaram, aprofundando a vida de relações e o poder de polarização das cidades maiores e, em sintonia com as novas condições do território, 
aprofundaram também a dependência e as interações de Londrina com o núcleo financeiro e industrial paulista e com o exterior.

No período pós-1970 o circuito superior londrinense incorporou os novos atores hegemônicos que a divisão territorial do trabalho nas escalas nacional e internacional determinou: agroindústrias e cooperativas. Com isso, a economia urbana londrinense ampliou o seu processo de internacionalização mediante a presença de grandes agroindústrias, algumas delas de capital estrangeiro. Esses novos atores reforçaram as feições regionais dos circuitos, sobretudo do circuito superior.

Novos capitais, o capital industrial e o capital financeiro de diversas origens, instalaram-se com mais vigor na cidade, redefinindo a dinâmica da economia urbana. A densidade técnica do meio construído em Londrina atingiu um novo patamar. Novas redes técnicas e uma maior disponibilidade de insumos fundamentais à industrialização e a urbanização acelerada se fizeram presentes na cidade contribuindo para a consolidação dos circuitos.

A consolidação do circuito inferior em meio a esse novo cenário é mais difícil de acompanhar. A economia gerada pelos pobres das cidades não entra com clareza nas estatísticas e nem sempre deixa registros em que se possa confiar.

Seu registro mais fiel é a diversidade do meio construído. A formação de centros de bairro implica que pequenos negócios foram se formando. Os trabalhos sobre a Vila Casoni revelam essa face da vida urbana. Os conjuntos habitacionais espalhados pela cidade que, em geral, acompanharam a localização e distribuição das áreas industriais, deram origem a núcleos de comércio e serviços importantes na formação do novo cotidiano. Os serviços e equipamentos públicos também atuaram nessa nucleação que se distribuiu pelo meio construído e deu margem ao florescimento do circuito inferior.

As modernizações da primeira fase de difusão do meio técnico-científico-informacional também atuaram sobre a consolidação do 
circuito inferior. Boa parte das indústrias que se formaram em Londrina era de pequenos estabelecimentos pertencentes a ramos de baixa intensidade tecnológica (BRAGUETO, 2007). Além disso, eram fortemente integradas ao mercado local e regional.

A ampliação do contingente de trabalhadores urbanos nos anos 1970 e 1980 e sua origem rural, podem ser explicados pelo desenvolvimento da pequena produção mercantil e pelos tipos de relações de trabalho que predominaram na região durante o período da cafeicultura. Havia uma grande massa de migrantes rurais recém chegados à cidade que, por meio das atividades do circuito inferior, puderam encontrar ocupação, obter renda e ver atendidas suas necessidades básicas de consumo. As pesquisas (ALMEIDA, 1980 e CESÁRIO, 1978) sobre a origem dos trabalhadores das pequenas indústrias confirmam esses argumentos.

Ao longo dos anos 1970 e 1980 aumentou o número de empregos assalariados na cidade, $O$ trabalho tornou-se predominantemente urbano e com ele também a reprodução social. A dinâmica de consolidação do circuito inferior possibilitou a absorção de um contingente considerável de trabalhadores ${ }^{180}$, como revela a intensidade de crescimento da PEA urbana.

À consolidação de um circuito superior robusto, verdadeira expressão da divisão territorial do trabalho nas escalas nacional e internacional, correspondeu a consolidação de um circuito inferior organicamente integrado ao cotidiano urbano. Os circuitos são a expressão da divisão capitalista do trabalho no meio urbano e refletem o processo instável e contraditório de reprodução ampliada do capital e de reprodução ampliada da pobreza. Entretanto, convém manter sempre viva a ressalva de que isso não esgota, no caso do circuito inferior, o sentido da luta por se integrar ao modo de vida urbano, o sentido da busca por

\footnotetext{
${ }^{180}$ Ainda hoje, ou seja, em 2009, os maiores geradores de emprego na cidade são atividades instaladas nesse período tais como a Comaves, frigorífico que abate e exporta frangos.
} 
formas de trabalho e ocupação que permitam enfrentar as ameaças do empobrecimento.

As novas especializações produtivas que decorreram das transformações na divisão territorial do trabalho nas escalas nacional e mundial nos anos 1990, incidiram sobre uma economia urbana consolidada. As rupturas que elas produziram afetaram de forma contundente a dinâmica dos circuitos da economia urbana instalada a partir dos anos 1970.

As modernizações dos anos 1990 no contexto do projeto neoliberal incidiram sobre populações inseridas no modo de vida urbano. Esse dado traz implicações para a dinâmica dos circuitos. O novo patamar relativo ao excedente estrutural de trabalhadores implicou a reestruturação do circuito inferior na direção do aumento da intensidade das formas de auto-exploração e da desproteção social.

A segunda fase de difusão do meio técnico-científicoinformacional se apoiou na produção e apropriação privada das novas infraestruturas tornando mais seletivo o seu uso. Parte dos novos sistemas técnicos implantados no Paraná foi controlada pela iniciativa privada, a exemplo da telefonia móvel celular, técnica nova que se mostrou de grande importância na estruturação e funcionamento das atividades do circuito inferior, a partir dos anos 1990.

As verticalidades se aprofundaram e ampliaram o grau de internacionalização da economia urbana, que já não era pequeno nos períodos anteriores. Os atores do circuito superior incorporados à economia urbana londrinense a partir dos anos 1990 possuem menos ligações com a cidade ou a região do que as agroindústrias e cooperativas do período anterior; estão na cidade, todavia, sua integração a ela é restrita.

A nova densidade técnica do meio construído em Londrina, sua diversificação e o impacto das técnicas informacionais na dinâmica dos empregos, na desvalorização de formas de trabalho estabelecidas provocaram novas rupturas nas coerências e coesões construídas ao longo 
do período técnico-científico pós-1970. Essas rupturas reforçaram a dinâmica do circuito inferior e estão na base das jornadas extenuantes de trabalho de motoboys e mototaxistas. Também ajudam a explicar a sombra de instabilidade e insegurança que o risco de acidentes e de não conseguir manter-se na atividade projeta sobre o cotidiano desses trabalhadores.

A redução do número de postos de trabalho, o forte crescimento do número de desempregados e a desvalorização do trabalho, associados ao aumento da circulação e à intensificação dos consumos, tiveram como resposta a reestruturação do circuito inferior.

Essa reestruturação se expressa na criação de novas inserções na divisão social do trabalho que se apoiaram na diversidade, na dimensão e nos constrangimentos do meio construído, e em novas técnicas como o telefone celular. O serviço de Moto Táxi é um exemplo dessas novas inserções.

O pequeno comércio que continuou a se expandir na esteira da diversificação do meio construído e, dessa forma, continuou a responder pelas necessidades de ocupação, já que é uma das atividades que mais emprega pessoas na cidade (RAIS, 2004; IPARDES, 2008), também se enquadra no processo de reestruturação do circuito inferior. Nesse caso, os camelódromos que se consolidaram como formas da expansão do pequeno comércio voltado ao consumo popular, são outros exemplos.

A presença de diversos camelódromos na cidade indica que a reunião de estabelecimentos bem pequenos em um mesmo local, de maneira a reduzir custos de manutenção de cada um deles, tem se mostrado eficiente para evitar que fechem as portas rapidamente. A produção de camelódromos e similares também se mostrou um bom negócio para especuladores imobiliários. Os circuitos se entrelaçam mantendo a subordinação que caracteriza os vínculos entre o circuito superior e o inferior. 
A forma e o funcionamento do Camelódromo de Londrina e do Serviço de Moto Táxi apresentam conteúdos que revelam uma disposição de incorporar elementos das modernizações atuais.

As técnicas modernas não estão ausentes no circuito inferior. É possível usar cartões de débito e crédito para fazer compras em vários estabelecimentos do Camelódromo, bem como voltar para casa utilizando o serviço de um mototaxista acionado a partir de um telefone celular. Ao chegar em casa, a refeição pode ser encomendada pelo telefone e recebida algum tempo depois por meio de um motoboy.

No plano da normatização e do discurso essa tendência se repete, especialmente no que diz respeito à formalização e a flexibilidade como panacéias para os males contemporâneos. As duas atividades, isto é, o pequeno comércio nos camelódromos e o Moto Táxi, apresentam certos traços que indicam sua acomodação frente às normas legais.

Em ambas atividades, a criação de leis que ampararam suas relações com o poder público municipal, geraram exigências de abertura de microempresas, recolhimento de taxas, vistorias e fiscalização. É possível comprar mercadorias com nota fiscal no Camelódromo e verificar que as Centrais de moto táxi são microempresas registradas. Apesar desses traços de formalização as atividades permanecem como formas de perpetuar situações de pobreza e precariedade, especialmente o Moto Táxi. Os traços de formalização presentes nessas atividades pouco contribuem nesse sentido.

O que concluímos em relação a essas observações é que o circuito inferior em Londrina não é o reino da informalidade. Por outro lado, certas propostas de enquadramento das atividades do circuito inferior em padrões de formalidade e observação de exigências legais, podem ter alguma importância do ponto de vista de criar certo grau de aceitação social para a atividade. Contudo, no que se refere à questão central da melhoria das condições de trabalho e de vida a curto e médio prazos, têm eficácia limitada. 
Esse argumento pode ser reforçado pela análise da situação que enfrentam os motoboys. As empresas de entregas urbanas surgiram na cidade no mesmo momento que o Camelódromo e o Moto Táxi, o final dos anos 1990. Essas empresas são grandes intermediadoras da utilização de força de trabalho, aplicada na esfera da circulação, por parte de diversas empresas do circuito superior de Londrina. A peculiaridade da relação das empresas de entregas urbanas com seus trabalhadores, os motoboys, está em que o principal instrumento de trabalho deve ser providenciado pelo trabalhador e não pela empresa. Dessa forma as empresas de entrega urbana não se limitam a explorar a força de trabalho dos motoboys, a relação inclui uma associação entre a força de trabalho do entregador, disponibilizada em uma jornada determinada de trabalho, e um instrumento particular e relativamente caro: a moto.

Em princípio, o motoboy é um trabalhador assalariado com registro formal em carteira que estaria em melhor situação do que seus colegas mototaxistas, que são trabalhadores por conta própria e não contam com nenhuma forma de seguridade social tais como a aposentadoria, a manutenção de algum rendimento em caso de acidente ou doença e outros direitos trabalhistas. Essas conquistas são muito relevantes, mas exigem que a contribuição seja contínua e, no caso da aposentadoria, que ocorra por longos períodos. Na prática, e no curto prazo, para manter-se como assalariado o motoboy tem de realizar muitas horas extras, trabalhar em mais de um local e aos fins de semana para melhorar seus rendimentos e, principalmente poder arcar com as despesas de financiamento da moto.

A superficialidade da oposição formal / informal é um obstáculo a ser superado para se chegar a uma compreensão mais profunda da dinâmica da economia urbana, e em especial das formas de entrelaçamento entre os circuitos.

Outra questão é a flexibilidade que, em geral, é associada à ideologia do negócio próprio. Esses discursos tornam opacas as formas de 
exploração intensa do trabalho que se constroem nas interações entre atividades pertencentes a circuitos diferentes.

Durante as entrevistas com mototaxistas e alguns proprietários do Camelódromo, ouvimos declarações acerca das vantagens dessas atividades: não ter que atender a horários rígidos, não se submeter aos riscos de demissões inesperadas, poder "batalhar para ganhar um pouco mais" em caso de aperto, trabalhar muito duro, mas em algo que é seu, e outras desse gênero. A flexibilidade proporcionada por essas formas de trabalho é um aspecto valorizado por essas pessoas.

Ao mesmo tempo reconhecem que enfrentam situações de grande risco e que não teriam muita chance de voltar a se integrar no mercado formal de trabalho. A limitação se dá, especialmente porque, teriam de enfrentar postos de trabalho com remunerações menores do que as que tiveram no passado, quando eram empregados de alguma empresa, e menores do que as que obtêm hoje, na atividade por conta própria. Então na verdade onde está a flexibilidade? O que move esses trabalhadores não seria uma forma de rigidez imposta pela ameaça do empobrecimento e de ser descartado de vez, não apenas do mercado de trabalho, mas de qualquer ocupação urbana e, portanto, do modo de vida urbano?

Resta ainda, o fato de que, é na imbricação das divisões de trabalho por cima e por baixo que se constrói a funcionalidade das situações que caracterizam as atividades do circuito inferior.

Os motoboys e mototaxistas, isto é, os trabalhadores com moto, atendem às necessidades de rapidez e agilidade na prestação de serviços e na entrega de uma variada gama de documentos e objetos. Como a fluidez é um dos imperativos do período atual (SANTOS, 2004) a tendência de crescimento do número de trabalhadores com motocicletas parece não conhecer obstáculos de monta a curto e médio prazo.

A intensa expansão do número de motos em circulação no Brasil nos últimos anos coincide com o aumento também acelerado de trabalhadores que têm na motocicleta seu principal instrumento de 
trabalho ${ }^{181}$. A ampla difusão desses trabalhadores em todo país, além de corresponder às necessidades de fluidez de diferentes atores da economia urbana, implica o consumo produtivo da motocicleta.

O uso da moto como instrumento de trabalho contribui para o aumento do consumo desse bem. O aumento do número de motos em circulação também está ligado ao crescimento das vendas que, por sua vez, se apóia na expansão do crédito. O uso da moto, técnica incorporada às atividades do circuito inferior, põe em movimento as engrenagens do circuito superior; alimenta o oligopólio que domina o mercado de motos no país ${ }^{182}$.

A presença das motocicletas e de trabalhadores ligados a elas possibilita que certos tipos de fluxos se realizem entre Londrina e outras cidades. Os fluxos, modernos ou não, são importantes na redefinição dos papéis das cidades médias no período atual ${ }^{183}$ e alguns deles se materializam a partir do trabalho de motoboys e mototaxistas.

No capitalismo a produção de mercadorias é a forma generalizada da produção social. Como produção de mercadorias a produção social subordina a existência humana ao consumo que se realiza no mercado e apenas por intermédio dele, isto é, só depois de realizarem o valor de troca, os produtos do trabalho humano, são disponibilizados para o consumo.

181 Em 2008 a produção nacional de motocicletas foi de 2.140 .907 unidades, um crescimento de $237 \%$ em relação a 2000. Em termos absolutos esse crescimento representou nada menos que 1,5 milhão de novas motocicletas. O crescimento da produção foi acompanhado pela expansão do número de motocicletas em circulação no país que passou de 2,5 milhões em 1998 para 11 milhões em 2008. O mesmo processo de expansão ocorreu em Londrina e no Paraná como um todo. (BRASIL, Ministério das Cidades, DENATRAN, 2008)

Os dados sobre a produção de motocicletas foram obtidos no sítio da Associação Brasileira dos Fabricantes de Motocicletas, Ciclomotores, Motonetas, Bicicletas e similares - ABRACICLO Disponível em <http://abraciclo.com.br>; Acesso em 20 de agosto de 2009.

182 Desde o lançamento do modelo "CG Today" de 125 cilindradas em 1976 a Honda domina amplamente o mercado de motocicletas no Brasil. A empresa detém, em média, $80 \%$ das vendas de motos no mercado interno brasileiro que consome preponderantemente veículos com potências de 125 e 150 cilindradas. Disponível em <http://abraciclo.com.br>; Acesso em 20 de agosto de 2009.

183 "Levando em consideração a coexistência e a articulação combinada e desigual de fluxos estabelecidos por sistemas de transporte e de comunicação, reforçando continuidades e gerando descontinuidades territoriais, em função de interações por contigüidade ou por conectividade, como já destacamos no item anterior, passamos a descrever,de modo sucinto, os processos que estão em curso, os quais têm provocado repercussões significativas na redefinição das redes urbanas, em diferentes escalas e, por conseguinte, nos papéis das cidades médias constituintes dessas redes." (SPÓSITO, 2007a, p. 41) 
O consumo em suas diferentes formas (produtivo e final) liga-se à circulação de mercadorias e à distribuição, que por sua vez completam o processo de produção capitalista, que é a unidade formada pelo processo de trabalho e de valorização. A sobrevivência do capitalismo impôs como condição, a revolução constante da produção e do consumo de mercadorias. A mesma condição de permanente revolução pesa, então, sobre as esferas da produção strictu sensu, da circulação e da distribuição.

A intensificação do consumo e da circulação mediados pela ampliação do crédito, pela presença cada vez maior dos bancos e instituições financeiras no cotidiano, inclusive de uma parcela da população pobre, exige trabalho vivo. Não é demais lembrar com Marx (1998, p.109) que "não é com seus pés que as mercadorias vão ao mercado, nem se trocam por decisão própria". Os fluxos que se realizam com base no trabalho de motoboys e mototaxistas de Londrina respondem às necessidades de fazer circular um número crescente de mercadorias, documentos, objetos e informações no contexto da aceleração contemporânea (SANTOS, 2005).

A condição de Londrina como cidade média reflete os papéis de intermediação que a cidade adquire com a implantação de atividades produtivas e de consumo. Os novos papéis e atividades de Londrina se realizam no contexto de uma parte do território brasileiro, a Região Concentrada, em que há grande fluidez e que a divisão interurbana do trabalho é densa. Assim, nessa parte do país, diversos tipos de fluxos se entrecruzam e dentre eles, há os que são realizados a partir de atividades intensivas em trabalho, potencializadas pelas técnicas modernas.

A conclusão que se esboça então é a seguinte: o circuito inferior, por meio dos fluxos efetivados pelos trabalhadores com moto, participa da ampliação e manutenção dos papéis de Londrina enquanto cidade média. Essa participação completa a forma como as verticalidades concentradas no circuito superior, encontram mecanismos de se combinar às horizontalidades propiciadas pelas atividades do circuito inferior, 
fazendo com que a segmentação da economia urbana se reforce com a reestruturação do circuito inferior.

Em Londrina, no período atual, a concentração urbana, em seus aspectos econômico e demográfico, é ainda maior que no período anterior. O cotidiano de Londrina reúne também empresas e pessoas de Cambe, Ibiporã e Rolândia. O trabalho de José Humberto Tavares (2001) demonstra isso com clareza. Uma das conseqüências desse processo é que o meio construído se tornou mais fragmentado e diversificado. Diante dessas condições o circuito inferior ligado ao consumo e à circulação adquire novas escalas e qualidades.

Reside aí uma conclusão importante desta pesquisa. A reestruturação do circuito inferior, a partir dos anos 1990, apoiou-se fortemente no meio construído, mediação fundamental do entrelaçamento dos circuitos.

O circuito inferior no período atual parece integrar-se ainda mais profundamente à cidade: à sociodiversidade (SANTOS, 2004) e à diversidade do meio construído que caracterizam uma cidade média como Londrina. A contigüidade e a proximidade que a cidade propicia entre pequenos negócios, trabalhadores assalariados com diversos tipos de rendimentos, classes médias ligadas a serviços públicos e atividades modernas, desempregados e atividades hegemônicas, possibilita que o circuito inferior possa adequar-se aos espasmos da economia urbana. Ao manter disponível um contingente de trabalhadores para atender as necessidades da aceleração da circulação e da intensificação do consumo contemporâneos o circuito inferior mais uma vez revela sua funcionalidade para a reprodução social e toda a dimensão concreta do sofrimento humano que o acompanha.

Revela também como se viabiliza a vida cotidiana nas áreas mais afastadas, nas periferias da cidade e como a luta dos pobres por se inserir na divisão do trabalho também cria a economia urbana. Os centros de bairro são elementos essenciais para a sobrevivência das Centrais de 
Moto Táxi. A existência desse serviço reduz os atritos e dificuldades da mobilidade intra-urbana.

É em torno do valor de uso complexo do meio construído que as disputas entre o pequeno comércio, em geral rotulado de informal, e os comerciantes organizados na associação patronal se mostram mais candentes.

O Centro Principal de Londrina é também o centro de uma região cujos limites são difíceis de precisar, mas que se estende pelo norte do Estado e até para além das fronteiras do Paraná. A centralidade de Londrina (SILVA, 2006) implica em fluxos que fazem do Centro Principal um local mais do que favorável ao comércio e aos serviços.

A concorrência entre os camelódromos e as lojas tradicionais que disputam os fluxos de consumidores que convergem para o centro de Londrina acirra os conflitos entre esses atores em relação ao meio construído e é um móvel da reestruturação do circuito inferior. Para sobreviver os pequenos comerciantes dos camelódromos tiveram de se tornar mais parecidos com seus concorrentes, equipar o Camelódromo com ar condicionado e escada rolante, aceitar meios eletrônicos de pagamento, aumentar a participação de mercadorias compradas de acordo com os tramites legais e misturá-las as mercadorias compradas de maneira "informal" como fazem os outros comerciantes, entre outras práticas.

Essa tendência aumentou as chances de sobrevivência dos estabelecimentos, permitiu ganhos maiores, fez surgir um grupo de rentistas que vive do aluguel dos boxes e também acabou por expropriar muitos daqueles que viveram os dias de embate nas ruas com a Prefeitura, o Ministério Público e a Polícia federal. Não foram poucos os que se tornaram novamente camelôs nas ruas e os que se tornaram empregados de outros comerciantes no próprio Camelódromo.

Para terminar é importante apontar algumas diferenças que o circuito inferior de Londrina no período atual apresenta em relação ao circuito inferior tal como analisado por Milton Santos nos anos 1970, para 
as grandes cidades do Terceiro Mundo. É preciso que ressaltemos que as diferenças se explicam tanto pelo período que é outro, em relação aos anos 1970, quanto pelo contexto local e regional; trata-se do circuito inferior de Londrina, o que implica considerar suas feições regionais.

As diferenças que constatamos dizem respeito, sobretudo, às características dos trabalhadores do circuito inferior. Uma primeira diferença diz respeito ao grau de escolaridade desses trabalhadores. A falta de escolaridade ou escolaridade insuficiente não é exatamente uma característica marcante dos trabalhadores do circuito inferior em Londrina. Considerando a totalidade dos entrevistados a grande maioria estudou até o ensino médio e praticamente a metade dos entrevistados concluíram esse nível de ensino.

Outra diferença é que a maioria dos trabalhadores do circuito inferior não é de migrantes recém-chegados à cidade. A maioria dos entrevistados mora em casa própria, sua ou dos pais. Os seus domicílios são apetrechados com diversos equipamentos domésticos. Estão distribuídos em bairros em que predominam responsáveis pelo domicilio com rendimentos mensais baixos, isto é, até dois salários mínimos. No caso dos trabalhadores em atividades por conta própria, verificamos que praticamente a totalidade dos entrevistados teve uma trajetória pelo mercado formal de trabalho.

Os próprios trabalhadores do circuito inferior são atendidos pelas atividades do circuito inferior, constituindo uma circularidade que nada tem de acidental, que mais uma vez, a exemplo do que ocorria no período anterior, se mostra funcional ao modo de produção. Isso não é novo, mas se apresenta de forma ainda mais intensa e mais difundida na cidade e na região.

O circuito inferior continua a ser um perpetuador da pobreza e, simultaneamente, representa formas de luta contra o empobrecimento e contra as irracionalidades da racionalidade hegemônica. O circuito inferior está relacionado às lógicas da sobrevivência, mas também 
participa das formas de alienação e de exploração do trabalho que alimentam a intensificação da circulação e dos consumos.

A teoria dos circuitos mostra que a divisão do trabalho é uma categoria central para a compreensão mais profunda da cidade e do urbano no período atual, pois é por meio da análise da divisão do trabalho em suas várias escalas que a dinâmica dos circuitos se revela e, com ela, o modo como os circuitos participam da reprodução social.

No período atual, analisar as transformações dos circuitos como manifestações da divisão do trabalho ajuda a não perder de vista a compreensão da cidade com base na totalidade e a exorcizar os discursos que se erguem sobre parcialidades e que intencionalmente obliteram dimensões e aspectos fundamentais do modo de vida urbano. 
REFERÊNCIAS BIBLIOGRÁFICAS 


\section{REFERÊNCIAS}

ADORNO, Theodor W.; HORKHEIMER, Max. Dialética do

Esclarecimento. Rio de Janeiro: Zahar, 1985.

ADUM, Sonia. Imagens do progresso: civilização e barbárie em Londrina, 1930 - 1960. 1991. 227 f. Dissertação (Mestrado em História) - Departamento de História, UNESP, Assis.

AGÊNCIA ESTADO. [Número de motociclistas no Brasil]. O Estado de São Paulo. São Paulo, [2009?]. Disponível em:

<http://www.estadao.com.br/estadaodehoje>. Acesso em: 15 jul. 2009.

ALMEIDA, Ana Maria Chiarotti de. Dinâmica Participação social dos operários de origem rural em área urbana: Londrina - PR. 1980. 110 f. Tese (Pós-Graduação em Economia Rural) - Centro de Estudos e Pesquisas Econômicas, Faculdade de Ciências Econômicas, Universidade Federal do Rio Grande do Sul, Porto Alegre.

ALVES, Claudia Lima E. Dinâmica espacial de produção e reprodução do capital e da força de trabalho em Londrina: conjuntos habitacionais. 1991. 188 f. Dissertação (Mestrado em Geografia Humana) - Departamento de Geografia, Universidade de São Paulo, São Paulo.

ARIAS NETO, José Miguel. O Eldorado: Londrina e o Norte do Paraná, 1930-1975. 1993. 235 f. Dissertação (Mestrado em História) Departamento de História, Universidade de São Paulo, São Paulo.

ARRANJO PRODUTIVO LOCAL TECNOLOGIA DA INFORMAÇÃO LONDRINA E REGIÃO. [Dados]. Londrina: APLTI, 2006. Disponível em:

<www.apltilondrina.com.br>. Acesso em 20 mar. 2008.

ASARI, Alice Atiyo; TUMA, Magda Madalena. Aspectos históricos, Físicos, Econômicos e Institucionais do Município de Londrina. Londrina: Prefeitura Municipal, 1978.

ASSOCIAÇÃO BRASILEIRA DOS FABRICANTES DE MOTOCICLETAS, CICLOMOTORES, MOTONETAS, BICICLETAS E SIMILARES. ABRACICLO:

Banco de Dados. Disponível em: <http://abraciclo.com.br/>. Acesso em: 15 mar. 2009.

ASSOCIAÇÃO COMERCIAL E INDUSTRIAL DE LONDRINA. Setenta anos de união e luta: a história e as conquistas da Associação Comercial e Industrial de Londrina, uma entidade que nasceu quando o Norte do Paraná era apenas sertão. Londrina: Midiograf, 2007. 
ASSOCIAÇÃO NACIONAL DAS EMPRESAS DE TRANSPORTES URBANOS (NTU). Transporte informal urbano: riscos de não encarar o problema de frente. São Paulo: NTU, 1997. Disponível em: <http//www.ntu.org.br/.../publicacoes/>. Acesso em 01 jul. 2008.

AUGUSTO, Maria Helena O. Intervencionismo Estatal e Ideologia desenvolvimentista. São Paulo: Símbolo, 1978.

BARONI, Célia. Obra no Camelódromo sairá em dezembro. Folha de Londrina, Londrina, 14 nov. 1997. Disponível em:

<http://www.bonde.com.br/folha/folhad.php>. Acesso em: 18 de jul. 2008.

BARROS, Mirian Vizintin Fernandes, et al. Atlas Ambiental da Cidade de Londrina. Londrina: IMAP\&P, 2008. Disponível em:

<http://www.uel.br/revistas/atlasambiental/>. Acesso em: 5 maio 2008.

BAUDRILLARD, Jean. A sociedade de consumo. Lisboa: Edições70, 2007.

BAUMAN, Zygmunt. Vida para consumo: a transformação das pessoas em mercadoria. Rio de Janeiro: Zahar, 2008.

BERNARDES, Lysia Maria C. Crescimento da população do Estado do Paraná. In: FRESCA, Tânia M.; CARVALHO, Márcia S. de. Geografia e Norte do Paraná: um resgate histórico, v. 2. Londrina: Humanidades, 2007.

BLUM, Luciane. O desenvolvimento da atividade comercial varejista: o caso de Londrina-PR. 2006. 134 f. Dissertação (Mestrado em Desenvolvimento Regional e Urbano) - Centro de Filosofia e Ciências Humanas, Universidade Federal de Santa Catarina, Florianópolis.

BRAGUETO, Claudio Roberto. A Inserção da microrregião geográfica de Londrina na divisão territorial do trabalho. 1996. $323 \mathrm{f}$. Dissertação (Mestrado em Geografia Humana) - Departamento de Geografia, Universidade de São Paulo, São Paulo.

O aglomerado urbano industrial de Londrina: sua constituição e dinâmica industrial. 2007. 265 f. Tese (Doutorado em Geografia Humana) - Departamento de Geografia, Universidade de São Paulo, São Paulo.

BRASIL. Ministério das Cidades, Departamento Nacional de Trânsito. Frota de veículos. 2008. Disponível em: <http://www.denatran.gov.br/frota.htm>. Acesso em: 23 jun. 2009. 
. Ministério do Trabalho e Emprego. Base Estatística RAIS:

relação anual de informações sociais - RAISESTAB 2003. Brasília, 2004. CDROM.

. Ministério do Trabalho e Emprego. Base Estatística RAIS:

relação anual de informações sociais - RAISESTAB 2004. Brasília, 2004. CDROM.

CACCIAMALI, Maria C. Globalização e processo da informalidade. Economia e Sociedade, Campinas, n. ${ }^{\circ}$ 14, p. 153-174, jun. 2000.

. Um estudo sobre o setor informal urbano e formas de participação na produção. 1982. 234 f. Tese (Doutorado em Economia) - Faculdade de Economia e Administração, Universidade de São Paulo, São Paulo.

CANCIAN, Nadir Aparecida. Cafeicultura paranaense (1900 - 1970): estudo de conjuntura. 1977. 386 f. Tese (Doutorado em história) Departamento de História, Universidade de São Paulo, São Paulo.

CANO, Wilson. Soberania e política econômica na América Latina. São Paulo: Editora UNESP, 2000.

CARDOSO, Fernando H.; FALETO, Enzo. Dependência e desenvolvimento na América Latina. Rio de Janeiro: Zahar, 1973.

CARIOLA, Cecilia; LACABANA, Miguel. Caracas metropolitana: exclusión social, pobreza y nueva pobreza en el contexto de las políticas neoliberales. Cuadernos del Cendes, Caracas, v. 21, n. 56, p.145-153, ago. 2004.

CARVALHO, Márcia Siqueira de. A pequena produção de café no Paraná. 1991. 192 f. Tese (Doutorado em Geografia Humana) Departamento de Geografia, Universidade de São Paulo, São Paulo.

CASTEL, Robert. As metamorfoses da questão social: uma crônica do salário. Petrópolis: Vozes, 1998.

CAVECHINI, Caio; SOUZA, Francisco de; PAGANOTTI, Ivan. A esperança na garupa. São Paulo: Universidade de São Paulo - Escola de Comunicações e Artes, 2004. Disponível em: <http://www.ville-enmouvement.com/concours_etudiant/concours3/ kitprestelechargement/portugueselow.pdf>. Acesso em 25: abr. 2008.

CERVI, Emerson. Eleito vai desocupar praça tombada. Folha de Londrina, Londrina, 22 out. 2000. Disponível em: <http://www.bonde.com.br/folha/folhad.php>. Acesso em: 18 jul. 2008. 
CESÁRIO, Ana Cleide C. Industrialização e Pequenos empresários em Londrina. 1978. 190 f. Dissertação (Mestrado em Ciências Sociais) Departamento de Ciências Sociais, Universidade e São Paulo, São Paulo.

CLARK, Colin. The Conditions of Economic Progress. Londres: Macmillan Co., 1940.

COMPANHIA PARANAENSE DE ENERGIA ELÉTRICA; UNIVERSIDADE FEDERAL do PARANÁ. Um século de eletricidade no Paraná. Curitiba: Companhia Paranaense de Energia Elétrica, 1994.

CORREA, Roberto Lobato. O espaço urbano. 3 ed. São Paulo: Ática, 1995.

2001.

. Trajetórias Geográficas. 2 ed. Rio de Janeiro: Bertrand Brasil,

CUNTO, Adriana de. Câmara decidirá futuro do Moto Táxi. Folha de Londrina, Londrina, 19 abr. 1997. Disponível

em: <http://www.bonde.com.br/folha/folhad.php>. Acesso em: 19 de set. 2008.

DAMIANI, Amélia Luisa. A cidade desordenada: concepção e cotidiano do conjunto habitacional Itaquera I. 1993. $344 \mathrm{f}$. Tese (Doutorado em Geografia Humana) - Depto. de Geografia, Universidade de São Paulo, São Paulo.

DRAIBE, S. As Políticas sociais brasileiras: diagnósticos e perspectivas. In: IPEA. Para a década de 90: prioridades e perspectivas de políticas públicas. Brasília, IPEA, 1989.

ENDLICH, Ângela Maria. Maringá e a rede urbana regional: conteúdo urbano e concentração demográfica. Acta Scientiarum Technology, Maringá, vol. 21, n. 4 p.897-907, 1999.

ESPÍNDOLA, Marcos. CMTU inicia hoje reformas no novo camelódromo. Folha de Londrina, Londrina, 16 set. 2002. Disponível em:

<http://www. bonde.com.br/folha/folhad. php?id=10877\&dt=20020916>. Acesso em: 18 jul. 2008.

FÉLIX, Rosana. PR tem 900 mil no trabalho informal. Folha de Londrina, Londrina, 26 abr. 2001. Disponível em:

<http://www.bonde.com.br/folha/folhad.php>. Acesso em: 18 jul. de 2008.

FERNADES, Florestan. A Revolução Burguesa no Brasil: ensaio de interpretação sociológica. 3 ed. Rio de Janeiro: Guanabara, 1987. 
FONSECA, Natasha Ramos R. Sobre duas rodas: o mototáxi como uma invenção de mercado. 2005. 113 f. Dissertação (Mestrado em Ciências Estatísticas) - ENCE/IBGE Curso de Mestrado em Estudos Populacionais e Pesquisas Sociais, Rio de Janeiro. Disponível em: <http://www.ence.edu.br/pos_graduacao/mestrado/dissertacoes/pdf/200 5/natasha_reis_da_fonseca_TC.pdf>. Acesso em: 23 abr. 2008.

FRAZÃO, Marcelo. Camelôs comemoram crescimento da atividade. Jornal de Londrina, Londrina, 03 ago. 2006. Disponível em:

<http://canais.rpc.com.br/jl/geral/conteudo.phtml?id=587954>. Acesso em: 12 jun. 2007.

FRESCA, Tania Maria. A rede urbana do Norte do Paraná. Londrina: Eduel, 2004.

FUNDAÇÃO GETÚLIO VARGAS. Banco de Dados. Rio de Janeiro: FGV, 1960- . Disponível em: <www.fgvdados.br>. Acesso em: 12 jun. 2009.

FURTADO, Celso. Análise do Modelo Brasileiro. Rio de Janeiro: Civilização Brasileira, 1972.

Terra, 1974.

O mito do desenvolvimento econômico. Rio de Janeiro: Paz e

GAUDEMAR, Jean Paul. Mobilidade do trabalho e acumulação de capital. Lisboa: Estampa, 1977.

GEORGE, Pierre. Geografia Urbana. São Paulo: DIFEL, 1983.

. Sociologia e Geografia. Rio de Janeiro: Forense, 1969.

GOTTDIENER, Mark. A produção social do espaço urbano. São Paulo: Edusp, 1993.

GOUVEIA, Guilherme. Comerciantes de Londrina pedem saída de camelôs. Folha de Londrina, Londrina, 08 maio 2001. Disponível em: <http://www.bonde.com.br/folha/folhad.php>. Acesso em: 18 jul. 2008.

GUNDER FRANK, André. Acumulação dependente e subdesenvolvimento. São Paulo: Brasiliense, 1980.

HARVEY, David. A condição pós-moderna. São Paulo: Loyola, 1992.

. Los Limites Del capitalismo y la Teoría Marxista. Ciudad del Méjico: Fondo de Cultura Económica, 1990.

HORTA, Lúcio. Mototaxistas querem legalizar serviço. Folha de Londrina, Londrina, 11 nov. 1998. Disponível em:

<http://www.bonde.com.br/folha/folhad.php>. Acesso em: 19 set. 2008. 
INSTITUTO BRASILEIRO DE GEOGRAFIA E ESTATÍsTICA. Censo Demográfico - 2000. Rio de Janeiro: FIBGE. Disponível em: <http://biblioteca.ibge.gov.br/>. Acesso em: 03 maio 2008.

. Censo Demográfico: Paraná - 1960. Rio de Janeiro: FIBGE. Disponível em: <http://biblioteca.ibge.gov.br/>. Acesso em: 03 maio 2008.

Censo Demográfico: Paraná - 1970. Rio de Janeiro: FIBGE. Disponível em: <http://biblioteca.ibge.gov.br/>. Acesso em: 03 maio 2008.

Censo Demográfico: Paraná - 1980. Rio de Janeiro: FIBGE. Disponível em: <http://biblioteca.ibge.gov.br/>. Acesso em: 03 maio 2008.

. Censo Demográfico: Paraná - 1991. Rio de Janeiro: FIBGE. Disponível em: <http://biblioteca.ibge.gov.br/>. Acesso em: 03 maio 2008.

. Censos Econômicos: Paraná - 1960 a 1985. Rio de Janeiro: FIBGE. Disponível em: <http://biblioteca.ibge.gov.br/>. Acesso em: 03 maio 2008.

Perfil dos Municípios Brasileiros 2008. Rio de Janeiro, 2008.

IMAGENS, PAISAGENS E PERSONAGENS (Grupo de Pesquisa).

Crescimento do Perímetro Urbano de Londrina. Relatório final de pesquisa. 1999. 36 f. Londrina: IMAP\&P; CPG/UEL, 1999.

INSTITUTO PARANAENSE DE DESENVOLVIMENTO ECONÔMICO E SOCIAL. BDEWeb: base de dados do Estado. Curitiba: IPARDES, 2008. Disponível em: <http\\www. ipardes.gov.br/imp/índex/.php>. Acesso em: 21 mar. 2008.

Edison Vieira, 1983.

Nova Configuração Espacial do Paraná. Curitiba: Fundação

INSTITUTO DE PESQUISA ECONÔMICA APLICADA. Diagnóstico do Setor de Saneamento: Estudo Econômico e Financeiro. Brasília: Ministérios do Planejamento e Orçamento, 1995.

JOFFILY, José. Londres-Londrina. Rio de Janeiro: Paz e Terra, 1985.

KROETZ, Lando Rogério. A História da Telefonia no Paraná. Curitiba: TELEPAR, 1982.

LACOSTE, Yves. Geografia: isso serve em primeiro lugar para fazer a guerra. Campinas: Papirus, 1988. 
LAUDES. A experiência do Paraná. Petrópolis: Vozes, [1971?].

LAUTIER, Bruno. Fixation restreinte dans le salariat, secteur informel et politique d'emploi em Amerique Latine. Revue Tiers Monde, Paris, $v$. XXVIII, n. 110, p. 347 - 367, abr.-jun. 1987.

LEÃO, Silvana. Camelôs continuam sem local definido. Folha de Londrina, Londrina, 2 nov. 2000. Disponível em: <http://www.bonde.com.br/folha/folhad.php>. Acesso em: 18 jul. 2008.

LEÃO, Silvana. Trabalho arriscado. Folha de Londrina, Londrina, 30 jul. 1999. Disponível em: <http://www.bonde.com.br/folha/folhad.php>. Acesso em: 18 jul. 2008.

LINARDI, Maria Cecília N. Pioneirismo e modernidade: a urbanização de Londrina-PR. 1995. 240 f. Tese (Doutorado em Geografia Humana) Departamento de Geografia, Faculdade de Filosofia Letras e Ciências Humanas, Universidade de São Paulo, São Paulo.

LIPOVETSKY, Gilles. A felicidade paradoxal: ensaios sobre a sociedade de hiperconsumo. São Paulo: Companhia das Letras, 2007.

LONDRINA; CODEL. Cadernos Setoriais: indústrias. Londrina: Companhia de Desenvolvimento de Londrina, 2004. Secretaria Municipal de Planejamento. Dados Estatísiticos de Londrina. Londrina: Prefeitura Municipal de Londrina, 1974.

; __ Secretaria Municipal de Planejamento. Perfil Londrina 1986. Londrina: Prefeitura Municipal de Londrina, 1986. ; __ Secretaria Municipal de Planejamento. Perfil Londrina 1987. Londrina: Prefeitura Municipal de Londrina, 1987.

; __. Secretaria Municipal de Planejamento. Perfil Londrina 2007. Londrina: Prefeitura Municipal de Londrina, 2007.

; IPAC. Onde o bairro é a casa. Londrina: COCITEC/UEL, 1987.

LONDRIX. [Notícias]. Londrina: [s/n], 2006. Disponível em: $<$ http://www.londrix.com/noticias.php?id=18297>. Acesso em: 15 jul. 2008.

LOPES, Claudia. Região de Londrina tem 101 mil sem trabalho, diz estudo. Folha de Londrina, Londrina, 23 maio 1998. Disponível em: <http://www.bonde.com.br/folha/folhad.php>. Acesso em: 18 jul. 2008. 
LOPES, Eugenia. Senado aprova regulamento a profissões que usam moto. Estado de São Paulo. São Paulo, 8 jul. 2009. Disponível em: <http://www.estadao.com.br/geral/not_ger399939,0.htm>): Acesso em 9 jul. 2009.

LUGNANI, Antonio Carlos; MARANDOLA, Maria Eduvirges. Cooperativas Agropecuárias no Norte do Paraná: crescimento e capitalização da Valcoop e da Corol no período 1970-98. Revista Paranaense de Desenvolvimento, Curitiba, n. 101, p. 53-70, jul./dez. 2001

LUKÁCS, Georg. História e consciência de classe. São Paulo: Martins Fontes, 2003.

MALAGUTI, Manoel Luiz. Crítica a razão informal: a imaterialidade do salariado. São Paulo: Boitempo, 2000.

MAMANI, Hernán Armando. Alternativo, informal, irregular ou ilegal? O campo de lutas dos transportes públicos. In: PINHEIRO, Ana Clara T. R. EI rostro urbano de América Latina. O rosto urbano da América Latina. CLACSO, Consejo Latinoamericano de Ciencias Sociales, Ciudad Autónoma de Buenos Aires, Argentina. 2004. Disponível em:

<http://bibliotecavirtual.clacso.org.ar/ar/libros/rural1/p6art2.pdf >. Acesso em: 10 jul. 2008.

MARCUSE, Herbert. A ideologia da sociedade industrial. 5 ed. Rio de Janeiro: Zahar, 1979.

MARTINS, José de Souza. O cativeiro da terra. São Paulo: Ciências Humanas, 1979.

MARX, Karl. O capital: crítica da economia política, livro I, v. 1. Rio de Janeiro: Civilização Brasileira, 1998.

MAZZINI, Fernanda. Novo camelódromo será inaugurado no $2^{\circ}$ semestre. Folha de Londrina, Londrina, 24 maio 2006. Disponível em: <http://www.bonde.com.br/folha/folhad.php>. Acesso em: 18 jul. 2008.

MENEGUEL, Stella. Empresa Indiana espera faturar até US\$ 15 milhões em Londrina. Jornal de Londrina, Londrina, 16 out. 2008. Disponível em: <http://portal.rpc.com.br/jl/geral/conteudo.phtml?id=818244>. Acesso em: 30 jul. 2009.

MERRICK, T. Employment and earnings in the informal sector in Brazil: the case of Belo Horizonte. Journal of Developing Areas, Nashville, (EUA), v. 10, n. 3, p. 337-353, 1976. 
MONBEIG, Pierre. A zona pioneira do Norte do Paraná. In FRESCA, Tânia M.; CARVALHO, Márcia S. de. Geografia e Norte do Paraná: um resgate histórico, v. 2. Londrina: Humanidades, 2007.

. Novos estudos de Geografia Humana. São Paulo: Difusão Européia do Livro, 1957.

MONTENEGRO, Marina Regitz. O circuito inferior da economia urbana em São Paulo no período da globalização. 2006. 203 f. Dissertação (Mestrado em Geografia Humana) - Departamento de Geografia, Universidade de São Paulo, São Paulo.

MORAIS, Luka. Mototaxistas: queremos trabalhar. Folha de Londrina, Londrina, 26 abr. 1997. Disponível em:

<http://www.bonde.com.br/folha/folhad.php>. Acesso em: 19 set. 2008.

MOREIRA, Ruy. Pensar e Ser em Geografia: ensaios de história, epistemologia e ontologia do espaço geográfico. São Paulo: Contexto, 2007.

MÜLLER, Nice Lecocq. Contribuição ao estudo do Norte do Paraná. In: FRESCA, Tânia M.; CARVALHO, Márcia S. de. Geografia e Norte do Paraná: um resgate histórico, v. 2. Londrina: Humanidades, 2007.

NAKAGAWARA, Yoshiya. As funções regionais de Londrina e sua área de influência. 1972. 307 f. Tese (Doutorado Geografia Humana) Departamento de Geografia, Universidade de São Paulo, 1972.

NANTES, Ailton da Silva. Segregação espacial: a Vila Nova de Londrina-PR. 2003. 85 f. Monografia (Bacharelado em História) Departamento de História, Universidade Estadual de Londrina, Londrina.

OLIVEIRA, Edílson Luis de. A iniciativa privada e o parcelamento do solo na expansão de Londrina de 1970 a 2000. In I CIMDEPE - Simpósio Internacional Cidades Médias: dinâmica econômica e produção do espaço urbano, (1), 2005, Presidente Pudente - SP, UNESP, GASPERR, 1 CD-ROM.

. A "praia" que faltava em São Paulo. In: RODRIGUES, Adyr A. B.. (Org.). Turismo e Geografia: Reflexões teórica e enfoques regionais. São Paulo: HUCITEC, 1996, p. 247-261.

; FRESCA, Tânia Maria. A produção do espaço urbano de Londrina - 1970 a 2000. 2005. 147 f. Universidade Estadual de Londrina, Relatório de Pesquisa. Londrina, mimeografado.

OLIVEIRA, Francisco de. Crítica à razão dualista. São Paulo: Boitempo, 2003. 
PADIS, Pedro Calil. Formação de uma economia periférica: o caso do Paraná. 2 ed. São Paulo: Hucitec, 1984.

PAULINO, Eliane Tomiasi. Terra e Vida: a geografia dos camponeses do Norte do Paraná. 2003. 430 f. Tese (Doutorado em Geografia Humana) - Faculdade de Ciências e Tecnologia, UNESP, Presidente Prudente.

PAYES, Antonio Mungüia. O Norte do Paraná: expansão cafeeira e apropriação da rena fundiária desde fins do século XIX até 1960. 1984. 173 f. Dissertação (Mestrado em Ciências Sociais) - Instituto de Ciências Humanas e Sociais, Universidade Federal Rural do Rio de Janeiro.

PEGORARO, Paulo. Camelódromo perde freguesia. Folha de Londrina, Londrina, 04 fev. 1999. Disponível em:

<http://www.bonde.com.br/folha/folhad.php>. Acesso em: 18 jul. 2008.

PELEGRINO, Erika. Camelôs querem Shopping no centro. Folha de Londrina, Londrina, 20 abr. 2001. Disponível em:

<http://www.bonde.com.br/folha/folhad.php>, Acesso em: 18 jul. 2008.

PEREIRA, L. B.; LUGNANI, Antonio Carlos. Novos rumos da agricultura paranaense na década de 80. Estudos Econômicos, São Paulo: USP/IPE, v. 21 , n. 3, p. 351-378, set./dez.1991.

PERIS, Alfredo Fonseca; LUGNANI, Antonio Carlos. Um estudo sobre o eixo Cascavel - Foz do Iguaçu, na região oeste do Paraná. Revista

Paranaense de Desenvolvimento, Curitiba, n. 104, p. 79-102, jan./jun. 2003

PESQUISA EMPREGO E DESEMPREGO. São Paulo: DIEESE, 1984- . Disponível em: <www.dieese.org.br/ped/bd/mercadotrab.xml>. Acesso em: 18 jun. 2009.

PINTAUDI, Silvana. Os Shopping-Centers Brasileiros e o Processo de Valorização do Espaço Urbano. Boletim Paulista de Geografia, São Paulo, n. 65, p. 29-45, 2 sem. 1987.

POCHMANN, Márcio. Economia solidária no Brasil: possibilidades e limites. Brasília: IPEA, 2004. Disponível em: <www.ipea.gov.br>. Acesso em: 25 mar. 2009.

. O emprego na globalização: a nova divisão internacional do trabalho e os caminhos que o Brasil escolheu. São Paulo: Boitempo, 2001.

. O emprego no desenvolvimento da nação. São Paulo: Boitempo, 2008. . O trabalho sob fogo cruzado. São Paulo: Contexto, 1999. 
PRANDINI, Neyde. Aspectos da Geografia Urbana de Londrina. In FRESCA, Tânia M.; CARVALHO, Márcia S. de. Geografia e Norte do Paraná: um resgate histórico, v. 2. Londrina: Humanidades, 2007.

PREBISCH, Raúl. Capitalismo Periférico: Crisis y Transformación. México: Fondo de Cultura Económica, 1981.

QUÍCOLI, Paulo Cesar. A formação e a ocupação de um bairro de Londrina: o exemplo da Vila Nova. 1984. 93 f. Monografia (Bacharelado em Geografia) - Departamento de Geociências, Universidade Estadual de Londrina, Londrina.

RAZENTE, Nestor. Acordo de Cooperação Paraná/BIRD: recriando as relações intergovernamentais através do financiamento do desenvolvimento urbano. 2003. 358 f. Tese (Doutorado em Arquitetura) - Faculdade de Arquitetura e Urbanismo, Universidade de São Paulo, São Paulo.

Ocupação do Espaço Urbano de Londrina. 1983, 2 v. 389 f. Dissertação (Mestrado em Desenvolvimento Urbano) - Faculdade de Arquitetura e Urbanismo, Universidade Federal de Pernambuco, Recife.

RIOS, José Arthur. Londrina, uma análise sociológica. Rio de Janeiro: Prefeitura Municipal de Londrina, 1980.

RODRIGUES, Betânia. CMTU estuda alternativas para camelôs. Folha de Londrina, Londrina, 13 jul. 2000. Disponível em:

<http://www.bonde.com.br/folha/folhad.php>, Acesso em: 18 jul. 2008.

RONQUI, Erci Josefina. A modernização no Campo - Londrina/Pr. 1990. 83 f. Monografia (Bacharelado em Geografia) - Departamento de Geociências, Universidade Estadual de Londrina, Londrina.

SALAMA, Pierre. O Tamanho da Pobreza: economia política da distribuição de renda. Rio de Janeiro: Garamond, 1999.

SANFELIU, Carmen B.; TORNÉ, Josep Maria L. Miradas a otros espacios urbanos: Las ciudades intermedias. Revista Electrónica de Geografia Ciencia Sociales. Universidad de Barcelona, v. VIII, n. 165, maio 2004.

SANTOS, Milton. A Natureza do Espaço: Técnica e Tempo, Razão e Emoção. 4.ed. São Paulo: Edusp, 2004.

A Urbanização Brasileira. São Paulo: Hucitec, 1996.

. Da Totalidade ao Lugar. São Paulo: Edusp, 2005.

. Les Villes du Tiers Monde. Paris:M. Th Genin-Libraries

Techniques, 1971. 
. O espaço dividido: os dois circuitos da economia urbana dos países subdesenvolvidos. Rio de Janeiro: Francisco Alves, 1979.

. Pensando o Espaço do Homem. São Paulo: Hucitec, 1982.

1994.

. Por uma Economia Política da Cidade. São Paulo: Hucitec,

. Espaço e Método. São Paulo: Nobel, 1992.

. Por uma outra globalização: do pensamento único à consciência universal. 17.ed., Rio de Janeiro: Record, 2008.

; SILVEIRA, Maria Laura. Brasil: território e sociedade no início do século XXI. Rio de Janeiro: Record, 2001.

SANTOS, Theotonio dos. A Teoria da Dependência: balanço e perspectivas. Rio de Janeiro: Civilização Brasileira, 2000.

SAUER, Sid. Prefeitura teme aumento de Camelôs. Folha de Londrina, Londrina, 03 maio 1998. Disponível em:

<http://www.bonde.com.br/folha/folhad.php>. Acesso em: 18 jul. 2008.

SCHUSTER, Z. SANEPAR Ano 30. Curitiba: Arché, 1994.

SEN, Amartya Kumar. Desenvolvimento como liberdade. São Paulo: Companhia das Letras, 2000.

SILVA, William Ribeiro da. Descentralização e redefinição da

Centralidade em e de Londrina. 2002. 190 f. Dissertação (Mestrado em Geografia Humana) - Faculdade de Ciências e Tecnologia, UNESP, Presidente Prudente.

. Para além das cidades, centralidades e estruturação

urbana: Londrina e Maringá. 2006. 265 f. Tese (Doutorado em Geografia Humana) - Faculdade de Ciências e Tecnologia de Presidente Prudente, UNESP, Presidente Prudente.

SILVEIRA, Maria Laura. Argentina: do desencantamento da modernidade à força dos lugares. In: (org.). Continente em chamas:

globalização e território na América Latina. Rio de Janeiro: Civilização Brasileira, 2005.

. Globalização, trabalho, Cidades Médias. Geo UERJ, Rio de Janeiro, n. 11, p.11-17, 1 sem. 2002.

. Globalizacion y circuitos de la economia urbana en ciudades brasileñas. Cuadernos del CENDES. Caracas, ano 21, n. 57, p.1-21, set./dez. 2004. 
. Globalización y Finanzas: circuitos de la economía urbana en la ciudad. In: Seminário Internacional de la RII, 10.0, 2008, Santiago de Queretaro, México, Anais..., México: Rede Iberoamericana de Investigadores sobre Globalização e Território, 2008, p. 1473-1490.

. São Paulo: Os dinamismos da pobreza. In: CARLOS, Ana Fani; OLIVEIRA, Ariovaldo U. de. Geografias de São Paulo: representação e crise da Metrópole. São Paulo: Contexto, 2004.

SINDICATO DOS MOTOCICLISTAS PROFISSIONAIS DO RS. [Notícias]. Disponível em: <http://sindimoto.com.br/portal>. Acesso em: 30 jul. 1999.

SINGER, Paul Israel. Economia solidária. Estudos Avançados, São Paulo, v. 22, n. 62, p. 288-314, abr. 2008. Disponível em: <http://www.scielo.br/scielo.php?script=sci_arttext\&pid=S010340142008000100020\&Ing =en\&nrm=iso>. Acesso em: 15 set. 2009.

Abramo, 2002. Introdução à economia solidária. São Paulo: Fundação Perseu

SOJA, Edward. Geografias Pós-modernas: a reafirmação do espaço na teoria social critica. Rio de Janeiro: Zahar, 1993.

SOUZA, Adriano Maicon et. al. A evolução histórica do cooperativismo. Maringá Management: Revista de Ciências Empresariais, v. 4, n. 1, p.35-42, jan./jun. 2007.

SOUZA, Paulo R. Empregos, salários e pobreza. São Paulo: HUCITEC; Campinas: Fundação de Desenvolvimento da UNICAMP, 1980.

SPÓSITO, Maria E. Beltrão. As cidades médias e os contextos econômicos contemporâneos. In: . (org.) Urbanização e cidades: perspectivas geográficas. Presidente Prudente: UNESP, 2001.

. Novos conteúdos nas periferias urbanas das cidades médias do Estado de São Paulo, Brasil. Investigaciones Geográficas, México, n. 54, p. 114-139, ago. 2004.

. Reestruturação Urbana e Segregação Socioespacial no Interior

Paulista. Scripta Nova - Revista Eletrócnica de Geografia y Ciências Sociales. Barcelona, v. XI, n. 245 (11), ago. 2007. Disponível em: <http://www.ub.es/geocrit/sn/sn-24511.htm>. Acesso em: 15 jun. 2009.

et. al. O estudo das Cidades Médias Brasileiras: uma proposta metodológica. In: . (org). Cidades Médias: espaços em transição. São Paulo: Expressão Popular, 2007. 
TABELA de Agroindústrias. Instituto de Tecnologia do Paraná. Curitiba: TECPAR, 2007. Disponível em: < http://www.tecpar.br/paranaagroindustrial/AtivTecn/TabelaAgroindústrias. htm>. Acesso em: 02 mar. 2008.

TAVARES, José Humberto. Aglomeração urbana de Londrina: integração territorial e intensificação de fluxos. 2001. $243 \mathrm{f}$. Dissertação (Mestrado em Geografia Humana) - Faculdade de Ciências e Tecnologia, UNESP, Presidente Prudente.

THEODORO, Mário. As bases da política de apoio ao setor informal no Brasil. IPEA - Textos para Discussão, Brasília, n. 762, p. 1-19, 2000. Disponível em: <http://www.ipea.gov.br>. Acesso em: 28 maio 2007.

TOKMAN, Vitor. An exploration into the nature of informal-formal sector relationships. World Development, v. 6, n. 9/10, p. $1065-1075$, set./out. 1978.

TOMAZI, Nelson Dácio. Norte do Paraná: história e fantasmagorias. 1997. 338 f. Tese (Doutorado em História) - Departamento de História, Universidade Federal do Paraná, Curitiba, 1997.

ULYSSEA, Gabriel. Informalidade no mercado de trabalho brasileiro: uma resenha da literatura. Revista de Economia Política, São Paulo, v. 26, n. 4, p. 596-618, out./dez. 2006.

YAMAKI, Humberto. Iconografia londrinense. Londrina: Humanidades, 2003.

YAZIGI, Eduardo. 0 mundo das calçadas. São Paulo: Humanitas, 2000.

ZANATTA, Marcos. Comércio ambulante: emissão de licença é suspensa. Folha de Londrina, Londrina, 20 jun. 1999, cidades. Disponível em <http://www.bonde.com.br/folha/folhad.php>, Acesso em 18 jul. 2008.

ZUCKER, Maria de Lourdes M. A industrialização de Londrina (19801988). 1989. 115 f. Monografia (Bacharelado em Geografia) Departamento de Geociências, Universidade Estadual de Londrina, Londrina. 


\section{ANEXO - QUESTIONÁRIOS}




\section{QUESTIONÁRIO 1 \\ PEQUENOS COMERCIANTES PROPRIETÁRIOS \\ DE ESTABELECIMENTOS DO CAMELÓDROMO CENTRAL}

IDENTIFICAÇÃO E RESIDÊNCIA

1) NOME

SEXO ( ) HOMEM ( ) MULHER

2) DATA DE NASCIMENTO

'

3) ESTADO CIVIL

( ) CASADO (A) ( ) SOLTEIRO (A) ( ) OUTROS

4) NASCEU EM

( ) LONDRINA

( ) OUTRO MUNCIPIO - QUAL?

UF

5) MUNICÍPIO DE RESIDÊNCIA

( ) LONDRINA ( ) OUTRO MUNICÍPIO - QUAL?

BAIRRO e RUA

6) HÁ QUANTO TEMPO RESIDE NESSE MUNICÍPIO?

( ) Menos de 1 ano ( ) 1 a 2 anos ( ) 2 a 3 anos ( ) 3 a 5 anos ( ) 5 a 10 anos ( ) 10 a 15 anos

( ) 15 a 20 anos ( ) mais de 20 anos ( ) Sempre Morou em Londrina

7) RESIDE EM

( ) CASA PRÓPRIA ( ) ALUGADA ( ) COM OS PAIS OU PARENTES （ ) OUTROS

8) POSSUI

\section{TELEVISÃO}

( ) SIM ( ) NÃO

REFRIGERADOR

( ) SIM ( ) NÃO

DVD

( ) SIM ( ) NÃO

TELEFONE FIXO

( ) SIM ( ) NÃO

TELELEFONE CELULAR

( ) SIM ( ) NÃO

9) ESCOLARIDADE

( ) FUNDAMENTAL ATÉ 4a SÉRIE

( ) MÉDIO INCOMPLETO

( ) SUPERIOR INCOMPLETO EM

\section{MICROCOMPUTADOR}

( ) SIM ( ) NÃO

ACESSO A INTERNET

( ) SIM ( ) NÃO ( ) BANDA LARGA

AUTOMÓVEL

( )SIM ( )NÃO ANO _ T TIPO

\section{MOTOCICLETA}

( )SIM ( )NÃO ANO _ _ TIPO EM EM ESCOLA ( ) PUBLICA ( ) PARTICULAR

10) ESTÁ ESTUDANDO ATUALMENTE?

( )SIM ( )NÃO

( )FUNDAMENTAL ( )MÉDIO ( )SUPERIOR ( ) OUTROS

11) COMO SE DESLOCA PARA O TRABALHO?

( )ONIBUS ( )AUTOMÓVEL PARTICULAR ( ) A PÉ ( )BICICLETA ( )MOTO 
CARACTERÍSTICAS DOS TRABALHADORES

12) VOCE É PROPRIETÁRIO DO NEGÓCIO?

( ) SIM ( ) NÃO

13) VOCE TEM REGISTRO COMO AUTÔNOMO

( ) SIM ( )NÃO

14) VOCE RECOLHE REGULARMENTE AS TAXAS DO INSS PARA APOSENTADORIA

( ) SIM ( ) NÃO

15) HÁ OUTROS SÓCIOS?

( ) SIM ( ) NÃO SE SIM QUANTOS

16) ALÉM DE VOCÊ, QUANTAS PESSOAS TRABALHAM NESTE ESTABELECIMENTO?

( ) 1 ( ) 2 ( ) 3 ( ) 4 ( ) 5 ( ) 6 ( ) 7 ( ) 8 ( ) 9 ( ) 10 ( ) Mais de 10

17) ELAS TEM REGISTRO NA CARTEIRA DE TRABALHO?

( ) SIM ( ) NÃO

18) HÁ QUANTO TEMPO TRABALHA NESTE ESTABELECIMENTO?

19) HÁ QUANTO TEMPO TABALHA NESSA ATIVIDADE?

20) QUAL SEU HORÁRIO DE TRABALHO? INDICAR HORÁRIO DE ALMOÇO E INTERVALOS

21) QUANTOS DIAS POR SEMANA?

22) QUAIS OS HORÁRIOS DE TRABALHO DAS OUTRAS PESSOAS? INDICAR HORÁRIO DE ALMOÇO

23) QUANTOS DIAS POR SEMANA?

24) VOCE TEM OUTRA ATIVIDADE?

( ) SIM ( ) NÃO SE SIM QUAL

25) EM QUE OUTRAS ATIVIDADES VOCE JÁ TRABALHOU?

26) VOCE JÁ TRABALHOU COM CARTEIRA ASSINADA?

( ) SIM ( ) NÃO SE SIM EM QUAL ATIVIDADE E POR QUÊ SAIU?

27) COMO VOCE COMEÇOU O SEU NEGÓCIO AQUI NO CAMELÓDROMO?

28) QUAL É APROXIMADAMENTE (OU EM MÉDIA) SUA RENDA MENSAL 


\section{CARACTERÍSTICAS DO ESTABELECIMENTO}

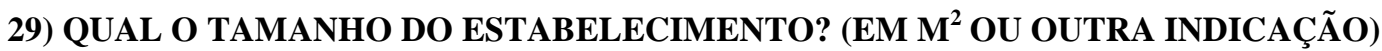

30) VOCE PAGA ALUGUEL DO ESTABELECIMENTO

( ) SIM ( ) NÃO

SE SIM QUAL O VALOR

31) VOCE PAGA CONDOMINIO?

( ) SIM ( )NÃO

SE SIM QUAL O VALOR

32) O ESTABELECIMENTO DISPÕE DE:

TELEFONE FIXO

( ) SIM ( ) NÃO

MÁQUINAS DE CARTÃO DE DÉBITO

( ) SIM ( ) NÃO

SE SIM QUAIS BANDEIRAS

MÁQUINAS DE CARTÃO DE CRÉDITO （） SIM （） NÃO

SE SIM QUAIS BANDEIRAS

COMPUTADOR

( ) SIM ( ) NÃO

ACESSO A INTENET

( ) SIM ( ) NÃO

33) A LOCALIZAÇÃO DO ESTABELECIMENTO É SATISFATÓRIA?

( ) SIM ( ) NÃO

34) O ESTABELECIMENTO UTILIZA SERVIÇOS DE OUTRAS EMPRESAS? POR EXEMPLO ENTREGAS DE MOTO, TRANSPORTADORAS, CONTADORES, DESPACHANTES, ETC.? ( ) SIM ( ) NÃO SE SIM QUAIS?

35) QUAIS SÃO OS PRINCIPAIS CONCORRENTES DESTE ESTABELECIMENTO?

36) O ESTABELECIMENTO FAZ ALGUM TIPO DE DIVULGAÇÃO, PROPAGANDA OU ANUNCIO?

( ) SIM ( ) NÃO SE SIM QUAIS 
CARACTERÍSTICAS DA ATIVIDADE

37) VOCE ADQUIRE AS MERCADORIAS QUE VENDE NO ESTABELECIMENTO EM LONDRINA?

( ) SIM ( ) NÃO

SE NÃO, INDICAR O LOCAL DE PROCEDENCIA

38) VOCE COMPRA AS MERCADORIAS DA LOJA EM ATACADISTAS?

( ) SIM ( ) NÃO

SE SIM, DE QUAIS ATACADISTAS E EM QUE MUNICIPIO SE LOCALIZAM?

39) VOCE UTILIZA TELEFONE PARA VENDER AS MERCADORIAS, RECEBER PEDIDOS?

( ) SIM, FIXO NO ESTABELECIMENTO ( ) SIM, FIXO RESIDENCIAL （ ）SIM, CELULAR

( ) NÃO

40) VOCE COSTUMA PAGAR AS COMPRAS DE MERCADORIAS PARA O ESTABELECIMENTO

( ) A VISTA ( ) A PRAZO ( ) CONSIGNADAS ( ) OUTROS

41) VOCE UTILIZA COMO MEIO DE PAGAMENTO DAS COMPRAS DE MERCADORIAS PARA LOJA

( ) CHEQUE A VISTA

( ) CHEQUE PRE-DATADO

( ) DINHEIRO

( ) CARTÕES DE CREDITO (VENCIMENTO)

( ) CARTÕES DE DÉBITO

( ) NOTAS PROMISSÓRIAS

( ) OUTROS

42) VOCE RECEBE PAGAMENTOS NA FORMA DE

( ) CHEQUE

( ) DINHEIRO

( ) CARTÕES DE DÉBITO

( ) CARTÕES DE CRÉDITO (VENCIMENTO)

( ) FIADO

( ) TICKETS DE ALIMENTAÇÃO

( ) OUTROS

43) QUAL A FORMA DE PAGAMENTO MAIS FREQUENTEMENTE USADA PELOS COMPRADORES?

44) QUAL É, EM MÉDIA, O FATURAMENTO BRUTO DA LOJA NO MÊS?

45) OS COMPRADORES QUE VÊM AO ESTABELECIMENTO SÃO NA MAIORIA?

( ) HOMENS ( ) MULHERES

( ) JOVENS ( ) ADULTOS ( ) IDOSOS

( ) BAIXA RENDA ( ) MÉDIA RENDA ( )ALTA RENDA

46) A MAIORIA DOS COMPRADORES QUE COMPRAM AQUI NA LOJA MORAM EM:

( ) LONDRINA ( ) OUTROS MUNICÍPIOS - QUAIS

47) SEU ESTABELECIMENTO É PROCURADO POR CLIENTES DE OUTROS MUNICIPIOS?

( ) SIM ( ) NÃO - SE SIM QUAIS 
48) COMO ESCOLHE E COMO DECIDE VENDER NOVOS PRODUTOS?

49) VOCE FAZ ALGUM TIPO DE ANOTAÇÃO (REGISTRO) DAS VENDAS (MOVIMENTO), COMPRAS E OUTRAS DESPESAS DO ESTABELECIMENTO?

( ) SIM ( ) NÃO SE SIM, COMO?

50) O ESTABELECIMENTO UTILIZA SERVIÇOS BANCÁRIOS?

( ) SIM ( ) NÃO SE SIM, QUAIS?

51) QUANDO COMEÇOU COM A SUA LOJA AQUI NO CAMELÓDROMO, UTILIZOU ALGUM TIPO DE CRÉDITO PARA O NEGÓCIO COM BANCOS, FINANCEIRAS, AMIGOS, VIZINHOS, PARENTES ETC..

( ) SIM ( ) NÃO

SE SIM COM QUEM?

52) ATUALMENTE VOCE UTILIZA ALGUM TIPO DE CRÉDITO COM BANCOS, FINANCEIRAS, AMIGOS, VIZINHOS OU PARENTES, PARA O SEU NEGÓCIO AQUI NO CAMELÓDROMO?

( ) SIM ( ) NÃO SE SIM, COM QUEM?

\section{OUTRAS OBSERVAÇÕES}




\section{QUESTIONÁRIO 2 \\ FUNCIONÁRIOS DOS ESTABELECIMENTOS \\ DO CAMELÓDROMO CENTRAL}

IDENTIFICAÇÃO E RESIDÊNCIA

1) NOME

SEXO ( ) HOMEM ( ) MULHER

2) DATA DE NASCIMENTO

I__

3) ESTADO CIVIL

( ) CASADO (A) ( ) SOLTEIRO (A) ( ) OUTROS

4) NASCEU EM

( ) LONDRINA

( ) OUTRO MUNCIPIO - QUAL?

UF

5) MUNICÍPIO DE RESIDÊNCIA

( ) LONDRINA ( ) OUTRO MUNICÍPIO - QUAL?

BAIRRO e RUA

6) HÁ QUANTO TEMPO RESIDE NESSE MUNICÍPIO?

( ) Menos de 1 ano ( ) 1 a 2 anos ( ) 2 a 3 anos ( ) 3 a 5 anos ( ) 5 a 10 anos ( ) 10 a 15 anos ( ) 15 a 20 anos ( ) mais de 20 anos

7) RESIDE EM

( ) CASA PRÓPRIA ( ) ALUGADA ( ) COM OS PAIS OU PARENTES （ ) OUTROS

8) POSSUI

\section{TELEVISÃO}

( ) SIM ( ) NÃO

REFRIGERADOR

( ) SIM ( ) NÃO

DVD

( ) SIM ( ) NÃO

TELEFONE FIXO

( ) SIM ( ) NÃO

TELELEFONE CELULAR

( ) SIM ( ) NÃO

9) ESCOLARIDADE

( ) FUNDAMENTAL ATÉ $4^{a}$ SÉRIE

( ) MÉDIO INCOMPLETO

( ) SUPERIOR INCOMPLETO EM EM

\section{MICROCOMPUTADOR}

( ) SIM ( ) NÃO

\section{ACESSO A INTERNET}

( ) SIM ( ) NÃO ( ) BANDA LARGA

AUTOMÓVEL

( )SIM ( )NÃO ANO TIPO

\section{MOTOCICLETA}

( )SIM ( )NÃO ANO TIPO

10) ESTÁ ESTUDANDO ATUALMENTE?

( )SIM ( )NÃO

( )FUNDAMENTAL ( )MÉDIO ( )SUPERIOR ( ) OUTROS

11) COMO SE DESLOCA PARA O TRABALHO?

( )ONIBUS ( )AUTOMÓVEL PARTICULAR ( ) A PÉ ( )BICICLETA ( )MOTO 
CARACTERÍSTICAS DOS TRABALHADORES

12) HÁ QUANTO TEMPO TRABALHA AQUI NO CAMELÓDROMO?

13) HÁ QUANTO TEMPO TABALHA NESSA ATIVIDADE? (VENDAS)

14) VOCE É REGISTRADO (A) NA CARTEIRA DE TRABALHO?

( ) SIM ( ) NÃO

15) VOCE TEM REGISTRO COMO AUTONOMO

( ) SIM ( )NÃO

SE SIM, VOCE RECOLHE REGULARMENTE AS TAXAS DO INSS PARA APOSENTADORIA ( ) SIM ( )NÃO

16) VOCE TEM UM SALÁRIO FIXO?

( ) SIM ( )NÃO

VERIFICAR SE GANHA POR COMISSÃO

17) QUANTAS PESSOAS TRABALHAM NESTE ESTABELECIMENTO?

18 QUAL SEU HORÁRIO DE TRABALHO? INDICAR HORÁRIO DE ALMOÇO E INTERVALOS

19) QUANTOS DIAS POR SEMANA?

20) VOCE TEM OUTRA ATIVIDADE?

( ) SIM ( ) NÃO

SE SIM QUAL?

21) QUAL É APROXIMADAMENTE (OU EM MÉDIA) SUA RENDA MENSAL 
CARACTERÍSTICAS DO ESTABELECIMENTO

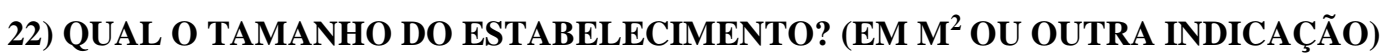

23) O PROPRIETÁRIO PAGA ALUGUEL DO ESTABELECIMENTO?

( ) SIM ( ) NÃO

SE SIM QUAL O VALOR

24) O ESTABELECIMENTO DISPÕE DE:

TELEFONE FIXO

MÁQUINAS DE CARTÃO DE DÉBITO

( ) SIM ( ) NÃO

SE SIM QUAIS BANDEIRAS

MÁQUINAS DE CARTÃO DE CRÉDITO ( ) SIM ( ) NÃO

SE SIM QUAIS BANDEIRAS

COMPUTADOR

( ) SIM ( ) NÃO

ACESSO A INTERNET

( ) SIM ( ) NÃO

25) O ESTABELECIMENTO É REGISTRADO COMO MICROEMPRESA?

( ) SIM ( ) NÃO ( ) OUTROS

26) A LOCALIZAÇÃO DO ESTABELECIMENTO É SATISFATÓRIA?

( ) SIM ( ) NÃO

27) O ESTABELECIMENTO UTILIZA SERVIÇOS DE OUTRAS EMPRESAS? POR EXEMPLO ENTREGAS DE MOTO, TRANSPORTADORAS, CONTADORES, DESPACHANTES, ETC..

( ) SIM ( ) NÃO SE SIM QUAIS?

28) O ESTABELECIMENTO FAZ ALGUM TIPO DE DIVULGAÇÃO, PROPAGANDA OU ANUNCIO?

( ) SIM ( ) NÃO SE SIM QUAIS 
CARACTERISTICAS DA ATIVIDADE

29) AS MERCADORIAS QUE SÃO VENDIDAS NO ESTABELECIMENTO VÊM DE LONDRINA?

( ) SIM ( ) NÃO

SE NÃO INDICAR O LOCAL DE PROCEDENCIA

30) VOCE AJUDA A FAZER AS COMPRAS PARA O ESTABELECIMENTO?

( ) SIM ( ) NÃO

SE SIM PERGUNTAR

30.1) AS COMPRAS DE MERCADORIAS SÃO FEITAS EM ATACADISTAS?

( ) SIM ( ) NÃO

SE SIM DE QUAIS ATACADISTAS E EM QUE MUNICIPIOS SE LOCALIZAM?

30.2) AS COMPRAS DE MERCADORIAS SÃO FEITAS DIRETAMENTE COM ALGUM

FABRICANTE?

( ) SIM ( ) NÃO

SE SIM, QUAIS E ONDE SE LOCALIZAM?

30.3) AS COMPRAS DE MERCADORIAS PARA O ESTABELECIMENTO SÃO PAGAS

( ) A VISTA ( ) A PRAZO ( ) CONSIGNADAS ( ) OUTROS

30.4) AS COMPRAS DE MERCADORIAS SÃO PAGAS POR MEIO DE

( ) CHEQUE PRE-DATADO

( ) DINHEIRO

( ) CARTÕES DE CREDITO (VENCIMENTO)

( ) CARTÕES DE DÉBITO

( ) NOTAS PROMISSÓRIAS

( ) OUTROS

31) CHEGAM MERCADORIAS NOVAS NO ESTABELECIMENTO:

( ) A CADA SEMANA ( ) A CADA 15 DIAS ( ) MENSALMENTE

32) O ESTABELECIMENTO VENDE MERCADORIAS UTILIZANDO O TELEFONE, POR EXEMPLO, PARA RECEBER PEDIDOS?

( ) SIM FIXO ( ) SIM CELULAR ( ) NÃO

33) AQUI NO ESTABELECIMENTO OS CLIENTES UTILIZAM NOS SEUS PAGAMENTOS:

( ) CHEQUE

( ) DINHEIRO

( ) CARTÕES DE DÉBITO

( ) CARTÕES DE CRÉDITO (VENCIMENTO)

( ) FIADO

( ) TICKETS DE ALIMENTAÇÃO

( ) OUTROS

34) QUAL A FORMA DE PAGAMENTO MAIS FREQUENTEMENTE USADA PELOS COMPRADORES? 
35) QUAL É APROXIMADAMENTE O FATURAMENTO BRUTO MENSAL DO ESTABELECIMENTO?

36) OS COMPRADORES QUE VEM AO ESTABELECIMENTO NA SUA MAIORIA VÊM DE AS PESSOAS QUE COMPRAM NO ESTABELECIMENTO VÊM DE:

( ) LONDRINA ( ) OUTRO MUNICÍPIO - QUAL

37) O ESTABELECIMENTO É PROCURADO POR CLIENTES DE OUTROS MUNICIPIOS?

( ) SIM ( ) NÃO - SE SIM

QUAIS?

38) COMO SÃO ANOTADAS (REGISTRADAS) AS VENDAS QUE VOCE FAZ NO DIA?

39) O ESTABELECIMENTO UTILIZA SERVIÇOS BANCÁRIOS?

( ) SIM ( ) NÃO SE SIM, QUAIS?

40) ATUALMENTE A LOJA UTILIZA ALGUM TIPO DE CRÉDITO COM BANCOS, FINANCEIRAS, AMIGOS, VIZINHOS OU PARENTES, PARA O SEU NEGÓCIO AQUI NO CAMELÓDROMO?

( ) SIM ( ) NÃO

SE SIM, COM QUEM?

OUTRAS OBSERVAÇÕES 


\section{QUESTIONÁRIO 3 \\ CENTRAIS DE CHAMADAS DO SERVIÇO DE MOTO TÁXI \\ IDENTIFICAÇÃO DA EMPRESA E DO INFORMANTE}

1) NOME DA EMPRESA

2) LOCALIZAÇÃO DA CENTRAL

RUA E BAIRRO

3) A CENTRAL POSSUI FILAIS, POSTOS DE ATENDIMENTO OU ALGUM TIPO INSTALAÇÃO EM OUTRA LOCALIZAÇÃO?

( ) SIM ( ) NÃO SE SIM, QUANTAS E ONDE? (RUA BAIRRO)

4) HÁ OUTRAS CENTRAIS QUE PERTENCEM AO MESMO PROPRIETÁRIO?

( ) SIM ( ) NÃO QUANTAS? _ QUAIS?

LOCALIZAÇÃO DAS OUTRAS CENTRAIS (RUA E BAIRRO)

5) NOME DO RESPONSÁVEL PELAS INFORMAÇÕES

SEXO DO RESPONSÁVEL ( ) HOMEM ( )MULHER

6) DATA DE NASCIMENTO I_

7) É PROPRIETÁRIO DA EMPRESA OU SÓCIO?

( ) SIM ( ) NÃO

SE NÃO INDICAR A POSIÇÃO NA EMPRESA 
CARACTERÍSTICAS DA EMPRESA

8) HÁ QUANTO TEMPO ESSA CENTRAL EXISTE?

9) COMO ESSA CENTRAL FOI CRIADA?

10) A CENTRAL ESTÁ REGISTRADA COMO?

( ) MICRO ( ) PEQUENA ( ) MÉDIA ( ) GRANDE

11) QUANTOS FUNCIONÁRIOS A CENTRAL TEM?

11) DESSE TOTAL DE FUNCIONÁRIOS, QUANTOS TRABALHAM NA ADMINISTRAÇÃO E PARTE BUROCRÁTICA?

12) DESSE TOTAL DE FUNCIONÁRIOS QUANTOS SÃO MOTOTAXISTAS?

14) COMO É O VÍNCULO DE TRABALHO ENTRE A CENTRAL E OS MOTOTAXISTAS?

15) QUAL É APROXIMADAMENTE O FATURAMENTO LIQUIDO MENSAL DA CENTRAL?

16) QUAIS SÃO AS MAIORES DESPESAS DA CENTRAL?

17) A CENTRAL UTILIZA OS SERVIÇOS DE OUTRAS EMPRESAS OU PROFISSIONAIS? (EX: ESCRITÓRIO DE CONTABILIDADE, SEGURADORAS, OFICINAS DE CONCERTOS, GRÁFICA QUE IMPRIME CARTÕES, WEB DESIGNER PARA SITE INTERNET, ETC.)

18) COMO A CENTRAL DIVULGA OS SEUS SERVIÇOS? (CARTÕES, LISTA TELEFONICA, JORNAL DE BAIRRO, INTERNET, ETC.)

19) A CENTRAL DISPÕEM E UTILIZA EM SUA ATIVIDADE DE:

( ) TELEFONE FIXO SIMPLES

( ) CENTRAL TELEFONICA

( ) FAX

( ) SERVIÇO DE TELEFONES CELULARES DE TIPO EMPRESARIAL

( ) INTERNET - SE SIM ( ) DISCADA （）BANDA LARGA ( ) OUTROS

( ) EQUIPAMENTO DE RÁDIO

( ) OUTROS 
CARCTERIZAÇÃO DO SERVIÇO

20) QUE TIPO DE EMPRESA CONTRATA OS SERVIÇOS DESTA CENTRAL?

21) EM QUE MUNICÍPIOS SE LOCALIZAM AS EMPRESAS ATENDIDAS?

22) QUE TIPO DE EMPRESA É CLIENTE MAIS VANTAJOSO PARA A CENTRAL E POR QUÊ

24) QUAIS OS TIPOS DE VIAGENS MAIS VANTAJOSAS PARA O MOTOTAXISTA E POR QUÊ?

25) QUAL BAIRRO OU LOCAL DA CIDADE:

DE ONDE A CENTRAL RECEBE UM MAIOR NÚMERO DE CHAMADOS?

PARA ONDE REALIZA MAIOR NÚMERO DE VIAGENS?

26) A CENTRAL RECEBE CHAMADOS PARA FAZER VIAGENS DE LONDRINA PARA OUTROS MUNICÍPIOS?

( ) SIM ( ) NÃO

SE SIM, INDIQUE QUAIS MUNICÍPIOS E QUE TIPO VIAGENS, SE É PARA PASSAGEIROS, ENTREGAS, OU OUTROS SERVIÇOS, O TIPO DE TAXA QUE É COBRADA E A FREQUENCIA (DIÁRIA, SEMANAL OU MENSAL)

27) A CENTRAL RECEBE CHAMADOS PARA FAZER VIAGENS DE OUTROS MUNICÍPIOS PARA LONDRINA?

( ) SIM ( ) NÃO

SE SIM, INDIQUE QUAIS MUNICÍPIOS E QUE TIPO VIAGENS, SE É PARA PASSAGEIROS, ENTREGAS, OU OUTROS SERVIÇOS, O TIPO DE TAXA QUE É COBRADA E A FREQUENCIA (DIÁRIA, SEMANAL MENSAL)

28) A CENTRAL ORGANIZA OS TRAJETOS DOS ENTREGADORES?

( ) SIM ( ) NÃO

SE SIM INDICAR COMO

29) QUAIS SÃO SEUS PRINCIPAIS CONCORRENTES?

30) QUAIS SÃO AS PRINCIPAIS DIFICULDADES QUE A CENTRAL ENFRENTA? 
31) QUAIS SÃO OS PONTOS POSITIVOS E MAIS PROMISSORES DO MERCADO PARA ESSA ATIVIDADE?

32) A CENTRAL É FISCALIZADA? POR QUEM?

33) QUE TIPO DE IMPOSTOS E TAXAS A CENTRAL RECOLHE?

34) A CENTRAL UTILIZA SERVIÇOS BANCÁRIOS?

( ) SIM ( ) NÃO

QUAIS?

OUTRAS OBSERVAÇÕES 


\section{QUESTIONÁRIO 4}

MOTOTAXISTAS

IDENTIFICAÇÃO E RESIDÊNCIA

1) NOME

SEXO ( ) HOMEM ( )MULHER

2) DATA DE NASCIMENTO

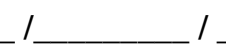

3) ESTADO CIVIL

( ) CASADO (A) ( ) SOLTEIRO (A) ( ) OUTROS

4) NASCEU EM

( ) LONDRINA

( ) OUTRO MUNCIPIO - QUAL?

$\mathrm{UF}$

5) MUNICIPIO DE RESIDENCIA

( ) LONDRINA ( ) OUTRO MUNICÍPIO - QUAL?

BAIRRO e RUA

6) HÁ QUANTO TEMPO RESIDE NESSE MUNICÍPIO?

( ) Menos de 1 ano ( ) 1 a 2 anos ( ) 2 a 3 anos ( ) 3 a 5 anos ( ) 5 a 10 anos ( ) 10 a 15 anos

( ) 15 a 20 anos ( ) mais de 20 anos

7) RESIDE EM

( ) CASA PRÓPRIA ( ) ALUGADA ( )COM OS PAIS OU PARENTES OUTROS

8) POSSUI

TELEVISÃO

( ) SIM ( ) NÃO

REFRIGERADOR

( ) SIM ( ) NÃO

DVD

( ) SIM ( ) NÃO

TELEFONE FIXO

( ) SIM ( ) NÃO

TELELEFONE CELULAR

( ) SIM ( ) NÃO

9) ESCOLARIDADE

( ) FUNDAMENTAL ATÉ 4 a SÉRIE

( ) MÉDIO INCOMPLETO

( ) SUPERIOR INCOMPLETO EM

\section{MICROCOMPUTADOR}

( ) SIM ( ) NÃO

\section{ACESSO A INTERNET}

( ) SIM ( ) NÃO ( ) BANDA LARGA

AUTOMÓVEL ( )SIM ( )NÃO ANO _ _ TIPO

MOTOCICLETA

( )SIM ( )NÃO ANO TIPO EM ESCOLA ( ) PUBLICA ( ) PARTICULAR

10) ESTÁ ESTUDANDO ATUALMENTE?

( ) SIM ( )NÃO

( )FUNDAMENTAL ( )MÉDIO ( )SUPERIOR ( ) OUTROS 


\section{ATUAÇÃO PROFISSIONAL}

11) QUAL É A SUA ATIVIDADE ATUAL?

12) HÁ QUANTO TEMPO TABALHA NESSA ATIVIDADE?

13) VOCE TEM OUTRA ATIVIDADE?

( )SIM ( ) NÃO QUAL?

14) QUAL A SUA RENDA MENSAL ATUAL? (APROXIMADAMENTE)

15) EM QUE OUTRAS ATIVIDADES VOCE JÁ TRABALHOU?

16) JÁ TRABALHOU COM CARTEIRA DE TRABALHO REGISTRADA ANTES DA ATIVIDADE ATUAL?

( )SIM ( ) NÃO

17) VOCE TRABALHA PARA UMA ÚNICA CENTRAL DE CHAMADAS?

( ) SIM ( ) NÃO SE NÃO PARA QUANTAS

18) ONDE SE LOCALIZA(M) ESSA(S) EMPRESA(S)?

RUA e BAIRRO

19) COMO É O CONTRATO COM A CENTRAL DE CHAMADAS?

20) ONDE VOCE ESPERA PELAS SUAS CHAMADAS? POR QUÊ?

21) COMO É ORGANIZADA A COBRANÇA DAS CHAMADAS? EXISTE ALGUM TIPO DE APARELHO E TABELA COMO NOS TAXIS?

22) QUANTAS VIAGENS VOCE REALIZA, EM MÉDIA, POR DIA?

23) FALE SOBRE A DURAÇÃO DAS VIAGENS E OS PRINCIPAIS DESTINOS DESSAS VIAGENS?

24) QUAIS OS TIPOS DE VIAGENS MAIS VANTAJOSAS PARA O MOTO TAXISTA E POR QUÊ?

25) POR QUAIS CORREDORES DE TRAFEGO, AVENIDAS E RUAS VOCE CIRCULA COM MAIS FREQUENCIA E POR QUE? 
26) HÁ ALGUM BAIRRO OU LOCAL DA CIDADE DO QUAL VOCE RECEBE UM MAIOR NUMERO DE CHAMADOS E REALIZA UM MAIOR NUMERO DE VIAGENS?

27) VOCE RECEBE CHAMADOS PARA FAZER VIAGENS DE LONDRINA PARA OUTROS MUNICIPIOS?

( ) SIM ( ) NÃO

SE SIM, INDIQUE QUAIS MUNICIPIOS E QUE TIPO VIAGENS, SE É PARA PASSAGEIROS, ENTREGAS, OU OUTROS SERVIÇOS, O TIPO DE TAXA QUE É COBRADA E A FREQUENCIA DAS VIAGENS (DIÁRIA, SEMANAL OU MENSAL)

28) QUAL SEU HORÁRIO DE TRABALHO? (INDICAR HORÁRIO DE ALMOÇO E INTERVALOS)

29) QUANTOS DIAS POR SEMANA?

30) ATUALMENTE SUA ATIVIDADE ESTÁ REGISTRADA NA CARTEIRA DE TRABALHO? ( ) SIM ( ) NÃO

31) VOCE TEM REGISTRO COMO AUTONOMO?

( ) SIM ( )NÃO

SE NÃO INDICAR SE POSSUI ALGUM OUTRO TIPO DE REGISTRO EM ÓRGÃO PÚBLICO

32) VOCE RECOLHE REGULARMENTE AS TAXAS DO INSS?

( )SIM ( )NÃO

33) POSSUI SEGURO DA MOTO, ALÉM DO SEGURO OBRIGATÓRIO E DO SEGURO DA CMTU? ( )SIM ( ) NÃO

34) POSSUI SEGURO DE ACIDENTES PESSOAIS?

( )SIM ( ) NÃO

35) EM CASO DE DOENÇA OU ACIDENTE COMO FICAM OS SEUS RENDIMENTOS? 
CARACTERÍSTICAS DA ATIVIDADE

36) VOCE É O PROPRIETÁRIO DA MOTO?

( ) SIM ( ) NÃO (SE NÃO ESPECIFICAR)

SE SIM - COMO A ADQUIRIU PRIMEIRA MOTO E COMO ADQUIRIU A MOTO ATUAL?

37) A MOTO É FINANCIADA?

( ) SIM ( ) NÃO VALOR DA

PRESTAÇÃO

38) QUAIS SÃO SUAS DESPESAS PARA EXERCER ESSA ATIVIDADE?

39) EXISTEM NA CIDADE OFICINAS OU OUTROS SERVIÇOS QUE DÃO PREFERENCIA PARA ATENDER OS MOTO TAXISTAS E MOTO ENTREGADORES?

40) QUE TIPO DE PESSOA UTILIZA COM MAIS FREQUENCIA O SERVIÇO DO MOTO TAXISTA?

( ) HOMENS ( ) MULHERES

( ) JOVENS ( ) ADULTOS ( ) IDOSOS

( ) BAIXA RENDA ( ) MÉDIA RENDA ( ) ALTA RENDA

41) EM QUE HORÁRIOS VOCE RECEBE UM MAIOR NUMERO DE CHAMADAS?

42) QUE TIPO DE NECESSIDADES FAZEM COM QUE OS USUÁRIOS CHAMEM O MOTO TAXISTA?

\section{COM QUE FREQUENCIA?}

43) QUAIS FERRAMENTAS VOCE UTILIZA DIARIAMENTE PARA SUA ATIVIDADE?

( ) TEEFONE CELULAR

( ) TELEFONE FIXO

( ) INTERNET

( ) OUTROS

44) VOCE UTILIZA SERVIÇOS BANCÁRIOS?

45) VOCE UTILIZA OU UTILIZOU ALGUM TIPO DE CRÉDITO PARA O NEGÓCIO COM BANCOS, FINANCEIRAS, AMIGOS, VIZINHOS, PARENTES ETC.?

46) VOCE JÁ CONSEGUIU ALGUM TIPO DE FINANCIAMENTO EM BANCOS, AGENCIAS DE FINANCIAMENTO OU FINANCEIRAS? 


\section{QUESTIONÁRIO 5}

PARA MOTOBOYS

\section{IDENTIFICAÇÃO E RESIDÊNCIA}

1) NOME

SEXO ( ) HOMEM ( )MULHER

2) DATA DE NASCIMENTO

3) ESTADO CIVIL

( ) CASADO (A) ( ) SOLTEIRO (A) ( ) OUTROS

4) NASCEU EM

( ) LONDRINA

( ) OUTRO MUNCIPIO - QUAL? UF

5) MUNICÍPIO DE RESIDENCIA

( ) LONDRINA ( ) OUTRO MUNICÍPIO - QUAL?

BAIRRO e RUA

6) HÁ QUANTO TEMPO RESIDE NESSE MUNICÍPIO?
( ) Menos de 1 ano ( ) 1 a 2 anos ( ) 2 a 3 anos ( ) 3 a 5 anos ( ) 5 a 10 anos ( ) 10 a 15 anos ( ) mais de 20 anos
( ) 15 a 20 anos
7) RESIDE EM
( )CASA PRÓPRIA ( )ALUGADA （ )COM OS PAIS OU PARENTES ( ) OUTROS

8) POSSUI

TELEVISÃO

( ) SIM ( ) NÃO

MICROCOMPUTADOR

REFRIGERADOR

( ) SIM ( ) NÃO

( ) SIM ( ) NÃO ACESSO A INTERNET

DVD

( ) SIM （ ) NÃO

( ) SIM ( ) NÃO

( ) BANDA LARGA

TELEFONE FIXO

( ) SIM ( ) NÃO

AUTOMÓVEL

( )SIM ( )NÃO ANO ___ TIPO

MOTOCICLETA

( )SIM ( )NÃO ANO TIPO

\section{TELELEFONE CELULAR}

( ) SIM ( ) NÃO

9) ESCOLARIDADE

( ) FUNDAMENTAL ATÉ $4^{\mathrm{a}}$ SÉRIE （ ） FUNDAMENTAL ATÉ 8 ${ }^{\mathrm{a}}$ SÉRIE

( ) MÉDIO INCOMPLETO

( ) MÉDIO COMPLETO

( ) SUPERIOR INCOMPLETO EM

( ) SUPERIOR COMPLETO

EM EM ESCOLA ( ) PUBLICA ( ) PARTICULAR

10) ESTÁ ESTUDANDO ATUALMENTE?

( ) SIM ( ) NÃO

( ) FUNDAMENTAL ( ) MÉDIO ( ) SUPERIOR ( ) OUTROS 
ATUAÇÃO PROFISSIONAL

11) HÁ QUANTO TEMPO TABALHA COMO MOTO BOY?

12) VOCE TEM OUTRA ATIVIDADE (ALÉM DE SER MOTO BOY)?

( ) SIM ( ) NÃO

QUAL?

13) EM QUANTAS EMPRESAS (LUGARES VOCE TRABALHA?)

14) EM QUE OUTRAS ATIVIDADES VOCE JÁ TRABALHOU?

15) ALGUMAS DAS EMPRESAS EM QUE TRABALHA VOCE TEM A CARTEIRA DE TRABALHO ASSINADA (REGISTRADA)?

( )SIM ( ) NÃO

15 A) SE NÃO COMO É O CONTRATO COM A(S) EMPRESA(S) COM AS QUAIS VOCE TEM VÍNCULO DIRETO DE TRABALHO?

16) COM QUE TIPO(S) DE EMPRESAS VOCE MANTEM VINCULO DIRETO DE TRABALHO?

( ) EMPRESA ESPECIALIZADA EM SERVIÇOS DE MOTO ENTREGADORES

( ) PIZZARIA

( ) RESTAURANTE

( ) FARMÁCIA

( ) OUTROS

17) NOME DA EMPRESA E LOCALIZAÇÃO

18) QUAL SEU HORÁRIO DE TRABALHO? (INDICAR HORÁRIO DE ALMOÇO E INTERVALOS)

19) QUANTOS DIAS POR SEMANA?

20) ALGUMA DAS EMPRESAS OFERECE BENEFÍCIOS? ( MANUTENÇÃO DA MOTO, TICKET PARA ALMOÇO, ETC.)

21) PARA QUAIS EMPRESAS VOCE PRESTA SERVIÇO COMO TERCEIRIZADO?

( ) PIZZARIA

( ) RESTAURANTE

( ) FARMÁCIA

( ) HOSPITAL

( ) BANCO

( ) LOJA DE PEÇAS PARA AUTOMOVEIS

( ) LOJA DE PEÇAS PARA CAMINHÕES

( ) LOJA DE PEÇAS PARA MOTOS

( ) LOJA DE TINTAS

( ) OUTROS

22) COMO É SEU TRABALHO (AS ENTREGAS) BREVE DESCRIÇÃO? 
23) VOCE TEM SALARIO FIXO?

( ) SIM ( ) NÃO

24) QUANTO VOCE GANHA NO MÊS?

26) EM CASO DE DOENÇA OU ACIDENTE COMO FICAM OS SEUS RENDIMENTOS? 
CARACTERÍSTICAS DA ATIVIDADE

27) VOCE É O PROPRIETÁRIO DA MOTO?

( ) SIM ( ) NÃO (SE NÃO ESPECIFICAR)

27 A) SE SIM - COMO A ADQUIRIU?

28) A MOTO É FINANCIADA?

( ) SIM ( ) NÃO VALOR DA PRESTAÇÃO

38) QUAIS SÃO SUAS DESPESAS PARA EXERCER ESSA ATIVIDADE?

29) TEM ALGUM TIPO DE NETREGA QUE VOCE PREFERE FAZER?

30) REALIZA ENTREGAS EM OUTROS MUNICÍPIOS?

( ) SIM ( ) NÃO SE SIM QUAIS?

30 A) COM QUE FREQUÊNCIA?

( ) DIARIAMENTE ( ) SEMANALMENTE ( ) MENSALMENTE ( ) RARAMENTE

30 B) QUE TIPO DE PRODUTO, DOCUMENTO, ETC VOCE LEVA PARA OUTRO MUNICIPIO? 
